
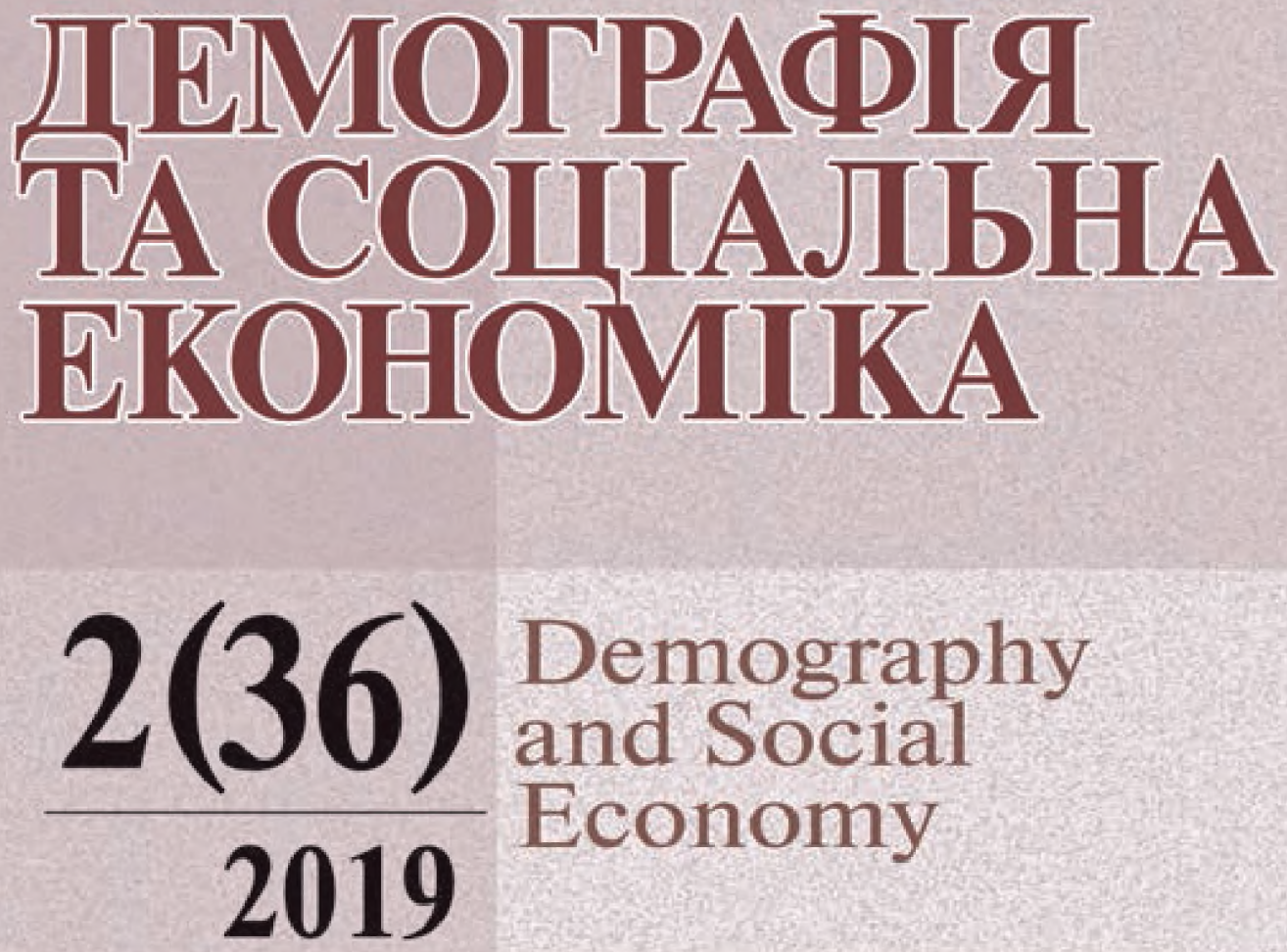

Demography and Social Economy

ERIH PLUS Index Copernicus Polish Scholarly Bibliography (PNB) Ulrich's Periodicals Directory WorldCat Google Scholar Cosmos Impact Factor CrossRef RISC EZB IBSS

Наукова періодика України Українські наукові журнали Бібліометрика української науки

\section{Демография и социальная экономика}

www.idss.org.ua 


\section{ДЕМОГРАФІЯ ТА СОЦІАЛЬНА EKOHOMIKA}

\section{2(36) DEMOGRAPHY AND SOCIAL ECONOMY}

\section{9 ДЕМОГРАФИЯ \\ И СОЦИАЛЬНАЯ ЭКОНОМИКА}

\section{ERIH PLUS}

Index Copernicus

Polish Scholarly Bibliography (PBN)

Ulrich's Periodicals Directory

WorldCat

Google Scholar

Cosmos Impact Factor

CrossRef

RISC

EZB

IBSS

Наукова періодика України (Uran Publish Servis, OJS)

Українські наукові журнали Інформаційно-аналітична система «Бібліометрика української науки» (Ranking of Scientists (Cybermetrics Lab) Національної бібліотеки

України імені В.I. Вернадського
НАУКОВИЙ ЖУРНАЛ

ВИХОДИТЬ 3 РАЗИ НА РІК

ЗАСНОВАНИЙ У ЛИСТОПАДІ 2004 РОКУ

КИЇВ

- ДЕМОГРАФІЧНІ ПРОЦЕСИ

- СОЦІАЛЬНО-ЕКОНОМІЧНІ ПРОБЛЕМИ

- ПРОФЕСІЙНА ОСВІТА, ПРАЦЯ ТА ЗАЙНЯТІСТЬ 
УДК 314(051)

https://doi.org/10.15407/dse2019.02

\section{Видавці та засновники:}

Національна академія наук

України

Інститут демографії та соціальних досліджень імені

М.В. Птухи НАН України

Свідоцтво про державну реєстрацію друкованого засобу масової інформації 12.01.2004 р. серія КВ №8304. Перереєстроване 22.06.2012 р. серія КВ №19037-7827 ПР Державною реєстраційною службою України.

32015 року журнал виходить тричі на рік (лист Міністерства юстиції України № 20679-0-33-151194 від 12.08 .2015 р. про внесення дозволу до Державного реєстру друкованих засобів масової інформації та інформаційних агентств як суб'єктів інформаційної діяльності)

Відповідно до наказу МОН України № 32 від 15.01.2018 p.

журнал «Демографія та соціальна економіка» входить до категорії В Переліку наукових фахових видань, в яких можуть публікуватися результати дисертаційних робіт на здобуття наукових ступенів доктора і кандидата наук

\section{Затверджено до друку}

та опублікування в мережі Інтернет Вченою радою Інституту демографії та соціальних досліджень ім. М.В. Птухи НАН України 14.06.2019 р. протокол № 9

Підписано до друку 01.07.2019 р.

\section{Адреса редакції:}

Україна, 01032, м. Київ,

б-р Тараса Шевченка, 60.

Тел. (044) 486-62-37,

482-17-45, 486-04-97

E-mail:j_dse@ukr.net

http://www.dse.org.ua

Формат 70×100/16.

Гарнітура Newton C.

Умов. друк. арк. 16,58.

Обл.-вид. арк. 20,40.

Тираж 170 прим.

Зам. № 5679 від 15.07.2019 р.

\section{Віддруковано}

ВД «Академперіодика»

НАН України

01004, Київ,

вул. Терешенківська, 4

Свідоцтво про внесення до Державного реєстру суб'єктів видавничої справи серії ДК № 544 від 27.07.2001

\section{РЕДАКЦІЙНА КОЛЕГІЯ}

Голова редакційної колегії: Е.М. ЛІБАНОВА -

директор Інституту демографії та соціальних досліджень (ІДСД)

ім. М.В. Птухи НАН України, акад. НАН України, д-р екон. наук, проф. Заступник голови редакційної колегії: С.І. ПИРОЖКОВ -

акад. НАН України, д-р екон. наук, проф., віце-президент НАН України

Заступник голови редакційної колегії: О.В. МАКАРОВА -

чл.-кор. НАН України, д-р екон. наук, заст. директора ІДСД

ім. М.В. Птухи НАН України

Відповідальний секретар: О.М. ГЛАДУН - чЛ.-кор. НАН України, д-р екон. наук, заст. директора ІДСД ім. М.В. Птухи НАН України

Члени редколегії: А.Л. Баланда, д-р екон. наук, проф., Бердянський університет менеджменту і бізнесу

А.Г. Вишневський, д-р екон. наук, проф., акад. РАЕН, Державний університет «Высшая школа экономики», м. Москва, РФ

O.A. Грішнова, д-р екон. наук, проф., КНУ ім. Тараса Шевченка, м. Київ, Україна H.М. Дєєва, Д-р екон. наук, проф., ІДСД ім. М.В. Птухи НАН України

Г.А. Дмитренко, д-р екон. наук, проф., Університет менеджменту освіти АПН

України, м. Київ, Україна

A.M. Сріна, д-р екон. наук, проф., ДВНЗ «КНЕУ ім. В. Гетьмана», м. Київ, Україна

T.A. Заяць, д-р екон. наук, проф., ІДСД ім. М.В. Птухи НАН України

I.C. Каленюк, д-р екон. наук, проф., Науково-дослідний інститут економічного розвитку ДВНЗ «Київський національний економічний університет ім. Вадима Гетьмана»

M.I. Карлін, д-р екон. наук, проф., Східноєвропейський національний університет ім. Лесі Українки, м. Луцьк, Україна

A.M. Колот, д-р екон. наук, проф., ДВНЗ «КНЕУ ім. В. Гетьмана», м. Київ, Україна

I.C. Кравченко, д-р екон. наук, проф., Університет банківської справи НБУ, м. Київ, Україна

I.O. Курило, Д-р екон. наук, проф. ІДСД ім. М.В. Птухи НАН України

Н.М. Левчук, д-р екон. наук, ІДСД ім. М.В. Птухи НАН України

Л.С. Лісогор, Д-р екон. наук, проф., ІДСД ім. М.В. Птухи НАН України

O.A. Малиновська, д-р наук з держ. упр., Національний інститут стратегічних досліджень, м. Київ, Україна

$\Phi$. Месле, д-р, науковий директор Національного інституту демографічних досліджень, м. Париж, Франція

B.M. Новіков, Д-р екон. наук, проф., ІДСД ім. М.В. Птухи НАН України

О.Ф. Новікова, д-р екон. наук, проф., Інститут економіки промисловості НАН

України, м. Київ, Україна

Б. Переллі-Харріс, д-р, проф., Саутгемптонський Університет, м. Саутгемптон, Велика Британія

I.Л. Петрова, д-р екон. наук, проф., Університет економіки і права «КРОК», м. Київ, Україна

O.B. Позняк, канд. екон. наук, ІДСД ім. М.В. Птухи НАН України

H.O. Рингач, д-р наук з держ. упр., ІДСД ім. М.В. Птухи НАН України

М.Д. Романюк, Д-р екон. наук, проф., Прикарпатський університет ім. В. Стефаника, м. Івано-Франківськ, Україна

B.Г. Саріогло, Д-р екон. наук, ІДСД ім. М.В. Птухи НАН України

M. Тольи, д-р, Інститут сучасного єврейства ім. А. Хармана, Сврейський університет у Єрусалимі, м. Єрусалим, Ізраїль

O.I. Цимбал, д-р екон. наук, Національний інститут стратегічних досліджень, м. Київ, Україна

Л.М. Черенько, канд. екон. наук, ІДСД ім. М.В. Птухи НАН України

С. Щербов, д-р, проф., Віденський інститут демографії Австрійської академії наук, м. Відень, Австрія

Д. Ясіліоніс, д-р, Інститут демографічних досліджень ім. Макса Планка,

м. Росток, Німеччина

Редакційна підготовка до друку А.І. Радиенко

Технічний секретар редакційної колегії Г.О. Москаленко

Редактор-перекладач англ. тексту T.О. Охмакевич

Комп'ютерна верстка Н.В. Тілікіної

Питання, які виникають до членів редакційної колегії журналу, направляти за E-mail:j_dse@ukr.net 
УДК 314 (051)

https://doi.org/10.15407/dse2019.02

\section{Издатели и основатели:}

Национальная академия наук

Украины

Институт демографии и

социальных исследований имени

М.В. Птухи НАН Украины

\section{Свидетельство}

о государственной

регистрации печатного

средства массовой информации

12.01.2004 г. серия КВ №8304

Перерегистрировано 22.06.2012 г. серия КВ №19037-7827 ПР

Государственной регистрационной службой Украины.

С 2015 года журнал выходит трижды в год (письмо Министерства юстиции Украины № 20679-0-33-151194 от 12.08.2015 г. о внесении разрешения в Государственный реестр печатных средств массовой информации и информационных агентств как субъектов информационной деятельности)

В соответствии с приказом МОН Украины № 32 от 15.01.2018 г. журнал «Демография и социальная экономика» входит в категорию В Перечня научных профессиональных изданий, в которых могут публиковаться результаты диссертационных работ на соискание ученых степеней доктора и кандидата наук

Утверждено к печати и публикации в сети Интернет Ученым советом Института демографии и социальных исследований им. М.В. Птухи НАН Украины 14.06.2019 г. протокол № 9

Подписано к печати 01.07.2019 г.

\section{Адрес редакции:}

Украина, 01032, г. Киев

б-р Тараса Шевченко, 60.

Тел. (044) 486-62-37

482-17-45, 486-04-97

E- mail:j_dse@ukr.net

http://www.dse.org.ua

Редакционная подготовка к печати А.И. Радиенко

Технический секретарь редакционной коллегии А.А. Москаленко Редактор-переводчик англ. текста T.О. Охмакевич Компьютерная верстка Н.В. Тиликиной

\section{РЕДАКЦИОННАЯ КОЛЛЕГИЯ}

Председатель редакционной коллегии: Э.М. ЛИБАНОВА -

директор Института демографии и социальных исследований (ИДСИ) им. М.В. Птухи НАН Украины, акад. НАН Украины, д-р экон. наук, проф. Заместитель председателя редакционной коллегии: С.И. ПИРОЖКОВ - акад. НАН Украины, д-р экон. наук, проф., вице-президент НАН Украин Заместитель председателя редакционной коллегии: Е.В. МАКАРОВА чл.-кор. НАН Украины, д-р экон. наук, зам. директора ИДСИ им. М.В. Птухи НАН Украины

Ответственный секретарь: А.Н. ГЛАДУН - чЛ.-кор. НАН Украины, д-р экон. наук, зам. директора ИДСИ им. М.В. Птухи НАН Украины

Члены редколлегии: А.Л. Баланда, д-р экон. наук, проф. Бердянский университет менеджмента и бизнеса

А.Г. Вишневский, д-р экон. наук, проф., акад. РАЭН, Государственный университет «Высшая школа экономики», г. Москва, РФ

E.A. Гришнова, д-р экон. наук, проф., КНУ им. Тараса Шевченка, г. Киев, Украина

Н.Н. Дєєва, д-р экон. наук, проф., ИДСИ им. М.В. Птухи НАН Украины Г.А. Дмитренко, д-р экон. наук, проф., Университет менеджмента образования АПН Украины, г. Киев, Украина

А.М. Ерина, д-р экон. наук, проф., ГВУЗ «КНЭУ им. В. Гетмана», г. Киев, Украина

T.A. Заяц, д-р экон. наук, проф., ИДСИ им. М.В. Птухи НАН Украины

И.С. Каленюк, д-р экон. наук, проф., Научно-исследовательский институт экономического развития ГВНЗ «Киевский национальный экономический университет им. Вадима Гетьмана»

Н.И. Карлин, д-р экон. наук, проф., Восточноевропейский национальный университет им. Леси Украинки, г. Луцк, Украина

A.M. Колот, д-р экон. наук, проф., ГВУЗ «КНЭУ им. В. Гетмана», г. Киев, Украина

И.С. Кравченко, д-р экон. наук, проф., Университет банковского дела НБУ, г. Киев, Украина

И.А. Курило, д-р экон. наук, проф. ИДСИ им. М.В. Птухи НАН Украины

H.М. Левчук, д-р экон. наук, ИДСИ им. М.В. Птухи НАН Украины

Л.С. Лісогор, д-р экон. наук, проф., ИДСИ им. М.В. Птухи НАН Украины

E.A. Малиновская, д-р наук по гос. упр., Национальный институт стратегических исследований, г. Киев, Украина

$Ф$. Месле, д-р, научный директор Национального института демографических исследований, г. Париж, Франция

B.Н. Новиков, д-р экон. наук, проф., ИДСИ им. М.В. Птухи НАН Украины O.Ф. Новикова, д-р экон. наук, проф., Институт экономики промышленности НАН Украины, г. Киев, Украина

Б. Перелли-Харрис, д-р, проф., Саутгемптонський Университет, г. Саутгемптон, Великобритания

И.Л. Петрова, д-р экон. наук, проф., Университет экономики и права «КРОК», г. Киев, Украина

A.B. Позняк, канд. экон. наук, ИДСИ им. М.В. Птухи НАН Украины

H.A. Рынгач, д-р наук по гос. упр., ИДСИ им. М.В. Птухи НАН Украины

М.Д. Романюк, д-р экон. наук, проф., Прикарпатский университет

им. В. Стефаника, г. Ивано-Франковск, Украина

В.Г. Сариогло, д-р экон. наук, ИДСИ им. М.В. Птухи НАН Украины

M. Тольи, Д-р, Институт современного еврейства им. А. Хармана, Еврейский университет в Иерусалиме, г. Иерусалим, Израиль

А.И. Цимбал, д-р экон. наук, Национальный институт стратегических исследований, г. Киев, Украина

Л.Н. Черенько, канд. экон. наук, ИДСИ им. М.В. Птухи НАН Украины

C. Щербов, д-р, Венский институт демографии Австрийской академии наук, г. Вена, Австрия

Д. Ясилионис, д-р, Институт демографических исследований им. Макса Планка, г. Росток, Германия

Вопросы к членам редакционной коллегии журнала следует направлять no E-mail:j_dse@ukr.net 
UDC 314 (051)

https://doi.org/10.15407/dse2019.02

Publishers and founders:

the National Academy

of Sciences of Ukraine,

the Ptoukha Institute for

Demography and Social Studies

of NAS of Ukraine

The Certificate of State

Registration as of 12.01.2004

Series KB № 83047. Registered as of

22.06.2012 (Series KB

№19037-7827 ПР) by Government

registration service of Ukraine.

The journal is published three times annually according to Justice of Ukraine № 20679-0-33-151194

as of August 12, 2015 about the registration of the permit in the State Register of print media and news agencies as subjects of information activity.

Ministry of Education and Science of Ukraine By Order № 32 of Janyary 15, 2018 Journal «Demography and Social Economy» is updated in the new list of scientific professional editions, which can publish the results of PhD theses in Economics

Approved for publishing and Internet publications by the Academic Senate the Ptoukha Institute for Demography and Social Studies National Academy of Sciences of Ukraine as of June, 14, 2019

\section{Editorial address:}

Ukraine, 01032, Kyiv,

blvd. Taras Shevchenko, 60.

Tel. (044) 486-62-37,

482-17-45, 486-04-97

E-mail: j_dse@ukr.net,

http // www.dse.org.ua

\section{Editorial prepress}

\section{A.I. Radchenko}

Technical Secretary of the Editorial Board A.A. Moskalenko

Editor-translator in English

T.O. Ohmakevych

Artwork

N.V. Tilikina

\section{EDITORIAL BOARD}

Editor in Chief: E.M. LIBANOVA -

Director of the Ptoukha Institute for Demography and Social Studies of the National Academy of Sciences of Ukraine, Academician of National Academy of Sciences of Ukraine, D.Sc., Prof.

Deputy Editor: S.I. PYROZHKOV - Academician of National Academy of Sciences of Ukraine, D.Sc., Prof., Vice President of NAS of Ukraine

Deputy Editor: O.V. MAKAROVA -

Corresponding Member of the NAS of Ukraine, D.Sc., Deputy Director of the Ptoukha

Institute for Demography and Social Studies of the National Academy of Sciences of Ukraine Executive Secretary: O.M. GLADUN -

Corresponding Member of the NAS of Ukraine, D.Sc., Deputy director the Ptoukha Institute for Demography and Social Studies of the National Academy of Sciences of Ukraine

\section{Editorial Board:}

A.L. Balanda, D.Sc., Prof., Berdyansk University of Management and Business

A.G. Vishnevsky, D.Sc., Prof., Academician of RAEN, National Research University Higher School of Economics, Moscow, Russia

O.A. Grishnova, D.Sc., Prof., Taras Shevchenko National University of Kyiv, Kyiv, Ukraine N.M. Deeva, D.Sc., Prof., the Ptoukha Institute for Demography and Social Studies of the National Academy of Sciences of Ukraine, Kyiv, Ukraine

G.A. Dmitrenko, D.Sc., Prof., Education Management University of the National Academy of Pedagogical Sciences of Ukraine, Kyiv, Ukraine

A.M. Yerina, D.Sc., Prof., Kyiv National Economic University named after Vadym Hetman, Kyiv, Ukraine

T.A. Zaiats, D.Sc., Prof., the Ptoukha Institute for Demography and Social Studies of the National Academy of Sciences of Ukraine, Kyiv, Ukraine

I.S. Kalenyuk, D.Sc., Prof., Research Institute for Economic Development

«Kyiv National Economic University named after Vadym Hetman», Kyiv, Ukraine

M.I.Karlin, D.Sc., Prof., Lesya Ukrainka Eastern European National University, Lutsk, Ukraine

A.M. Kolot, D.Sc., Prof., Kyiv National Economic University named after Vadym Hetman, Kyiv, Ukraine

I.S. Kravchenko, D.Sc., Prof., the University of banking of the National Bank of Ukraine, Kyiv, Ukraine

I.A. Kurylo, D.Sc., Prof., the Ptoukha Institute for Demography and Social Studies of the National Academy of Sciences of Ukraine, Kyiv, Ukraine

N.M. Levchuk, D.Sc., the Ptoukha Institute for Demography and Social Studies of the National Academy of Sciences of Ukraine, Kyiv, Ukraine

L.S. Lisogor, D.Sc., Prof., the Ptoukha Institute for Demography and Social Studies of the National Academy of Sciences of Ukraine, Kyiv, Ukraine

O.A. Malinovska, D.Sc., National Institute of Strategic Studies, Kyiv, Ukraine

F. Mesle, D.Sc., Research director, the Institut National d'Etudes Demographiques (INED), Paris, France

V.M. Novikov, D.Sc., Prof., the Ptoukha Institute for Demography and Social Studies of the National Academy of Sciences of Ukraine, Kyiv, Ukraine

O.F. Novikova, D.Sc., Prof., Institute of Industrial Economics of the National Academy of Sciences of Ukraine, Kyiv, Ukraine

B. Perelli-Harris, PhD, Associate Prof., University of Southampton, Southampton, United Kingdom

I.L. Petrova, D.Sc., Prof., University of Economics and Law «KROK», Kyiv, Ukraine D. Jasilionis, PhD, Max Planck Institute for Demographic Research, Rostock, Germany

O.V. Pozniak, PhD, the Ptoukha Institute for Demography and Social Studies of the National Academy of Sciences of Ukraine, Kyiv, Ukraine

N.O. Rynhach, D.Sc., the Ptoukha Institute for Demography and Social Studies of the National Academy of Sciences of Ukraine, Kyiv, Ukraine

M.D. Romanyuk, D.Sc., Prof., Vasyl Stefanyk Precarpathian National University, IvanoFrankivsk, Ukraine

V.G. Sarioglo, D.Sc., the Ptoukha Institute for Demography and Social Studies of the National Academy of Sciences of Ukraine, Kyiv, Ukraine

M. Tolts, PhD, Harman Institute of Contemporary Jewry, Hebrew University of Jerusalem, Jerusalem, Israel

O.I. Tsymbal, D.Sc., National Institute for Strategic Studies (NISS), Kyiv, Ukraine

L.M. Cherenko, PhD, the Ptoukha Institute for Demography and Social Studies of the

National Academy of Sciences of Ukraine, Kyiv, Ukraine

S. Scherbov, PhD, the Vienna Institute of Demography, Austrian Academy of Sciences, Vienna, Austria

D. Jasilionis, Dr., Research Scientist, Max Planck Institute for Demographic Research, Rostock, Germany

Questions to the members of the editorial Board of the journal by E-mail: $j \_d s e @ u k r . n e t$ 


\section{(2000) $)$ зм1ст}

\section{ДЕМОГРАФІЧНІ ПРОЦЕСИ}

GERASYMENKO G.V. Institutional Response to Domestic Violence in Ukraine:

Novelties in the Legislation and Access to Services

АКСЬОНОВА С.Ю. Взаємозв'язки середнього віку матері при народженні дитини

і рівня народжуваності

КРІМЕР Б.О. Політика сприяння одиноким батькам:

сучасний стан та перспективи розвитку......

ЛЕВЧУК Н.М., ЛУЩИК Л.В. Нерівність у порядку вимирання й дожиття умовних поколінь в Україні

ГРІШНОВА О.А., ХАРАЗІШВІЛІ Ю.М. Демографічна безпека України:

індифікатори, рівень, загрози

МАЙДАНІК І.П. Контекстуальні параметри зворотної трудової міграції в Україну .81

\section{СОЦІАЛЬНО-ЕКОНОМІЧНІ ПРОБЛЕМИ}

MANTSUROV I.G., KHRAPUNOVA Y.V. Statistical Measurement of the Inclusive Growth Characteristics in Ukraine .96

НОВІКОВА О.Ф., ШАМІЛЕВА Л.Л. Соціальна справедливість у процесах вимушеного переселення: оцінка та пріоритети досягнення

ЗВОНАР В.П. Фінансування соціального розвитку села за участю інститутів громадянського суспільства

ЗАЯЦЬ В.С. Розвиток житлового будівництва як фактор формування житлових умов населення.....

\section{ПРОФЕСІЙНА ОСВІТА, ПРАЦЯ ТА ЗАЙНЯТІСТЬ}

НОВІКОВ В.М. Практико-орієнтована модель професійної освіти 152

(C) Інститут демографії та соціальних досліджень імені М.В. Птухи НАН України, 2019

ISSN 2072-9480. Демографія та соціальна економіка, 2019, № 2 (36) 
ІЛЬЇЧ Л.М., КРИМОВА М.О. Методика оцінювання

конкурентоспроможності робочої сили

ТАТОМИР І.Л. Зайнятість та освітня політика в епоху штучного інтелекту

й робототехніки

\section{книжковиЙ огляд}

Соціальна безпека як інтегральний напрям державного регулювання підвищення народного добробуту. Рецензія на видання: СИДОРЧУК О.Г. Соціальна безпека: державне регулювання та організаційно-економічне забезпечення. Задорожний Г.В. 194

\section{НАУКОВЕ ЖИТТЯ}

СЛОВО ПРОЩАННЯ. Пам’яті Л.В. Чуйко 197

Правила для авторів (укр.) 199

Правила для авторов (рус.) 201

Guidelines for Authors (англ.) 203

Розміщення журналу «Демографія та соціальна економіка» в міжнародних і вітчизняних наукометричних базах, репозитариях і пошукових системах:

- $\quad$ ERIH PLUS - European Reference Index for the Humanities and the Social Sciences, Norwegian Centre for Research Data, https://dbh.nsd.uib.no/publiseringskanaler/erihplus/periodical/info?id=488830 (липень, 2016).

- Index Copernicus (Польща) http://journals.indexcopernicus.com/+++,p5172,3.html (грудень, 2013).

- Polish Scholarly Bibliography (PBN) (Польща) - наукова база даних польского Міністерства науки и Вищої Ради. PBN є частиною POL-on-The System of Information on Higher Education, https://pbn.nauka.gov. $\mathrm{pl} /$ sedno-webapp/journals/56713 (квітень, 2018).

- Ulrich's Periodicals Directory (США) www.ulrichweb.serialssolutions.com (липень, 2013).

- WorldCat, https://www.worldcat.org/title/demohrafija-ta-socialna-ekonomika-demography-and-social-economy-demografija-i-socialnaja-ekonomika/oclc/907381882\&referer=brief_results (листопад, 2013).

- РИНЦ (RISC, РФ), http://elibrary.ru/title_about.asp?id=38295 (серпень, 2015).

- EZB - Elektronische Zeitschriftenbibliothek, (Universitätsbibliothek Regensburg, (Німеччина)), http://ezb. uni-regensburg.de/?2815935 (серпень, 2016).

- Google Scholar, https://scholar.google.com.ua/citations?hl=ru\&user=BuMC3voAAAAJ\&view_op=list_works\&sortby=pubdate (грудень, 2015).

- IBSS: International Bibliography of the Social Sciences, (United Kingdom), http://www.proquest.com/ documents/Title_List__International_Bibliography_of_the_Social_Sciences.html (липень, 2016).

- Cosmos Impact Factor, http://www.cosmosimpactfactor.com/page/journals_details/4229.html (квітень, 2018)

- CrossRef, https://doi.org/10.15407/dse (грудень, 2015).

- Наукова періодика України (Uran Publish Servis, OJS), http://journals.uran.ua/index.php/2309-2351 (червень, 2016).

- Українські наукові журнали (березень, 2016).

- Інформаційно-аналітична система «Бібліометрика української науки», Ranking of Scientists (Cybermetrics Lab) Національної бібліотеки України імені B.I. Вернадського (лютий, 2013). 


\section{СОДЕРЖАНИЕ}

\section{ДЕМОГРАФИЧЕСКИЕ ПРОЦЕССЫ}

ГЕРАСИМЕНКО А.В. Институциональное регулирование проблемы домашнего насилия

в Украине: новеллы законодательства и доступ к услугам

АКСЁНОВА С.Ю. Взаимосвязи среднего возраста матери при рождении ребенка

и уровня рождаемости

КРИМЕР Б.А. Политика содействия одиноким родителям:

современное состояние и перспективы развития.

ЛЕВЧУК Н.М., ЛУЩИК Л.В. Неравенство в порядке вымирания и дожития условных поколений в Украине

ГРИШНОВА Е.А., ХАРАЗИШВИЛИ Ю.М. Демографическая безопасность Украины: индикаторы, уровень, угрозы

МАЙДАНИК И.П. Контекстуальные параметры возвратной трудовой миграции

в Украину .81

\section{СОЦИАЛЬНО-ЭКОНОМИЧЕСКИЕ ПРОБЛЕМЫ}

МАНЦУРОВ И.Г., ХРАПУНОВА Я.В. Статистическое измерение характеристик инклюзивного роста в Украине .96

НОВИКОВА О.Ф., ШАМИЛЕВА Л.Л. Социальная справедливость в процессах вынужденного переселения: оценка и приоритеты достижения .....

ЗВОНАРЬ В.П. Финансирование социального развития села

с участием институтов гражданского общества. 121

ЗАЯЦ В.С. Развитие жилищного строительства как фактор формирования жилищных условий населения

\section{ПРОФЕСИОНАЛЬНОЕ ОБРАЗОВАНИЕ, РАБОТА И ЗАНЯТОСТЬ}

НОВИКОВ В.Н. Практико-ориентированная модель профессионального образования 152

(С) Институт демографии и социальных исследований имени М.В. Птухи НАН Украины, 2019 
ИЛЬИЧ Л.Н., КРЫМОВА М.О. Методика оценивания конкурентоспособности рабочей силы

ТАТОМИР И.Л. Занятость и образовательная политика в эпоху искусственного интеллекта и робототехники

\section{КНИЖНЫЙ ОБЗОР}

Социальная безопасность как интегральное направление государственного регулирования повышения народного состояния. Рецензия на издание: СИДОРЧУК О.Г. Социальная безопасность: государственное регулирование и организационно-экономическое обеспечение. Задорожный В.Г.

\section{НАУЧНАЯ ЖИЗНЬ}

СЛОВО ПРОЩАНИЯ. Памяти Л.В. Чуйко 197

Правила для авторов (укр.) 199

Правила для авторов (рус.) 201

Правила для авторов (англ.) 203

Размещение журнала «Демография и социальная экономика» в международных и отечественных наукометрических базах, репозитариях и поисковых системах:

- $\quad$ ERIH PLUS - European Reference Index for the Humanities and the Social Sciences, Norwegian Centre for Research Data, https://dbh.nsd.uib.no/publiseringskanaler/erihplus/periodical/info?id=488830 (июль, 2016).

- Index Copernicus (Польша) http://journals.indexcopernicus.com/+++,p5172,3.html (декабрь, 2013).

- Polish Scholarly Bibliography (PBN) (Польша) - научная база данных польского Министерства науки и Высшего Совета. PBN является частью POL-on-The System of Information on Higher Education, https:// pbn.nauka.gov.pl/sedno-webapp/journals/56713 (апрель, 2018).

- Ulrich's Periodicals Directory (США) www.ulrichweb.serialssolutions.com (июль, 2013).

- WorldCat, https://www.worldcat.org/title/demohrafija-ta-socialna-ekonomika-demography-and-social-economy-demografija-i-socialnaja-ekonomika/oclc/907381882\&referer=brief_results (ноябрь, 2013).

- РИНЦ (RISC, РФ), http://elibrary.ru/title_about.asp?id=38295 (август, 2015).

- EZB - Elektronische Zeitschriftenbibliothek, (Universitätsbibliothek Regensburg, (Германия)), http://ezb.uniregensburg.de/?2815935 (август, 2016).

- Google Scholar, https://scholar.google.com.ua/citations?hl=ru\&user=BuMC3voAAAAJ\&view_op=list_works\&sortby=pubdate (декабрь, 2015).

- IBSS: International Bibliography of the Social Sciences, (United Kingdom), http://www.proquest.com/documents/Title_List___International_Bibliography_of_the_Social_Sciences.html (июль, 2016).

- Cosmos Impact Factor, http://www.cosmosimpactfactor.com/page/journals_details/4229.html (апрель, 2018)

- CrossRef, https://doi.org/10.15407/dse (декабрь, 2015).

- Научная периодика Украины (Uran Publish Servis, OJS), http://journals.uran.ua/index.php/2309-2351 (февраль, 2016).

- Украинские научные журналы (март, 2016).

- Информационно-аналитическая система «Библиометрика украинской науки», Ranking of Scientists (Cybermetrics Lab) Национальной библиотеки Украины имени В. Вернадского (февраль, 2013). 


\section{DEMOGRAPHIC PROCESSES}

GERASYMENKO G.V. Institutional Response to Domestic Violence in Ukraine:

Novelties in the Legislation and Access to Services

AKSYONOVA S.Yu. The Relation of the Mean Age of Women at Childbearing and Fertility Rate.

KRIMER B.O. Lone Parents Policy: Modern Development

LEVCHUK N.M., LUSCHIK L.V. Inter-Individual Inequality in Length of Life

in Ukraine

GRISHNOVA O.A., KHARAZISHVILI Yu.M. Demographic Security of Ukraine:

Indicators, Level, Threats .65

MAIDANIK I.P. Contextual Parameters of Return Labor Migration to Ukraine. .81

\section{SOCIO-ECONOMIC PROBLEMS}

MANTSUROV I.G., KHRAPUNOVA Y.V. Statistical Measurement of the Inclusive Growth Characteristics in Ukraine .96

NOVIKOVA O.F., SHAMILEVA L.L. Social Justice in the Processes of Forced Resettlement:

Evaluation and Priorities of Achievement

ZVONAR V.P. Financing of Rural Communities Social Development:

the Stake of Civil Society Institutions

ZAIATS V.S. Housing Construction Development as a Factor of Formation of Housing Conditions of Population .....

\section{PROFESSIONAL EDUCATION, WORK AND EMPLOYMENT}

NOVIKOV V.M. Practice-Oriented Model of Professional Education 
TATOMUR I.L. Employment and Education Policies in the Era of Artificial

Intelligence and Robotics

\section{BOOK REVIEW}

Social security as an integral direction of state regulation of raising public welfare. Review of the publication: SIDORCHUK O.G. Social security: state regulation and organizational and economic support. Zadorozhny G.V.

\section{SCIENTIFIC LIFE}

THE WORD OF FOREVER. The memory of L.V. Chuyko 197

Guidelines for Authors (ukr.)

Guidelines for Authors (rus.)

Guidelines for Authors (eng.)

«Demography and social economy» in international and domestic scientometric databases, repositories and search engines

- ERIH PLUS - European Reference Index for the Humanities and the Social Sciences, Norwegian Centre for Research Data, https://dbh.nsd.uib.no/publiseringskanaler/erihplus/periodical/info?id=488830 (2016).

- Index Copernicus (Польща) http://journals.indexcopernicus.com/+++,p5172,3.html (2013).

- Polish Scholarly Bibliography (PBN) (Poland) - a scientific database of the Polish Ministry of Science and the Supreme Council. The PBN is part of POL-on-The System of Information on Higher Education, https://pbn. nauka.gov.pl/sedno-webapp/journals/56713 (April, 2018).

- Ulrich's Periodicals Directory (США) www.ulrichweb.serialssolutions.com (2013).

- WorldCat, https://www.worldcat.org/title/demohrafija-ta-socialna-ekonomika-demography-and-social-economy-demografija-i-socialnaja-ekonomika/oclc/907381882\&referer=brief_results (2015).

- $\quad$ RISC (РИНЦ, RF), http://elibrary.ru/title_about.asp?id=38295 (2015).

- $\quad$ EZB - Elektronische Zeitschriftenbibliothek, (Universitätsbibliothek Regensburg, (Germany)), http://ezb.uniregensburg.de/?2815935 (2016).

- Google Scholar, https://scholar.google.com.ua/citations?hl=ru\&user=BuMC3voAAAAJ\&view_op=list_works\&sortby=pubdate (2015).

- IBSS: International Bibliography of the Social Sciences, (United Kingdom), http://www.proquest.com/documents/Title_List_-_International_Bibliography_of_the_Social_Sciences.html (2016).

- Cosmos Impact Factor, http://www.cosmosimpactfactor.com/page/journals_details/4229.html (2018)

- CrossRef, https://doi.org/10.15407/dse (2015).

- Academic Periodicals of Ukraine (Uran Publish Servis, OJS), http://journals.uran.ua/index.php/2309-2351 (2016).

- «Ukrainian Academic Journals» (2016).

- Information and analytical system «Bibliometrics of the Ukrainian Science», Ranking of Scientists (Cybermetrics Lab) Vernadskyi National Library of Ukraine (2016). 


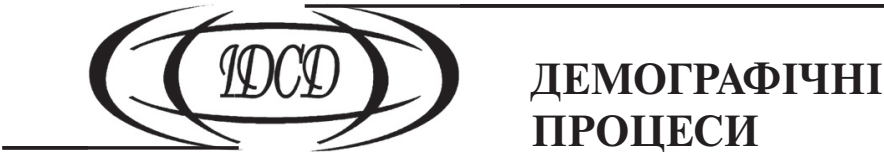

https://doi.org/10.15407/dse2019.02.011

UDC $314.18: 316.42(477)$

JEL CLASSIFICATION: I31

\section{G.V. GERASYMENKO}

$\mathrm{PhD}$ (Economics), Leading Researcher,

Ptoukha's Institute for Demography and Social Studies

of the National Academy of Sciences of Ukraine

01032, Ukraine, Kyiv, Taras Shevchenko Blvd., 60

E-mail: geranna@ukr.net

ORCID 0000-0002-2854-7257

\section{INSTITUTIONAL RESPONSE TO DOMESTIC VIOLENCE IN UKRAINE: NOVELTIES IN THE LEGISLATION AND ACCESS TO SERVICES}

\begin{abstract}
The article addresses the issues related to the development of a proper institutional environment in order to prevent and combat domestic violence in Ukraine. The study objectives are targeted at examination of the gaps that restrain the efficiency of the present system of response to the incidents of domestic violence and development of the recommendations on potential ways to solve these problems. A review of the recent studies on gender-based and domestic violence is provided by the author. The novelties of the national legislation are examined in detail, in particular those that provide new tools and mechanisms to strengthen the protection of the victims of violence and to prosecute the offenders effectively. In particular, the new Law of Ukraine 'On Preventing and Combating Domestic Violence' institutionalizes the concepts of psychological and economic violence, introduces a system of special measures against the perpetrators, including emergency protection order (EPO), and specialized services for the victims of domestic violence. It is important that the Law identifies a clear procedure for the interaction of all actors involved in prevention-and-response to domestic violence in order to provide a prompt assistance to those in need. The article also provides an overview of important by-laws passed to meet the requirements of the Law and designed to strengthen a fight against domestic violence.

The author analyzes the features of the modern system of response to domestic violence, including activities of various actors - the law enforcement agencies, centers of social services, shelters for the victims of domestic violence, the national hotline on gender-based discrimination and domestic violence, etc. The innovative projects of prevention of domestic violence have been implemented in the country, including mobile brigades of social and psychological assistance and the Polina Police Network against Domestic Violence. Based on the results of the analysis, general conclusions are drawn about the gaps that persist in the coordination processes, and recommendations are provided on improving the institutional mechanisms for combating domestic violence.

The study findings can be used to develop public policy, to implement the information campaigns and to ground advocacy efforts to improve the entire system of services provided to the victims of violence and their families.
\end{abstract}

Keywords: domestic violence, Law of Domestic Violence, police network against domestic violence, social services, mobile brigades of social and psychological help. 


\section{Г.В. Герасименко}

канд. екон. наук, пров. наук. співроб.

Інститут демографії та соціальних досліджень ім. М.В. Птухи

Національної академії наук України

01032, Україна, м. Київ, бул. Т. Шевченка, 60

E-mail: geranna@ukr.net

ORCID 0000-0002-2854-7257

\section{ІНСТИТУЦИЙНЕ РЕГУЛЮВАННЯ ПРОБЛЕМИ ДОМАШНЬОГО НАСИЛЬСТВА В УКРАЇНІ: НОВЕЛИ ЗАКОНОДАВСТВА ТА ДОСТУП ДО ПОСЛУГ}

Висвітлено питання розбудови інституційного середовища протидіїдомашньому насильству в Україні. Завдання дослідження полягають у визначенні прогалин, які обмежують ефективність сучасної системи реагування на випадки домашнього насильства, та обгрунтуванні рекомендацій щодо можливих шляхів вирішення цих проблем. 3 цією метою автором детально розглянуто останні новели вітчизняного законодавства, покликані посилити механізми захисту постраждалих від насильства та притягнення кривдників до відповідальності. Зокрема, новим Законом України «Про запобігання та протидію домашньому насильству» інституціоналізовано поняття психологічного та економічного насильства, запроваджено систему спеціальних заходів по відношенню до кривдників, у тому числі терміновий заборонний припис, передбачено надання спеціалізованих послуг особам, які постраждали від домашнього насильства. Важкливо, що законом визначено чіткий порядок взаємодії всіх суб'єктів, залучених до запобігання та протидії домашньому насильству, з метою надання оперативної допомоги тим, хто ї потребує. Представлено огляд важливих підзаконних актів, ухвалених на виконання вимог закону та покликаних сприяти ефективній боротьбі з домашнім насильством.

Розглянуто особливості сучасної системи протидії домашньому насильству, зокрема діяльність різних суб'єктів - правоохоронних органів, центрів надання соціальних послуг, притулків, національної гарячої лінії для постраждалих від насильства та ін. Представлено результати реалізації інноваційних проектів із протидії домашньому насильству, що реалізуються в країні, а саме діяльності мобільних бригад соціально-психологічної допомоги та пілотної поліцейської мережі з протидії домашньому насильству «Поліна». За підсумками аналізу сформовано загальні висновки щодо прогалин, які зберігаються в координації діяльності різних суб'єктів, та представлено рекомендації щодо вдосконалення інституційних механізмів боротьби з домашнім насильством. Результати дослідження можуть бути використані для розробки заходів державної політики, формування інформаційних кампаній та обгрунтування адвокаційних зусиль із метою вдосконалення всієї системи послуг, що надаються постраждалим від насильства та їхнім сім'ям.

Ключові слова: домашне насильство, поліцейська мережа з протидії домашньому насильству, соціальні послуги, мобільні бригади соціально-психологічної допомоги.

\section{А.В. Герасименко}

канд. экон. наук, вед. науч. сотр.

Институт демографии и социальных исследований им. М.В. Птухи

Национальной академии наук Украины

01032, Украина, г. Киев, бульв. Т. Шевченка, 60

E-mail: geranna@ukr.net

ORCID 0000-0002-2854-7257

\section{ИНСТИТУЦИОНАЛЬНОЕ РЕГУЛИРОВАНИЕ ПРОБЛЕМЫ ДОМАШНЕГО НАСИЛИЯ В УКРАИНЕ: НОВЕЛЛЫ ЗАКОНОДАТЕЛЬСТВА И ДОСТУП К УСЛУГАМ}

Освещены вопросы развития институциональной среды противодействия домашнему насилию в Украине. Детально рассмотрены последние новеллы отечественного законодательства, призванные усилить механизмы защиты пострадавщих от насилия и привлечения обидчиков к ответственности. В частности, новым Законом Украины «О предотвращении и противодействии домашнему насилию» институциализировано понятие психологического и экономического насилия, введена система специальных мер по отношению к обидчикам, в том числе срочное запретное предписание, предусмотрено предоставление специализированных услуг для лии, пострадавших от домашнего насилия. Важно, что 
законом определен четкий порядок взаимодействия всех субъектов, вовлеченных в предотвращение и противодействие домашнему насилию, с иелью оказания оперативной помощи всем, кто в ней нуждается. Представлен обзор важных подзаконных актов, принятых в связи с требованиями закона и призванных способствовать эффективной борьбе с домашним насилием. Рассмотрены особенности современной системы противодействия домашнему насилию, включая деятельность различных субъектов - правоохранительных органов, центров предоставления социальных услуг, приютов, национальной горячей линии для пострадавших от насилия и пр. Представлены результаты реализации инновационных проектов по противодействию домашнему насилию, реализуемых в стране, а именно деятельности мобильных бригад социально-психологической помощи и пилотной полицейской сети по противодействию домашнему насилию «Полина». По итогам анализа сформированы общие выводы относительно пробелов, сохраняющихся в координации деятельности различных субъектов, и представлены рекомендации по совершенствованию институциональных механизмов борьбы с домашним насилием. Результаты исследования могут быть использованы для разработки мер государственной политики, формирования информационных кампаний и обоснования адвокационных усилий с иелью совершенствования всей системы услуг пострадавшим от насилия и их семьям.

Ключевые слова: домашнее насилие, полицейская сеть по противодействию домашнему насилию, социальные услуги, мобильные бригады социально-психологической помощи.

Introduction. The problem of domestic violence is a grave phenomenon that affects women, men and children. According to the National Police of Ukraine, there were 115,473 appeals on domestic violence received in 2018, of them 89,498 appeals $(77.5 \%)$ were provided by women, 1,418 appeals $(1.2 \%)$ - by children. To respond to these challenges, the new Law of Ukraine 'On Preventing and Combating Domestic Violence' was adopted in December 2017. This law was an important departure from previous legislation as it introduces new concepts and mechanisms for protecting survivors of domestic violence. The Law institutionalizes the concepts of emotional and economic violence, introduces a system of special measures imposed on offenders, such as emergency protection orders, and foresees a number of services for domestic violence survivors. Importantly, it provides the guidelines for coordination of activities of all stakeholders in the field of prevention and counteraction to domestic violence in order to provide prompt assistance to those who need it.

Literature review. The problems of domestic violence have been studied by national experts in the field of administrative and criminal law, sociology, psychology and behavioral studies, healthcare and human rights. The most valuable academic contribution was provided by K. Levchenko and M. Legenka [1; 2], O. Kalashnyk [3,] G. Khrystova [4], O. Kochemyrovska, M. Khavronyuk and I. Demchenko [5]. A number of instrumental studies and rapid assessments were also conducted in Ukraine over the last few years to support policy-setting on domestic violence and development of the advocacy tools. In particular, the Council of Europe Project "Combating violence against women and children in Ukraine" (2016-2018) drafted the Recommendations for the Ministry of Social Policy of Ukraine on taking a strategic approach to increase the awareness of the population on violence against women and children [6], and a Feasibility Study for testing in Ukraine the Barnahus Model "Protecting Children from Sexual Exploitation and Sexual Violence" [7].

The 2012 Multiple Indicator Cluster Survey in Ukraine (MICS) examined public attitudes towards domestic violence in Ukraine [8]. In particular, the survey assessed whether women and men believe that husband/partner is justified in beating his wife. Overall, men were more likely than women to agree with one of the reasons to justify wife beating ( $9 \%$ of men compared to $3 \%$ of women), and the most prevalent justifying reasons were related to the neglect of children, disobeying and refusal to have sex.

In 2016-2017, UNFPA in Ukraine implemented the innovative study "Economic Cost of Violence against Women in Ukraine" [9] aimed at enhancing advocacy efforts on combating 
GBV. In particular, the study estimates that the total losses borne by society due to violence against women could be as much as USD 208 million ( $0.23 \%$ of the country's GDP). Based on an extrapolation of the GBV data onto the entire female population of Ukraine, the number of women aged 15-49 who were subjected to physical and/or sexual violence was estimated at 1.1 million women per year.

The 2018 UNFPA study “Masculinity Today: Men's Attitudes to Gender Stereotypes and Violence against Women" explored men's attitudes toward domestic violence and the patterns of behaviour of perpetrators of domestic violence in Ukraine [10]. More than 1,500 adult men were surveyed in the framework of this study. Close to one-third reported that they had committed emotional violence in their partnership, $14 \%$ said that they committed economic violence, and $13 \%$ said that they perpetrated physical violence against their partner.

Paper objective and novelties. With this paper, we sought to take stock of previous assessments and to further understand the current institutional approaches to domestic violence cases more specifically, as well as the availability of services for survivors. Despite of many investments being allocated to prevent GBV and provide a proper response to the victims of violence, there are no public guidelines to ask for help in case of domestic violence, while many people and unaware of the available services. With this paper, we try to identify the current gaps in the system of different service providers and develop a set of recommendations to strengthen the institutional response to domestic violence through improving the current police approaches and developing the system of support services of the survivors of violence.

Study methods. The article is generally based on the secondary data analysis, including the literature and legislation review. In addition, content-analysis techniques were implemented to collect data on the recent initiatives on the response to domestic violence in Ukraine.

The main research findings. Since 2001, the framework of the Law of Ukraine "On Forestalling Violence in a Family" has provided institutional regulation aimed at preventing and combating domestic violence. As of the date of adopting the Draft Law in question, Ukraine was the first state among the post-Soviet territories to develop its regulatory and legal pillars and arrangements as a matter of law. However, as the law enforcement bodies had gradually acquired the experience, some provisions of that Law gained recognition of being inefficient and incompatible with the contemporary European standards. After signing the Council of Europe Convention "On Preventing and Combating Violence against Women and Domestic Violence" (the Istanbul Convention) in 2011, updating Ukraine's legal base and bringing it into conformity with the provisions of international law ${ }^{1}$ is even more necessary.

The extended advocacy campaign and public discussions in December 2017 resulted in the adoption of the new Law "On Preventing and Combating Domestic Violence" that determined organizational and legal platform for preventing and combating domestic violence in the country, the key targets for official policy to be implemented in this area while being focused on protecting rights and interests of the persons that have suffered such violence.

The Law provides for a comprehensive approach to the implementation of an official policy on domestic violence, including the following clauses:

- the Law shall apply, but not be limited to, immediate family members (the perpetrators of violence), extending beyond to apply to the formerly married and the betrothed, other relatives sharing a household;

\footnotetext{
1 The Istanbul Convention requires the governments of its undersigned states to take specific actions aimed at combating any kind of violence against women as ranging from sexual harassment and violence in a family to a forced marriage and female genital mutilation.
} 
- improvements to be introduced to the system for collecting, processing and analysing the data with the establishment of a Single Public Databank to register the incidents of domestic violence and the gender-based violence which shall have its data registered subject to the consent provided by the aggrieved persons;

- extending the list of administrative and legal liability for the actions qualifying as domestic violence and the restrictive actions to be applied to the perpetrators (including the introduction of urgent prohibition and restriction orders against the perpetrator, initiating preventive police records and providing preventive treatment of the perpetrators, ordering the perpetrators for completing a programme for perpetrators);

- supplementing the list of entities taking action aimed at preventing and combating domestic violence with education and health facilities, including establishing the Official Call Centre for Preventing and Combating Domestic Violence, GenderSpecific Violence and the Violence Against Children (hereinafter the Call Centre), and putting in place the system of safe temporary hosting locations (shelters) for the persons who have suffered violence as well as proper infrastructure for the corrective programmes to be completed by the perpetrators;

- extending the powers of the NPU related to cases of domestic violence, including to receive and review the claims and notifications on domestic violence committed, as filed to the Call Centre, to allow entering premises without a court decision in urgent cases related to health and life threatening hazards due to domestic violence, to cancel the permits for purchasing, keeping, wearing arms and ammunition in the event of their owners committing domestic violence;

- enhancing attention to the conditions of children who have witnessed violence in their families, in particular granting them the special status of survivor that grants them the right to access relevant services available to survivors of domestic violence.

Novelties of the law include, but are not limited to, reinstating the penalties as a levy for committing domestic violence, gender-specific violence or failure to comply with an urgent order of prohibition ${ }^{2}$. It is to be noted that Ukraine's human rights activists are rather critical in their assessment of the fines for domestic violence committed to be reinstated as a levy, as long as the expenses to pay thereof are typically incurred by the joint family budget, thus, apart from affecting family welfare, this might enhance its internal tensions.

The adoption of the new Law "On Preventing and Combating Domestic Violence" coincided with amendments introduced into the Criminal and the Criminal Procedure Codes of Ukraine to strengthen criminal responsibility for domestic violence and violence against women. The Criminal Code of Ukraine (CCU) incorporated new Article 1261 "Domestic Violence" to be interpreted as intentional and systematic physical, psychological or economic violence committed against a current or former partner or against another person with whom the offender has been maintaining or used to maintain family or close relations resulting in physical or mental suffering, health issues, inability to work, emotional dependence or a deterioration of the quality of life of the survivor. Penalties include community service for the period of 150 to 240 hours, detention for up to six months, restriction of liberty for up to five years, or deprivation of liberty for up to two years. The new amendments also increase

\footnotetext{
${ }^{2}$ Pursuant to the Article 172-3 of the Code of Ukraine on Administrative Offences (CoUAO), committing domestic violence shall entail a fine to be imposed to the amount of ten to twenty amounts of the minimum wage that is not taxable or community service for the period of thirty to forty hours or an administrative detention for up to seven days. A domestic violence committed repeatedly provides for a fine to be imposed to the amount of twenty to forty amounts of the minimum wage that is not taxable or community service for the period of forty to sixty hours or an administrative detention for up to fifteen days.
} 
perpetrators' responsibility in cases where the violence committed is witnessed by a minor child, in which case the child will qualify as a survivor.

Despite experts generally praising the progress on this legislation, some human rights defenders remain critical. In particular, the draft laws submitted to Parliament included such terms as "gender", "gender-based violence", "gender stereotypes" and other derived terms used in the Istanbul Convention. However, these key concepts have been removed from the final edition of the law. Instead, the regulatory and legal environment has adopted the term "gender-specific violence", which does not fully comply with the concept of gender-based violence as the former downplays the core principles of comprehending the socially designed inequality and the power relationships incorporated in the latter. Some also suggest that the Ukrainian legislation cannot comply with its international obligations unless the definitions apply as derived from the term "gender". In general, the ratification of the Istanbul Convention poses a major challenge to Ukrainian society, although it is a necessary step to ensure comprehensive reforms to combating the gender-based violence take place.

On 22 August 2018, the Cabinet of Ministers of Ukraine approved three major normative acts expected to enhance intersectoral cooperation aimed at combating domestic violence:

1) Creation of Mobile Brigades for Social and Psychological Aid:

Resolution of the Cabinet of Ministers of Ukraine "On Approving a Standard Provision on Mobile Brigade for Social and Psychological Aid for the Persons Who Have Suffered Domestic Violence and Gender-Specific Violence" regulating the emergency response arrangement to events of violence. Pursuant to this Resolution, mobile brigades are dedicated teams supporting the persons who have suffered domestic violence - who shall provide survivors with physiological aid and skilled consulting services involving on-site visits to the families in need, as well as over the phone ${ }^{3}$. The mobile brigades will reinforce local communities in providing their residents with access to high-quality social and rehabilitation services and violence event emergency response by the agencies implementing measures aimed at preventing and combating domestic violence;

2) Provision of Shelters for Survivors of Domestic Violence:

Resolution of the Cabinet of Ministers of Ukraine "On Approving a Standard Provision on a Shelter for the Persons Who Have Suffered Domestic Violence and Gender-Specific Violence" determines the arrangement for setting up safe temporary hosting locations for survivors. The Resolution was drafted pursuant to the Laws of Ukraine "On Preventing and Combating Domestic Violence" and "On Ensuring Equal Rights and Opportunities for Women and Men", which provide for the introduction of an effective workflow for providing aid and protection to those who have suffered domestic violence and gender-specific violence, in particular the setting up of dedicated support services for such persons. The key objective of setting up shelters is to provide safe temporary hosting locations for survivors and a comprehensive support, including psychological support, social and domestic support, as well as information and legal services. Local executive power bodies and local governments shall establish the shelters according to the needs of a local community.

\footnotetext{
${ }^{3}$ According to the normative definition, a mobile brigade of social and psychological assistance is a specially formed association of specialists (practical psychologist, social worker) providing emergency and planned social and psychological assistance to the victims of gender-based violence, incl. persons under the age of 18, through response and referrals by means of special transport or at specialized premises of social service centers for families, children and youth or other social service providers in the settlements of regions.

The first mobile brigades were launched by UNFPA and Ukrainian Foundation for Public Health in cooperation with MoSP in 2015. As of today, a total of 46 mobile social and psychological aid brigades are functioning in different regions of the country.
} 
Implementation of the adopted Resolution is to facilitate the incorporation into national law of the international standards covering the provision of aid to survivors of domestic and gender-based violence, improvements to the social protection for the persons aggrieved by this violence, and introduction of these new services in local communities. The latter recognizes that timely delivery of high-quality social and rehabilitation services for domestic violence survivors is critical for the recovery of survivors socially, mentally, psychologically and physically.

3) Creation of a Coordination Mechanism:

The Resolution of the Cabinet of Ministers of Ukraine "On Approving the Arrangement for Interaction of the Agencies Taking Measures aimed at Preventing and Combating Domestic Violence and Gender-Specific Violence": determining the specific procedures for revealing the cases of violence committed and relevant response by local public administrations, local governments, the NPU bodies, education and public health facilities, agencies supporting the aggrieved. Introduction of the arrangement for interaction aims at coordinating the response measures applicable to the cases of violence and effective aid to be made available to the aggrieved persons as implemented by a variety of entities, development and implementation of the programs for the perpetrators and the aggrieved. The Instrument, once implemented, will establish the procedures for the exchange of information among the entities that take measures aimed at preventing and combating the violence, as well as for monitoring those measures. Timely delivery in the shelters of high-quality social and advocacy services for domestic violence and gender-specific violence survivors is to contribute best to their social, mental, psychological and physical recovery.

In order to implement p.11 of Article 25 of the Law of Ukraine "On Preventing and Combating Domestic Violence", the MoI issued the Order dated August 1, 2018 \#654 "On Approval of the Procedure for Issuing the Emergency Protection Order Applicable to Perpetrators of Domestic Violence by the Authorities Sub-Units of the National Police". It was registered in the MoJU on the 28 $8^{\text {th }}$ of October 2018 (№ 965/32417).

The Order defines the procedure for the following restricting measures against the perpetrators of domestic violence: the obligation to leave a place of residence (stay) of the survivor, the prohibition on entering and staying at the place of residence (stay) of the survivor, the prohibition to contact the survivor in any way. Despite the urgency of these measures, the possibility of their application in practice has been limited by the lack of the normative procedure for making assessment of the further risks of domestic violence that should be used for argumentation of the relevant decisions.

Other important steps in drafting the normative acts relate to the following:

- Procedure for developing, maintaining and accessing the unified state databank to register the incidents of domestic violence and the gender-based violence;

- Regulation on the Call centre for preventing and combating domestic violence and gender-based violence and the violence against children;

- Procedure for addressing the claims and notifications on domestic violence committed against children;

- Technical guidance for the experts working with children and youth regarding the innovative measures to be taken in order to convey to the children and youth a zero-tolerance towards violent behaviour patterns, empathic approach towards the survivors of violence, the idea of domestic violence as a human rights violation;

- Model regulations for centers for medical and social rehabilitations for survivors of domestic violence; 
- Standard for providing medical care for the persons who have suffered domestic violence and gender-based violence or for the persons who have been likely to suffer such a violence;

- Procedure for conducting and recording the medical check-ups of survivors of domestic violence or gender-based violence;

- State standard for providing social services to the persons who have suffered domestic violence;

- Techniques applicable to identifying the need of local communities for establishing the specialized support services for survivors of domestic violence;

- Learning and mentoring programs for preventing and combating domestic violence, and the mentoring and information and outreach events to be held on the issues in question with parents and children in the education facilities.

Finally, the Concept of the State Social Program on Preventing and Combating Domestic Violence and Gender-based Violence for the Period till 2023 has been adopted by the Cabinet of Ministers of Ukraine on October 10, $2018(\# 728-\mathrm{p})^{4}$. The Concept addresses the main causes of domestic violence and gender-based violence, including:

- the prevalence of stereotypes on the social role of women and men, the subordinary position of one gender over another in terms of intensity of physical strength;

- the widespread impunity of perpetrators of domestic violence and gender-based violence and the prevalence of such a phenomenon;

- he stereotyped public perceptions of the private character of domestic violence;

- the use of violent patterns of behaviour by children who have been subjected to domestic violence in any form or who have witnessed such violence (;

- the low public trust in authorities, public bodies and institutions, which are entrusted with functions to prevent and combat domestic violence and gender-based violence;

- the low availability of comprehensive services for survivors of violence due to imperfect mechanisms of interaction between the actors involved to prevent-and-respond to domestic violence and gender-based violence, the lack of skills and training among these specialists, psychological burnout among the professionals, and limited human resources, in particular, in terms of social workers, psychologists, specialized institutions for survivors;

- the imperfect mechanism of bringing the perpetrators of domestic and gender-based violence to justice;

- the lack of systematic research and analysis on the prevalence of domestic violence, violence against children, and gender-based violence, and the gaps in the system of data collection.

The national system for responding to cases of domestic violence consists of a wide range of institutions. In general, the set of relevant measures may involve over 15 different arms, including:

- a dedicated and authorized central body of executive power providing the development of public policy aimed at preventing domestic violence (the Ministry of Social Policy of Ukraine);

- local executive power bodies, local governments and their incorporated units (departments (directorates) for residential welfare, departments (sectors) for family and youth) that coordinate activities on preventing domestic violence at the regional and local level;

\footnotetext{
${ }^{4}$ https://zakon.rada.gov.ua/laws/show/728-2018-\%D1\%80
} 
- the authorized units of the National Police bodies (5 units and more can be involved, subject to severity of the offence);

- custody and guardianship authorities, childcare services that protect the rights and interests of children in the circumstances related to the domestic violence;

- public health institutions, establishments and institutions;

- education management systems, education facilities and institutions of educational system;

- centers providing free secondary legal aid that provide legal support to the victims of violence;

- general and dedicated support services for the victims of violence (shelters, crisis centres, social and psychological aid centres, etc.);

- other parties concerned (enterprises, institutions, organizations regardless of their form of ownership) providing social, information and outreach services aimed at preventing and combating domestic violence.

At the beginning of 2018, there were 692 centers of social services for the family, children and youth (464 district centers, 138 city centers, 31 district centers in cities, 34 town and village centers) providing their services to people in difficult straits. Comprehensive support for survivors of domestic violence was provided by 20 social and psychological support centers. Female minors who had suffered violence were provided with access to the aid they need in the 83 centers for social and psychological rehabilitation and the shelters for children. In addition, 21 centers for female minors with kids were in operation.

The International Charity Fund "The Ukrainian Foundation for Public Health" and the "Health Right" jointly with the Kyiv City Centre of Social Services for Family, Children and Youth provided the activity of social apartment for pregnant girls and mothers taking care of infant age kids when in difficult straits. The NGO "Convictus-Ukraine" launched the Center of Psychological and Social Support for Women Subjected to Violence, which facilities implement dedicated rehabilitation programmes and provide the option of safe temporary hosting for 15 women (including women with kids).

During the period of 2016 to 2018, the UNFPA contributed to opening five shelters for the survivors of gender-based violence, which operate 24/7 in Kharkiv, Berdyansk, Kryvy Rih, Mariupol and Vinnytsia. Apart from safe hosting (up to 6 months), those facilities provide social and psychological, legal and medical care for the women who have suffered violence. The day crisis center for women who were subjected to gender-based and domestic violence is also being created in Kharkiv presently. As of the end of 2017, the facilities provided services to 148 persons aggrieved by the gender-based violence which found the shelters by referencing from the family, children and youth centers or mobile social and psychological aid brigades.

At the end of 2018, there were 50 mobile brigades operating in Ukraine, which provided psychological and social assistance in cases of violence, including in the most remote settlements. This project has been implemented by the UNFPA in 10 regions of Ukraine, including Vinnytsia, Dnipropetrovsk, Zaporizhia, Kyiv, Lviv, Odessa, Kharkiv, Kherson, Mykolaiv, Rivne oblasts, and the government-controlled territories of Donetsk and Luhansk regions. Only in 2017, the mobile brigades provided assistance to more than 13,000 survivors of gender-based and domestic violence.

Positively, local communities demonstrate their commitments to support the activities of mobile brigades and shelters for women subjected to violence at the expense of their own resources. In particular, according to the decision of the session of the Kharkiv City Council, the financing of the shelter in Kharkiv has been carried out at the expense of the local budget 
since November 2017. It is also expected that the shelter and mobile brigade in Mariupol will be transferred to the city balance from January 1, 2019.

The important response to domestic violence is provided by the National Hotline to Prevent Domestic Violence, Human Trafficking and Gender-based Discrimination and the National Children's Hotline, operated by La Strada - Ukraine ${ }^{5}$. The consultants of these hotlines provide day-and-night information, legal and psychological support to the survivors of violence, information and training support to the police officers. In 2017, the National Hotline received 33 thousand calls, of them $92 \%$ (almost 30 thousand calls) concerned domestic violence. In response to these requests, 20,539 informational consultancies, 6,286 psychological consultancies, and 2,174 legal consultancies were provided to the citizens. As to children, they are not only survivors, but they also may witness some acts of domestic violence in their families. According to the consultants, most children do not call the hotline by themselves, but rather their relatives, neighbours or friends. In 2017, there were 2,172 calls received by the Child's Hotline, that is almost twice as much as in $2016(1,187$ calls, respectively).

To address the challenges related to domestic violence, a special pilot project entitled Police Network against Domestic Violence ("POLINA") was launched to implement the new forms of response to domestic violence in June of 2017. The first mobile groups of POLINA started to operate in three locations (Darnytsia Department of the Main Department of the NPU in Kyiv city, Malynovskyi Department of Police in Odesa city and Sievierodonetsk Department of Police in Lugansk oblast). During the first month after the start of the project, the law enforcement officers received 376 appeals in the pilot regions and issued 115 administrative protocols and four criminal proceedings against the perpetrators of violence.

Since the start of work, 4,253 calls related to domestic violence were responded by the mobile groups, including 611 responses realized in cooperation with social workers. During this period, there were 2,015 prophylactic conversations conducted, 1,608 administrative protocols issued in accordance with Article 173-2 of the CoUAO . Based on the investigation of complains and appeals on domestic violence, 62 criminal proceedings were initiated. In addition, there were more than 500 positive feedback calls received by the National Hotline on Domestic Violence. Taking into account the positive outcomes of implementation of the pilot project on response to domestic violence, it is planned to introduce the police mobile groups in all administrative centers of the regions of Ukraine and in such cities as Kyiv, Kramatorsk, Sloviansk, Mariupol, Sievierodonetsk, Bila Tserkva and Berdyansk.

Finally, the MoJ plans to set up a network of the specialized centers of providing free legal support in case of domestic violence. Two such centers have been already established in Kyiv to provide support of the skilled lawyers with specialization in domestic violence issues. The centers have contacts of social service providers and non-governmental organizations that provide additional assistance to the survivors of domestic violence.

Conclusions and recommendations. Therefore, a lot of efforts have been paid to establish a comprehensive system of prevention-and-response to domestic violence in accordance with the international standards and best practices. Still, some recommendations may be relevant for improving approaches to combating domestic violence at the institutional level:

1) to the National Police of Ukraine:

- facilitate efforts to finalize the normative acts that regulate all levels of the police response to domestic violence, including the procedure of risk assessment in the framework of EPO use, the procedure of putting perpetrators of violence in the Registry

\footnotetext{
5 http://www.la-strada.org.ua/ucp_mod_library_showcategory_58.html
} 
on Prevention Activities due to Domestic Violence, the standards of the prophylactics work with perpetrators of domestic violence to avoid any possible inconsistency and ambiguity of interpretation;

- ensure the development of clear and comprehensive information (instructions, recommendations, etc.) on the procedures for using new tools of protection in case of domestic violence. The information should explain the priorities of the EPO (safety of a victim), articulate the rule of law in terms of police powers to restrict the perpetrator's housing rights, and procedures to follow in terms of other problematic issues;

- scale-up training of police officers on prevention and response to domestic violence and ensure comprehensive coverage in all regions. The training should address:

- identifying the forms of domestic violence (an identification charts could be developed to classify the situations of violence);

- working out the proper filing of the administrative protocols in situations of domestic violence;

- practical issues of using the EPO and the risk assessment approaches;

- transforming negative stereotypes toward domestic violence and victim-blaming attitudes, and

- promoting conflict mediation skills and making safety plans for survivors of domestic violence;

- the novelties of the $\mathrm{CCoU}$ should be paid particular attention to in terms of training for police investigators, experts, etc. The principal focus of clarification should address new definitions of sexual violence, understanding of the aggravating circumstances of criminal offenses, and approaches to systematically classify a domestic violence crime as such;

- improve the internal communication and coordination between different police units to provide information exchange about new ways of responding to domestic violence, in particular the outcomes of the POLINA pilot project;

- revise the system of data collection and processing in terms of domestic and genderbased violence, as administrative data of the NPU would provide the base for the future databank on domestic violence;

2) to social and support service providers, local executive powers, and NGOs:

- actively participate in the development of new standards, methodologies and approaches in providing support to survivors of domestic violence with regard to the new norms of the Law on Domestic Violence;

- initiate the activities of interdepartmental working groups on the response to domestic violence to identify the gaps in coordination at the local level and develop some practical recommendations on the capacity-building of local service-providers;

- facilitate the efforts on training the well-skilled experts in the field of domestic violence response, including psychologists, mediators, social workers, lawyers, medical workers. Presently, there are plenty of opportunities of distant learning based on internet platforms, on-line training courses, workshops and public events to improve the knowledge and practical skills in dealing with response to domestic violence;

- take the leadership in the population awareness raising campaigns on the new norms of the Law on Domestic Violence and available services; however, a responsible attitude should be observed in terms of providing reliable and correct information to avoid public disappointments and the low level of trust in local authorities; 
- work intensively on transforming the persistent harmful attitudes toward domestic violence and promote zero tolerance toward violence in society and unbiased attitudes toward victims;

- given the permanent lack in resources and limited funding allocated to public service-providers, it is important to develop innovative approaches to fundraising and project management in close cooperation with NGOs, including submitting of project proposals to the public budgets. There are multiple successful initiatives of community policing at the local level that address some specific gaps and facilitate institutional capacity building, so the expertise of NGOs and public activists should be applied in the work of public service-providers as well;

- prioritize the equal access to the comprehensive system of response services for all population groups, including socially vulnerable women and men, disabled and elderly people, and develop targeted approaches to assist people with mental illness who were subjected to domestic violence.

\section{REFERENCES}

1. Levchenko, K., Legenka, M. and others (2017). Criminal Justice Practice and Violence against Women. Assessment of the Readiness of the Ukrainian Criminal Justice System to Implement the Principles of the Istanbul Convention, DCAF, La Strada - Ukraine. Kyiv, Agency-Ukraine.

2. Levchenko, K. and Legenka, M. (2015). Powers of Health Care Authorities in Implementing the Work in the Area of Preventing Domestic Violence. Journal of Criminological Association, Vol. 2 (10): 194-195.

3. Kalashnyk, O., Wills, E. (2018). Combating Domestic Violence. Practical Guidelines for Police Officers. Project of Council of Europe «Combating Violence against Women and Children in Ukraine», Kyiv.

4. Khrystova, G. (2014). State positive obligations and due diligence in human rights and domestic violence perspective. Evropsky politicky a pravni diskurz, Vol. 1, Iss. 5: 109-122.

5. Demchenko, I. (2014). Report on the Findings of a Survey 'Availability of Social Services for the Women Who Have Suffered Violence', supported by UNFPA in partnership with MoSP, Kyiv.

6. Recommendations for the Ministry of Social Policy of Ukraine on the Strategic Approach for Raising a Population awareness (n.d.). Project of Council of Europe «Combating Violence against Women and Children in Ukraine».

7. Protection of Children against Sexual Exploitation and Abuse. Technical-economic grounds of testing Barnahus model in Ukraine (2018), Council of Europe.

8. Ukraine Multiple Indicator Cluster Survey -2012 (2013). State Statistics Service, Kyiv.

9. Economic Costs of Violence against Women in Ukraine (2017). UCSR, UNFPA.

10. Masculinity Today: Men's Attitudes to Gender Stereotypes and Violence Against Women (2018). UNFPA, UCSR.

Стаття надійшла до редакції 03.05.2019.

Article submitted on 03.05.2019. 


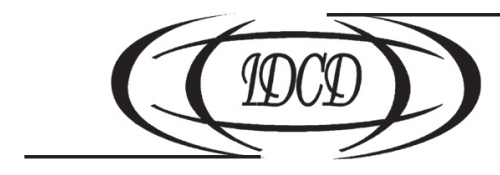

https://doi.org/10.15407/dse2019.02.023

УДК 314.146

JEL CLASSIFICATION: J13

\section{С.Ю. АКСЬОНОВА}

канд. екон. наук, пров. наук. співроб.

Інституту демографії та соціальних досліджень

ім. М.В. Птухи НАН України

01032, Україна, м. Київ, бул. Т. Шевченка, 60

E-mail: Svitlana_Aksyonova@yahoo.com

ORCID 0000-0003-0516-9078

\section{ВЗАЕМОЗВ'ЯЗКИ СЕРЕДНЬОГО ВІКУ МАТЕРІ ПРИ НАРОДЖЕННІ ДИТИНИ І РІВНЯ НАРОДЖУВАНОСТІ}

Демографи висловлюють різні точки зору щодо впливу відкладання дітонародження на старший вік жінок на рівень народжуваності у країні. Метою даного дослідження стало з'ясування характеру взаємозв'язку середнього віку матері при народженні дитини і рівня народжуваності в Україні в останнє півстоліття і порівняння з особливостями такого взаємозв'язку в розвинених європейських країнах. У дослідженні використано статистичні дані про народжуваність в умовних і реальних поколіннях жінок із міжнародної Бази даних Hитап Fertility Database. За допомогою графічного методу вперше виокремлено і досліджено чотири етапи (фази) у змінах зв'язку віку материнства і рівня народжуваності, котрі спостерігаються в європейських країнах, статистичні матеріали яких дають змогу прослідкувати динаміку зазначених показників у відносно тривалий проміжок часу для умовних поколінь. Відмічено схожість конфігурацій графіків зв'язку рівня народжуваності та середнього віку матері при народженні дитини (як первістка, так й усіх черговостей народження), побудованих для різних європейських країн. Уході дослідження підтверджено, що зниження рівня народжуваності не обов'язково пов'язано з відкладанням дітонародження. З'ясовано, що зміна середнього віку матері при народженні дитини може відбуватися у періоди відносної стабілізації інтенсивності народжуваності, зміни сумарного показника народжуваності можуть не супроводжуватися змінами середнього віку матері при народженні дитини, а різні вікові профілі народжуваності можуть продукувати однакові показники середнього віку матері при народженні дитини. У статті розглянуто вплив змін віку материнства на календарні показники народжуваності за допомогою темпоефекту. На нашу думку, різні «сценарії зв'язку змін вичерпаного коефіцієнту плідності (у нашому дослідженні на момент досягнення когортою 40 років) і середнього віку матері при народженні дитини у реальних поколіннях можна пояснити різним часом початку $i$ різною швидкістю перебудови окремих елементів (складових) дітородної поведінки.

Ключові слова: народжуваність, материнство, середній вік матері при народженні дитини, середній вік матері при народженні першої дитини, реальні та умовні покоління. 


\section{С.Ю. Аксёнова}

канд. экон. наук, вед. научн. сотруд.

Институт демографии и социальных исследований

им. М.В. Птухи НАН Украины

01032, Украина, г. Киев, бул. Т. Шевченко, 60

E-mail: Svitlana_Aksyonova@yahoo.com

ORCID 0000-0003-0516-9078

\section{ВЗАИМОСВЯЗИ СРЕДНЕГО ВОЗРАСТА МАТЕРИ ПРИ РОЖДЕНИИ РЕБЕНКА И УРОВНЯ РОЖДАЕМОСТИ}

Демографы высказывают разные точки зрения относительно влияния откладывания рождения детей на старший возраст женщин в целом на уровень рождаемости в стране. Цель данного исследования - определение характера взаимосвязи среднего возраста матери при рождении ребенка и уровня рождаемости в Украине за последние полвека и сравнение с особенностями такой же взаимосвязи в развитых европейских странах. В исследовании использованы статистические данные о рождаемости в условных и реальных поколениях женщин международной Базы данных Huтаn Fertility Database. Cnoмощью графического метода впервые выделены и исследованы четыре этапа (фазы) в изменениях связи возраста материнства и уровня рождаемости, наблюдаемые в европейских странах, статистические материалы которых дают возможность проследить динамику этих показателей в относительно длительный промежуток времени для условных поколений. Отмечено сходство конфигураций графиков связи уровня рождаемости и среднего возраста матери при рождении ребенка (как для первенцев, так и для всех очередностей рождения), построенных для разных европейских стран. В ходе исследования подтверждено, ито снижение уровня рождаемости не обязательно связано с откладыванием деторождения. Установлено, что изменение среднего возраста матери при рождении ребенка может происходить в периоды относительной стабилизации интенсивности рождаемости, изменения суммарного показателя рождаемости могут не сопровождаться изменениями среднего возраста матери при рождении ребенка, а разные возрастные профили рождаемости могут продуцировать одинаковые показатели среднего возраста матери при рождении ребенка. Рассмотрено влияние изменений возраста материнства на календарные показатели рождаемости с помощью темпоэффекта. По нашему мнению, различные «сценарии» связи изменений когортного показателя рождаемости (в этом исследовании на момент достижения когортой 40 лет) и среднего возраста матери при рождении ребенка в реальных поколениях можно объяснить разным временем начала и разной скоростью перестройки отдельных элементов (составляющих) детородного поведения, на что, в свою очередь, повлиял комплекс разнообразных социально-экономических и политических факторов.

Ключевые слова: рождаемость, материнство, средний возраст матери при рождении ребенка, средний возраст матери при рождении первого ребенка, реальные и условные поколения.

\section{S.Yu. Aksyonova}

$\mathrm{PhD}$ in Economics, Leading scientific worker

Ptoukha Institute for Demography and Social Studies

of the National Academy of Sciences of Ukraine,

01032, Ukraine, Kyiv, Taras Shevchenko Blvd., 60

E-mail: Svitlana_Aksyonova@yahoo.com

ORCID 0000-0003-0516-9078

\section{THE RELATION OF THE MEAN AGE OF WOMEN AT CHILDBEARING AND FERTILITY RATE}

Demographers express different points of view on how postponement of childbirth at older age of women affects fertility rate in the country. The purpose of this paper is to find out the character of relation between the mean age of women at childbearing and fertility rate in Ukraine in the last half century and comparison with the peculiarities of such relationship in developed European countries. The study used the statistical data on period and cohort fertility from the International Database of Human Fertility Database. The use of graphical method allowed defining four stages (phases) of the relationship between the mean age at childbearing and fertility rate. These stages are distinguished and investigated in European countries where the statistical data are sufficient to trace the dynamics of fertility indicators in a relatively long time period. The similarity of the configurations 
of the graphs of relation between the mean age of women at childbearing and fertility rate (both the first order, and all birth orders) constructed for different European countries is noted. In the course of the study, it was confirmed that decline of the birth rate is not necessarily caused by postponement of childbirth. It is found that the change in the mean age of women at childbearing can occur during periods of relative stabilization of fertility, and changes in the total fertility rate may not be accompanied by changes in the mean age of motherhood. The article examines the influence of changes in the mean age of women at childbearing on the period fertility rate using tempo-effect. In our opinion, different "scenarios" of the relation of completed cohort fertility changes (in some cases - fertility by age 40) and cohort mean ages at birth by birth order can be explained by different time of onset and different rates of restructuring of individual elements (constituents) of childbearing behavior, which, in turn, was influenced by complex of diverse socio-economic and political factors.

Keywords: fertility; motherhood; advanced maternal age, mean age at childbearing, mean age at birth of the first child, period and cohort fertility.

Постановка проблеми та аналіз наявних досліджень. Дослідження середнього віку матері при народженні дитини в умовних і реальних поколіннях, з'ясування відмінностей динаміки показника у нашій країні та розвинутих європейських країнах засвідчили, що підвищення віку материнства в Україні розпочалося на два десятиріччя пізніше, ніж у більшості країн Західної Свропи. Процес постаріння материнства / батьківства в Україні відбувається вже протягом двох десятиріч, що уможливлює вивчення причин і наслідків зазначеного процесу та характеру взаємозв'язків між ним і іншими демографічними тенденціями чи характеристиками. Зокрема, хвилює таке питання: як зміщення народжуваності на старші репродуктивні групи жінок впливає на сумарну / вичерпану народжуваність. Д.М. Едієв (D.M. Ediev) вважає, що середній вік матері при народженні дитини є важливим індикатором моделі народжуваності, оскільки безпосередньо пов'язаний із довжиною покоління, а у короткостроковій і середньостроковій перспективі саме прямий ефект від зміни довжини покоління призводить до «ущільнення» або «розрідження» розміщення народжень уздовж осі часу та є визначальним у зміні динаміки чисел народжень і чисельності населення у ході зміни календаря народжень [1].

У свій час Р. Сіфман (R. Siffmann) звертала увагу, що чим коротше покоління, тим швидші темпи відтворення населення. Поряд із цим вчений зазначала, що між зниженням віку матері при народженні дитини і величиною приросту населення може бути й зв’язок протилежного характеру, оскільки зниження віку матері при народженні дитини часто є не лише результатом зміщення народжень від старших фертильних груп жінок до молодших, а й відбувається через скорочення інтенсивності народжуваності у старшому віці [2, с. 108-109]. У цілому, за результатами досліджень Р. Сіфман, виконаних на статистичних даних 1960-х років, зниження народжуваності охопило насамперед жінок старшого репродуктивного віку, на які припадала основна частка народжень дітей високих черговостей, і ознаменувало прискорення переходу до малодітності.

Існує думка, що підвищення рівня народжуваності супроводжується збільшенням середнього віку матері при народженні дитини (усі черговості), оскільки підвищення пов’язано здебільшого із народженням дітей вищих черговостей народження, які, як правило, мають місце у жінок старшого репродуктивного віку, отже зниження народжуваності, зазвичай пов'язане із підвищенням частки народжень нижчої черговості (відповідно, в молодому віці), впливає у зворотному напрямі [3].

У дослідженнях методів удосконалення оцінки рівня народжуваності для умовних поколінь П. Шевчук (P. Shevchuk) зауважував важливість вивчення змін середнього віку матері для динаміки народжуваності та запропонував шляхи елімінування цього 
фактору, що «дозволило б обчислити рівень народжуваності за умови незмінного середнього віку матері» [4].

T. Фрейка (T. Frejka) на основі емпіричних досліджень когортної та календарної трансформації народжуваності у розвинених країнах, статистичні дані яких були доступними, розробив модель взаємодії відкладання народжень і рекуперації, виокремивши чотири фази [5]. Модель розглядає зміни накопиченого календарного показника народжуваності для жінок віком 15-28 років, накопиченого календарного показника народжуваності для жінок віком 29-49 років, календарного сумарного показника народжуваності та вичерпаної плідності з лагом у 30 років, але оминає аналіз змін, які відбувалися у кожній із фаз із показником середнього віку матері при народженні дитини. Отже, у нашому дослідженні вперше було зосереджено увагу на фазах (етапах) змін зв’язку середнього віку матері при народженні дитини і рівня народжуваності, що можна простежити в європейських країнах, статистичні матеріали яких допомогають прослідкувати динаміку цих показників у відносно тривалий проміжок часу для умовних поколінь. У моделі Т. Фрейка (Т. Frejka) відлік починається з часу поширення у тій чи іншій країні відкладання народжень. Запропоноване дослідження охоплює й період омолодження материнства, адже важливо знати характер зв'язку між середнім віком матері при народжені дитини і рівнем народжуваності за раннього початку дітородної діяльності.

У іншому дослідженні Т. Фрейка та Ж.-П. Сардон (Т. Frejka \& J.-P. Sardon), досліджуючи довгострокові зміни середнього віку матері при народженні першої дитини у реальних когортах у розвинутих країнах Свропи, дійшли висновку, що за інших рівних умов відкладання перших народжень залишає менше можливостей для народження дітей більших черговостей [6] і тому впливає на число народжень та сумарні показники народжуваності когорт.

В останнє п’ятиріччя в Україні відбувається падіння рівня народжуваності, водночас продовжується підвищення віку материнства, тому дослідження взаємозв'язків цих процесів є актуальним для нашої країни.

Попередні наші дослідження показали, що підвищення середнього віку матері при народженні дитини відбувалося у народженнях усіх черговостей, але зі збільшенням черговості народження темпи підвищення показника уповільнювалися.

Основною метою даного дослідження є з'ясування характеру взаємозв'язку середнього віку матері при народженні дитини і рівня народжуваності в Україні в останнє півстоліття і порівняння його з особливостями такого взаємозв'язку в розвинених європейських країнах.

Виклад основного матеріалу. Аналіз взаємозв'язку рівня народжуваності та середнього віку материнства здійснено на статистичних даних про народжуваність умовних і реальних поколінь жінок з міжнародної Бази даних Human Fertility Database (HFD) [7], яку підтримує Інститут демографічних досліджень ім. Макса Планка (Німеччина). У роботі залучено наявні повні дані для всього інтервалу репродуктивних вікових груп 15-49 років поколінь, народжених до 1965 р., а також неповні дані (лише на момент досягнення когортою 40 років) про фактичну народжуваність молодших поколінь, для усього загалу народжених і за сукупностями дітей певних черговостей народження.

Основним методом дослідження було обрано графічний метод, який себе зарекомендував як важливий та ефективний інструмент у вивченні взаємозв'язків соціальних явищ і процесів у динаміці. Для кожної країни було побудовано графік залежності інтенсивності народжуваності від змін середнього віку матері при народженні дитини. Зважаючи на те, що більш адекватною характеристикою зрушень у 
календарі народжень є середній вік матері при народженні первістка, основну увагу спрямовано саме на цей показник. На жаль, статистичні матеріали багатьох країн не дають змоги побудувати показові ряди календарної або когортної народжуваності за черговістю народжуваності (за черговістю народження відсутні дані у Франції, Італії (когорти), Німеччині (когорти), занадто короткі або непоказові ряди календарної (Італія, Німеччина) та когортної (Іспанія, Австрія, Норвегія, Фінляндія) народжуваності за черговістю народження), у таких випадках розглянуто загальну (для усіх черговостей) народжуваність.

Аналіз змін рівня народжуваності залежно від змін середнього віку матері при народженні дитини в умовних поколіннях виявив такі особливості:

1. Зниження рівня народжуваності не обов'язково є наслідком відкладання народження дитини [8] і може відбуватися у періоди омолодження материнства: в Україні на початку 1990-х років середній вік матері при народженні першої дитини знижувався одночасно із суттєвим падінням рівня народжуваності. У період 1987-1992 рр. середній вік матері при народженні дитини (усі черговості) знизився майже на один рік, дещо повільніше «омолоджувався» середній вік матері при народженні первістка - на 0,4 року, водночас інтенсивність народжуваності скоротилася на $21 \%$.

2. Зміна середнього віку матері при народженні дитини також може відбуватися у періоди відносної стабілізації інтенсивності народжуваності. В Україні у другій половині 1960-х рр. і першій половині 1970-х рр. календарний показник сумарної народжуваності коливався у межах 2,0-2,1 дитини у розрахунку на одну жінку, а середній вік матері при народженні дитини (як первістків, так й усіх черговостей) за це десятиріччя знизився на один рік. У 2008-2012 рр. за майже незмінного сумарного показника відбулося зростання середнього віку матері при народженні первістка на 0,4 року.

3. Зміна сумарного показника народжуваності може не супроводжуватися змінами середнього віку матері при народженні дитини. В Україні впродовж 19921996 рр. середній вік матері при народженні первістка майже не змінювався (зниження середнього віку матері при народженні дитини з врахуванням усіх черговостей народження також було неістотним), а от дітородна активність продовжувала стрімко падати - з 1,67 до 1,34 дитини на одну жінку.

4. Відкладання дітонародження на старший вік може супроводжуватися зростанням рівня народжуваності. В Україні на початку нового тисячоліття підвищення середнього віку матері при народженні первістка супроводжувалося зростанням дітородної активності (за десять років, з 2002 р. до 2012 р., середній вік матері при народженні первістка зріс на 1,4 року і на 40 \% піднявся сумарний показник народжуваності (рис. 1).

Незважаючи на різні динамічні ряди в європейських країнах, можна побачити схожість конфігурацій графіків взаємозв'язку рівня народжуваності та середнього віку матері при народженні дитини (рис. 2, 3). Загалом можна виокремити чотири етапи змін зв'язку віку материнства та рівня народжуваності.

На периому етапі - зменшення віку початку дітородної активності може супроводжуватися як незначними коливаннями календарного сумарного показника народжуваності, так й відносно невеликим його зниженням або зростанням. Зокрема, у Нідерландах омолодження материнства у 1953-1961 рр. супроводжувалося незначним збільшенням рівня народжуваності, а у 1963-1971 pp., навпаки його зниженням. 


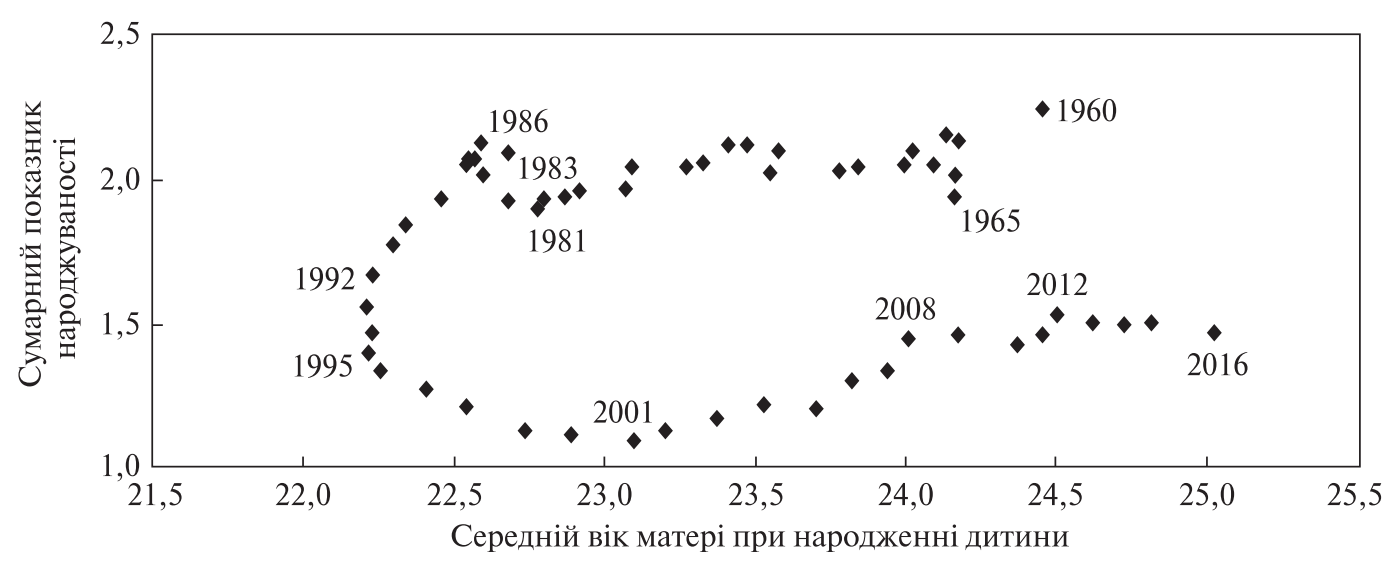

Рис. 1. Сумарний показник народжуваності залежно від середнього віку матері при народженні первістка в Україні

Джерело: розрахунки автора за даними Державної служби статистики. Середній вік матері при народженні дитини обчислено за віковими коефіцієнтами народжуваності, а не за числами народжених, тому можливі розходження з показниками Державної служби статистики.

За статистичними даними Норвегії можна простежити, що до 1972 р. падіння сумарного показника народжуваності відбувалося разом зі зменшенням середнього віку матері при народженні первістка. У Португалії події подібно розвивались 3 1964 р. до 1974 р., у Чехії - до 1960 р. Також можна помітити уповільнення темпів омолодження материнства.

На другому етапі - середній вік матері при народженні першої дитини змінюється неістотно (майже стабілізується), а от сумарний показник народжуваності стрімко падає і практично відразу ж після досягнення певного рівня низької народжуваності починається поступове підвищення віку материнства (при цьому в ранньому репродуктивному віці скорочення народжуваності відбувається випереджальними темпами). Цей етап порівняно нетривалий, але й тут існують варіації. У Нідерландах, наприклад, протягом 1969-1973 рр. календарний показник народжуваності знизився на 30 \%, тоді як середній вік матері при народженні первістка, залишався практично однаковим. Період, коли рівень народжуваності зменшувався без істотних змін середнього віку матері при народженні первістка спостерігався й у Португалії, але тривав майже десятиріччя (1976-1985). В Естонії у 1989-1994 рр. середній вік матері при народженні первістка коливався у межах 22,6-22,8 років, а от інтенсивність народжуваності стрімко знижувалася й у 1995 р. на 40 \% була меншою за рівень 1988 р. У Чехії наприкінці 1960-х рр., протягом 1970-х і 1980-х років середній вік початку дітородної діяльності для жінок був у межах 22,3-22,5 років, а сумарний показник народжуваності після зростання на 31 \% у період 1968-1974 pр., починаючи з 1975 р. і до кінця минулого століття зменшився вдвічі, періоди стрімкого падіння чергувалися із періодами повільних зменшень.

На думку А.Г. Вишневського (А.G. Vishnevsky), «зовнішня стабільність» календарного середнього віку матері при народженні дитини свідчить лише про те, що під час активного перебігу демографічного переходу сукупність жінок дітородного віку вкрай неоднорідна: молоді покоління з новим режимом народжуваності є сусідами з поколіннями, які дотримуються колишньої вікової моделі [9, с. 185-186]. Таке по- 
яснення має сенс, адже, як можна буде переконатися далі, в реальних поколіннях зміни на цьому етапі відбувалися значно швидше, інколи дуже різко.

На третьому етапі відбувається перехід до моделі постаріння материнства, що супроводжується, як правило, зниженням рівня народжуваності. Етап охоплює декілька років. Зокрема, у Нідерландах стійка тенденція до підвищення середнього віку матері при народженні первістка має місце починаючи з 1974 р., а інтенсивність народжуваності продовжувала зменшуватися до 1977 р. У Португалії протягом десяти років - з 1985 до 1995 р. одночасно спостерігалось відкладання народження первістка на старший вік і зниження рівня народжуваності. У Чехії, починаючи з 1994 р.
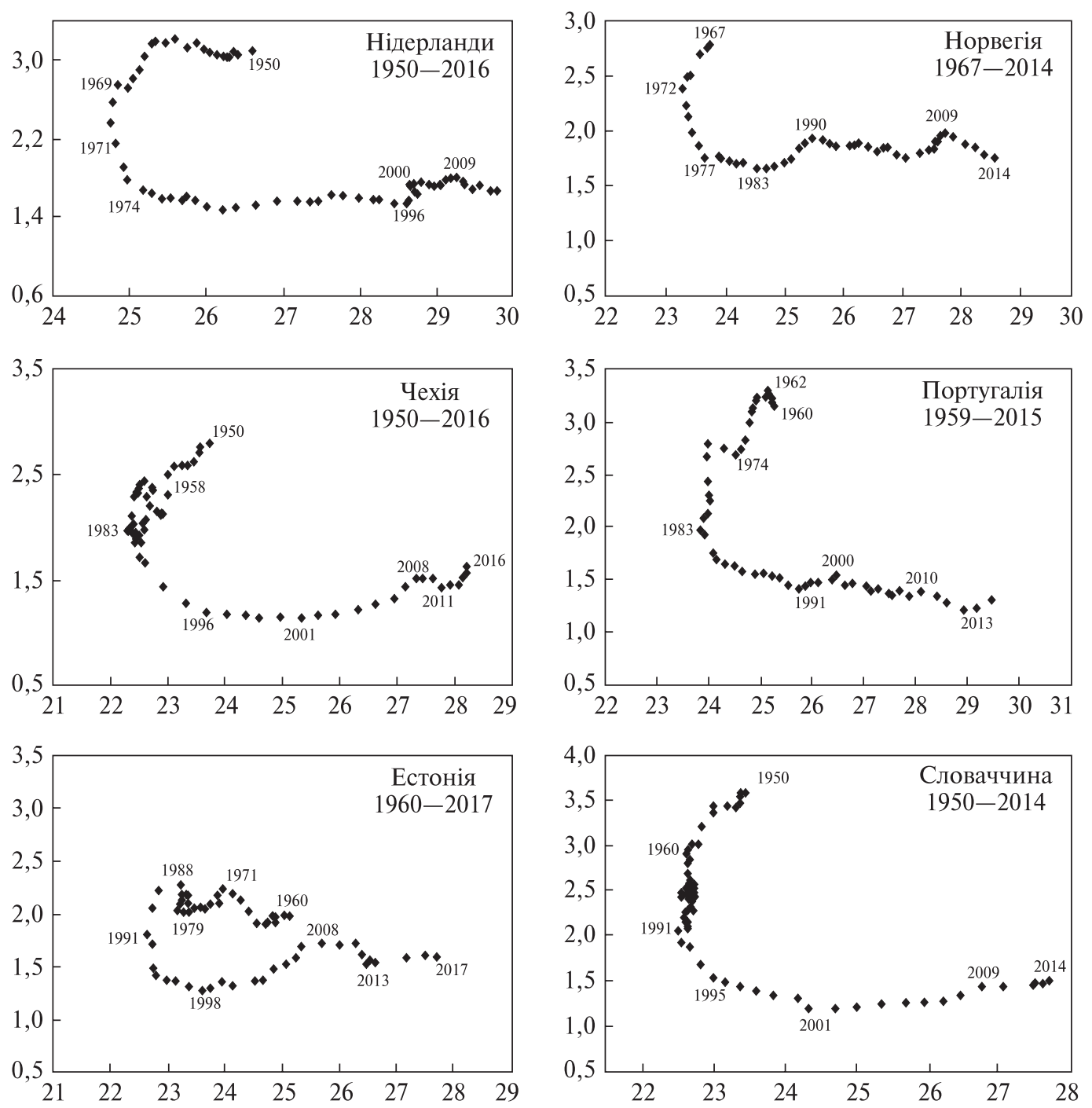

Рис. 2. Сумарний показник народжуваності залежно від середнього віку матері при народженні первістка в Нідерландах, Норвегії, Португалії, Чехії, Естонії, Словаччині, умовні покоління Джерело: за даними Human Fertility Database. 
середній вік матері при народженні дитини (як первістка, так й дітей усіх черговостей народження) невпинно зростає, а от 1991-1997 рр. ознаменувались різким падінням дітородної активності. Подібна ситуація у цей період мала місце й в Естонії, а от в Словаччині тривала довше - до 2001 р.

На четвертому етапі подальше підвищення середнього віку матері при народженні дитини розгортається на тлі підвищення сумарного показника народжуваності або його відносній стабілізації, також можуть відбуватися невеликі коливання інтенсивності народжуваності.

Подібні етапи можна виявити й у випадках, коли до аналізу залучено середній вік матері при народженні дитини (усі черговості) (рис. 3). Необхідно визнати, що перші народження найчіткіше відображають процеси відкладання народжень у молодому віці та їх надолуження у старшому, а відтак й вплив на сумарну народжуваність.
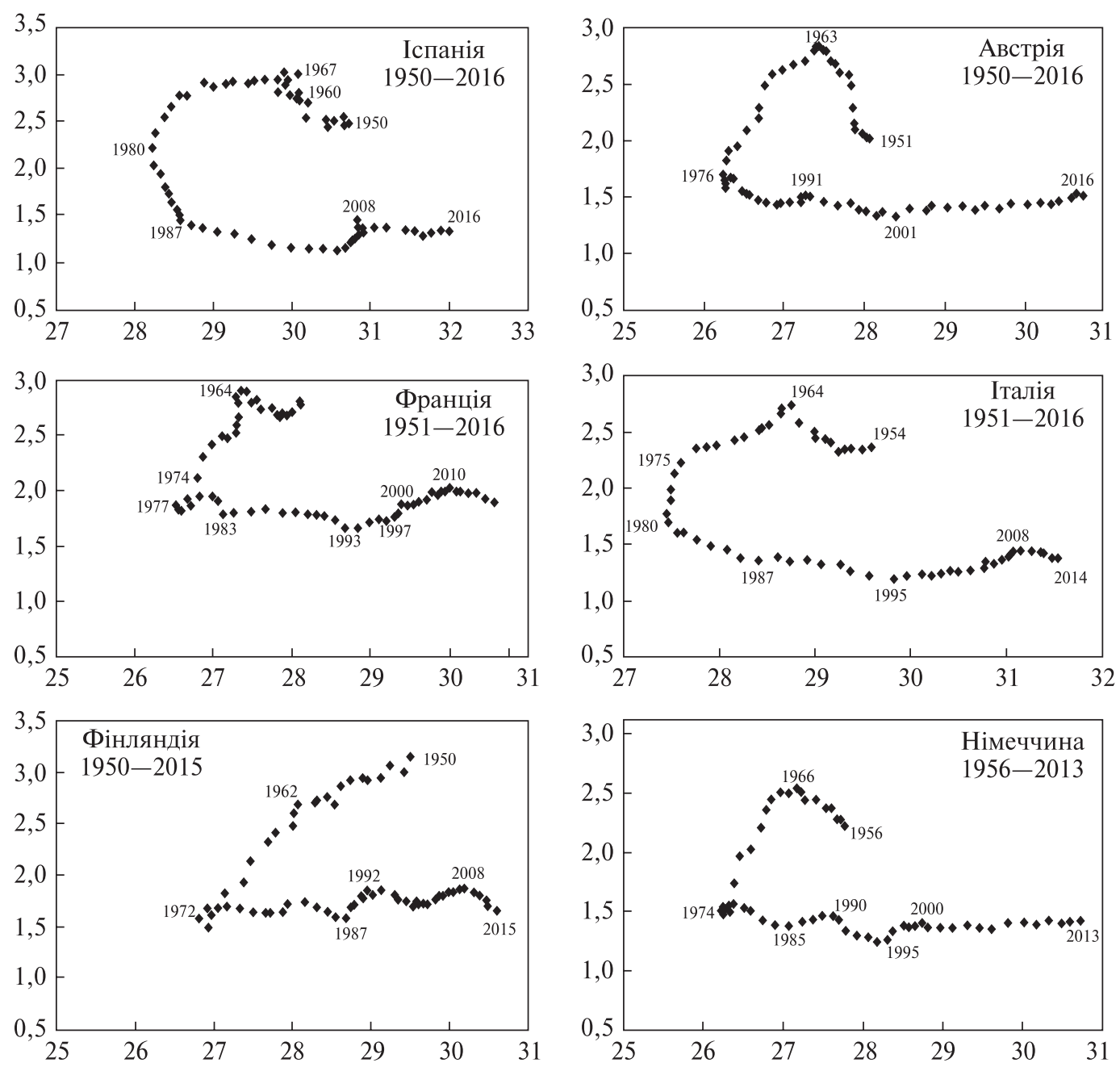

Рuc. 3. Сумарний показник народжуваності залежно від середнього віку матері при народженні дитини (усі черговості) в Іспанії, Австрії, Франції, Італії, Фінляндії, Німеччині, умовні покоління Джерело: за даними Human Fertility Database. 
Однак вивчення взаємозв'язку змін рівня народжуваності та середнього віку матері при народженні дитини (усі черговості) може здійснюватися тоді, коли неважливо, через що саме відбулися зміни останнього: унаслідок відкладання народжень на старший вік чи через перегляд репродуктивних планів у бік зменшення кількості дітей у сім’і.

Вплив змін середнього віку матері при народженні дитини на календарні показники народжуваності (тобто в умовних поколіннях) можна досліджувати за допомогою темпоефекту. Як правило, зниження середнього віку матері зумовлює те, що календарний показник сумарної народжуваності (period TFR) перевищує скоригований показник сумарної народжуваності (AdjTFR), а це свідчить, що якби не відбувалося омолодження материнства, то рівень народжуваності був би нижчий за той, який спостерігався у цей період (в Україні до 1996 р.). Зростання середнього віку матері, навпаки, зумовлює більші значення скоригованого показника сумарної народжуваності (AdjTFR) порівняно із календарним показником сумарної народжуваності без поправок (period TFR). Тобто, якби не було постаріння материнства, то рівень календарної народжуваності був би вищий за той, який маємо [4] (в Україні 1997-2012 рр.) (рис. 4). Однак нас цікавить ще й вектор змін, а от у цьому випадку не все відбувається однозначно. Раніше зазначалося, що у першій половині 1990-х років омолодження материнства супроводжувалося падінням рівня народжуваності; скоригований показник вказує, що якби молоді жінки не поспішали б із народженням дитини, то сумарні показники народжуваності були б дешо нижчими, але також відбувалося би зниження народжуваності. Падіння народжуваності продовжувалося й у 1997-2001 pр. - роки стійкого підвищення віку материнства, коли у практику входило відкладання народження дитини на старший вік. Зокрема, середній вік матері при народженні дитини за цей період зріс на 0,7 року, а сумарний показник народжуваності в умовних поколіннях зменшився на 14,4 \%. Певна стабілізація скоригованого показника сумарної народжуваності (AdjTFR) у ці роки вже була провісником повороту тенденції у бік зростання інтенсивності народжуваності.

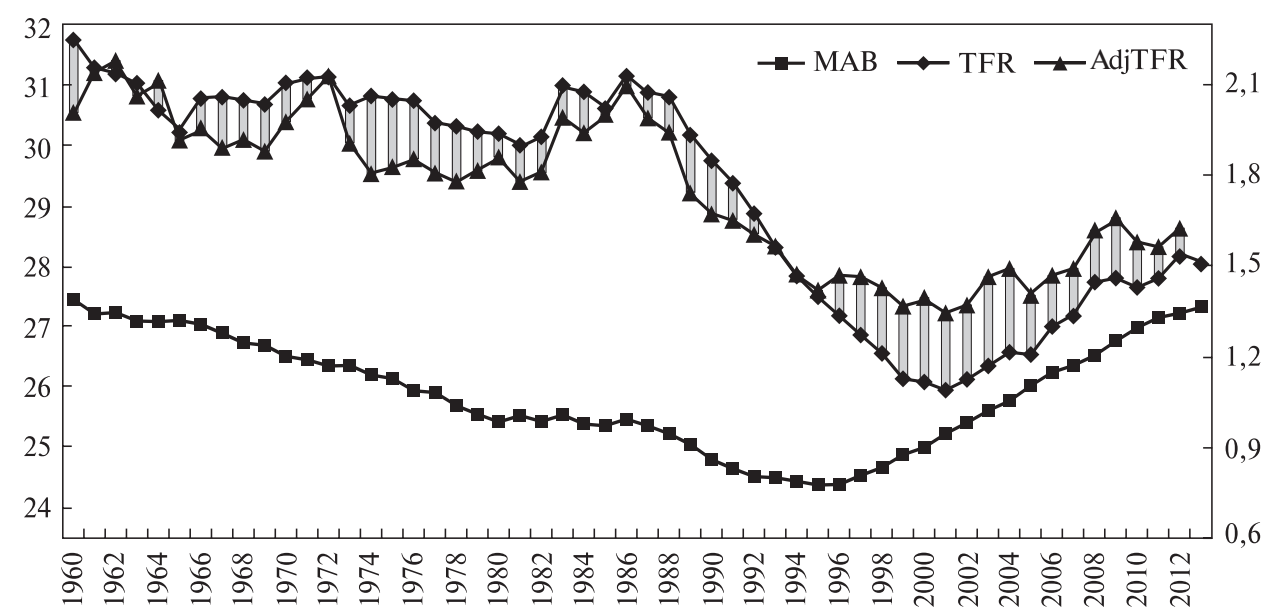

Puc. 4. Сумарний показник народжуваності (TFR), скоригований показник народжуваності з урахуванням «ефекту календаря» $(A d j T F R)$ та середній вік матері при народжені дитини (MAB), Україна, 1960-2013 рp.

Джерело: побудовано за даними Human Fertility Database. 


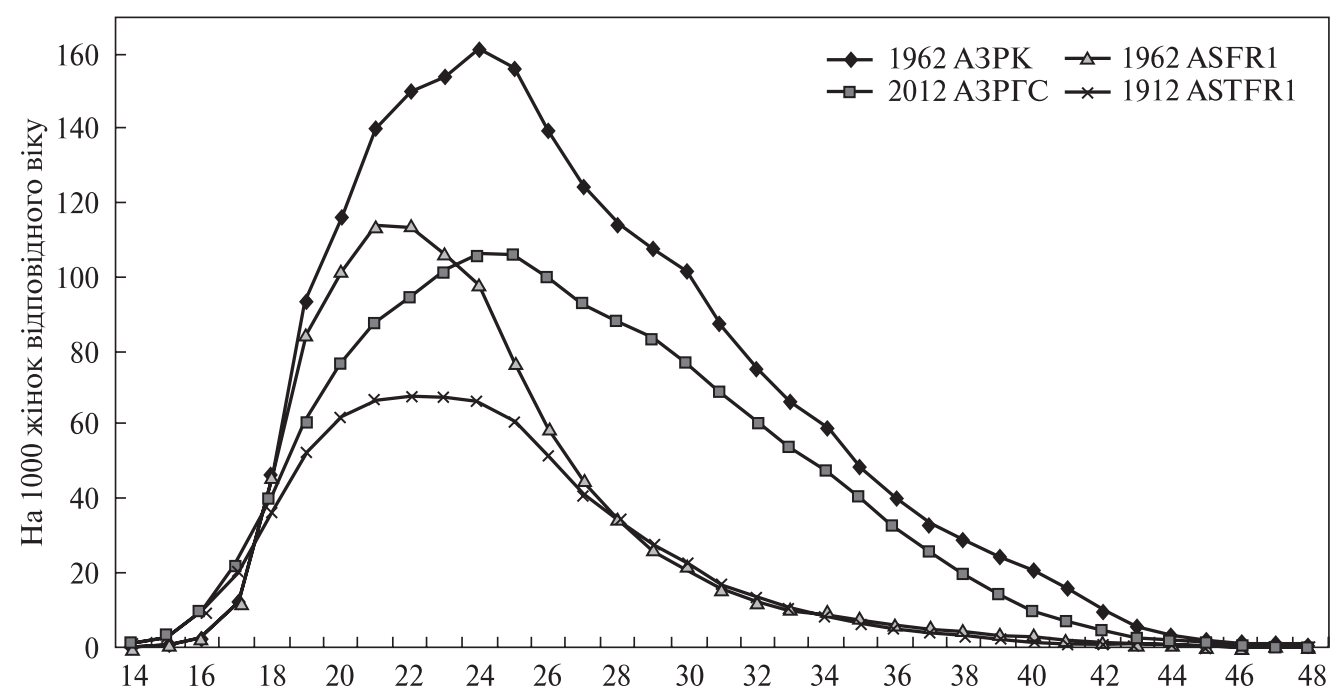

Puc. 5. Вікові коефіцієнти народжуваності (усі черговості - ASFR і первістків - ASFR1) жінок в Україні у 1962 та 2012 рр., на 1000 жінок відповідного віку, \%о

Джерело: побудовано за даними Human Fertility Database.

Доволі цікавим $є$ порівняння вікових профілів народжуваності в умовних поколіннях, в яких середній вік материнства був майже однаковим. Зокрема, в Україні у 1962 р., як і у 2012 р., середній вік матері при народженні дитини становив 27,2 роки, більш того, середній вік матері при народженні первістка мав близькі значення - відповідно 24,5 і 24,2 роки, а от вікові профілі народжуваності є різними (рис. 5).

У наведеному прикладі привертають увагу близькі значення коефіцієнтів народжуваності первістків у жінок віком 27 років і старше у 2012 р. і півстоліття тому, а от дітородна активність молодих жінок у віці 20-24 роки у 1,5-1,7 разів нижча за ту, що була характерною для їхніх ровесниць у 1962 р. Крім того, у новітній демографічній історії важче виявити лідера щодо інтенсивності дітонародження, оскільки різниця між показниками народжуваності у сусідніх вікових групах жінок 20-24 і 25-29 років не така різка, як у минулому столітті.

Календарний показник сумарної народжуваності у 2012 р. - найвищий в Україні у новому тисячолітті - на 28,3 \% був нижчий за аналогічний показник 1962 р. і досягав рівня 1993 р. А от середній вік матері при народженні дитини у 2012 р. перевищував такий показник у 1993 р. на 2,7 роки (при народженні первістка - на 2,3 роки).

Розглянемо профілі вікової народжуваності дітей першої черговості народження 2001 р. - року найнижчої в Україні народжуваності - та 2013 р. - останнього мирного року перед трагічними для країни подіями. Рис. 6 демонструє не лише зменшення інтенсивності народжень первістків у молодих жінок, але й підвищення дітородної активності жінок середнього і старшого репродуктивного віку, у результаті чого віковий профіль народжуваності первістків «зсувається» у бік старших вікових груп. Середній вік матері при народженні першої дитини підвищився за цей період на 1,5 роки (з 23,1 до 24,6 років). Зниження інтенсивності народжуваності первістків у жінок віком 15-23 роки без підвищення дітородної активності у жінок віком 24 і старших зумовило зростання показника до 23,4 роки (тобто лише на 0,3 року). А от зростання інтенсивності народжуваності у жінок віком 24 і старших сприяло підвищенню середнього віку матері при народженні першої дитини на 1,2 роки. 


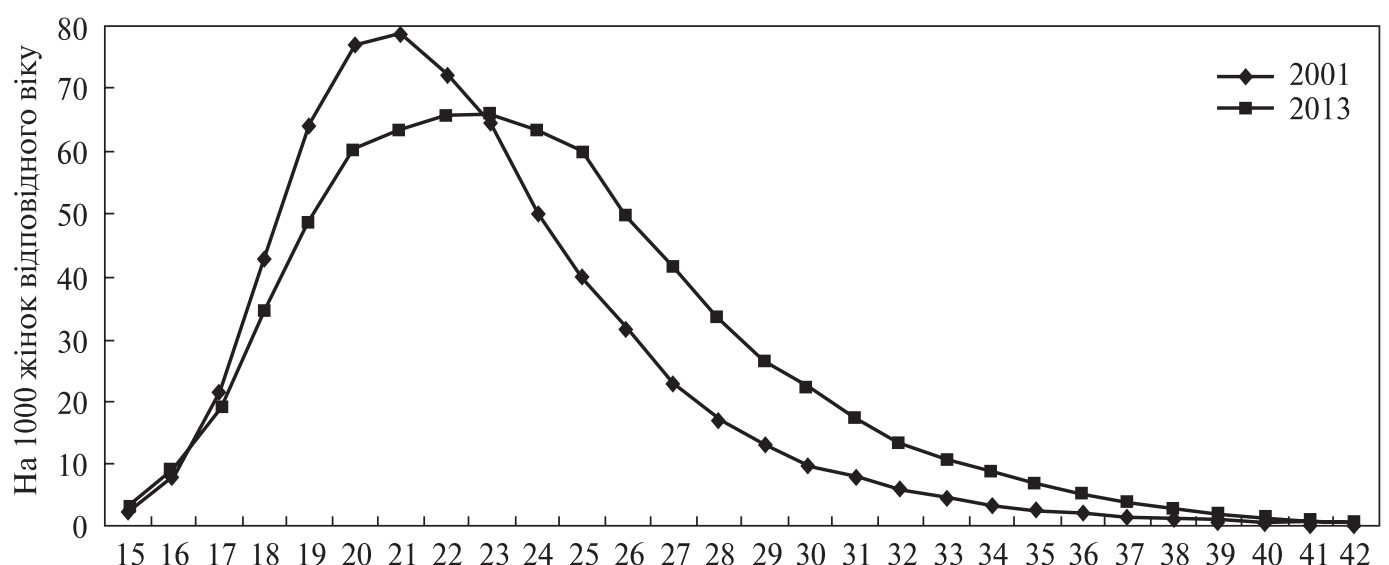

Рис. 6. Вікові коефіцієнти народжуваності первістків в Україні у 2001 та 2013 рр., на 1000 жінок відповідного віку, \%о

Джерело: побудовано за даними Державної служби статистики.

Використання методу реальних поколінь, з одного боку, є досконалішім порівняно з методом умовних поколінь, адже дає уявлення вже про завершений період дітонародження, коли когорти повністю виходять із репродуктивного віку, з іншого боку, статистичні матеріали не усіх країн навіть у Європі дають змогу побудувати показові часові ряди, котрі чітко демонстрували б ту чи іншу тенденцію. Втім, саме метод реальних поколінь дає відповідь на питання: чи може ранній початок дітородної діяльності сприяти підвищенню рівня народжуваності когорти; чи впливає поширення відкладання народжень на старший вік на зниження вичерпаного показника народжуваності когорти?

У практику демографів з метою подовжити часові ряди для детальнішого аналізу середнього віку матері при народженні дитини і сумарного показника народжуваності у реальних поколіннях увійшло використання показників народжуваності для реальних поколінь жінок, які досягли 40 років, що у цілому не може суттєво вплинути на висновки, адже внесок у вичерпану плідність жінок поколінь 1944-1963 pр. народження після того, як вони досягали 40 років, не перевищувала 0,8 \% [10].

На рис. 7 і 8, що показують зв'язок вичерпаного коефіцієнту плідності (на момент досягнення когортою 40 років) і середнього віку матері при народженні дитини, можна побачити когорти, які стали «поворотними» для тенденцій народжуваності. Так, у Нідерландах переломний момент відбувся у когортах 1944-1946 років народження. Ця країна є яскравим прикладом того, що відкладання не обов'язково означає зниження народжуваності, адже відчутне збільшення середнього віку перших народжень у когортах 1950-х років супроводжувалося майже стабільним рівнем народжуваності. Привертають увагу різні темпи підвищення середнього віку матері при народженні первістка в когортах другої половини 1960-х р. н. і когорт 1970-х р. н. в Естонії, тоді як народжуваність у цих когортах залишалася практично на одному рівні.

На жаль, щодо когортної народжуваності у Франції відсутні дані за черговістю народження, але у цілому постаріння материнства у когортах 1950-х років народження відбувалось за майже незмінного вичерпаного коефіцієнта плідності. У Фінляндії когорти 1950-х років народження, а у Німеччині когорти, народженні на початку 1970-х рр., демонструють, що підвищення віку материнства може супроводжуватися 

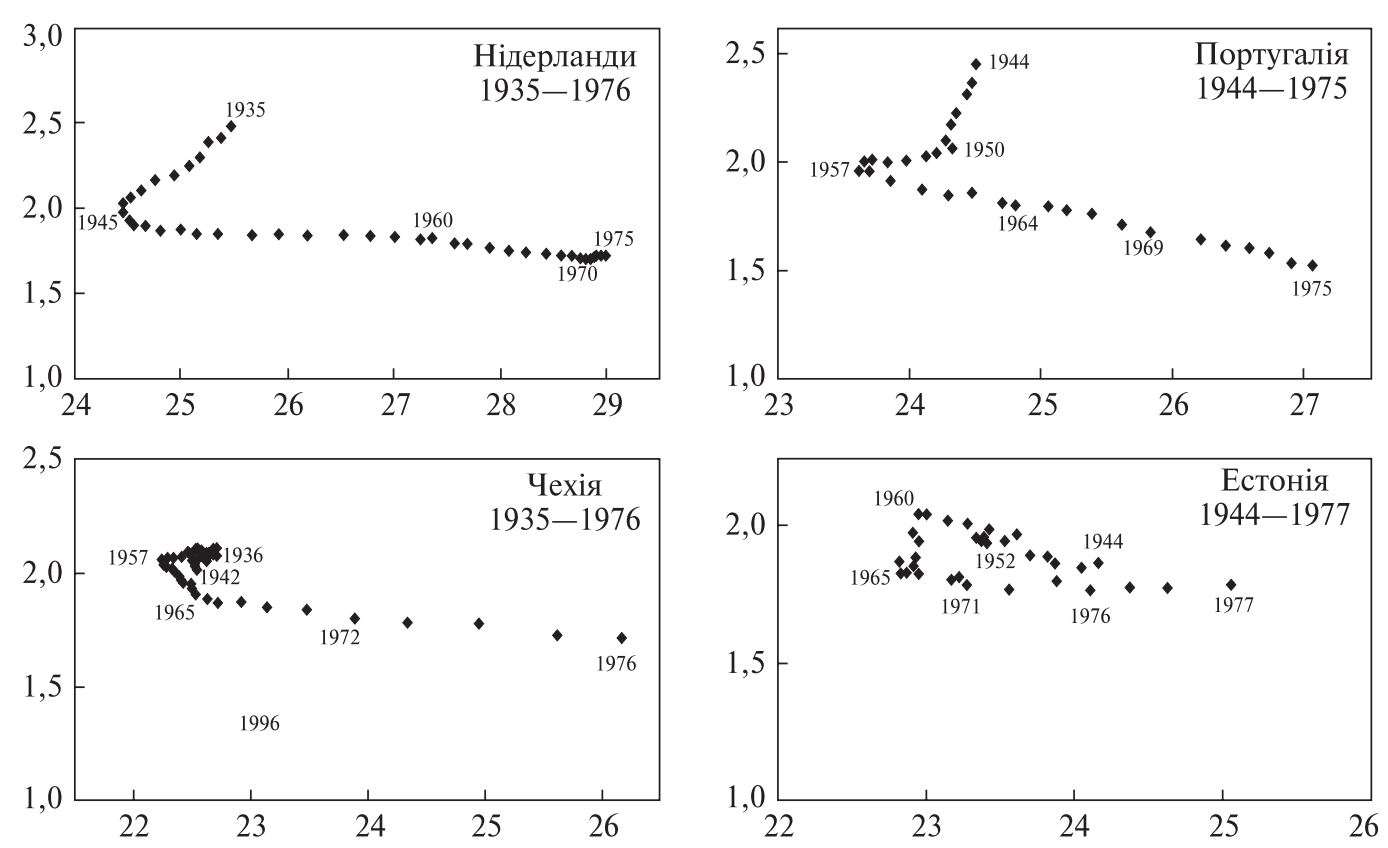

Рис. 7. Вичерпаний коефіцієнт плідності (на момент досягнення когортою 40 років) залежно від середнього віку матері при народженні первістка в деяких країнах Свропи Джерело: за даними Human Fertility Database.

незначним збільшенням рівня народжуваності. Однак у більшості випадків підвищення віку материнства розгортається на тлі зниження народжуваності.

Особливості зв'язку рівня народжуваності та віку матері при народженні дитини / первістка і той факт, що зміни цих показників могли відбуватися як у одному напрямі, так і в протилежних, найімовірніше пояснюються різним часом початку i різною швидкістю перебудови окремих елементів дітородної поведінки. Так, перехід до малодітності розпочався значно раніше, ніж було усвідомлено, що дітородну діяльність необов'язково розпочинати у надто молодому віці. Більш того, сприйняття суспільством раннього початку дітонародження як норми посилило інерційність трансформації вікової структури народжуваності та проявилося як продовження тенденції омолодження материнства у когортах, для яких малодітність вже стала нормою. Визнання того, що сексуальна поведінка є відокремленою від дітородної, а народження дитини у надто молодому віці перешкоджає успішній кар'єрі та позасімейній реалізації жінки, поступово розхитувало суспільні очікування щодо прийнятного віку для дітонародження. Відкладання народжень на старший вік може супроводжуватися подальшим зниженням народжуваності (але, не зумовлювати його), або відбуватися вже на тлі сформованого (можливо лише для певного періоду) рівня дітородної активності. Ефект від зміни довжини покоління, на який вказував Д.М. Едієв [1], якщо й має місце, то в умовних когортах. Наведений раніше висновок Т. Фрейка та Ж.-П. Сардон [6] має сенс лише за умови, що сім'єю було заплановано народження щонайменше трьох дітей. Тоді, зважаючи на ту обставину, що з віком у жінок погіршується репродуктивна функція, а допоміжні репродуктивні технології не в змозі повністю компенсувати природне зниження ймовірності зачаття дитини у 

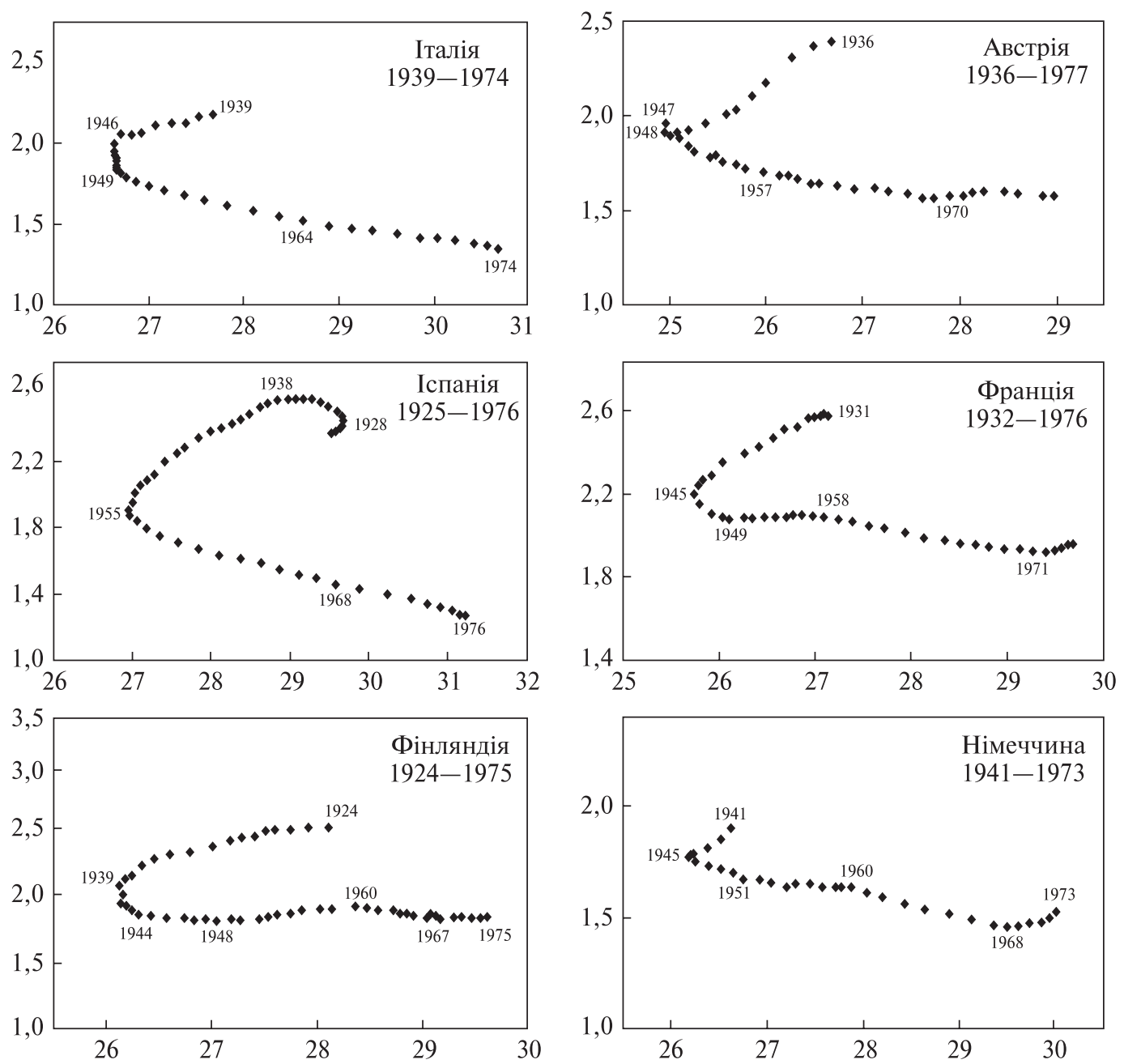

Рис. 8. Вичерпаний коефіцієнт плідності (на момент досягнення когортою 40 років) залежно від середнього віку матері при народженні дитини в деяких країнах Свропи Джерело: за даними Human Fertility Database.

жінки після 35 років [11], цілком логічно припустити, що через зміщення народження першої і другої дитини на старший вік дітородні плани щодо третьої дитини, яка, швидше за все, має народитися у жінки вже після 35 років, можуть бути нереалізованими. Однак численні соціологічні обстеження показують, що в Україні молоді люди здебільшого налаштовані на дводітну сім'ю. Як рівень народжуваності, так і вік матері при народженні дитини, є похідними від стратегії репродуктивної поведінки когорт та їхніх можливостей реалізувати дітородні плани.

В Україні також має місце аналогічний патерн зв'язку вичерпаної плідності та середнього віку матері при народженні первістка з тією різницею, що перехід до тенденції підвищення віку материнства відбувся в нашій країні щонайменше на два десятиріччя пізніше, ніж у розвинутих країнах Європи (рис. 9). 


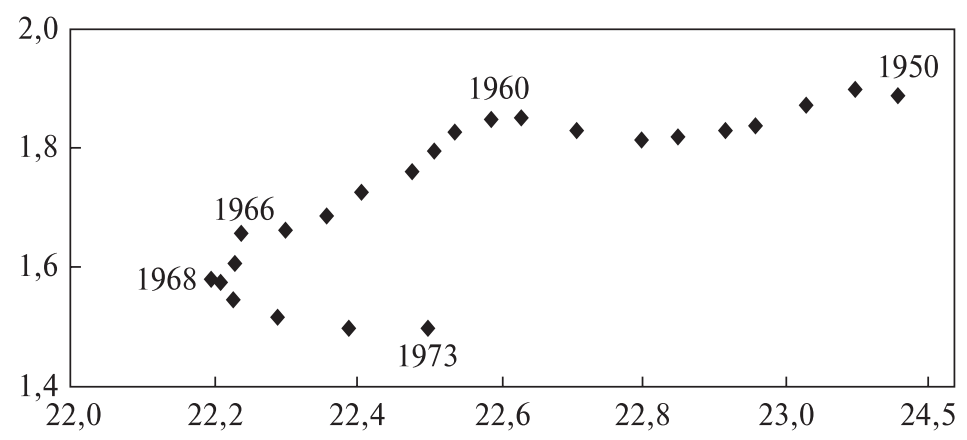

Рис. 9. Вичерпаний коефіцієнт плідності (на момент досягнення когортою 40 років) залежно від середнього віку матері при народженні первістка в Україні Джерело: за даними Human Fertility Database.

Висновки. Підвищення середнього віку матері при народженні першої дитини було зумовлено не стільки зменшенням інтенсивності народжуваності у наймолодших репродуктивних групах жінок, скільки посиленням дітородної активності у жінок віком старше 25 років. За допомогою графічного методу виокремлено і досліджено чотири етапи (фази) у змінах зв'язку віку материнства та рівня народжуваності, що спостерігаються в європейських країнах, статистичні матеріали яких дають змогу прослідкувати динаміку названих показників у відносно тривалий проміжок часу для умовних поколінь. На першому етапі омолодження материнства переважно поєднується з коливаннями сумарного показника народжуваності; на другому етапі середній вік матері при народженні дитини стабілізується, а от інтенсивність народжуваності стрімко падає; на третьому відбувається перехід до постаріння материнства, що зазвичай супроводжується зниженням рівня народжуваності; на четвертому подальше підвищення середнього віку матері при народженні дитини розгортається за підвищення сумарного показника народжуваності або його відносної стабілізації. Графіки зв'язку рівня народжуваності та середнього віку матері при народженні дитини, побудовані для нашої країни та інших європейських країн, мають схожі конфігурації, що може свідчити про еволюційний характер розвитку народжуваності в Україні. Різний початок трансформації та різний перебіг змін складових дітородної поведінки (зокрема, обмеження числа дітей у сім'ї, відкладання народження дитини на старший вік, обов'язковість перебування у шлюбі для задоволення потреби мати дитину тощо) зумовили різні відхилення від основної траєкторії перебудови зв'язку віку материнства і рівня народжуваності. Зважаючи на вагомість впливу соціально-економічних чинників на дітородну поведінку, доцільно з'ясувати, які фактори і в якому напрямі спричиняють найбільші відхилення, що може стати темою для подальшого демографічного дослідження. У ході дослідження було підтверджено, що зниження рівня народжуваності не обов'язково пов'язано з відкладанням дітонародження. Зміна середнього віку матері при народженні дитини може відбуватися у періоди відносної стабілізації інтенсивності народжуваності, й навпаки, рівень народжуваності в умовних поколіннях може змінюватися за відносно стійкого показника віку материнства. 


\section{ЛІТЕРАТУРА}

1. Эдиев Д.М. О роли среднего возраста матери при рождении ребенка о долгосрочной демографической динамике // Вопросы статистики. - 2006. - Вып. 11. - С. 23-31.

2. Сифман Р.И. Динамика рождаемости в СССР. - М.: Статистика, 1974. -183 с.

3. Щербакова E. Средний возраст матери при рождении ребенка вырос во всех странах ЕС-27 [Електронний ресурс]. - Режим доступу: http://www.demoscope.ru/weekly/2011/0461/ barom03. php (дата звернення: 04.03.2019).

4. Шевчук П.Є. Удосконалення підходів до оцінки рівня народжуваності для умовного покоління // Статистика України. - 2008. - № 2 (41). - С. 82-86.

5. Frejka T. The Role of Contemporary Childbearing Postponement and Recuperation in Shaping Period Fertility Trends // Comparative Population Studies - Zeitschrift für Bevölkerungswissenschaft. 2011. - Vol. 36, 4. - P. 927-958. - https://doi.org/10.4232/10.CPoS-2011-20en

6. Frejka T., Sardon J.-P. First birth trends in developed countries: a cohort analysis, № WP-2006-014, MPIDR Working Papers / Max Planck Institute for Demographic Research. - Rostock, Germany, 2006 [Електронний ресурс]. - Режим доступу: https://www.demographic-research.org/volumes/.../ 15-6.pdf (дата звернення: 07.02.2019).

7. The Human Fertility Database: A joint project of the Max Planck Institute for Demographic Research and the Vienna Institute of Demography (VID) [Електронний ресурс]. - Режим доступу: https:// www.humanfertility.org/cgi-bin/main.php (дата звернення: 12.02.2018).

8. Kohler H-P., Billari F.C., Ortega J.A. The Emergence of Lowest-Low Fertility in Europe During the 1990s // Population and Development Review. - 2002. - Vol. 28, Iss. 4.- P. 641-680. - https://doi. org/10.1111/j.1728-4457.2002.00641/x

9. Демографическая модернизация России, 1900-2000 / Под ред. А.Г. Вишневского. - М.: Новое издательство, 2006. - 608 с.

10. Аксьонова С.Ю. Черговість народження у матерів середнього і пізнього репродуктивного віку // Демографія та соціальна економіка. - 2015. - № 3 (25). - С. 64-74. - https://doi.org/10. $15407 /$ dse2015.03.004

11. Leridon $H$. Can assisted reproduction technology compensate for the natural decline in fertility with age? A model assessment // Human Reproduction. - 2004. - Vol. 19. Iss. 7. - P. 1548-1553. - https://doi. org/10.1093/humrep/deh304

\section{REFERENCES}

1. Ediyev, D.M. (2006). O roli srednego vozrasta materi pri rozhdenii rebenka v dolgosrochnoy demograficheskoy dinamike [On the role of the average age of the mother at the birth of a child about the long-term demographic dynamics]. Voprosy statistiki - Statistical issues, 11, 23-31 [in Russian].

2. Sifman, R.I. (1974). Dinamika rozhdayemosti v SSSR [Dynamics of fertility in the USSR]. Moskow: Statistika [in Russian].

3. Shcherbakova, Y. (2011). Sredniy vozrast materi pri rozhdenii rebenka vyros vovsekh stranakh EU [The average age of the mother at birth was increased in all EU-27 countries]. Demoscope - Demoscope. Retrieved from: http://www.demoscope.ru/weekly/2011/0461/barom03.php [in Russian].

4. Shevchuk, P.Y. (2008). Udoskonalennya pidkhodiv do otsinky rivnya narodzhuvanosti dlya umovnoho pokolinnya [Improvement of Approaches to Assessing the Birth Rate for Conditional Generation]. Statystyka Ukrayiny - Ukrainian Statistics, 2 (41), 82-86 [in Ukrainian].

5. Frejka T., (2011) The Role of Contemporary Childbearing Postponement and Recuperation in Shaping Period Fertility Trends. Comparative Population Studies - Zeitschrift für Bevölkerungswissenschaft, 36, 4, 927-958. - https://doi.org/10.4232/10.CPoS-2011-20en

6. Frejka, T., \& Sardon, J.-P. (2006). First birth trends in developed countries: a cohort analysis. Demographic research, 15, 147-180. Retrieved from https://www.demographic-research.org/volumes/.../15-6.pdf

7. The Human Fertility Database (2017). A joint project of the Max Planck Institute for Demographic Research and the Vienna Institute of Demography (VID). humanfertility.org. Retrieved from https://www. humanfertility.org/cgi-bin/main.php 
8. Kohler, H-P., Billari, F.C., \& Ortega, J.A. (2002). The Emergence of Lowest-Low Fertility in Europe During the 1990s. Population and Development Review, 28 (4), 641-680. - https://doi.org/10.1111/ j.1728-4457.2002.00641/x

9. Vishnevsky, A.G. (Eds.). (2006). Demograficheskaya modernizatsiya Rossii, 1900-2000 [Demographic modernization of Russia, 1900-2000]. Moskow: Novoye izdatel'stvo [in Russian].

10. Aksonova, S.Y. (2015). Cherhovist narodzhennya u materiv serednoho i piznoho reproduktyvnoho viku [Parity Distribution Trends of Women in the Middle and Late Reproductive Age Groups]. Demohrafiia ta sotsial'na ekonomika - Demography and social economy, 3 (25), 64-74. - https://doi.org/ 10.15407/ dse2015.03.004 [in Ukrainian].

11. Leridon, H. (2004). Can assisted reproduction technology compensate for the natural decline in fertility with age? A model assessment. Human Reproduction, 19, 1548-1553. - https://doi.org/10.1093/ humrep/deh304

Стаття надійшла до редакції журналу 17.04.2019. 


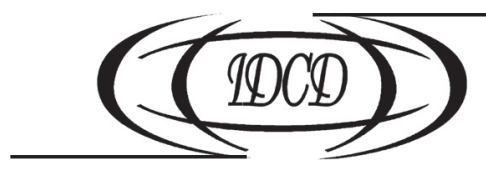

https://doi.org/10.15407/dse2019.02.039

УДК 314.37

JEL CLASSIFICATION: J13 J18

\title{
Б.O. KPIMEP
}

канд. екон. наук, старш. наук. співроб.

Інститут демографії та соціальних

досліджень ім. М.В. Птухи НАН України

01032, Україна, м. Київ, бул. Т. Шевченка, 60

E-mail: b.krimer.demostudy@gmail.com

ORCID 0000-0002-2103-6622

\section{ПОЛІТИКА СПРИЯННЯ ОДИНОКИМ БАТЬКАМ: СУЧАСНИЙ СТАН ТА ПЕРСПЕКТИВИ РОЗВИТКУ}

\begin{abstract}
Розглянуто політику сприяння одиноким батькам як складову сімейної політики - передумови виникнення, інструментарій, проблемні аспекти та перспективи подальшого розвитку. Потирення одинокого батьківства висвітлено як закономірний наслідок соціально-економічних та демографічних трансформацій. Однобатьківська сім'я часто є свідомим вибором людини і має достатній потенціал для повноцінного розвитку дитини. Проте в результаті поширення одинокого батьківства виникає ряд проблем, зокрема щодо бідності сімей з дітьми та можливостей поєднання батьківства й зайнятості. Подібність демографічного розвитку України та інших розвинутих країн обумовила схожість супутніх соціально-економічних викликів, а також можливість використання позитивного досвіду вирішення проблем, зокрема у сфері сприяння одиноким батькам. Сучасна політика такого сприяння $\epsilon$ комплексом заходів зі створення комфортного соціально-економічного середовища для одиноких батьків з дітьми. Найефективнішою у боротьбі з бідністю одиноких батьків є комплексна стратегія, яка поєднує надання матеріальної підтримки одиноким батькам, сприяння зайнятості батьків та надання соціальних послуг з догляду за дитиною, поширення гендерної рівності. Перехід від пріоритетності матеріальної підтримки одиноких батьків з дітьми до розширення можливостей щодо зайнятості $\epsilon$ тривалою тенденцією в сімейній політиці розвинутих країн - сприяння зайнятості є основним способом зменшення ризиків бідності однобатьківських сімей. Водночас, поширення неповної зайнятості підвищує рівень бідності одиноких батьків, тому особливої ваги для розширення їхніх можливостей щодо зайнятості та забезпечення достатку набуває доступність послуг із догляду за дитиною. Серед напрямів розвитку політики сприяння одиноким батькам в Україні можна назвати удосконалення системи диференційованої матеріальної підтримки за черговістю народжених дітей; розширення мережі дошкільних закладів, поліпшення якості їхньої роботи, підвищення рівня підготовки персоналу дошкільних закладів, поширення інших форм догляду за дитиною в ранньому віці (доглядальники, сімейні дитячі садки), підвищення гнучкості системи зайнятості для одиноких батьків, збільшення можливостей навчання, перекваліфікації та пошуку роботи.
\end{abstract}

Ключові слова: сімейна політика, одинокі батьки, соціальна політика, зайнятість, бідність, дошкільні заклади.

(C) KPIMEP Б.O., 2019

ISSN 2072-9480. Демографія та соціальна економіка, 2019, № 2 (36): 39-51 


\section{Б.А. Кример}

канд. экон. наук, старш. науч. сотруд.

Институт демографии и социальных

исследований им. М.В. Птухи НАН Украины

01032, Украина, г. Киев, бул. Т. Шевченко, 60

E-mail: b.krimer.demostudy@gmail.com

ORCID 0000-0002-2103-6622

\section{ПОЛИТИКА СОДЕЙСТВИЯ ОДИНОКИМ РОДИТЕЛЯМ: СОВРЕМЕННОЕ СОСТОЯНИЕ И ПЕРСПЕКТИВЫ РАЗВИТИЯ}

Рассмотрена политика содействия одиноким родителям как составляющая семейной политики - предпосылки возникновения, инструментарий, проблемные аспекты и перспективы дальнейшего развития. Распространение одинокого родительства рассмотрено как закономерное следствие социально-экономических и демографических трансформаций, однородительская семья часто оказывается сознательным выбором человека и обладает достаточным потенциалом для полноценного развития ребенка. В результате распространения одинокого родительства возникает ряд проблем, в частности относительно бедности семей с детьми и возможностей сочетания родительства и занятости. Сходство демографического развития Украины и других развитых стран обусловило и подобие сопутствующих социально-экономических вызовов, а также возможность использования положительного опыта для решения проблем, в частности в сфере содействия одиноким родителям. Современная политика содействия им - комплекс мероприятий по созданию комфортной социально-экономической среды. Наиболее эффективной в борьбе с бедностью одиноких родителей считается комплексная стратегия, оббединяющая материальную поддержку одиноких родителей, содействие их занятости и предоставление социальных услуг по уходу за ребенком, обеспечение условий гендерного равенства. Переход от приоритетности материальной поддержки одиноких родителей с детьми к расширению возможностей их занятости служит длительной тенденцией в семейной политике развитых стран: содействие занятости одиноких родителей наилучшим способом упреждает их бедность. В тоже время, распространение неполной занятости повышает уровень бедности одиноких родителей, потому особенно важна для расширения возможностей занятости и обеспечения их благосостояния доступность услуг по уходу за ребенком. Среди направлений развития политики содействия одиноким родителям в Украине можно назвать совершенствование системы дифференцирования материальной поддержки относительно очередности рожденных детей; расширения сети дошкольных учреждений, улучшение качества их работы, повышение уровня подготовки персонала и удобства учреждений для родителей, распространение других форм ухода за ребенком в раннем возрасте (присмотр, семейные детские сады), расширение возможностей занятости одиноких родителей путем создания условий для гибкой занятости и обучения родителей, переквалификации и поиска работы.

Ключевые слова: семейная политика, одинокие родители, социальная политика, занятость, бедность, дошкольные учреждения.

\section{B.O. Krimer}

Ph. D (Economics), Senior Researcher

Ptoukha Institute for Demography and Social Studies

of the National Academy of Sciences of Ukraine

01032, Ukraine, Kyiv, Taras Shevchenko Blvd., 60

E-mail: b.krimer.demostudy@gmail.com

ORCID 0000-0002-2103-6622

\section{LONE PARENTS POLICY: MODERN DEVELOPMENT}

The paper is aimed at studying single-parents policy (as a component of family policy) development. The background of single-parents policy development, the current measures, the problems and prospects for further modernization in Ukraine are investigated. The increase in single parenthood as a regular consequence of socioeconomic and demographic transformations is considered: a single-parents family is often a conscious choice of a person and has adequate potential for the necessary development of a child. As a result of the spread of single parenthood, a number of problems arise. In particular, regarding the poverty of families with children and the 
difficulty of combining parenting and employment. The similarity of the demographic development of Ukraine and other developed countries led to the similarity of related socio-economic challenges, and also made it possible to use positive experience in solving the problems caused, in particular in the field of helping single parents. The modern policy of supporting single parents is a set of measures to create a comfortable social and economic environment for single parents with children. The most effective in combating poverty of single parents is considered to be a comprehensive assistance strategy that combines material support for single parents, promoting parental employment and the provision of social childcare services, and promoting gender equality. The transition from prioritizing material support to single parents with children to expanding employment opportunities is a longterm trend in the family policies of developed countries. Facilitating the employment of single parents as best as possible prevents their poverty, but the spread of underemployment increases the level of poverty of single parents. Especially important for expanding employment opportunities and ensuring the welfare of single parents is the availability of childcare services. Among the ways to improve the policy of helping single parents in Ukraine are: improving the material support system regarding differentiation in order of priority, expanding the network of available preschool institutions, improving the quality of preschool institutions, staff training and facilities for parents, distributing other forms of child care at an early age (caring, family kindergartens), empowering single parents regarding employment by increasing the flexibility of employment and creating training opportunities for parents, retraining and job search.

Keywords: lone parents, social policy, employment, poverty, pre-school establishments.

Актуальність. Сучасні демографічні зрушення, трансформації шлюбу та сім’ї, плюралізація форм батьківства формують нові виклики для сімейної політики розвинутих країн. Перебіг демографічних процесів і плюралізація в сфері шлюбно-сімейних відносин в останні десятиліття вказують, що практика утримання та виховання дітей одинокими батьками поширюватиметься і в Україні, відповідно все більшої актуальності набуватимуть пов'язані з цим ризики. Демографічна модернізація суспільства в Україні відбувається в руслі загальносвітових демографічних тенденції, зокрема характерного для розвинутих країн Європи «Другого демографічного переходу», однією з рис якого є зростання частки позашлюбних народжень.

Постановка проблеми. Сімейна політика, метою якої є створення найкомфортнішого для народження й виховання дітей соціально-економічного середовища та «Пом'якшення» основних ризиків батьків з дітьми, еволюціонує відповідно до демографічних трансформацій, а підтримка одиноких батьків стає важливим завданням у різних країнах. Вивчення провідного зарубіжного досвіду дає підстави розглянути можливості впливу на пов'язані з одиноким батьківством проблеми і сформулювати рекомендації для вдосконалення сімейної політики України.

Аналіз останніх досліджень і публікацій. Сімейна політика розвинутих країн, функціонування іiі інструментів і вплив на соціально-економічний та демографічний розвиток уже тривалий час перебувають у полі зору сучасних науковців. Ці питання розглядали Г. Неєр (G. Neyer), П. Макдоналд (P. McDonald), T. Соботка (T. Sobotka), О. Тевенон (O. Thevenon) та ін. Зростання вагомості проблем одиноких батьків для сучасної соціальної політики висвітлено в роботах К. Еспін-Андерсен (С. EspingAndersen), Д. Боноллі (G. Bonolli). Функціонування інструментів сімейної політики, орієнтованих на одиноких батьків, досліджували Р. Ньевенхуіс (R. Nieuwenhuis) та Л. Малдонадо (L. Maldonado), пояснивши, зокрема, високий рівень бідності одиноких батьків з дітьми на тлі високого рівня зайнятості. Подібне пояснення на прикладі Нідерландів надали С. Дуюлмус (С. Duyulmus) та А. Ван де Берг (A. Van den Berg). Дослідження одинокого материнства в Росії виконав C. Захаров (S. Zaharov).

Соціально-економічне становище одиноких батьків з дітьми у розвинутих країнах і проблеми орієнтованої на них соціальної політики вивчено під час тривалих 
науково-дослідних проектів міжнародних організацій, наприклад, проекту Doing Better for Families (OECD, 2011) та Families and Societies (EU, 2017).

Досліджують сучасні трансформації у сфері шлюбно-сімейних відносин, та, зокрема, інституту батьківства, а також передумови та характер поширення однобатьківських сімей в Україні Л. Слюсар (L. Slyusar) та I. Курило (I. Kurilo). Вивченням бідності сімей із дітьми та неповних сімей займались А. Реут (A. Reut) і Л. Черенько (L. Cherenko). Юридичний бік соціального захисту сімей з дітьми за законодавством України, зокрема й щодо одиноких батьків, досліджувала К. Бориченко (К. Borychenko).

Мета цієї роботи - розвинути уявлення про політику сприяння одиноким батькам, дослідити сучасний стан політики сприяння одиноким батькам в Україні та країнах Європи, сформулювати рекомендації щодо розвитку політики сприяння одиноким батькам в Україні.

Новизна полягає у доповненні уявлень щодо підтримки одиноких батьків у сучасній системі сімейної політики і у формуванні рекомендацій щодо удосконалення сімейної політики України.

Методи дослідження. 3 методів наукового дослідження застосовані порівняння, аналіз, узагальнення та індукція. Для передбачення потенційних змін у демографічних процесах та аналізу впливу спрямованої на однобатьківські сім’ї соціальної політики використано метод історичної аналогії та системний підхід, для формування висновків - абстрактно-логічний метод.

Інформаційна база. Робота базується на масиві статистичних індикаторів, що характеризують поширення та соціально-економічне становище однобатьківських сімей. Масив сформований за матеріалами Державної служби статистики України, Організації економічного співробітництва та розвитку (OECD Family Database), Євростату (Eurostat), а також аналітичних матеріалів щодо сімейної політики, зокрема опублікованих в рамках проектів Doing Better for Families та Families and Societies.

Виклад основного матеріалу. Поширення однобатьківських сімей, в яких виховання та догляд за дитиною здійснює один із батьків, а не сімейна пара, є наслідком тривалого процесу трансформації інститутів шлюбу та сім’ї під впливом загального соціально-економічного розвитку та демографічної модернізації. Характерні для сучасного суспільства свобода вибору та емансипація безпосередньо впливають на шлюбно-сімейну поведінку населення, результатом чого є плюралізація форм батьківства. На противагу минулим історичним етапам, коли причиною одинокого батьківства часто був негативний вплив зовнішніх обставин (зокрема, смерть одного з батьків), формування сучасної однобатьківської сім’ї $є$ найчастіше результатом розв’язання кризової ситуації: невдалий шлюб, криза у подружніх стосунках, неможливість знайти шлюбного партнера [1]. Усе частіше одиноке батьківство є свідомим вибором. Саме тому однобатьківські сім'ї треба сприймати як закономірне явище в межах сучасного демографічного розвитку, поширеність якого має перспективи щодо зростання.

Сучасні дослідження наголошують, що однобатьківські сім’ї мають достатній потенціал для повноцінного виховання і розвитку дитини [2], проте існує й ряд важливих проблем, зокрема, економічних. Одиноке батьківство визначають нині як «новий соціальний ризик» [3]. Найочевиднішою проблемою є більший ризик бідності однобатьківських сімей ніж сімейних пар з дітьми. На тлі економічних негараздів існує і ризик депресії та асоціальної поведінки дітей в однобатьківських сім’ях; відсутня традиція участі батька, який не проживає з дитиною, уії вихованні [1]. 
Надзвичайно гострою для однобатьківських сімей є проблема поєднання зайнятості та сімейного життя.

Трансформація шлюбу та сім’ї в України відбувається у руслі загальноєвропейських і світових тенденцій демографічного та соціального розвитку, помітною рисою сучасного етапу є поширення позашлюбної народжуваності. В Україні частка позашлюбних народжень в останні роки дещо перевищує 20 \% й є близькою до визначеної у Польщі (25\%), Хорватії (19\%), Молдові (22 \%). У деяких країнах Європи ця частка вже перевищила 50 \% усіх народжень (Франція, Норвегія, Швеція, Естонія, Словенія). Для країн Евросоюзу (ЕС-28) значення частки позашлюбних народжень виросло 3 27 \% у 2000 до 43 \% у 2016 році. Відносно низька частка позашлюбних народжень в Україні є історично обумовленою й пов'язаною з тим, шо більшість населення вважає саме офіційне шлюбне партнерство найкращим варіантом для народження дитини [4]. Проте тривала динаміка цього показника (у 1990-му частка позашлюбних народжень становила $10 \%$ ) та загальноєвропейська тенденція зростання свідчать про можливість подальшого збільшення частки позашлюбних народжень в Україні.

Іншим напрямом утворення однобатьківських сімей є розірвання шлюбу, в результаті чого дитина залишається з одним із батьків. В сукупності розвинутих країн, що входять до Організації економічного співробітництва та розвитку (ОЕСР), шлюбні пари з дітьми більш схильні до розлучень, ніж шлюбні партнери без дітей. Загалом у сукупності цих країн понад половина сімей, що розлучаються, мають принаймні одну дитину, а в Польщі, Угорщині, Фінляндії та Португалії ця частка більша за $60 \%$. Наявність дітей у парах, що розлучаються, обумовлена тривалістю шлюбу, яка найчастіше становить понад 20 років (27 \% усіх розлучень), $23 \%$ розлучень відбувається після 5-9 років шлюбу (27 \% в Естонії та Великій Британіі). Зовсім незначна кількість шлюбів - менше $1 \%$ розпадається упродовж року [5].

Домогосподарства із одинокими батьками й дітьми в усіх розвинутих країнах становлять меншість - 7,7\% у країнах OECP та 6,8 \% у країнах ЄС. Проте їхня частка є істотно різною у різних країнах. Так, у Латвії частка домогосподарств із одинокими батьками складає $11 \%$ від усіх домогосподарств, у Японії - 3 \%. Усюди абсолютна більшість однобатьківських домогосподарств - це домогосподарства, де діти проживають з матір'ю (5,6 \% усіх домогосподарств або ж 82 \% однобатьківських домогосподарств), а не з батьком (18\% однобатьківських домогосподарств) [5]. В Україні більшість сімей із дітьми залишається традиційними: у 80 \% сімей діти мешкають з обома батьками, майже 80 \% дітей народжується у батьків, які перебувають у зареєстрованому шлюбі. Водночас у кожному п'ятому домогосподарстві, де є діти, вони мешкають без одного чи обох батьків [6].

Одним із найгостріших викликів, що постають перед політикою сприяння одиноким батькам у розвинутих країнах, є високий рівень бідності однобатьківських сімей. Домогосподарства з дітьми, загалом, мають вищі ризики бідності, ніж бездітні домогосподарства, що спостерігається, зокрема, в 28 із 36 країн ОЕСР (винятками є Данія, Фінляндія, Естонія, Словенія, Латвія, Норвегія, Швеція та Корея), де межа бідності на рівні 50 \% медіанного доходу. 32004 до 2013 року рівень бідності сімей 3 дітьми зріс у 13 країнах ОЕСР й подекуди це зростання було досить помітним (4 \% у Іспанії, $6 \%$ у Греціі). Але спостерігалось і зниження цього показника: на 5 \% у Ірландії та 10 \% у Польщі.

Однобатьківські домогосподарства перебувають у складних умовах, ризики їхньої бідності особливо зростають під час економічних криз. Рівень бідності домогосподарств із дітьми та з однією дорослою людиною виглядає надзвичайно високим - 31,6 \% для усієї сукупності країн ОЕСР, в той час як у домогосподарствах 
3 дітьми, де є двоє дорослих, рівень бідності майже втричі менший - 10,2\%. Зокрема, в Іспанії рівень бідності однобатьківських домогосподарств складає 42,9 \%, а в домогосподарствах з дітьми, де є двоє дорослих - 19\%, у Франції - 24,7 та 6, в Швеції - 26,2 та 5, у Польщі - 30,5 та 11, в Естонії - 32,5 та 9,2 \% відповідно [5]. У ряді країн ОЕСР різниця може становити понад 30 \% (Канада, Австралія, Чехія), що характеризує однобатьківські домогосподарства як проблемні, навіть у достатньо заможній країні й за загального низького рівня бідності. Таким чином проблема високого рівня бідності однобатьківських домогосподарств є вкрай вагомою для усіх розвинутих країн.

Складність забезпечення добробуту в однобатьківській сім’ї, властива усім розвинутим країнам, добре помітна з порівняння доходів у різних типах домогосподарств. Домогосподарства $з$ дітьми й одним дорослим, як правило, мають помітно нижчі доходи, ніж бездітні домогосподарства 3 двома дорослими. Зокрема, в Польщі - на 18,4, Франції - 37,2, в Іспанії - на 15,7 \% (таблиця). Також доходи батьків-одинаків нижчі, ніж в інших домогосподарствах із дітьми (де є двоє дорослих, один з яких працює) - в Польщі - на 11,6, Франції - 9,5, в Іспанії - на 21,3 \%. Загалом у країнах ОЕСР домогосподарства батьків-одинаків мають середній дохід на рівні 70 \% від доходу домогосподарств із двох дорослих, один із яких працює. Водночас, зайнятість батьків сприяє забезпеченню достатку сімей з дітьми - домогосподарства 3 двома та більше працюючими дорослими мають дохід майже того ж рівня, що й домогосподарства без дітей та з одним дорослим, а в деяких країнах і значно вищий дохід. Різниця в доходах домогосподарств із двома працюючими батьками й домогосподарств батьків-одинаків, становить 28 \% у Франції, 46 - у Польщі, 58 - у Естонії.

Домогосподарства з дітьми й однією дорослою особою в Україні також характеризуються вищим рівнем матеріальних проблем, ніж інші домогосподарства $з$ дітьми. Незважаючи на те, що монетарна бідність однобатьківських сімей менш виражена, ніж сімей із дітьми загалом, інші аспекти бідності є досить чіткими. Зокрема, в однобатьківських сім’ях більш ніж утричі рідше є автомобіль, нижчою є забезпеченість

Таблиия. Співвідношення середніх доходів різних типів домогосподарств з дітьми порівняно з домогосподарством із двох дорослих без дітей у країнах Европи, \%

\begin{tabular}{|c|c|c|c|c|}
\hline \multirow[t]{2}{*}{ Країна } & \multirow{2}{*}{$\begin{array}{c}\text { Двоє чи більше } \\
\text { дорослих праце- } \\
\text { здатного віку, один } \\
\text { з яких працює, без } \\
\text { дітей } \\
\end{array}$} & \multirow{2}{*}{$\begin{array}{c}\text { Один дорослий } \\
\text { працює, одна } \\
\text { дитина }\end{array}$} & \multicolumn{2}{|c|}{$\begin{array}{c}\text { Двоє чи більше дорослих працездатного } \\
\text { віку }\end{array}$} \\
\hline & & & $\begin{array}{l}\text { принаймні одна дити- } \\
\text { на, один з них працює }\end{array}$ & $\begin{array}{l}\text { два чи більше з } \\
\text { них працюють }\end{array}$ \\
\hline Естонія & 100 & 89,3 & 109,9 & 147,7 \\
\hline Іспанія & 100 & 84,3 & 63,0 & 113,4 \\
\hline Польща & 100 & 81,6 & 73,2 & 119,5 \\
\hline Чехія & 100 & 68,7 & 90,6 & 115,6 \\
\hline Німеччина & 100 & 68,6 & 85,7 & 102,3 \\
\hline Італія & 100 & 67,8 & 63,4 & 115,4 \\
\hline Швеція & 100 & 63,6 & 73,6 & 105,1 \\
\hline Франція & 100 & 62,8 & 72,3 & 99,4 \\
\hline
\end{tabular}

Джерело: складено на основі OECD Family Database. 
абсолютно усіма товарами тривалого користування. За даними вибіркового обстеження домогосподарств щодо самооцінки власних доходів, серед однобатьківських домогосподарств 55 \% зазначали, що постійно відмовляли собі в найнеобхіднішому, серед усіх домогосподарств 3 дітьми цей показник менший за 40,1\%. Також серед однобатьківських домогосподарств 82 \% відносять себе до бідних, а серед усіх домогосподарств з дітьми таких 70,6 \% . Цікаво, що 50 \% однобатьківських домогосподарств зазначили, що додаткові доходи спрямували б на освіту, а серед усіх домогосподарств із дітьми це зробили б лише 30,1 \% [7]. Загалом, сім'ї з неповнолітніми дітьми становлять найуразливішу з точки зору малозабезпеченості групу населення в Україні, де ризик бідності традиційно зростає зі збільшенням кількості дітей в родині. Так, за межею відносної бідності 75 \% медіанних сукупних еквівалентних витрат у 2015 р. перебувала кожна третя дитина, а найменший ризик потрапити до категорії бідних в Україні мають ті домогосподарства з дітьми, в яких всі дорослі особи працюють (у 2015 р. рівень відносної бідності - 18,9\%) [8].

Сприяння батькам із дітьми, запобігання бідності, створення для них якомога комфортнішого соціально-економічного середовища та «пом'якшення» основних ризиків знаходиться в полі зору сімейної політики, яка еволюціонує під впливом зовнішніх викликів, серед яких, безумовно, поширення однобатьківських сімей. Із 35 країн ОЕСР на даний час тільки чотири не використовують жодних спеціалізованих інструментів підтримки одиноких батьків. Сприяння одиноким батькам, зокрема щодо запобігання їхній бідності здійснюється шляхом комплексного поєднання «традиційних» інструментів сімейної політики - матеріальної підтримки сімей з дітьми, засобів сприяння зайнятості батьків, соціальних послуг із догляду за дитиною тощо.

Матеріальна допомога одиноким батькам з дітьми є інструментом, що зменшує ризики бідності цієї категорії населення. Сучасні дослідження визнають ефективність матеріальної підтримки у боротьбі з бідністю батьків із дітьми, особливо коли існують спеціалізовані інструменти, орієнтовані на одиноких батьків (грошові виплати, компенсація витрат на житло чи використання соціальних послуг з догляду за дитиною, а також забезпечення виплати аліментів), проте наголошують, що рівень соціальної допомоги майже в усіх розвинутих країнах є недостатнім для досягнення загальноприйнятих порогів бідності [9]. Матеріальна допомога одиноким батькам існує, як правило, у вигляді щомісячних платежів, не значних за обсягом, проте диференційованих за черговістю дитини та досить часто пролонгованих на великий інтервал часу - до досягнення дитиною віку 18-22 років.

Зокрема, в розгалуженій системі підтримки батьків із дітьми у Франції матеріальна допомога для одиноких батьків помітно більша, ніж для інших батьків, надається на умовах адресності (з урахуванням рівня доходу), а також диференційована за черговістю - розмір зростає з кожною наступною дитиною. Також є цільова невелика допомога для вирішення житлових проблем одиноких батьків [10].

Важливо, що найкращі результати матеріальної підтримки для зниження бідності однобатьківських сімей спостерігаються в тих країнах, де поєднано універсальні виплати й пільги сім'ям з дітьми з додатковими пільгами саме для одиноких батьків [11].

Проте, щедра матеріальна підтримка батьків із дітьми може мати й несподівані негативні наслідки: в ряді досліджень доведено, що значна матеріальна підтримка одиноких батьків, які перебувають у відпустках по догляду, може мати наслідком нижчий рівень зайнятості або менш сприятливі умови зайнятості, що, в результаті, призведе до вищого рівня бідності [2]. 
Важливою рисою сучасної політики підтримки одиноких батьків, що впливає на усі застосовувані інструменти, є їі орієнтованість на обох батьків, а не виключно на матір. Заохочення практичної гендерної рівності є загальним вектором розвитку сімейної політики країн Європи, що має вплив на зменшення материнської та дитячої бідності, залучення батьків до догляду за дитиною, вищі показники народжуваності. Можна сказати, що взаємозв'язок зайнятості, гендерної рівності та дитячої бідності все більше обумовлює спрямування сімейної політики розвинутих країн.

На перший погляд, «конфігурація» системи матеріальної підтримки сімей з дітьми в Україні, відповідає наведеним вище рекомендаціям і охоплює універсальну одноразову допомогу при народженні дитини та спеціалізовану допомогу одиноким матерям. Проте тривалість виплат є досить незначною, а також відсутня диференціація за черговістю. Щомісячна допомога одиноким матерям характерна ще й тим, що можливості отримання допомоги одиноким батьком суттєво обмежені (надається удівцям та усиновителям). Цю допомогу все частіше, зокрема у професійному середовищі, коректніше називають «допомогою на дітей одиноким особам», хоча у відповідному законі назва все ще сформульована як «допомога одиноким матерям».

Сама конструкція Закону України «Про державну допомогу сім’ям з дітьми» дає можливість говорити про їі обмежувальний характер, оскільки закріплено право на допомогу на дітей лише за одинокими матерями. Також законодавство України не містить чіткого визначення понять «одинока мати» чи «одинокий батько», замінюючи їх лише перерахуванням характеристик, яким вони повинні відповідати задля отримання цієї допомоги [12].

Розмір допомоги на дітей одиноким особам в Україні не можна вважати вагомим, проте спостерігається зростання обсягів виплат упродовж останніх років - в 2015 році середній розмір допомоги на дітей одиноким особам становив 367 грн, й отримували iii 188,5 тис. одержувачів на 725,2 тисячі дітей. 2016 року середній розмір цієї допомоги виріс до 855 грн, а у 2017 - до 1038 грн й отримували цю допомогу на 463,5 тисячі дітей. Зауважимо: щомісячні виплати одиноким батькам у країнах Європи теж за звичай не є вагомими, проте часто тривають до переходу дитини в дорослий вік.

На достаток однобатьківських сімей впливає матеріальна підтримка з боку другого з батьків, яка надається шляхом виплати аліментів. Законодавство України, аналогічно до інших країн Европи, передбачає обов'язок батьків утримувати дитину до досягнення нею повноліття. Важливість цього аспекту в сучасних умовах підтверджується даними Міністерства юстиції України про те, що на початок 2018 року в органах державної виконавчої служби України перебувало на виконанні 531,7 тисяч документів щодо стягнення аліментів. Тривалою проблемою були труднощі у стягненні аліментів, проте законодавчі нововведення 2017 року суттєво сприяють створенню відповідного ефективного механізму.

Політика боротьби з бідністю однобатьківських сімей також реалізується шляхом сприяння зайнятості батьків й саме цей напрям розглядається як найбільш важливий у забезпеченні достатку батьків і дітей. У розвинутих країнах зайнятість батьків розглядається як «запобіжник» від бідності батьків і дітей, тому значні зусилля докладаються для повернення батьків на ринок праці, набуття ними нових навичок і кваліфікацій, створення можливостей для пошуку необхідного робочого місця. У цьому контексті особливої актуальності набувають заходи щодо поєднання зайнятості й сімейного життя. Зокрема, гнучкість відпусток по догляду за дитиною, можливості часткової зайнятості, надання соціальних послуг з догляду за дитиною. 
Відпустки по догляду за дитиною, запроваджені задля підтримки одиноких батьків, повинні мати достатню тривалість задля забезпечення належної участі в догляді та вихованні дитини. Однак існують ризики, що надмірно довга відпустка батьків має шкідливий вплив на економічні перспективи одиноких батьків. Важливий також рівень оплачуваності відпустки, оскільки неоплачувані або низькооплачувані відпустки не заохочують працівників ними користуватись.

В Україні законодавство передбачає оплачувану відпустку у зв’язку з вагітністю та пологами і тривалу, але неоплачувану відпустку по догляду за дитиною до досягнення нею трирічного віку, яку окрім матері також може взяти батько або інший родич. Порівняно з Україною, відпустки по догляду за дитиною в Свропі є достатньо тривалими й частково оплачуваними (від 31 \% у Великій Британії до 100 \% в Іспаніi), у більшості розвинених країн батьківські відпустки оплачуються на рівні понад 50 \% від попереднього заробітку. Специфічною проблемою України є дотримання роботодавцями трудового законодавства, оскільки поширення «тіньової» зайнятості позбавляє працівників передбачених законодавством пільг.

Усе поширенішими у розвинутих країнах стають відпустки, зарезервовані для батька, метою яких є якомога повніше залучення чоловіків до догляду за дитиною. Стверджується, що чоловіки, які активніше беруть батьківські відпустки, згодом охочіше беруть на себе частину хатніх справ, тим самим звільняючи жінку від «подвійного навантаження» [2]. Проте, у випадку одинокого батьківства, виникає ряд закономірних проблем щодо такого розподілу обов'язків.

Політика залучення батьків до ринку праці в розвинутих країнах дала результати - нині спостерігається поступове зростання економічної активності одиноких батьків. В країнах ОЕСР близько 75 \% одиноких батьків мають оплачувану роботу, а в Італії, Швеції та Португалії ця частка доходить до 85 \%. Ще у середині 1980-х зайнятими в цих країнах були 66 \% одиноких батьків. Не зважаючи на те, що саме зайнятість батьків розглядається як «запобіжник» від бідності й численні інструменти сімейної політики орієнтовані на спрощення участі батьків у ринку праці, висока зайнятість не гарантує відсутності ризиків бідності, чому підтвердженням може слугувати той факт, що за період з середини 1980-х до кінця 2000-х, на тлі зростання економічної активності одиноких батьків рівень їхньої бідності теж дещо зріс (з 30,0 \% до 31,2\%) [13].

Поєднання високої зайнятості та бідності можна вважати парадоксом, проте пояснення існує, якщо дивитись на ситуацію з урахуванням ряду факторів - гендерної рівності (зокрема освіти та можливості мати високодохідну зайнятість), доступу до зручних дошкільних закладів, специфіки сімейної політики. Дослідження становища одиноких батьків в Нідерландах продемонструвало, що активна політика щодо зайнятості одиноких батьків (з $25 \%$ зайнятих у середині 1980-х років до 76,2 \% у 2008 році), яка замінила політику «пасивної» матеріальної підтримки сімей з дітьми, сприяла зростанню їхньої бідності, оскільки більшість батьків працювали на умовах неповної зайнятості й на низько дохідних посадах [14]. Також одинокі батьки характеризувались як менш освічені та кваліфіковані, а тому мали працювати довше для забезпечення адекватного доходу.

В Україні традиційно зайнятість жінок без дітей значно перевищує зайнятість жінок із дітьми. Ризики бідності відповідно зростають у неповних сім'ях з дітьми. Про особливу вразливість самотніх жінок із дітьми свідчить той факт, що доходи від заробітної плати забезпечують лише 45 \% сукупних доходів цієї категорії населення (для порівняння: в структурі сукупних доходів жінок працездатного віку в 
цілому - 86,8 \%), а ризик бідності традиційно зростає зі збільшенням кількості дітей у родині [15].

На цьому тлі треба зважати на особливу роль системи соціальних послуг з догляду за дитиною в системі державної підтримки одиноких батьків. Доступні соціальні послуги з догляду за дитиною збільшують для батьків час продуктивної зайнятості, чим безпосередньо впливають на їхній добробут. Для одиноких батьків доступність дошкільних закладів має ще вагоміше значення, а відсутність їх стає величезною перешкодою на шляху зайнятості. Країни з розвинутою мережею доступних для батьків дошкільних закладів високого рівня характеризуються й високими показниками повної зайнятості батьків. Наприклад, у Франції та Швеції більшість (понад 60 \%) батьків-одинаків працюють саме на повний день [14]. Розвинута сфера дошкільних закладів зменшує рівень бідності одиноких батьків із дітьми у Фінляндії, Франції, Нідерландах, Норвегії, Великій Британії, Данії тощо. Серед проблем сфери дошкільних закладів у деяких країнах можна виділити високу вартість, що обмежує доступність, та недостатньо високий рівень послуг. Варто наголосити на важливості державної підтримки сфери дошкільних закладів і необхідності сприяння саме одиноким батькам у забезпеченні доступності догляду за дитиною.

Прикладом країни з розвинутою системи послуг по догляду за дитиною є Франція, де дошкільні заклади доступні з тримісячного віку, проте доступ до різних типів догляду за дитиною помітно залежить від рівня доходів батьків. В 2012 році тільки $63 \%$ дітей у віці до трьох років у Франції доглядали батьки, $6 \%$ - інші родичі, $13 \%$ користувались послугами дошкільних закладів, 18 \% - індивідуальних доглядальників. Зі зростанням доходу частка дітей, яких доглядають батьки, зменшується, а використання соціальних послуг з догляду за дитиною зростає. Серед батьків, які працюють на умовах повної зайнятості, послугами індивідуальних доглядальників користується вже $37 \%$. [16].

За останнє десятиліття помітно зріс рівень охоплення дошкільними закладами дітей у віці 0-2 роки і 3-5 років у країнах Європи, а також в Україні, хоча рівень охоплення у нас все ще є одним із найнижчих в Свропі (74,5 \% для дітей у віці 3-5 років і 14,1 \% для дітей 0-2 років). Проблемою України є помітна перевантаженість дошкільних закладів, яка є найгострішою в містах країни. Окрім браку місць варто згадати про відсутність гнучкої системи режиму дня в дошкільних установах, низьку якість надання послуг, нестачу сімейних дитячих садів (особливо в сільській місцевості); низький професіоналізм вихователів. Проте, саме сфера дошкільних закладів та інших форм догляду за дітьми є однією з перспектив розвитку сімейної політики України.

Якщо виходити з необхідності забезпечення достатку, то якомога повніше залучення батька до ринку праці є очевидним пріоритетом для політики підтримки батьків. Проте, з точки зору благополуччя дитини у віці до двох років важливою є і участь батька, що входить у конфлікт із необхідністю зайнятості та додатково обумовлює необхідність матеріальної підтримки батьків з дітьми [2].

Благополуччя дітей також пов'язане з сімейними стосунками, мікрокліматом, стосунками з батьками, конфліктами в оточенні. У цьому контексті існує необхідність в наданні інформаційно-консультативних послуг батькам, наявність програм примирення, розширення навичок батьків щодо вирішення кризових ситуацій, забезпечення належної участі обох батьків у вихованні дитини, подолання стресових ситуацій, інших психологічних та педагогічних проблем.

Висновки. Поширення однобатьківських сімей обумовлене соціально-економічними та демографічними трансформаціями останніх десятиліть й є характерною 
рисою сучасного демографічного розвитку в більшості розвинутих країн. Все частіше ситуація, коли один із батьків займається утриманням та вихованням дитини, $є$ наслідком саме свідомого вибору людини. Але, поширення однобатьківських сімей створює також і ряд проблем, зокрема щодо значно вищих ризиків бідності та ускладненого поєднання зайнятості та батьківства.

Сучасна політика підтримки одиноких батьків є комплексом заходів з надання матеріальної допомоги, забезпечення поєднання батьківства та зайнятості, надання соціальних послуг з догляду за дитиною. Однобатьківські сім’ї мають вищі ризики бідності, ніж бездітні сім’ї та сім’із обома батьками в більшості розвинутих країн світу й майже усюди рівень соціальної допомоги є недостатнім для досягнення загальноприйнятих порогів бідності.

Найкращі результати щодо зменшення бідності одиноких батьків спостерігаються в тих країнах, де поєднують зусилля для забезпечення повної зайнятості одиноких батьків і матеріальну підтримку - виплати універсального характеру й орієнтовані на одиноких батьків з дітьми. Гнучкість робочого графіку, можливості пошуку необхідної зайнятості та перекваліфікації сприяють убезпеченню батьків від бідності, проте поширення неповної зайнятості й тривале перебування у відпустках по догляду за дитиною збільшує рівень бідності одиноких батьків. Водночас соціальні послуги 3 догляду за дитиною збільшують для батьків доступний для продуктивної зайнятості час, чим безпосередньо впливають на їхній добробут. Важливою рисою сучасної політики сприяння одиноким батькам є їі орієнтованість на обох батьків і поширення гендерної рівності, пов'язаної з ринком праці, та, відповідно, з бідністю одиноких батьків.

Серед напрямів розвитку політики сприяння одиноким батькам в Україні можна назвати: удосконалення системи матеріальної підтримки щодо диференціації за черговістю народження дітей; розширення можливості зайнятості одиноких батьків шляхом збільшення гнучкості робочого графіку, можливостей навчання, перекваліфікації та пошуку роботи; нарощування мережі доступних дошкільних закладів, покращення якості їх роботи, підготовки персоналу та зручності для батьків, розвиток інших форм догляду за дитиною в ранньому віці (доглядальники, сімейні дитячі садки); поширення практичної гендерної рівності в суспільстві; надання інформаційно-консультативних послуг одиноким батькам та поліпшення їхніх навичок у різних сферах.

\section{ЛІТЕРАТУРА}

1. Слюсар Л.І. Специфіка батьківства у сім'ях різних типів: проблеми, ризики та шляхи їх мінімізації // Демографія та соціальна економіка. - 2017. - № 3 (31). - С. 24-36. - https://doi. org/10.15407/dse2017.03.024

2. Carlson L, Oláh L.S., Hobson B. Policy recommendations Changing families and sustainable societies: Policy contexts and diversity over the life course and across generations // FamiliesAndSocieties project consortium. - 2017 [Електронний ресурс]. - Режим доступу: http://www.familiesandsocieties. eu/wp-content/uploads/2017/06/WorkingPaper78.pdf (дата звернення: 03.02.2019).

3. Bonoli $G$. The Politics of the New Social Policies: Providing Coverage Against New Social Risks in Mature Welfare States // Policy \& Politics. - 2005. - Vol. 33. - P. 431-449.

4. Слюсар Л.І. Позашлюбна народжуваність в Україні: сучасні особливості в контексті європейського розвитку // Демографія та соціальна економіка. - 2018. - № 3 (34). - С. 26-38. - https://doi. org/10.15407/dse2018.03.026

5. Family size and household composition // OECD Family Database. - 2016 [Електронний pecypc] - Режим доступу: www.oecd.org/els/family/database.htm (дата звернення: 02.02.2019). 
6. Слюсар Л.І. Батьківство у системі відносин інституту сім'ї: сучасні трансформації, їх причини та наслідки // Демографія та соціальна економіка. - 2016. - № 2 (27). - С. 26-38. https://doi.org/10.15407/dse2016.02.026

7. Самооцінка домогосподарствами України рівня своїх доходів (за даними вибіркового опитування домогосподарств у січні 2017 року). Статистичний збірник / Держстат України. - Київ, 2017. - С. 21-28.

8. Реалізація конвенції ООН про права дитини в Україні: досягнення, проблеми, перспективи: державна доповідь про становище дітей в Україні (за період 2009-2016 рр.). - Київ, 2016. $160 \mathrm{c}$.

9. Nieuwenhuis R., Maldonado L.C. The triple bind of single-parent families: resources, 1 employment and policies // The Triple Bind of Single-Parent Families: Resources, Employment and Policies to Improve Well-being 1st Edition. - Policy Press, 2018. - 304 p.

10. France Income support (RSA) // European Commission. Employment, Social Affairs \& Inclusion [Електронний ресурс]. - Режим доступу: https://ec.europa.eu/social/main.jsp?catId=1110\& langId=en\&intPageId=4541 (дата звернення: 01.02.2019).

11. Morissens Ann. The role of universal and targeted family benefits in 359 reducing poverty in single-parent families in different employment situations // The Triple Bind of Single-Parent Families: Resources, Employment and Policies to Improve Well-being 1st Edition. - Policy Press, 2018. - P. 359-383.

12. Бориченко K.B. Соціальний захист сімей з дітьми за законодавством України. - Одеса: Фенікс, 2015. $-302 \mathrm{c}$.

13. Doing better for families // OECD Publishing. - 2011. - doi: https://doi.org/10.1787/ 9789264098732-en.

14. Duyulmus C.U., Van den Berg A. Single Parent Families and Poverty in Continental Welfare States: Examining Dutch Policy Responses to New Social // Department of Sociology McGill University [Електронний ресурс]. - Режим доступу: http://aei.pitt.edu/79001/1/Duyulmus.van_den_Berg. pdf (дата звернення: 04.02.2019).

15. Аналітичне дослідження участі жінок у складі робочої сили України / ЮНФПА, УЦСР. Київ, 2011. - 212 с. [Електронний ресурс]. - Режим доступу: https://www.idss.org.ua/monograf ii/2013_ua_womens\%20participation.pdf (дата звернення: 01.02.2019).

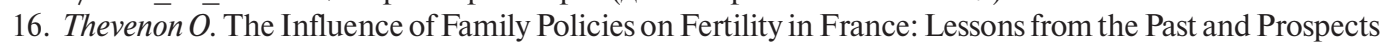
for the Future // Low Fertility, Institutions, and their Policies. - 2016. - P. 49-76.

\section{REFERENCES}

1. Sliusar, L.I. (2017). Spetsyfika batkivstva u sim'iakh riznykh typiv: problemy, ryzyky ta shliakhy yikh minimizatsii [Specificity of parenthood in family of different types: problems, risks and their ways of minimization]. Demohrafiia ta sotsialna ekonomika - Demography and social economy, 3(31), 24-36. https://doi.org/10.15407/dse2017.03.024 [in Ukrainian].

2. Carlson, L, Oláh, L.S., \& Hobson, B. (2017). Policy recommendations Changing families and sustainable societies: Policy contexts and diversity over the life course and across generations. Families and Societies project consortium. Retrieved from http://www.familiesandsocieties.eu/wp-content/uploads/2017/06/ WorkingPaper78.pdf

3. Bonoli, G. (2005). The Politics of the New Social Policies: Providing Coverage Against New Social Risks in Mature Welfare States. Policy \& Politics, 33, 431-449.

4. Sliusar, L.I. (2018). Pozashliubna narodzhuvanist v Ukraini: suchasni osoblyvosti v konteksti yevropeiskoho rozvytky [Non-marital fertility in ukraine: modern features in the context of european demographic development]. Demohrafiia ta sotsialna ekonomika - Demography and social economy, 3(34), 26-38. - https://doi.org/10.15407/dse2018.03.026 [in Ukrainian].

5. Family size and household composition (2016). OECD Family Database. Retrieved from www.oecd. org/els/family/database.htm

6. Sliusar, L.I. (2016). Batkivstvo u systemi vidnosyn instytutu sim'i: suchasni transformatsii, yikh prychyny ta naslidky [Parenthood in the System of Relations of Family Institute: Modern Transformations, their Causes and Consequences]. Demohrafiia ta sotsialna ekonomika - Demography and social economy, 2(27), 26-38. - https://doi.org/10.15407/dse2016.02.026 [in Ukrainian]. 
7. Camootsinka domohospodarstvamy Ukrainy rivnia svoikh dokhodiv (za danymy vybirkovoho opytuvannia domohospodarstv u sichni 2017 roku ) [Household Self-Assessment of Their Income Level in January 2017] (2017). State Statistics Service of Ukraine. Kyiv [in Ukrainian].

8. Realizatsiia konventsii OON pro prava dytyny v Ukraini: dosiahnennia, problemy, perspektyvy : derzhavna dopovid pro stanovyshche ditei v Ukraini (za period 2009-2016 rr.) [State Report on the Situation of Children in Ukraine «Implementation of the UN Convention on the Rights of the Child in Ukraine: Achievements, Problems, Prospects» (for the period of 2009-2016)]. (2016). Ministry of Social Policy of Ukraine, NGO «Ukrainian Institute of Social Research named after Alexander Yaremenko». Kyiv [in Ukrainian]

9. Nieuwenhuis, R., \& Maldonado, L.C. (2018). The triple bind of single-parent families: resources, 1 employment and policies. The Triple Bind of Single-Parent Families: Resources, Employment and Policies to Improve Well-being 1st Edition. Policy Press.

10. France Income support (RSA). (n.d.). European Commission. Employment, Social Affairs \& Inclusion Retrieved from https://ec.europa.eu/social/main.jsp?catId=1110\&langId=en\&intPageId=4541

11. Morissens, A. (2018). The role of universal and targeted family benefits in 359 reducing poverty in singleparent families in different employment situations. The Triple Bind of Single-Parent Families: Resources, Employment and Policies to Improve Well-being 1st Edition. Policy Press.

12. Borychenko, K.V. (2015). Sotsialnyi zakhyst simei z ditmy za zakonodavstvom Ukrainy: монографiя [Social protection of families with children under the legislation of Ukraine]. Odessa: Feniks [in Ukrainian].

13. Doing better for families (2011). OECD Publishing. - https://doi.org/10.1787/9789264098732-en

14. Duyulmus, C.U., \& Van den Berg, A. (2015). Single Parent Families and Poverty in Continental Welfare States: Examining Dutch Policy Responses to New Social. Department of Sociology McGill University Retrieved from http://aei.pitt.edu/79001/1/Duyulmus.van_den_Berg.pdf

15. Analitychne doslidzhennia uchasti zhinok u skladi robochoi syly Ukrainy [Analytical research on women's participation in the labour force in Ukraine] (2011). Retrieved from https://www.idss.org.ua/monografii/2013_ua_womens\%20participation.pdf [in Ukrainian].

16. Thevenon, O. (2016). The Influence of Family Policies on Fertility in France: Lessons from the Past and Prospects for the Future. Low Fertility, Institutions, and their Policies, 49-76.

Стаття надійшла до редакції 13.02.2019. 


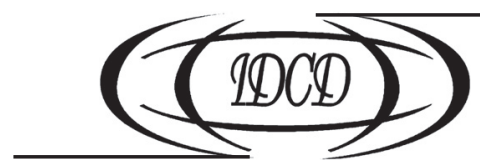

https://doi.org/10.15407/dse2019.02.052

УДК 314.14:311.15] (477)

JEL CLASSIFICATION: J11

\section{Н.М. ЛЕВЧУК}

д-р екон. наук, старш. наук. співроб., голов. наук. співроб.

Інститут демографії та соціальних досліджень

ім. М.В. Птухи НАН України

01032, Україна, м. Київ, бул. Т. Шевченка, 60

E-mail: levchuk.nata@gmail.com

ORCID 0000-0003-4944-684X

\section{Л.В. ЛУЩИК}

голов. економіст

Інститут демографії та соціальних досліджень

ім. М.В. Птухи НАН України

01032, Україна, м. Київ, бул. Т. Шевченка, 60

E-mail: lvluschik@ukr.net

ORCID 0000-0001-5425-3482

\section{НЕРІВНІСТЬ У ПОРЯДКУ ВИМИРАННЯ Й ДОЖИТТЯ УМОВНИХ ПОКОЛІНЬ В УКРАЇНІ}

Досягнення високих показників тривалості життя у західному світі супроводжується суттєвими змінами у порядку вимирання населення та характеру кривої дожиття. Зокрема, числа тих, хто доживають до певного віку, збільшуються з кожним новим поколінням, унаслідок чого крива дожиття поступово наближається до прямокутної форми, тобто відбувається так званий процес ректангуляціi кривої дожиття та компресія смертності. Проте в Україні ці процеси є малодослідженими. Уданій роботі на основі зарубіжного досвіду апробовано й розраховано для України ряд індикаторів, які дали змогу оцінити міру нерівності у порядку вимирання за віком стаціонарного населення, а саме: коефіцієнт Джині, середню різницю у віці смерті індивідів із табличного населення, квартильний розмах у порядку дожиття умовних поколінь. Аналіз зазначених показників виявив: а) загальну тенденцію до послаблення міжкіндивідуальної нерівності у порядку дожиття табличного населення після 2000-го року; б) нерівномірніший розподіл доживаючих за віком у періоди нижчої тривалості життя та в регіонах України, де очікувана тривалість життя при народженні є нижчою. Моделювання гіпотетичних варіантів кривої Лоренца і коефіцієнта Джині залежно від різних повікових зрушень у смертності населення показало, що величина даного коефіцієнта найбільш чутлива до змін смертності в працездатному віці $i$ досягає мінімальних значень, коли все більше смертей концентруються навколо середнього віку смерті. Виявлено повікові особливості розподілу життєвого потенціалу, прожитого умовним поколінням за статтю, зокрема вищу нерівномірність у порядку вимирання й дожиття чоловіків порівняно з жінка-

С ЛЕВЧУК Н.М., ЛУЩИК Л.В., 2019 
ми. Розподіл доживаючих за віком та величина квартильного розмаху, обчисленого за даними таблиць смертності й тривалості життя України, свідчить, що $50 \%$ із умовного покоління чоловіків вмирає в інтервалі віку між 58 і 79 років (за 21 рік), а у жінок-між 71 і 87 років життя (за 15 років), тобто жінки доживають до старшого віку, але концентрація смертей між першим і третім квартилями стає інтенсивнішою. Це вказує на те, що темпи процесу компресії смертності й ректангуляції кривої дожиття у жінок виражені сильніше, ніж у чоловіків.

Ключові слова: смертність, нерівність крива Лоренца, коефіцієнт Джсині, квартильний розмах.

\section{H.М. Левчук}

д-р экон. наук, глав. науч. сотруд.

Институт демографии и социальных исследований

им. М.В. Птухи НАН Украины

01032, Украина, г. Киев, бул. Т. Шевченка, 60

E-mail: levchuk.nata@gmail.com

ORCID 0000-0003-4944-684X

\section{Л.В. Лущик}

глав. экономист

Институт демографии и социальных исследований

им. М.В. Птухи НАН Украины

01032, Украина, г. Киев, бул. Т. Шевченка, 60

E-mail: lvluschik@ukr.net

ORCID 0000-0001-5425-3482

\section{НЕРАВЕНСТВО В ПОРЯДКЕ ВЫМИРАНИЯ И ДОЖИТИЯ УСЛОВНЫХ ПОКОЛЕНИЙ В УКРАИНЕ}

Достижение высоких показателей продолжительности жизни в западном мире сопровождается существенными изменениями в порядке вымирания населения и характера кривой дожития. В частности, числа тех, кто доживает до определенного возраста, увеличиваются с каждым новым поколением, в результате чего кривая дожития постепенно приближается к прямоугольной форме, то есть происходит так называемый процесс ректангуляции кривой дожития и компрессия смертности. Эти процессы мало исследованы в Украине. В данной работе на основе существующего зарубежного опыта апробирован и рассчитан для Украины ряд индикаторов, позволивших оценить меру неравенства в порядке повозрастного вымирания стационарного населения, а именно: коэффициент Джини, среднюю разнииу в возрасте смерти индивидов табличного населения, квартильный размах в порядке дожития условных поколений. Анализ указанных показателей помог установить: а) общую тенденцию к ослаблению межиндивидуального неравенства в порядке дожития табличного населения после 2000-го года, б) более неравномерное распределение доживающих по возрасту в периоды низкой продолжительности жизни и в регионах, где ожидаемая продолжительность жизни при рождении ниже. Моделирование гипотетических вариантов кривой Лоренца и коэффициента Джини в зависимости от разных повозрастных сдвигов в смертности населения показало, что величина данного коэффициента наиболее чувствительна к изменениям смертности в трудоспособном возрасте и достигает минимальных значений, когда все больше смертей концентрируются вокруг среднего возраста смерти. Выявлены повозрастные особенности распределения жсизненного потенциала, прожитого условным поколением $в$ зависимости от пола, в частности большую неравномерность в порядке вымирания и дожития мужчин по сравнению с женщинами. Распределение доживающих по возрасту и величина межквартильного размаха, исчисленного по данным таблии смертности и продолжительности жсизни, свидетельствует о том, что 50 \% условного поколения мужчин умирает в интервале возраста между 58 и 79 годами (за 21 год), а у женщин - между 71 и 87 годами жизни (за 15 лет), то есть женщины доживают до старшего возраста, но концентрация смертей между первым и третьим квартилями становится более интенсивной. Это указывает на то, что темпы процесса компрессии смертности и ректангуляции кривой дожития у женщин выражены сильнее, чем у мужчин.

Ключевые слова: смертность, неравенство, кривая Лоренца, коэффициент Джсии, квартильный размах. 


\author{
N.M. Levchuk \\ Dr. (Economics), Chief Researcher, Ptoukha Institute for Demography \\ and Social Studies of the National Academy of Sciences of Ukraine \\ 01032, Ukraine, Kyiv, Taras Shevchenko Blvd., 60 \\ E-mail: levchuk.nata@gmail.com \\ ORCID 0000-0003-4944-684X
}

\title{
L.V. Luschik
}

Leading Economist

Dr. (Economics), Chief Researcher, Ptoukha Institute for Demography

and Social Studies of the National Academy of Sciences of Ukraine

01032, Ukraine, Kyiv, Taras Shevchenko Blvd., 60

E-mail: lvluschik@ukr.net

ORCID 0000-0001-5425-3482

\section{INTER-INDIVIDUAL INEQUALITY IN LENGTH OF LIFE IN UKRAINE}

The progress in life expectancy and reduction of mortality in developed countries are driven by profound changes in age distribution of deaths and so called historical compression of mortality. Mortality compression causes a rectangularization of the lifetime survival function when more and more cohorts survive until advanced ages. It is important to examine how equally the gain in life span is distributed across individuals in population and to define the degree of inter-individual inequality in life expectancy. Little is known about these processes in Ukraine. In this paper inter-individual inequality in life expectancy in Ukraine is examined through the following measures: Gini coefficient, average inter-individual difference in age at death (absolute measure corresponding to Gini), and inter-quartile range. They are defined on the length-of-life distribution. We found that: a) there has been a decline in inter-individual inequality in length of life in Ukraine since the 2000s; b) the degree of inequality in length of life is higher when life expectancy tends to decrease. Modeling and testing the Lorenz curves for life tables with different mortality patterns revealed that variations in Gini coefficient are most sensitive to changes in level and age distribution of mortality at working ages and tends to a minimum when more deaths is concentrated around the mean age at death. In 2017, the lowest values of Gini coefficient were detected in Ternopil, IvanoFrankivsk and Chernivtsi oblasts while its highest values were observed in Kirovograd, Zhytomyr and Chernigiv oblasts. Analysis of life tables and calculation of interquartile range show that age distribution of deaths in men is more unequal than that in women. 50\% of males die between the ages of 58 and 79 years that is during 21 years while $50 \%$ offemales die between 71 to 87 years that is during 15 years. Not only do the women die at more advanced ages and live longer than men but also they have much higher death concentration between the first and the third quartiles. This indicates that historical compression of mortality and rectangularizations effects are more pronounced for women than for men.

Keywords: mortality, inter-individual-inequality, Lorenz curve, Gini coefficient, inter-quartile range.

Постановка проблеми та актуальність теми. Після Другої Світової війни у розвинутих країнах унаслідок так званої епідеміологічної революції відбулися суттєві зміни у структурі причин смерті населення та повіковій смертності i, як наслідок, підвищення тривалості життя. 3 середини 1960 -х років тривалість життя у країнах західної Європи кожні 10 років збільшувалась щонайменше на два роки. Прогрес у тривалості життя супроводжувався ректангуляцією кривої дожиття $\left(l_{x}\right)$, тобто набуттям нею все більш прямокутної форми. Це відбувалося за рахунок так званої компресії смертності, іiї «стискання» у дедалі вужчому віковому інтервалі, тобто все більшої концентрації смертей у похилому віці [1]. Ці процеси тривають дотепер у більшості країн світу. Темпи змін можуть бути швидкими чи повільними; компресія смертності у дорослому віці може компенсуватися декомпресією у молодому [2]. Перспектива набуття кривої дожиття повністю прямокутної форми означає, що смертність буде спричинена лише генетично обумовленими факторами, а смерті від екзогенних причин зникнуть [2, 3]. 
У зв’язку з цими зрушеннями дослідники почали вивчати не лише динаміку тривалості життя, а й нерівність між індивідами щодо ризику смерті й тривалості життя. Якщо міжгрупова нерівність у тривалості життя (inter-group inequality in life expectancy) характеризує відмінності у показниках поміж групами, виділеними за певними спільними соціально-економічними ознаками (освіта, дохід, зайнятість, шлюбний статус, місце проживання тощо), то міжіндивідуальна нерівність у тривалості життя (inter-individual inequality in life expectancy) оцінює відмінності у показниках смертності між усіма індивідами у складі населення, коли кожний індивід порівнюється 3 іншими [4]. Питання, яке нині ставлять дослідники, можна сформулювати так: яку тривалість життя яка частка теоретичного населення таблиці смертності матиме? Іншими словами, необхідно оцінити, наскільки однаково чи неоднаково довго живе умовне покоління таблиці смертності, i, відповідно, населення певного регіону чи країни, для яких ця таблиця смертності побудована [5]. Адже одні люди вмирають у молодому віці, тобто вони є «бідними» у термінах тривалості життя, а інші доживають до старшого віку і є «багатими» щодо прожитих років життя.

Відомо з різних досліджень, що тривалість життя в Україні суттєво нижча, ніж у країнах Західної Європи, і їі динаміка за останні півстоліття відзначалася вираженими коливаннями. Значно менш поширеними в Україні є роботи з моделювання показників таблиць смертності з метою вивчення повікових характеристик процесу дожиття умовних поколінь у часі та просторі та їх впливу на рівень тривалості життя при народженні. Такі дослідження дають змогу, по-перше, оцінити нерівність у термінах прожитих років життя; по-друге, з’ясувати, що відбувається за зростання чи падіння тривалості життя: посилення чи послаблення нерівності.

Аналіз наявних досліджень. Серед різних показників, які вимірюють міжіндивідуальну нерівність у порядку вимирання й дожиття умовних поколінь, найпоширенішими є коефіцієнт Джині та квартильний розмах. Відомі дослідження вказують, що прогрес у тривалості життя в розвинутих країнах у довготривалій ретроспективі супроводжувався послабленням міжіндивідуальної нерівності у порядку дожиття. Дж. Уілмот (J. Wilmoth) та С. Хоріучі (S. Horiuchi) (1999) [1] пояснюють це насамперед зниженням смертності у дитячому й молодому віці. Однак упродовж останніх трьох десятиліть попри подальше повільне зростання тривалості життя показники нерівності в розвинутих країнах перестали знижуватись. Тобто вони сягнули певного низького рівня і подальший спад коефіцієнта Джині припинився. До того ж у багатьох країнах виразнішим став спад смертності у старших вікових групах, що також дещо загальмувало зниження показника Джині [6, с. 338]. В Україні дослідження нерівності у порядку дожиття за допомогою коефіцієнта Джині й міжквартильного розмаху дотепер не проводили.

Мета статті - дослідити нерівність у порядку вимирання й дожиття умовних поколінь в Україні та виявити особливості ії динаміки в часовому та регіональному розрізах.

Новизна роботи: уперше виконано оцінку міжіндивідуальної нерівності у порядку дожиття табличного населення України на основі відомих індикаторів - коефіцієнта Джині, квартильного розмаху, а також графічного зображення нерівномірності розподілу - кривої Лоренца.

Дані. Дослідження базується на даних Державної служби статистики України, зокрема щорічних таблицях смертності й очікуваної тривалості життя України та iii регіонів за окремі роки. Також використано таблиці смертності, побудовані для Швеції (Human Mortality Database). 
Метод. Коефіцієнт Джині є найпоширенішим статистичним показником, що вимірює ступінь диференціації розподілу, набуваючи значень між 0 i 1 , де 0 означає абсолютну рівність, а 1 - повну нерівність. Найчастіше його застосовують для вимірювання нерівності населення за доходами на основі аналізу розподілу доходів серед окремих верств населення чи груп домогосподарств. Коефіцієнт Джині розраховують за спеціальними формулами за допомогою кривої Лоренца, яка показує фактичний розподіл доходів між групами домогосподарств / індивідів за певний період часу. Якщо дохід є рівномірно розподіленим, то крива Лоренца збігається із діагоналлю повної рівності (прямою під кутом 45), і значення коефіцієнта Джині дорівнює нулю. Чим більше крива відхиляється від лінії абсолютної рівності, тим більшим є ступінь нерівномірності (диференціації) у розподілі доходів. Смертність й тривалість життя також можна представити у площині нерівності щодо шансів вижити, оскільки одні індивіди вмирають раніше за інших, тобто є «бідними» щодо шансів на довге життя, інші живуть довше.

P. Iлсей (R. Illsey) та Дж. Ле Гранд (J. Le Grand) (1987) [7] обгрунтували використання коефіцієнта Джині на основі реального розподілу померлих. Інші дослідники розраховують коефіцієнт Джині на основі показників стаціонарного населення із таблиць смертності $[1,8]$. У цьому разі крива Лоренца відображає нерівність у порядку дожиття теоретичного покоління таблиці і будується згідно з розподілом дожиття за віком смерті, де по осі $X$ відкладена кумулятивна частка населення $\left(F_{x}\right)$, а по осі $Y$ - кумулятивна частка прожитих людино-років $\left(\Phi_{x}\right)$. Розподіл померлих $є$ рівномірним i нерівності немає, коли, скажімо, 10 \% табличного населення (прийнятого зазвичай за 100000 у таблиці смертності) проживає $10 \%$ від сукупної кількості людино-років життя, яку проживає це покоління ( $\mathrm{T}_{0}$ із таблиці смертності), 20 \% табличного населення - $20 \%$ від сукупної кількості прожитих людино-років і т. д. Нерівність у порядку дожиття є вираженою, коли рівномірний розподіл порушується, і смерті концентруються у якомусь віковому інтервалі, наприклад, у разі високої смертності немовлят та дітей, або навпаки, у разі концентрації усіх смертей у похилому віці. Тобто коефіцієнт Джині вимірює ступінь нерівномірності у порядку дожиття табличного населення, але причини нерівномірності можуть бути різними.

У нашому дослідженні ми скористалися геометричним підходом до обчислення коефіцієнта Джині $G_{x}$ - тобто це площа між кривою Лоренца і лінією повної рівності (прямою під кутом $45^{\circ}$ ), поділена на площу нижнього трикутника:

$$
\mathrm{G}=1-\sum_{i=0}^{n-1}\left(\mathrm{~F}_{i+1}-\mathrm{F}_{i}\right) \times\left(\Phi_{i+1}+\Phi_{i}\right)
$$

При цьому накопичені частки населення $F_{x}$ і відповідні частки прожитих ним людино-років життя $\Phi_{x}$ у формулі (1) обчислюються так:

$$
F_{x}=\frac{\sum_{t=0}^{x} d_{t}}{\sum_{t=0}^{\infty} d_{t}}=1-\frac{l_{x}}{l_{0}}, \quad \text { (2) } \quad \Phi_{x}=\frac{\sum_{t=0}^{x} d_{t} \cdot \bar{t}}{\sum_{t=0}^{\Phi} d_{t} \cdot \bar{t}},
$$


де $d_{t}, l_{x}, \bar{t}-$ показники з таблиць смертності: $d_{t}$ - табличне число померлих у віці $t$; $l_{x}$ - число тих, хто доживає до віку $x ; \bar{t}-$ середній вік померлих у даній віковій групі.

Коефіцієнт Джині - це відносний показник, а його еквівалентом в абсолютному вимірі є показник $A I D_{x}$, (average inter-individual difference in length of life), що позначає середню абсолютну різницю у віці смерті індивідів із складу теоретичного покоління відносно середньої тривалості життя [6]. Цей показник вимірюється в роках і розраховується за формулою:

$$
A I D=G_{0} \times e_{o},
$$

де $e_{o}$ - очікувана тривалість життя при народженні.

Ще одним показником, який може бути використаний для оцінки ступеня нерівності у порядку дожиття, є квартильний розмах [1]. Це різниця між віком, до якого доживає $25 \%$ із теоретичного покоління таблиці (зазвичай, 100000 новонароджених), і віком, до якого доживає $75 \%$ із цього покоління. Тобто це відстань (різниця) між третім та першим квартилями розподілу за віком тих, хто доживає:

$$
I R Q=Q_{25}-Q_{75}
$$

де $Q_{25}=x$, коли $l_{x}=0,25 ; Q_{75}=x$, коли $l_{x}=0,75 ; x-$ вік з таблиць смертності.

Виклад основного матеріалу. Наші розрахунки показників Джині та AID для України за статтю за деякі роки представлені у табл. 1. Як бачимо, показник Джині $\left(G_{x} \times 100\right)$ в Україні є невисоким і становив в 2017 р. майже 14 для чоловіків та 10 для жінок. Проте в абсолютному виразі його величина, тобто величина $A I D, \epsilon$ значнішою. У 2017 р. різниця між індивідуальним віком смерті та середнім віком смерті умовного покоління становила в середньому 9,3 та 7,7 року для чоловіків і жінок відповідно.

Аналіз розрахованих показників Джині в Україні за вибрані роки свідчить про загальну тенденцію до зниження його рівня у періоди вищої тривалості життя та збільшення його рівня у роки відносно низької тривалості життя. Зокрема, у чоловіків у 1963 та 1983 рр. показники Джині були нижчими, ніж у 1995 та 2001 pp.

Таблиия 1. Показники нерівності у порядку дожиття умовних поколінь та середня тривалість життя в Україні

\begin{tabular}{|l|c|c|c|c|c|c|}
\hline \multirow{2}{*}{ Рік } & \multicolumn{2}{|c|}{$\begin{array}{c}\text { Коефіцієнт Джині } \\
\left(G_{x} \times \mathbf{1 0 0}\right)\end{array}$} & \multicolumn{2}{c|}{$A I D$, років життя } & \multicolumn{2}{c|}{$\begin{array}{c}\text { Середня тривалість життя } \\
\text { при народженні }\end{array}$} \\
\cline { 2 - 7 } & чоловіки & жінки & чоловіки & жінки & чоловіки & жінки \\
\hline 1933 & 63,94 & 67,17 & 3,197 & 5,407 & 5,00 & 8,05 \\
\hline 1963 & 15,99 & 13,00 & 10,762 & 9,557 & 67,32 & 73,50 \\
\hline 1983 & 15,96 & 11,46 & 10,339 & 8,516 & 64,78 & 74,30 \\
\hline 1991 & 15,59 & 11,09 & 10,072 & 8,245 & 64,62 & 74,32 \\
\hline 1995 & 16,97 & 11,96 & 10,387 & 8,675 & 61,22 & 72,54 \\
\hline 2001 & 16,43 & 11,34 & 10,240 & 8,348 & 62,32 & 73,63 \\
\hline 2013 & 14,47 & 10,39 & 9,595 & 7,919 & 66,32 & 76,20 \\
\hline 2017 & 13,88 & 9,98 & 9,304 & 7,659 & 67,02 & 76,78 \\
\hline
\end{tabular}

Джерело: авторські розрахунки за даними Держстату України. 
Відмінності у порядку дожиття в Україні та Швеції ілюструє рис. 1. У 1933 р., тобто у рік максимальної смертності від Голодомору, в Україні рівень коефіцієнт Джині досягнув 63,9 у чоловіків та 67,2 у жінок, і крива Лоренца дуже сильно відхилялася від діагоналі. Натомість у Швеції того року коефіцієнт Джині становив 20 у чоловіків та 18,3 у жінок. Така велика нерівність у порядку дожиття в Україні у рік екстраординарної смертності від голоду зумовлена як дуже великою концентрацією смертей у дитячому віці, так і високою смертністю осіб дорослого віку, тоді як у Швеції головну роль відігравала підвищена дитяча смертність. У 1933 р. на $60 \%$ табличного населення в Україні припадало лише 10-12 \% із загального числа прожитих людино-років, а у Швеції - 47-49\%.

У 1964 р. в обох країнах криві Лоренца відхиляються від діагоналі значно менше. Того року в Україні була доволі висока тривалість життя, і крива досить подібна до такої у Швеції. Нині ступінь нерівності у порядку дожиття в Україні є вищим, ніж
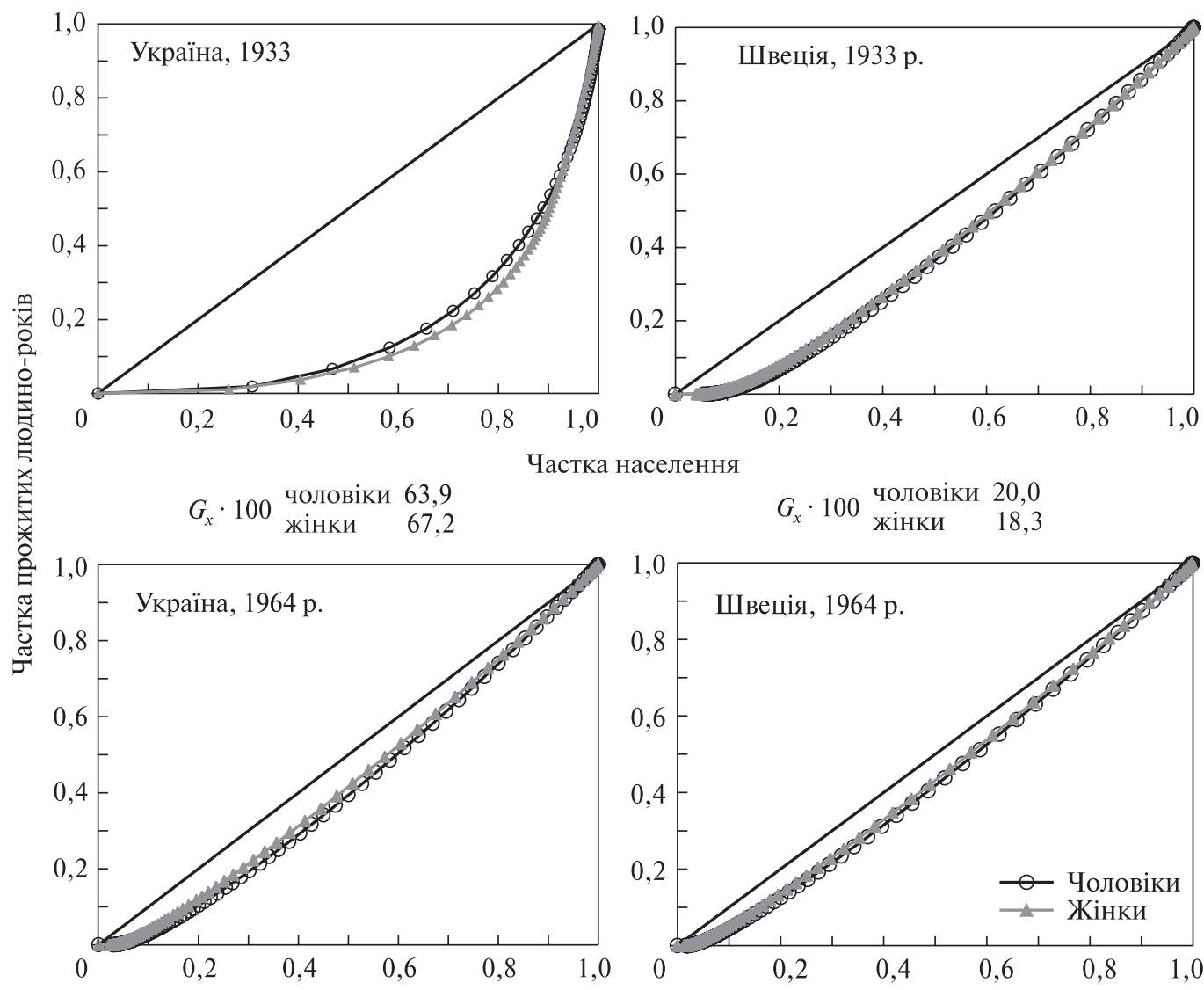

Частка населення

$$
G_{x} \cdot 100 \begin{array}{ll}
\text { чоловіки } & 15,6 \\
\text { жінки } & 12,6
\end{array}
$$

$$
G_{x} \cdot 100 \begin{array}{ll}
\underset{\text { чоловікий }}{\text { жінки }} & 12,1 \\
10,2
\end{array}
$$

Рис. 1. Крива Лоренца для порядку дожиття за віком в Україні та Швеції у 1933 та 1964 рр., за статтю

Джерело: авторські розрахунки за даними Держстату України та Human Mortality Database. 
у Швеції, відмінності між країнами поглибились порівняно з 1964 р. Окрім цього, на рис. 2 чітко видно, що криві Лоренца для чоловіків та жінок у Швеції майже збігаються, а в Україні зберігаються статеві відмінності, зумовлені надсмертністю чоловіків. Проте треба зазначити, що відмінності у тривалості життя при народженні між чоловіками й жінками в Україні значно більші, ніж розбіжності у показнику $A I D$.

Якщо розподіл померлих є рівномірним, то показники Джині і $A I D$ дорівнюють нулю. Теоретично, найбільшим досягненням є висока тривалість життя і мінімальна нерівність у порядку дожиття, тобто ситуація, коли усі доживають до похилого віку і вмирають в однаковому віці, іншими словами мають однаково високу тривалість життя й той самий вік смерті. У цьому випадку, крива Лоренца збігається з діагоналлю. Таку гіпотетичну криву зображено на рис. 3 для жінок України у 2017 р., якби 98 \% табличних смертей відбулися у віці 90 років і старше. У такому разі тривалість життя жінок при народженні досягнула б майже 94 років і коефіцієнт Джині дорівнював би 0.

Щоб з'ясувати, як буде змінюватися крива Лоренца і рівень коефіцієнта Джині залежно від різних повікових зрушень у смертності населення, було побудовано ще кілька моделей на основі базової таблиці смертності жінок України у 2017 р.: висока дитяча смертність (табличне число померлих у віці до 6 років збільшено у 10 разів), а у віці старше 6 років числа померлих залишаються майже без змін (рис. 4); висока смертність у молодому й середньому віці (рис. 5); збільшення числа померлих у віці 50-70 років та зменшення кількості померлих у молодому та середньому віці (рис. 6).

У першому варіанті, тобто за умови значного збільшення дитячої смертності, у жінок очікувана тривалість життя при народженні зменшується від 76,8 року до 71,3 року, а показник Джині збільшується від 10 до 17. Другий гіпотетичний варіант побудовано за умови збільшення табличного числа померлих у молодому та середньому
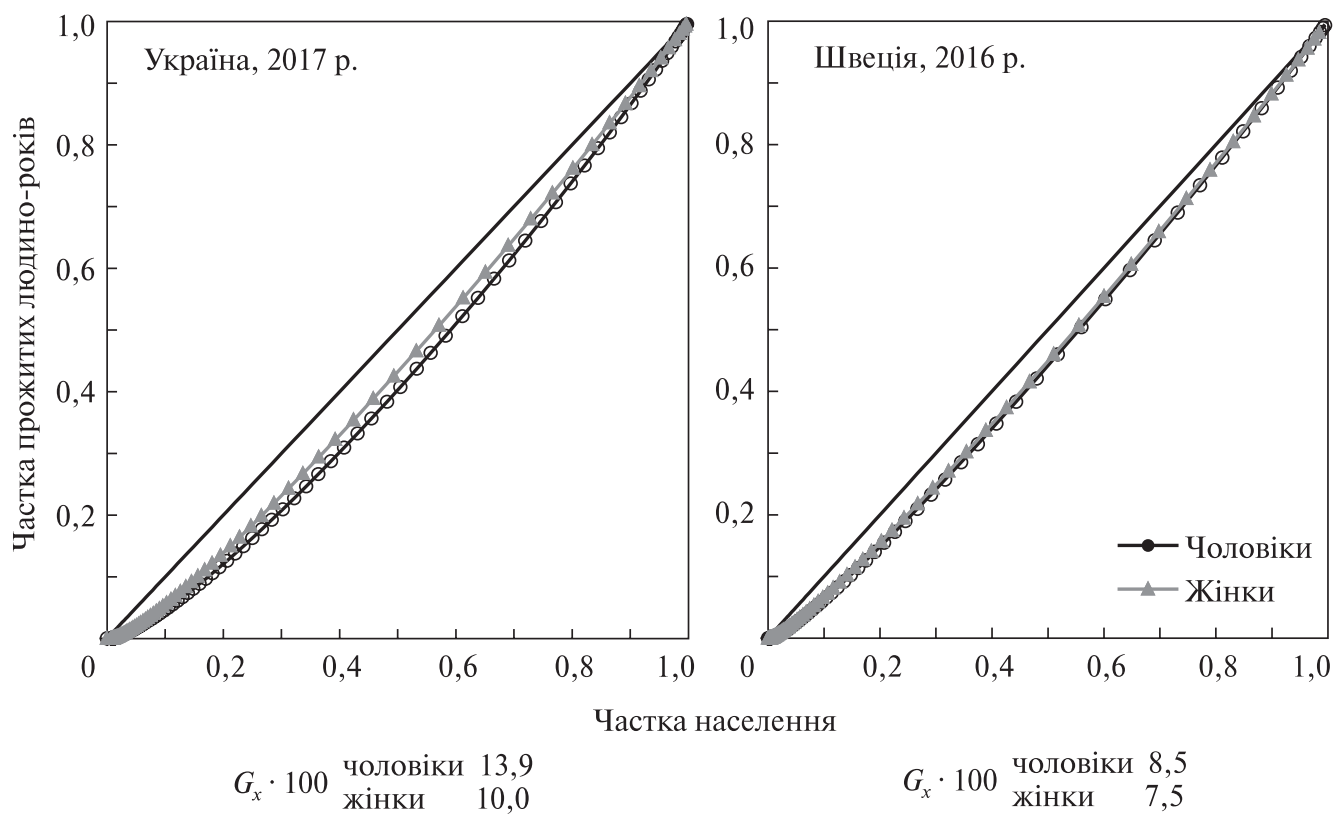

Рис. 2. Крива Лоренца для порядку дожиття за віком в Україні (2017) та Швеції (2016), за статтю Джерело: авторські розрахунки за даними Держстату України та Human Mortality Database. 

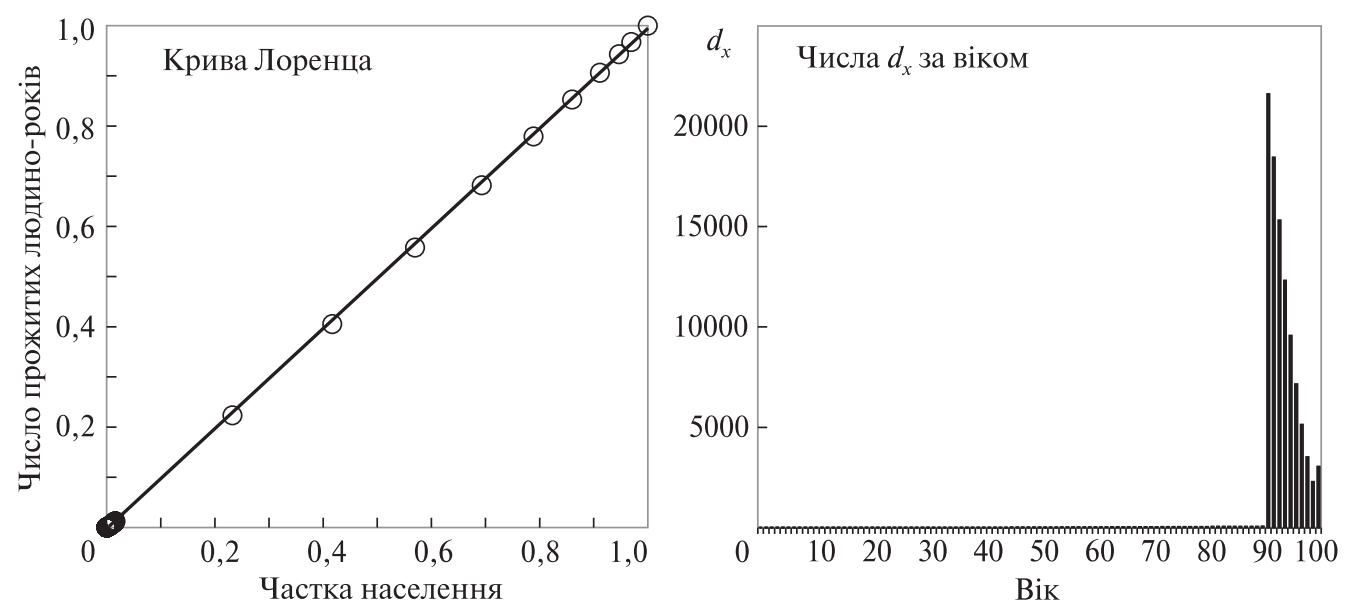

Pис. 3. Гіпотетична крива Лоренца для жінок України у 2017 р. за умови, коли $98 \%$ табличного числа померлих $\left(d_{x}\right)$ припадає на вік 90 років і старше, $e_{0}=93,8$ року, $\left(G_{x} \times 100\right)=0$

Джерело: авторські розрахунки за даними Держстату України.
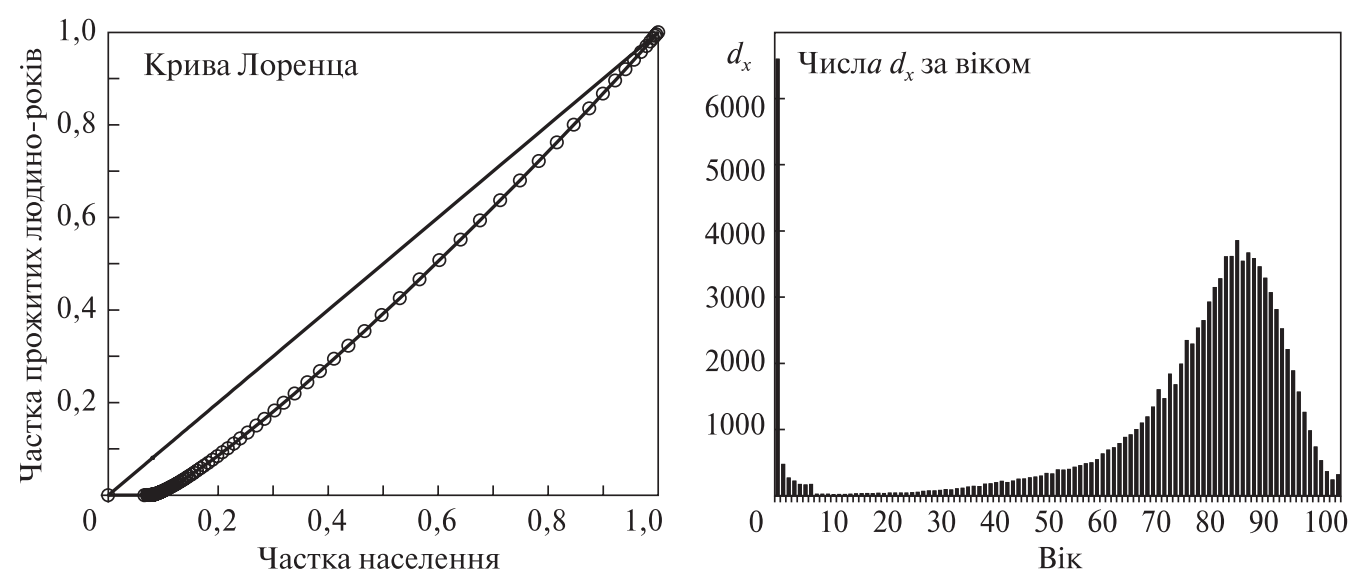

Рис. 4. Гіпотетична крива Лоренца для жінок України у 2017 р. за умови збільшення табличного числа померлих $\left(d_{x}\right)$ у віці до 6 років у 10 разів, $e_{0}=71,3$ року, $\left(G_{x} \times 100\right)=17,0$

Джерело: авторські розрахунки за даними Держстату України.

віці. При цьому смертність дітей віком до 6 років залишається без змін, а через високу смертність у молодому та середньому працездатному віці табличні числа померлих у віці 50 років і старше різко зменшуються. У цьому разі очікувана тривалість життя жінок при народженні становитиме лише 31,4 року, а коефіцієнт Джині зростає від 10 до 25,6. У третьому варіанті різко збільшується табличне число померлих у віці від 50 до 70 років, а смертність до 50 років, навпаки, знижується. Це призводить до деякого зменшення тривалості життя від 76,8 до 73,1 року, але при цьому рівень показника Джині змінюється несуттєво і становить 10,4.

Таким чином, вплив зрушень у повіковій смертності на показник Джині є неоднозначним. Модельні розрахунки свідчать про зворотній зв'язок між рівнем 

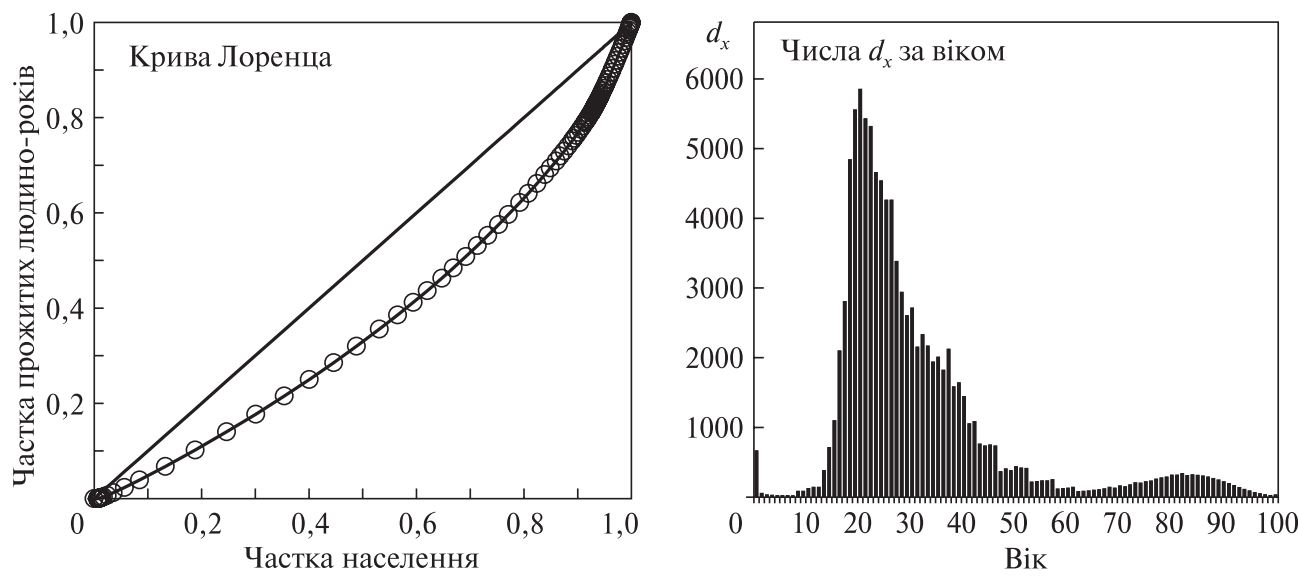

Рис. 5. Гіпотетична крива Лоренца для жінок України у 2017 р. за умови збілышення табличного числа померлих $\left(d_{x}\right)$ в інтервалі віку від 6 до 50 років, $e_{0}=31,4$ року, $\left(G_{x} \times 100\right)=25,6$

Джерело: авторські розрахунки за даними Держстату України.
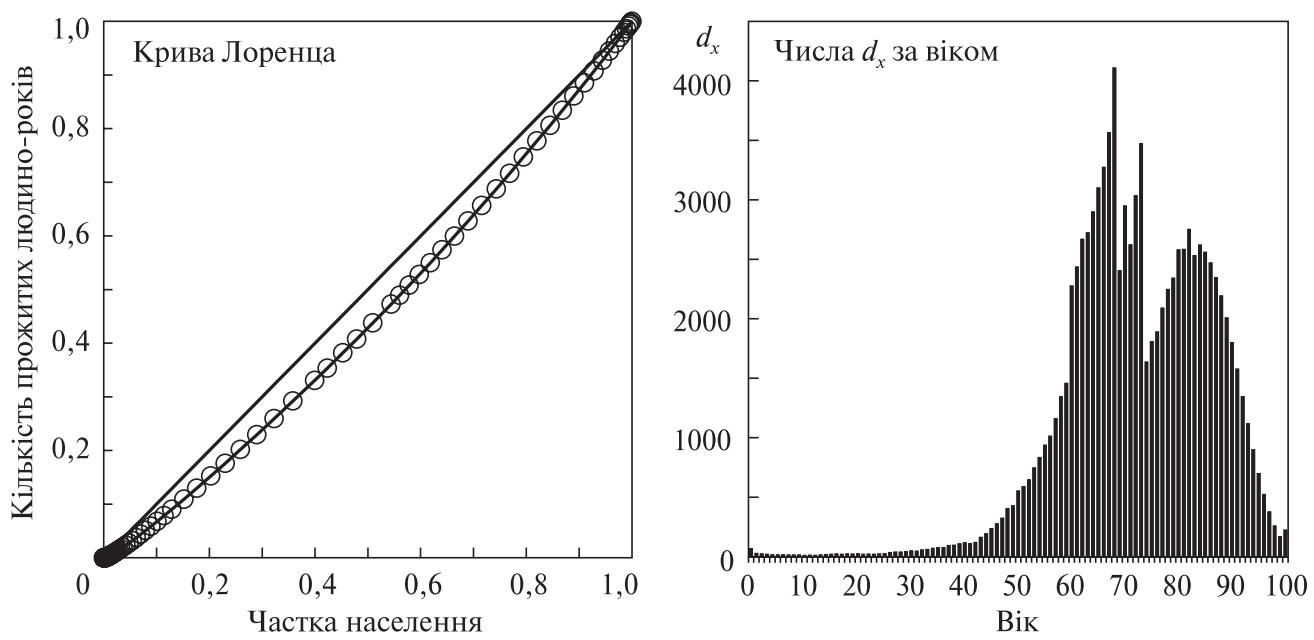

Рис. 6. Гіпотетична крива Лоренца для жінок України у 2017 р. за умови збілышення табличного числа померлих $\left(d_{x}\right)$ у віці від 50 до 70 років, $e_{0}=73,1$ року, $\left(G_{x} \times 100\right)=10,4$

Джкерело: авторські розрахунки за даними Держстату України.

тривалості життя та ступенем диференціації у розподілі тих, хто доживає. Зазвичай, чим нижча тривалість життя, тим вища нерівність у порядку дожиття. Ця нерівність зменшується, коли збережені життя припадають на більш ранні вікові групи і відбувається відсунення смертей у старші вікові групи, тобто компресія розподілу смертей у бік старших вікових груп. Коефіцієнт Джині мінімальний тоді, коли все більше смертей концентруються навколо середнього віку смерті. У результаті аналізування запропонованих нами трьох варіантів визначено, що показник Джині найчутливіший до змін смертності саме у трудоактивному віці. 


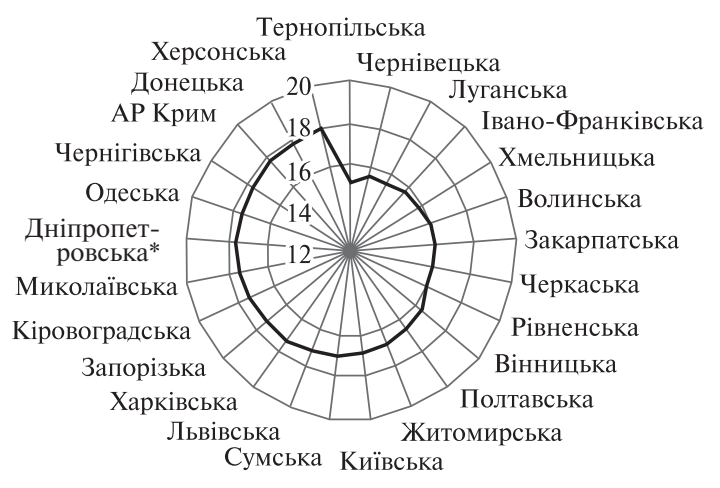

$a$

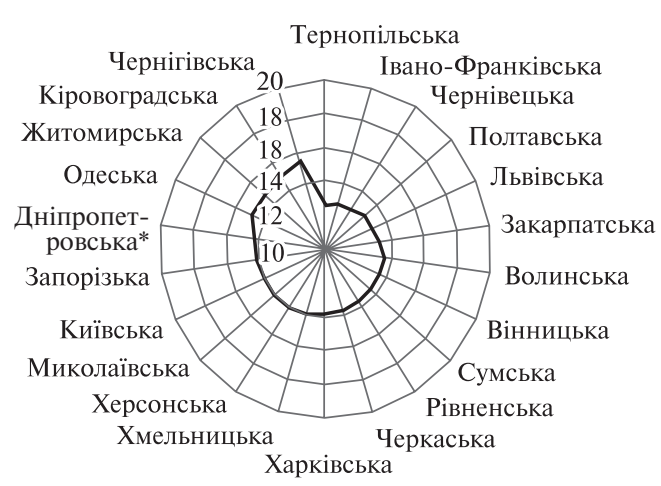

$\sigma$

Рис. 7. Коефіцієнт Джині $\left(G_{x} \times 100\right)$ по областях України, чоловіки: $a-1995$ р., $\sigma-2017$ р.

Джерело: авторські розрахунки за даними Держстату України.

* Примітка. Дніпропетровську обл.. з 2919 р. переіменовано на Січеславську.

Нами було також розраховано показники Джині та $A I D$ для областей України за окремі роки $(1991,1995,2001,2017)^{1}$. Вони показали, по-перше, що розподіл смертей і тих, хто доживає, більш нерівномірний у регіонах із нижчою тривалістю життя. Зокрема, найнижчий коефіцієнт Джині спостерігається у Тернопільській, Івано-Франківській та Чернівецькій областях; найвищий - у Кіровоградській, Житомирській та Чернігівській областях (рис. 7). По-друге, аналіз виявив загальну тенденцію до послаблення міжіндивідуальної нерівності у порядку дожиття табличного населення регіонів після 2000-го року. У 2017 р. порівняно з 1995 р. області стали більш подібними між собою за рівнем коефіцієнта Джині.

Ще одним показником нерівності у порядку дожиття є квартильний розмах у порядку дожиття (IQR). Нагадаємо, що це відстань (різниця) між третім та першим квартилями розподілу за віком тих, хто доживає (табл. 2).

Проведені розрахунки показали, що у 1991 р. в Україні 75 \% табличного населення чоловіків доживало до 55 років, а жінок - до 69 років; $25 \%$ табличного населення чоловіків доживало до 78 років, жінок - до 85 років. У середині 1990-х ці показники погіршилися. Останніми роками вік, до якого доживає дві третини табличного населення, дещо підвищився і становив у 2017 р. 58 років для чоловіків та 71 рік для жінок, а вік, до якого доживає лише чверть умовного покоління, -79 років для чоловіків та 87 років для жінок. Як наслідок, $50 \%$ із табличної сукупності чоловіків умирає протягом 21-го року в інтервалі віку 58 -79 років, а жінок - упродовж 15 років, між 71 і 87 роками життя. Це свідчить про виразні відмінності порядку дожиття в Україні між чоловіками та жінками. Жінки не просто живуть довше, у них компресія або концентрація смертей навколо середнього віку смерті виражена значно сильніше, тобто 50 \% смертей умовного покоління відбуваються на вужчому віковому інтервалі, ніж у чоловіків.

\footnotetext{
${ }_{1}$ У Необхідно також взяти до уваги погіршення якості регіональної демографічної статистики за останні роки через значну віддаленість від останнього перепису та наслідки збройного конфлікту з Російською Федерацією.
} 
Таблиця 2. Показники дожиття за віком та квартильний розмах (IQR) у порядку дожиття в Україні за окремі роки, за статтю

\begin{tabular}{|l|c|c|c|c|c|c|}
\hline \multicolumn{1}{|c|}{ Показник } & \multicolumn{3}{|c|}{ Чоловіки } & \multicolumn{3}{c|}{ Жінки } \\
\cline { 2 - 8 } & $\mathbf{1 9 9 1}$ & $\mathbf{1 9 9 5}$ & $\mathbf{2 0 1 7}$ & $\mathbf{1 9 9 1}$ & $\mathbf{1 9 9 5}$ & $\mathbf{2 0 1 7}$ \\
\hline $\begin{array}{l}\text { Вік, до якого доживає 75\% табличного на- } \\
\text { селення }\end{array}$ & 55,4 & 50,8 & 58,0 & 68,6 & 66,3 & 71,1 \\
\hline $\begin{array}{l}\text { Вік, до якого доживає 25\% табличного на- } \\
\text { селення }\end{array}$ & 78,0 & 75,1 & 79,1 & 84,8 & 83,7 & 86,6 \\
\hline Квартильний розмах & 22,56 & 24,43 & 21,1 & 16,2 & 17,4 & 15,45 \\
\hline
\end{tabular}

Джерело: авторські розрахунки за даними Держстату України.

Як наслідок, рівень нерівності у порядку дожиття жінок виражений меншою мірою, ніж у чоловіків: 25 \% умовного покоління проживає 16 \% накопиченого життєвого потенціалу у чоловіків та $18 \%$ - у жінок; $75 \%$ умовного покоління проживає $67 \%$ та $71 \%$ із загальної кількості людино-років, прожитих чоловіками та жінками відповідно. Поки що суттєвого зближення між чоловіками й жінками щодо компресії смертності й нерівності у порядку дожиття в Україні не відбулося.

Висновки. У цьому дослідженні ми розрахували й проаналізували показники Джині та квартильного розмаху, які дають уявлення про міру нерівності у порядку дожиття умовних поколінь в Україні. Вони враховують два чинники: рівень смертності та повікову модель вимирання умовного покоління. Показник тривалості життя вказує середню «довжину життя», а показники нерівності - нерівномірність у розподілі тих, хто вимирає / доживає до певного віку. Виявлено загальну тенденцію до послаблення міжіндивідуальної нерівності у порядку дожиття табличного населення України, про що свідчить зниження рівня коефіцієнта Джині після 2000-го року. Вищий показник Джині й відповідно нерівномірніший розподіл смертей і тих, хто доживає, спостерігався у періоди нижчої тривалості життя. Аналіз показників квартильного розмаху засвідчив також суттєві відмінності між чоловіками та жінками щодо порядку дожиття табличного населення, зокрема більшу нерівномірність у формуванні життєвого потенціалу чоловіків і вищі темпи компресії смертності у жінок.

\section{ЛІТЕРАТУРА}

1. Wilmoth J.R. and Horiuchi S. Rectangularization revisited: Variability of age at death with human populations // Demography. - 1999. - 36 (4). - P. 475-495. - https://doi.org/10.2307/2648085

2. Kannisto V. Measuring the Compression of Mortality // Demographic Research. - 2000. - Vol. 3, Art. 6. -24 p. - https://doi.org/10.4054/DemRes.200.3.6

3. Fries J.F. Aging, natural death and the compression of morbidity // New England Journal of Medicine. - 1980. - 303. - P. 130-135. - https://doi.org/10.1056/NEJM19800717303030

4. Murray Ch.J.L., Frenk J., Gakidou E. Measuring health inequality: challenges and new directions // Poverty, inequality, and health. An International perspective. D. Leon, G. Walt (eds.). Oxford: Oxford University Press, 2001. - https://doi.org/10.1093/acprof:oso/9780192631961.003.0010

5. Peltzman S. Mortality inequality // Journal of Economic Perspectives. - 2009. - Vol.23, № 4. P. 175-190. - https://doi.org/10.1257/jep.23.4.175

6. Shkolnikov V., Andreev E., and Begun A.Z. Gini coefficient as a life table function: Computation from discrete data, decomposition of differences and empirical examples // Demographic Research. - 2003. Vol. 8. Art. 11. - P. 305-358. - https://doi.org/0.4054/DemRes.2003.8.11 
7. Illsey R., Le Grand J. The measurement of inequality in health // Health and Economics. A.Williams (ed.) - London: Palgrave Macmillan, 1987. - P. 12-36. - https://doi.org/10.1007/978-1-34918800-0_2

8. Hanada K. A formula of Gini's concentration ratio and its application to life tables [Електронний pecypc] // Journal of Japan Statistical Society. - 1983. - Vol. 13, № 2. - P. 95-98. - Режим доступу: https://www.jstage.jst.go.jp/article/jjss1970/13/2/13_2_95/_pdf (дата звернення: 10.05.2019).

\section{REFERENCES}

1. Wilmoth, J.R. \& Horiuchi, S. (1999). Rectangularization revisited: Variability of age at death with human populations. Demography, 36(4), 475-495. - https://doi.org/10.2307/2648085

2. Kannisto, V. (2000). Measuring the Compression of Mortality. Demographic Research, Vol. 3, Art. 6. https://doi.org/10.4054/DemRes.200.3.6

3. Fries, J.F. (1980). Aging, natural death and the compression of morbidity. New England Journal of Medicine, 303, 130-135. - https://doi.org/10.1056/NEJM19800717303030

4. Murray, Ch.J.L., Frenk, J., \& Gakidou, E. (2001). Measuring health inequality: challenges and new directions. D. Leon, G. Walt (Eds.). Poverty, inequality, and health. An International perspective. Oxford: Oxford University Press. - https://doi.org/10.1093/acprof:oso/9780192631961.003.0010

5. Peltzman, S. (2009). Mortality inequality. Journal of Economic Perspectives, 4, 175-190. - https://doi. org/10.1257/jep.23.4.175

6. Shkolnikov, V., Andreev, E., \& Begun, A.Z. (2003). Gini coefficient as a life table function: Computation from discrete data, decomposition of differences and empirical examples. Demographic Research, 8(11),305-358. - https://doi.org/0.4054/DemRes.2003.8.11

7. Illsey, R. \& Le Grand, J. (1987). The measurement of inequality in health. A. Williams (Ed.). Health and Economics. London: Macmillan. - https://doi.org/10.1007/978-1-349-18800-0_2

8. Hanada, K. (1983). A formula of Gini's concentration ratio and its application to life tables. Journal of Japan Statistical Society, 13, 95-98. Retrieved from https://www.jstage.jst.go.jp/article/jjss1970/13/2/ 13_2_95/_pdf

Стаття надійшла до редакції 14.05.2019. 


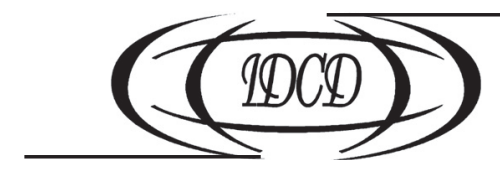

https://doi.org/10.15407/dse2019.02.065

УДК 316.42:330.46(477)

CLASSIFICATION: C87, E26

\section{О.А. ГРІШНОВА}

д-р екон. наук, проф.

Київський національний університет імені Тараса Шевченка

03022, Україна, м. Київ, вул. Васильківська 90-А

E-mail: grishnova@ukr.net

ORCID 0000-0002-4178-1662

\section{Ю.М. ХАРАЗІШВІЛІ}

д-р екон. наук, старш. наук. співроб.

Інститут економіки промисловості НАН України

03057, Україна, м. Київ, вул. Марії Капніст, 2

E-mail: yuri_mh@ukr.net

ORCID 0000-0002-3787-1323

\section{ДЕМОГРАФІЧНА БЕЗПЕКА УКРАЇНИ: ІНДИКАТОРИ, РІВЕНЬ, ЗАГРОЗИ}

Статтю присвячено ідентифікації рівня демографічної безпеки України за сучасною методологією, порівнянню його з інтегральними пороговими значеннями та визначенню найвпливовіших загроз у цій царині з позицій соціальної безпеки. Визначено робочий перелік індикаторів демографічної безпеки, який може змінюватись залежно від глибини та завдань дослідження. Проведено визначення меж безпечного демографічного розвитку з урахуванням досвіду економічно розвинених країн $Є C$, що уможливлює захист життєво важливих інтересів об'єкту безпеки. Відтак для кожного індикатора визначено вектор порогових значень: верхні та нижні оптимальне, порогове та критичне (для глибших досліджень) методом $t$-критерію через побудову функцій щільності ймовірності, обчислення статистичних характеристик (математичного очікування, середньоквадратичного відхилення та коефіцієнта асиметрії) з використанням таблиць Стьюдента та формалізованого опису вектора порогових значень за характерними типами розподілу (нормальний, логнормальний, експоненціальний). Ідентифікацію рівня демографічної безпеки удинаміці виконано шляхом інтегрального оцінювання за сучасною методологією, яка передбачає використання мультиплікативної форми інтегрального індексу, комбінованого методу нормування та динамічних вагових коефіцієнтів, визначених з використанням методів головних компонент та ковзної матриці. Інтегральна згортка проведена для індикаторів і порогових значень, що дає можсливість їхнього порівняння в одному масштабі для визначення загроз. Ідентифікація поточного стану демографічної безпеки України та визначення динаміки інтегрального індексу засвідчує його критичний рівень за всі роки незалежності України, що створює суттєву загрозу національній безпеці. Урезультаті окреслено найважливіші загрози та ранжовано їх за вагомістю впливу. Найсуттєвішими загрозами демографічної безпеки України за віддаленістю від рівня сталого розвиткує наднизький нетто-показник відтворення населення на одну жінку, високий рівень смертності населення загалом і смертності немовлят зокрема. 
Встановлено також, що найбільш впливовими факторами регулювання для рівня демографічної безпеки є коефіцієнт депопуляції та загальний коефіцієнт смертності населення.

Ключові слова: демографічна безпека, індикатори, порогові значення, інтегральний індекс, загрози.

\section{Е.А. Гришнова}

д-р экон. наук, проф.

Киевский национальный университет имени Тараса Шевченко

03022, Украина, г. Киев, ул. Васильковская, 90-А

E-mail: grishnova@ukr.net

ORCID 0000-0002-4178-1662

\section{Ю.М. Харазишвили}

д-р экон. наук, старш. науч. сотруд.

Институт экономики промышленности НАН Украины

03057, Украина, г. Киев, ул. Марии Капнист, 2

E-mail: yuri_mh@ukr.net

ORCID 0000-0002-3787-1323

\section{ДЕМОГРАФИЧЕСКАЯ БЕЗОПАСНОСТЬ УКРАИНЫ: ИНДИКАТОРЫ, УРОВЕНЬ, УГРОЗЫ}

Статья посвящена идентификации уровня демографической безопасности Украины по современной методологии, сравнению его с интегральными пороговыми значениями и определению самых влиятельных угроз в этой области с позиций социальной безопасности. Определен рабочий перечень индикаторов демографической безопасности, который может изменяться в зависимости от глубины и задач исследования. Определены границы безопасного демографического развития с учетом опыта экономически развитых стран ЕC, что делает возможной защиту жизненно важных интересов объекта безопасности. Для этого для каждого индикатора определен вектор пороговых значений: верхние и нижние оптимальное, пороговое и критическое (для более глубоких исследований) методом t-критерия путем построения функций плотности вероятности, вычисления статистических характеристик (математического ожидания, среднеквадратического отклонения и коэффициента асимметрии) с использованием таблии Стьюдента и формализованного описания вектора пороговых значений по характерным типам распределения (нормальный, логнормальный, экспоненциальный). Идентификация уровня демографической безопасности в динамике выполнена путем интегральной оценки по современной методологии, предусматривающей использование мультипликативной формы интегрального индекса, комбинированного метода нормирования и динамических весовых коэффициентов, определенных с использованием методов главных компонент и скользящей матрицы. Интегральная свертка проведена для индикаторов и пороговых значений, что дает возможность их сравнения в одном масштабе для определения угроз. Идентификация текущего состояния демографической безопасности Украины и определение динамики интегрального индекса показывает его критический уровень за все годы независимости Украины, что создает существенную угрозу национальной безопасности. В результате обозначены и ранжсрованы по значимости воздействия важнейшие угрозы. Наиболее существенными угрозами демографической безопасности Украины по удаленности от уровня устойчивого развития являются сверхнизкий нетто-показатель воспроизводства населения на одну женщину, высокий уровень смертности населения в целом и смертности младенцев в частности. Установлено также, что наиболее влиятельными регулирующими факторами для уровня демографической безопасности являются коэффициент депопуляции и общий коэффициент смертности населения.

Ключевые слова: демографическая безопасность, индикаторы, пороговые значения, интегральный индекс, угрозы.

\section{O.A. Grishnova}

Dr. Sc. (Economics), Prof.

Taras Shevchenko National University of Kyiv

03022, Ukraine, Kyiv, Vasylkivska Str., 90 A

E-mail: grishnova@ukr.net

ORCID 0000-0002-4178-1662 


\author{
Y.M. Kharazishvili \\ Dr. Sc. (Economics), SRF, Senior Research Associate \\ Institute of Industrial Economics \\ of the National Academy of Sciences of Ukraine \\ 03057, Ukraine, Kyiv, Marii Kapnist Str., 2 \\ E-mail: yuri_mh@ukr.net \\ ORCID 0000-0002-3787-1323
}

\title{
DEMOGRAPHIC SECURITY OF UKRAINE: INDICATORS, LEVEL, THREATS
}

The article aims to identify the level of demographic security in Ukraine according to modern methodology, by comparing it with the integral thresholds and identifying the most influential threats in this area from the standpoint of social security. The authors defined a working list of demographic safety indicators, which may vary depending on the depth and objectives of the study. The paper identified the boundaries for safe demographic development, taking into account the experience of economically developed EU member states, which makes it possible to protect the vital interests of the security object. Thus, for each indicator, the scholars defined a vector of threshold values, particularly: upper and lower optimal value, upper and lower threshold value, as well as upper and lower critical value (for more in-depth studies) by using the t-test through shaping the probability density functions, computing the statistical characteristics (mathematical expectation, mean squared error and the coefficient of skewness) while using Student tables and a formalised description of the threshold values' vector for the characteristic distribution types (normal, log-normal, exponential one). The research identified the changes in the demographic security level by means of integral estimation with the use of the modern methodology, which involves the use of the multiplicative form of the integral index, combined valuation method and dynamic weight coefficients determined using the 'main components' and the 'slip matrix' methods. The authors carried out the integral convolution both for indicators and for threshold values, which allows comparing them in one scale to identify threats. The results of identifying the current state of demographic security in Ukraine and defining the changes in the integral index confirm its critical level throughout all years of independent Ukraine, which poses a significant threat to national security. Therefore, the article outlined the most important threats and ranked them according to the weight of influence. According to the detachment from the sustainable development level the most significant threats to demographic security of Ukraine are the ultra low net reproduction rate of population on 1 stalk, the high mortality rate of the population in general and the mortality of infants in particular. It was also established that the most influential regulatory factors on the level of demographic security are: the coefficient of depopulation and the total mortality rate of the population.

Keywords: demographic security, indicators, threshold values, integral index, threats.

Постановка та актуальність проблеми. Тривале поглиблення демографічної кризи в Україні спонукає розглядати ситуацію з позицій демографічної безпеки. Адже негативні тенденції практично всіх складових демопроцесу - народжуваності, смертності, шлюбності, міграції, здоров’язбережувальній поведінці та ін. - ведуть до втрати здатності країни до самовідтворення населення у досягнутій якості й кількості. В інтересах держави і суспільства є формування такого типу відтворення, основні характерні риси якого - збереження кількісних і розвиток якісних характеристик населення, збільшення тривалості активного життя, прогресивна статево-вікова структура, оптимальні внутрішні і зовнішні міграційні процеси, зміцнення родинних цінностей та соціальної відповідальності за життя і здоров’я людей. Захист цих інтересів та створення умов для реалізації їх і складає сутність демографічної безпеки суспільства та держави.

Збереження та зміцнення демографічного потенціалу країни, подолання кризових демографічних процесів заявлено у статті 8 Закону України «Про основи національної безпеки України» серед основних напрямів державної політики. Важливість цієї проблеми засвідчує і розробка проекту закону «Про демографічну безпеку України» [1], а тривале його ігнорування вказує на байдужість влади до цих питань та недостатнє наукове обгрунтування їх вирішення. На жаль, новий Закон «Про на- 
ціональну безпеку України» (2018) має суттєвий перекіс у бік сфери безпеки і оборони 3 нехтуванням всіма іншими найважливішими сферами безпеки (економічна, соціальна, екологічна), які є першорядними, а у Законі принизливо віднесені до інших. Головною тезою нового Закону про національну безпеку України є забезпечення ефективного функціонування сектору безпеки і оборони, який названий автором основою системи забезпечення національної безпеки - насправді він є похідною від економічної та соціальної безпеки.

Аналіз останніх досліджень і публікацій. Нагальність і важливість демографічних проблем в Україні привертає значну увагу науковців. Передусім треба відзначити праці вчених Інституту демографії та соціальних досліджень ім. М.В. Птухи НАН України: О. Гладуна (O. Gladun) [2], Н. Левчук (N. Levchuk) [3], Е. Лібанової (E. Libanova) [4], H. Рингач (N. Rynhach) [5], B. Стешенко (V. Steshenko) [6] та ін. 3 позицій нацональної / соціальної безпеки ці проблеми розглядали I. Гнибіденко (I. Hnybidenko) [7], M. Дністрянський (M. Distryanskyi) [8] та ін. У статті [2] здійснено кількісну оцінку гіпотетичних демографічних втрат населення України від соціальних катастроф XX століття та їх впливу на загальну чисельність населення станом на початок 2013 року. У праці [3] виконано порівняльний аналіз динаміки календарної та когортної тривалості життя в Україні в історичній ретроспективі: за період 1850-2013 рр. та для когорт 1850-1923 рр. народження. У роботі Е. Лібанової [4] наведені оцінки основних демографічних тенденцій в Україні, їх порівняння із загальносвітовими трендами, прогноз подальшого розвитку та характеристика соціально-економічних наслідків. Стаття [6] присвячена взаємозв’язку понять «демографічний розвиток» і «людський розвиток», які розглянуто в рамках предметів відповідних наукових знань. У праці [8] наведено аналіз окремих індикаторів демографічної безпеки, узагальнено окреслені тенденції демографічного розвитку України впродовж тридцяти останніх років, що визначають характерні риси сучасної демографічної ситуації та запропоновані заходи щодо пом'якшення демографічної кризи.

У згаданих та інших працях здійснено аналіз деяких демографічних індикаторів, окреслено тенденції демографічного розвитку України, визначені характерні риси сучасної демографічної ситуації порівняно із загальносвітовими трендами, спрогнозовано подальший розвиток та охарактеризовано соціально-економічні наслідки, запропоновані очевидні заходи щодо пом'якшення демографічної кризи, головним із яких є суттєве економічне піднесення. Попри всю важливість виконаних досліджень, поза увагою залишилось визначення динаміки демографічної безпеки загалом, 3 урахуванням усіх важливих індикаторів, тобто кількісної оцінки рівня демографічної безпеки порівняно з інтегральними пороговими значеннями.

Значно менше робіт присвячено питанням оцінювання рівня демографічної безпеки та обгрунтування іiі індикаторів, лише одна (І. Цвігун, [9]) доведена до логічного завершення - розробки системи індикаторів демографічної безпеки та порогових значень основних показників, що характеризують загрози демографічній безпеці, побудови інтегрального індексу демографічної безпеки, його розрахунку за минулий і прогнозування на майбутній період.

Визнаючи суттєвий внесок роботи [9] у дослідження демографічної безпеки України, маємо, однак, зауважити певні невикористані резерви методики цих розрахунків. Вони стосуються, насамперед, задання одного гранично-критичного значення для кожного індикатора з наступним його нормуванням (замість визначення вектора порогових значень), нормування індикаторів-стимуляторів за лінійною функцією, а індикаторів-дестимуляторів за нелінійною функцією (рівняння гіперболи), що має наслідком «придушення» нормованих значень індикаторів, принципу побудови 
ваг для блоків показників, неможливості порівняння динаміки інтегрального індексу демографічної безпеки з інтегральними пороговими значеннями (бо вони не розраховані), як наслідок - суб’єктивна шкала оцінки інтегрального індексу демографічної безпеки та неточні висновки.

Мета цієї роботи - ідентифікація рівня демографічної безпеки України за сучасною методологією, порівняння його з інтегральними пороговими значеннями та визначення найвпливовіших загроз у цій царині з позицій соціальної безпеки.

Наукова новизна. У роботі вперше обгрунтовано визначення вектора порогових значень індикаторів демографічної безпеки методом $t$-критерію через побудову функцій щільності ймовірності, обчислення статистичних характеристик (математичного очікування, середньоквадратичного відхилення та коефіцієнта асиметріі) з використанням таблиць Стьюдента та формалізованого опису вектора порогових значень за характерними типами розподілу (нормальний, логнормальний, експоненціальний). Визначено динаміку інтегрального індексу демографічної безпеки за сучасною методологією оцінювання з використанням модифікованого методу нормування та динамічних вагових коефіцієнтів у порівнянні з інтегральними пороговими значеннями, що саме й дає змогу ідентифікувати стан демографічної безпеки та визначити вплив загроз.

Інформаційна база. У роботі використано масив статистичних індикаторів (із національних - Держстат України, та міжнародних джерел - Дослідження глобального тягаря хвороб (2016) Global Burden of Disease Study (2016) [10]); Всесвітня книга фактів (2017), Центральне розвідувальне управління (The World Factbook (2017), Central Intelligence Agency [11]); Офіційний сайт Євростату «Демографія і міграція»(2017), The Official Site of Eurostat (2017), «Demography and Migration» [12]), що характеризують рівень і структуру демографічної безпеки за останні роки.

Основні країни, дані шодо яких використано для визначення вектора порогових значень: Франція, Велика Британія, Швеція, Фінляндія, Іспанія, Данія, РФ, Словакія, Польща, Чехія, Італія, Португалія, Німеччина, Канада, Люксембург, Нідерланди, Норвегія, Австрія, Ірландія, США, Китай (у різних комбінаціях для різних індикаторів). Для конкретних індикаторів обрано країни, що мають найкращі значення відповідних індикаторів і можуть бути перспективним взірцем для України. Вибір однакового переліку країн та однакового періоду часу є бажаним, але не завжди можливим. Аналогічну думку висловлює Е.М. Лібанова: «...Під час напрацювання гіпотези треба враховувати не лише наявні тенденції своєї країни, а й параметри їх розвитку в інших країнах, передовсім тих, які для України можуть слугувати еталоном» $[4$, c. 10]. Визначення вектору порогових значень аналогічне конструюванню гіпотетичної країни з найвищим рівнем демографічної безпеки за всіма індикаторами.

Проміжок часу, для якого обрались відповідні дані - 2015-2016 рр., іноді взято прогнозні дані Євростату 2015-2020 рр. Головне призначення вектора порогових значень - ідентифікація рівня демографічної безпеки, визначення цілей подальшого розвитку та можливість застосування методології стратегування сталого розвитку 3 позицій безпеки [13]. Вектор порогових значень потрібно переглядати приблизно через 3-5 років, а краще - застосовувати динамічні порогові значення як і динамічні вагові коефіцієнти.

Методи дослідження. Дослідження складається з трьох етапів, серед яких головним є моделювання. У ході дослідження застосовано: статистичні характеристики варіаційних рядів та розподілів для аналізу специфіки розподілу демографічних індикаторів і оцінки ступеня наближення структурних характеристик даного процесу в Україні до європейських аналогів шляхом визначення вектора порогових значень; 
методи аналізу взаємозв’язку для розрахунку коефіцієнтів еластичності і оцінки впливу демографічних індикаторів на інтегральний індекс демографічної безпеки на матеріалах України та інших європейських країн.

На першому етапі здійснюється формування динаміки індикаторів та визначення меж безпечного існування через побудову функцій щільності ймовірності та розрахунок статистичних характеристик: математичного очікування, середньоквадратичного відхилення та коефіцієнта асиметрії для розрахунку вектора порогових значень кожного індикатора. З усього розмаїття видів функцій щільності ймовірності виділено типи з найбільш характерним та наближеним до нього законом розподілу: нормальним, логнормальним та експоненціальним, для яких запропоновано формули обрахунку вектора порогових значень [13, с. 66-72].

На другому етапі здійснюється інтегральна згортка індикаторів і порогових значень із застосуванням мультиплікативної форми інтегрального індексу:

$$
I_{t}=\prod_{i=1}^{n} z_{i, t}^{a_{i}} ; \quad \sum a_{i}=1 ; \quad a_{i} \geq 0
$$

де $I$ - інтегральний індекс; $z$ - нормований індикатор; $a$ - ваговий коефіцієнт.

Також застосовано модифікований метод нормування:

$$
S: z_{i}=\frac{x_{i}}{k_{\text {норм }}}, \quad D: z_{i}=\frac{k_{\text {норм }}-x_{i}}{k_{\text {норм }}}, \quad k_{\text {норм }}>x_{\max },
$$

де $x$ - значення індикатора; $k_{\text {норм }}$ - нормувальний коефіцієнт (для стимуляторів дорівнює максимальному значенню з ряду індикаторів і порогових значень; для дестимуляторів обирається більшим за максимальне значення з того ж ряду на 5-10 \%).

Використано і метод динамічних вагових коефіцієнтів з застосуванням методів головних компонент:

$$
C_{i} \times D_{i}=\left(\begin{array}{l}
d_{1} c_{11}+d_{2} c_{12}+\ldots+d_{j} c_{1 j} \\
d_{1} c_{21}+d_{2} c_{22}+\ldots+d_{j} c_{2 j} \\
\ldots \ldots \ldots \ldots \ldots \ldots \ldots \ldots \ldots \ldots \ldots \\
d_{1} c_{j 1}+d_{2} c_{j 2}+\ldots+d_{j} c_{j j}
\end{array}\right)=\left(\begin{array}{l}
w_{1} \\
w_{2} \\
\ldots \\
w_{j}
\end{array}\right), \quad a_{i}=\frac{w_{i}}{\sum w_{i}},
$$

де $C$ - матриця абсолютних величин факторних навантажень; $D$ - вектор-матриця дисперсій; i, з рештою, методу «ковзної матриці» [13, с. 79-81], який полягає у послідовному зсуві матриці мінімально необхідного розміру вздовж періоду часу та визначенні вагових коефіцієнтів за даний часовий період. Причому мінімально необхідний розмір матриці визначається з умови рівності кількості індикаторів (кількості головних компонент) кількості додатних власних значень цієї матриці.

На третьому етапі розраховуються коефіцієнти еластичності для виявлення вагомості впливу окремих індикаторів на інтегральний індекс:

$$
E=\frac{\Delta y}{\Delta x} \cdot \frac{x}{y}
$$

де $x$ - будь-якій індикатор демографічної безпеки; $y$ - інтегральний показник демографічної безпеки; $\Delta x$ - приріст відповідного індикатора; $\Delta y-$ приріст інтегрального показника. 
Виклад основного матеріалу дослідження. Демографічна безпека - стан захищеності основних життєво важливих демовідновлювальних процесів від реальних та потенційних загроз. Мета демографічної безпеки - створення умов, достатніх для попередження і нейтралізації демографічних загроз. У структурі соціальної безпеки $[14$, c. 160] цей складник ми характеризуємо такими індикаторами:

- середня очікувана тривалість життя при народженні, років $\left(S^{1}\right)$;

- умовний коефіцієнт депопуляції (відношення числа померлих до числа народжених, $D$ );

- загальний коефіцієнт смертності населення (число померлих на 1000 осіб наявного населення, $D)$;

- смертність немовлят (число дітей, померлих у віці до 1 року, на 1000 народжених живими, $D$ );

- сумарний коефіцієнт народжуваності, дітей на одну жинку репродуктивного віку $S$ );

- нетто-показник відтворення населення на 1 жінку (середнє число дівчаток, яких жінка народила за весь плідний період ії життя і які дожили до віку, в якому була жінка при народженні цих дівчаток, $S)$.

Середня очікувана тривалість життя при народженні - найважливіший індикатор демографічної безпеки, підсумковий показник якості життя й соціально-економічних можливостей в країні. За даними американського інституту Дослідження глобального тягаря хвороб (2016) [10], з 1990 р. в Україні зросла тривалість життя та суттєво зменшилась дитяча смертність, але розвинуті країни тим часом досягли суттєвих успіхів у цьому напрямі (рис. 1). Наразі Україна посідає 149 місце зі 198 країн світу і 42 місце з 44 країн Європи за очікуваною тривалістю життя. Очікувана тривалість життя - складний системний індикатор, що залежить від багатьох факторів рівня та якості життя і змінюється дуже повільно через високу інерційність процесу.

Вектор порогових значень для цього індикатора розраховано нами за методом $t$-критерію згідно з визначеними типами розподілу функцій щільності ймовірності індикаторів [13].
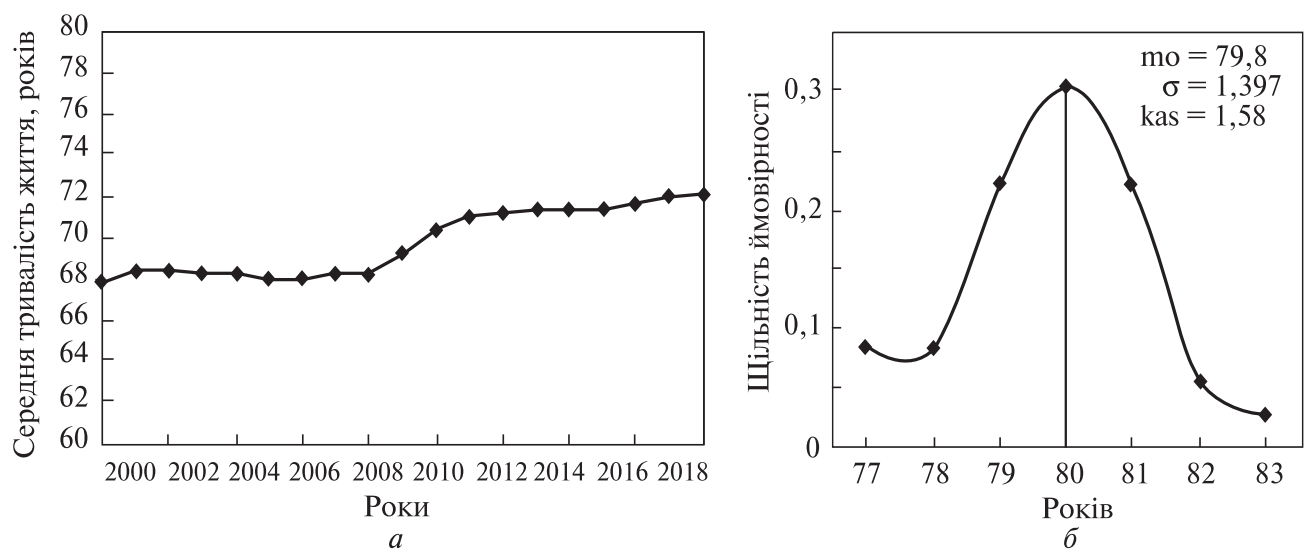

Рис. 1. Динаміка середньої тривалості життя в Україні (a) та щільність ймовірності середньої тривалості життя економічно розвинених країн (б)

Джерело: $a$ - Держстат України (прогноз, 2018); б - розраховано авторами за даними [10].

${ }^{1} S$ - стимулятор, збільшення якого бажано; $D$ - дестимулятор, зменшення якого бажано. 
Коефіцієнт депопуляції. Говорячи про депопуляцію, маємо на увазі саме негативну величину природного приросту населення, тобто перевищення числа померлих над числом народжених. Сучасна ситуація в Україні сприяє зменшенню чисельності населення за рахунок як природних, так і зовнішніх причин (бойові дії на Донбасі, еміграція тощо) (рис. 2, а).

Для поліпшення демографічної ситуації зазвичай застосовується система адміністративних, пропагандистських, економічних, медичних та інших заходів, спрямованих на зміну природного руху населення - підняття рівня народжуваності та зменшення рівня смертності. Одним із впливових важелів активізації народжуваності є зростання рівня життя (й, відповідно, оптимістичні очікування) населення, зниження якого в Україні чітко корелює зі зростанням коефіцієнта депопуляції (рис. 2).

Наслідком є ускладнення демографічної ситуації через відтік (еміграцію) працездатного населення за межі країни у пошуках вищеоплачуваної роботи і кращої долі.
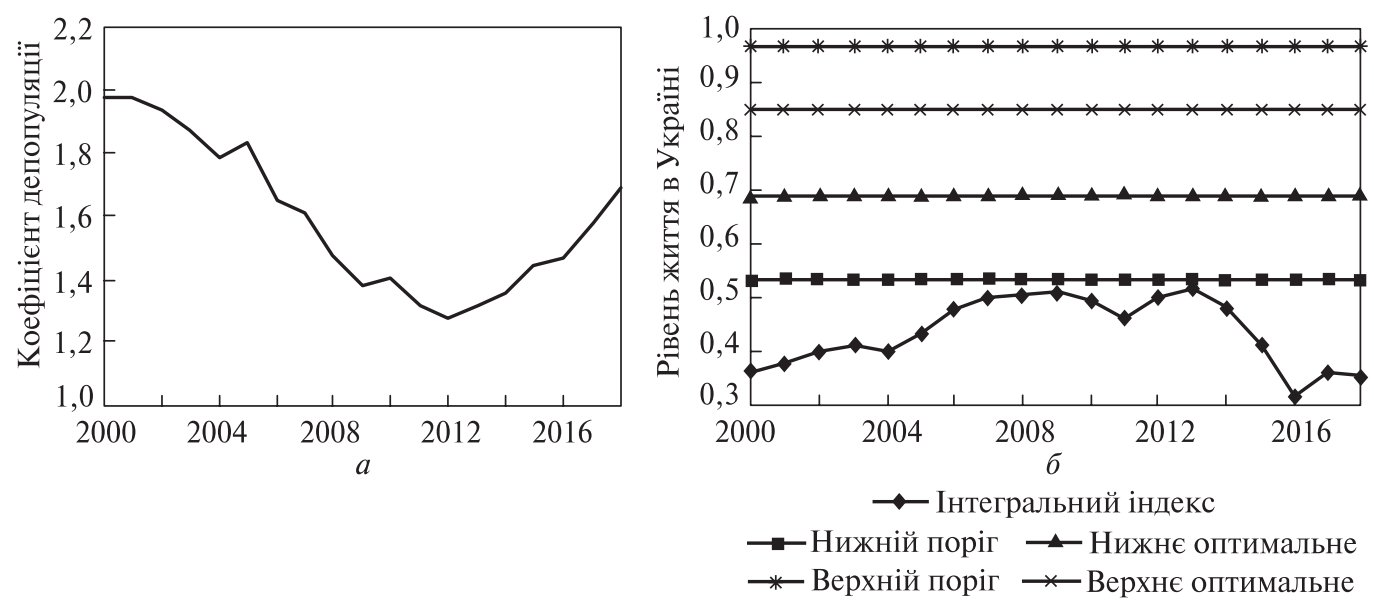

Рис. 2. Динаміка коефіцієнта депопуляції (a) та рівня життя (б) в Україні

Джерело: $a$ - Держстат України (прогноз, 2018); 6 - розраховано авторами у роботі [14].
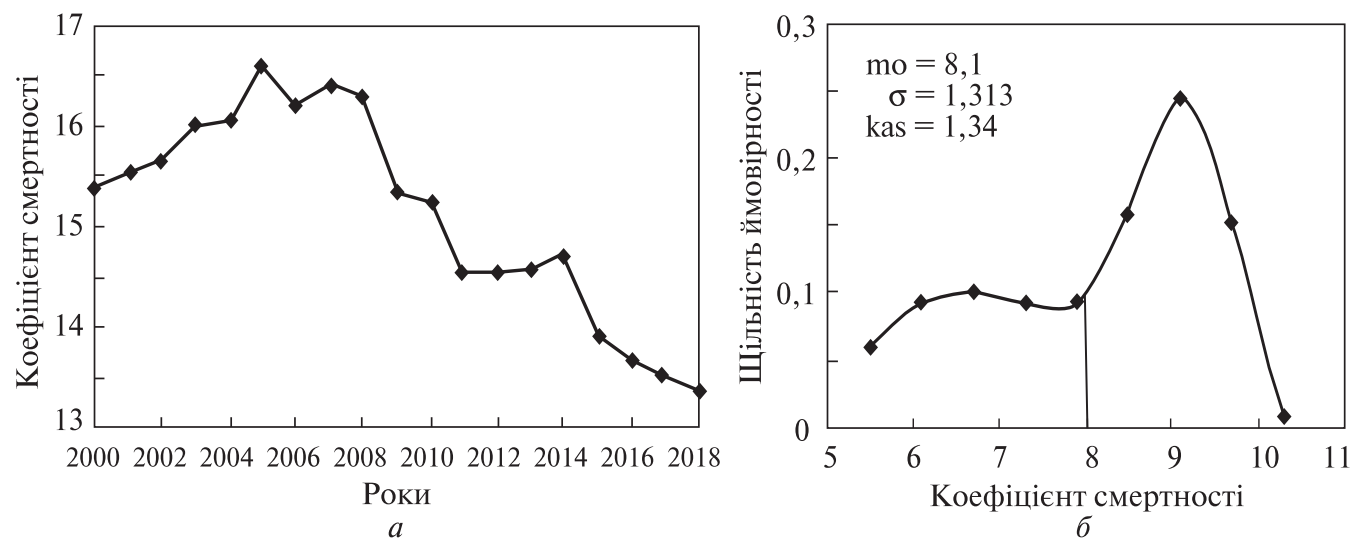

Рис. 3. Динаміка коефіцієнта смертності в Україні (a) та щільність ймовірності коефіцієнта смертності економічно розвинених країн (б)

Джерело: а - Держстат України (прогноз, 2018); б - розраховано авторами за даними [11]. 
Водночас явище депопуляції не рідкісне у Європі: у третині європейських держав на сьогодні фіксують природний убуток населення. 3 огляду на це, вектор порогових значень цього індикатора ми визначали, орієнтуючись на 10 європейських країн 3 кращою ситуацією щодо природного руху населення.

Загальний коефіцієнт смертності населення в Україні постійно зменшується, що $є$ позитивним моментом, але все ж таки суттєво відстає від рівня економічно розвинених країн (рис. 3).

У загальній структурі причин смертності основне місце посідає смертність від серцево-судинних захворювань, показник якої є одним із найвищих у світі. Використовуючи статистичні дані загального коефіцієнта смертності по країнах ЄС та світу [11] (обрані країни з коефіцієнтом смертності $\leqslant 10$ ), можна розрахувати вектор порогових значень за методом $t$-критерію.

Смертність немовлят. Показники смертності дітей є принципово важливими демографічними й соціальними індикаторами. Вони віддзеркалюють загальну якість життя населення, інтегруючи результати екологічних, економічних, освітніх, політичних, медичних та інших здобутків чи проблем країни. Незважаючи на позитивні тенденції в Україні (рис. 4, a), порівняно з європейськими країнами рівень дитячої смертності ще високий - майже вісім смертей на тисячу народжених живими в Україні, проти 3,76 у СС (рис. 4, б). Вектор порогових значень розраховано за методом $t$-критерію на основі статистичних даних розвинених країн.

Сумарний коефіцієнт народжуваності. За сумарним коефіцієнтом народжуваності Україна з 2000 р. мала найвище досягнення у 2012 р. - 1,531 дітей на одну жінку репродуктивного віку, а у 2017 р. - 1,374 (прогноз на 2018 р. - 1,3) (рис. 5, a) та серед 22 країн ЄС поряд із Іспанією, Португалією, Польщею, Італією та Грецією займає останні місця. Лідерами за сумарним коефіцієнтом народжуваності 1,7-2,0 є Франція, Швеція, Велика Британія, Ірландія, Бельгія, Норвегія та ін. Середнє значення сумарного коефіцієнта народжуваності (для країн СС, де він >1,3) дорівнює 1,634 (рис. 5, б). Вектор порогових значень розраховується методом t-критерію з урахуванням статистичних даних розвинених країн $\mathrm{EC}$.
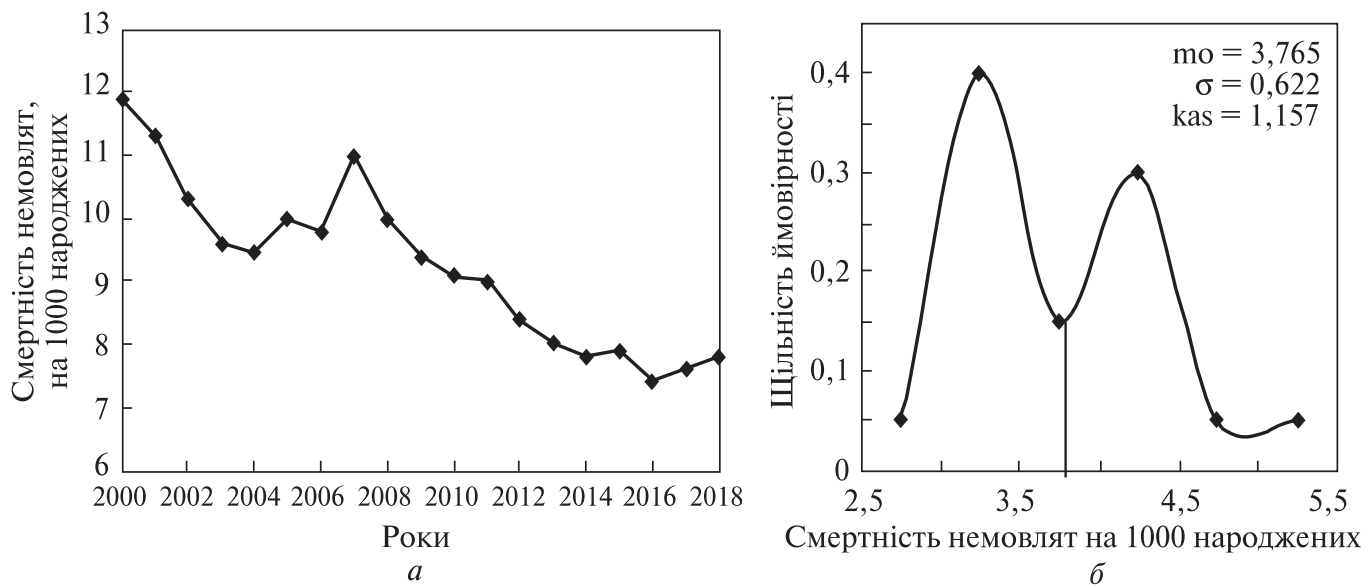

Рис. 4. Коефіцієнт смертності немовлят в Україні (a) і щільність ймовірності коефіцієнта смертності немовлят економічно розвинених країн (б)

Джерело: а - за даними Держстату України; б - розраховано авторами за даними [12]. 
Нетто-показник відтворення населення на одну жінку характеризує ступінь заміщення покоління матерів поколінням дочок. Якщо він менший за одиницю - кожне наступне покоління матерів менше від попереднього.

В Україні цей індикатор за 2000-2018 рр. ніколи не піднімався вище 0,73, а за останні три роки досяг критичного значення: 0,656 у 2017 та 0,617 у 2018 (за прогнозом) (рис. $6, a)$. Статистичні дані ООН [16] для 10 економічно розвинених країн для цього індикатора за періоди 2010-2015 та 2015-2020 свідчать про фактичне звужене відтворення як загальну тенденцію (рис. 6, б).

Необхідно зазначити, що використаний нами перелік індикаторів демографічної безпеки не є абсолютним, виражає бачення авторів та може змінюватись залежно від завдань і глибини дослідження. Так само треба періодично переглядати вектор порогових значень залежно від рівня розвитку країни та світу. 3 урахуванням
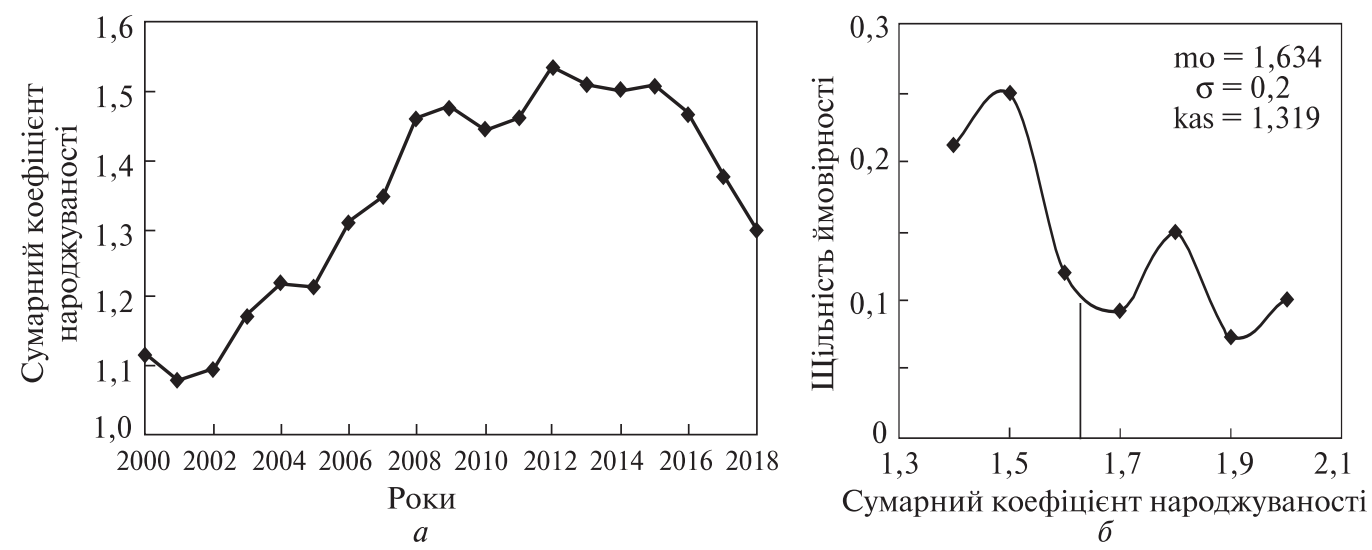

Рис. 5. Динаміка сумарного коефіцієнта народжуваності в Україні (a) та щільність ймовірності сумарного коефіцієнта народжуваності економічно розвинених країн $\mathrm{EC}(>1,3)($ )

Джерело: $a$ - за даними Держстату України; 6 - розраховано авторами за даними [15].
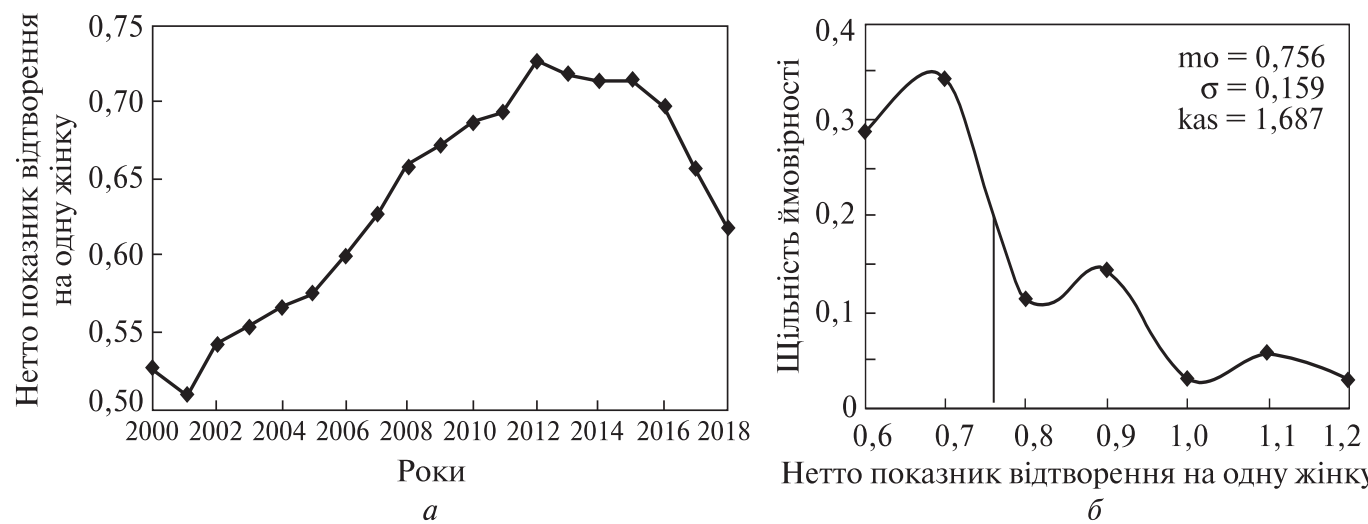

Нетто показник відтворення на одну жінку $\sigma$

Рис. 6. Динаміка нетто-показника відтворення населення на одну жінку в Україні ( $a$ ) та щільність ймовірності нетто-показника відтворення населення на одну жінку для економічно розвинених країн ЕС (б)

Джерело: а - за даними Держстату України; б - розраховано авторами за даними ООН [16]. 
різноспрямованих динамічних змін індикаторів необхідно застосовувати інтегральні індекси оцінки, які описували б зміну рівня об'єкту безпеки відносно інтегральних порогових значень. Порівняння інтегрального рівня демографічної безпеки з інтегральними пороговими значеннями є основним завданням нашого аналізу, оскільки визначає поточний стан об’єкту безпеки у всій його багатогранності.

Загалом методологія економічної безпекометрії в частині ідентифікації об’єкта безпеки повинна охоплювати вирішення таких завдань [13]: визначення структури об’єкту безпеки; формування переліку складових та індикаторів об'єкту безпеки; вибір форми інтегрального індексу; вибір методу нормування; наукове обгрунтування динамічних вагових коефіцієнтів; наукове обгрунтування вектору порогових значень.

З урахуванням виявлених недоліків наявних підходів у роботі [17] запропоновано методологію інтегрального оцінювання рівня економічної безпеки (держави, регіону, підприємства), яка використовує: форму інтегрального індексу - мультиплікативну; метод нормування - комбінований; вагові коефіцієнти - динамічні на основі застосування методів головних компонент і ковзної матриці.

Без знання границь безпечних умов життєдіяльності неможливий захист життєво важливих інтересів об’єктів безпеки. Саме тому для кожного індикатора необхідно визначити вектор нижніх та верхніх порогових значень: критичного, порогового, оптимального.

Зазвичай достатньо порогових та оптимальних значень, а для глибших досліджень доцільно розширити вектор порогових значень додаванням ще двох критичних значень, як це запропоновано у Методиці МЕРТ (2007) [18]: нижнє критичне $\left(x^{\mu}{ }_{k p}\right)$, верхнє критичне $\left(x^{6}{ }_{\kappa p}\right)$, порушення яких може призвести до руйнування системи.

Аналіз індикаторів демографічної безпеки України в частині обгрунтування вектора порогових значень виявив характерні типи розподілу (нормальний, логнормальний та експоненціальний), для яких визначено формалізований опис вектора порогових значень [13] за методом $t$-критерію [19] (табл. 1).

Наведемо приклади розрахунку порогових значень для характерних типів розподілу (табл. 2): нормальний (рис. 1, б); логнормальний (рис. 3, б); експоненціальний (рис. 6, б).

Таблиия 1. Вектор порогових значень індикаторів демографічної безпеки України

\begin{tabular}{|l|c|c|c|c|c|c|}
\hline \multicolumn{1}{|c|}{ Індикатори } & $\begin{array}{c}\text { Нижній } \\
\text { поріг }\end{array}$ & $\begin{array}{c}\text { Нижнє } \\
\text { оптим. }\end{array}$ & $\begin{array}{c}\text { Верхнє } \\
\text { оптим. }\end{array}$ & $\begin{array}{c}\text { Верхній } \\
\text { поріг }\end{array}$ & $\begin{array}{c}\text { Норму- } \\
\text { вальний } \\
\text { коефіцієнт }\end{array}$ & $\begin{array}{c}\text { Україна, } \\
\mathbf{2 0 1 8}\end{array}$ \\
\hline $\begin{array}{l}\text { Середня очікувана тривалість життя при } \\
\text { народженні, років }(S)\end{array}$ & 76 & 78,4 & 81,2 & 83,6 & 85 & 72,17 \\
\hline Коефіцієнт депопуляціі $(D)$ & 1,1 & 1,05 & 0,95 & 0,9 & 2,1 & 1,53 \\
\hline $\begin{array}{l}\text { Загальний коефіцієнт смертності населен- } \\
\text { ня }(D)\end{array}$ & 11,5 & 9,4 & 7,0 & 5,6 & 17 & 13,35 \\
\hline Смертність немовлят $(D)$ & 5,53 & 4,4 & 3,34 & 2,6 & 13 & 7,81 \\
\hline Сумарний коефіцієнт народжуваності $(S)$ & 1,483 & 1,634 & 1,834 & 2,16 & 2,2 & 1,3 \\
\hline $\begin{array}{l}\text { Нетто-показник відтворення населення на } \\
\text { одну жінку }(S)\end{array}$ & 0,662 & 0,756 & 0,915 & 1,188 & 1,25 & 0,617 \\
\hline Інтегральні порогові значення & 0,5459 & 0,6229 & 0,7143 & 0,7968 & & 0,4045 \\
\hline
\end{tabular}

Джерело: модельні розрахунки авторів [10-12, 15-16]. 
Таблиия 2. Приклади розрахунків вектору порогових значень*

\begin{tabular}{|l|c|c|c|c|}
\hline \multicolumn{1}{|c|}{ Тип розподілу } & $\begin{array}{c}\text { Нижнє } \\
\text { порогове }\end{array}$ & $\begin{array}{c}\text { Нижнє } \\
\text { оптимальне }\end{array}$ & $\begin{array}{c}\text { Верхнє } \\
\text { оптимальне }\end{array}$ & $\begin{array}{c}\text { Верхнє } \\
\text { порогове }\end{array}$ \\
\hline Нормальний $t=2,72$ & $\mu-t \cdot \sigma$ & $\mu-\sigma$ & $\mu+\sigma$ & $\mu+t \cdot \sigma$ \\
& 76,0 & 78,4 & 81,2 & 83,6 \\
\hline Логнормальний $t=2,539$ & $\mu-t \cdot \sigma / k_{a s}$ & $\mu-\sigma / k_{a s}$ & $\mu+\sigma$ & $\mu+t \cdot \sigma$ \\
& 5,6 & 7,1 & 9,4 & 11,5 \\
\hline Експоненціальний $t=2,753$ & $\mu-\sigma / k_{a s}$ & $\mu$ & $\mu+\sigma$ & $\mu+t \cdot \sigma$ \\
& 18,3 & 26,6 & 47,0 & 83,0 \\
\hline
\end{tabular}

Джерело: модельні розрахунки авторів [10-12, 15-16].

* Для індикаторів-дестимуляторів порядок порогових значень змінюється навпаки; $t$ - із таблиць $t$-розподілу Стьюдента.

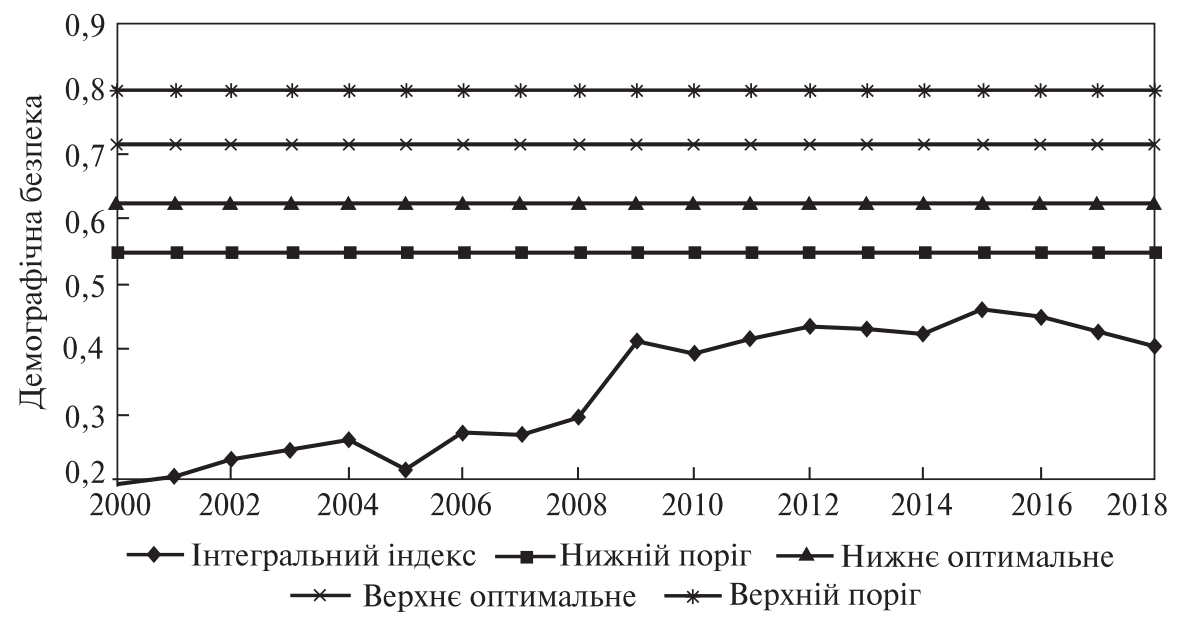

Рис. 7. Динаміка інтегрального індексу демографічної безпеки України

Джерело: розрахунки авторів.

У процесі дослідження можуть бути виявлені й інші характерні типи розподілу, як, наприклад, на рис. 4, б; 5, б; 7, б. Вельми правдоподібно, що вони можуть бути віднесені до логнормального (рис. 4, б; 5, б) або до експоненціального (рис. 7, б) типу розподілу.

Пара оптимальних значень утворюють «гомеостатичне плато», у межах якого існує від'ємний зворотній зв'язок і створюються найкращі умови існування й розвитку системи, а порушення критичних значень може призвести навіть до ії руйнування. Інтегральна згортка проводиться як для індикаторів об'єкту безпеки, так і для їхніх порогових значень, що дає змогу саме ідентифікувати рівень безпеки.

Отже, визначення порогових значень досить тісно пов'язане з поняттям динамічної стійкості системи та її складників, або з механізмом гомеостазу. Без такого порівняння будемо мати лише динаміку інтегральних індексів, які визначатимуть ix збільшення / зменшення в певні періоди, що може призвести до помилкового висновку щодо максимізації інтегрального індексу. Одночасне нормування 
індикаторів та їхніх порогових значень за єдиним нормувальним коефіцієнтом дає змогу в одному масштабі порівнювати динаміку інтегрального індексу з інтегральними пороговими значеннями, тобто ідентифікувати рівень демографічної безпеки (рис. 7), який засвідчує критичний рівень безпеки в Україні - значення інтегрального індексу нижче від нижнього порогового. Така ситуація обумовлена вкрай незадовільним рівнем більшості демографічних індикаторів.

Таким чином, визначення інтегральних індексів та їх порівняння з інтегральними пороговими значеннями переводить поняття «розвиток» у поняття «безпека».

Як видно з рис. 7, значення інтегрального індексу демографічної безпеки населення України у 2000-2018 рр. постійно знаходиться у критичній зоні - нижче нижнього порогового значення, але має ознаки відносної стабільності за останні 10 років з негативною динамікою за останні три роки. Порівняння динаміки індикаторів демографічної безпеки з пороговими значеннями (табл. 1) засвідчує, що всі шість індикаторів знаходяться у критичній зоні (нижче від нижнього порогу).

Для визначення вагомості впливу загроз можемо за формулою (4) обчислити коефіцієнти еластичності ( $E$ ) кожного індикатора (табл. 2), які визначають: на скільки відсотків змініться вихідна величина у (в нашому випадку - інтегральний показник демографічної безпеки) у разі зміни на 1 \% вхідної величини ( $x$ ) (табл. 3 ).

За результатами розрахунків визначаємо найвпливовіші індикатори -загрози демографічній безпеці (за пріоритетом впливу):

1) коефіцієнт депопуляції;

2) загальний коефіцієнт смертності населення;

3) середня очікувана тривалість життя при народженні.

Зміна цих індикаторів дуже сильно впливає на демографічну безпеку, тож вони потребують особливої уваги у процесі реформ.

Найважливіші загрози соціальній безпеці України в цьому контексті показують такі індикатори (за віддаленістю від межі сталого розвитку - середнього оптимального значення вектору порогових значень):

1) нетто-показник відтворення населення на одну жінку;

2) загальний коефіцієнт смертності населення;

3) смертність немовлят.

Таблиця 3. Коефіцієнти еластичності індикаторів демографічної безпеки

\begin{tabular}{|l|c|}
\hline \multicolumn{1}{|c|}{ Індикатори } & $E$ \\
\hline 1. Середня очікувана тривалість життя при народженні, років $(S)$ & 0,1799 \\
\hline 2. Коефіцієнт депопуляції, число померлих до числа народжених $(D)$ & $-0,753$ \\
\hline $\begin{array}{l}\text { 3. Загальний коефіцієнт смертності населення (число померлих на } 1000 \text { осіб } \\
\text { наявного населення), }(D)\end{array}$ & $-0,6196$ \\
\hline $\begin{array}{l}\text { 4. Смертність немовлят (число дітей, померлих у віці до 1 року, } \\
\text { на } 1000 \text { народжених живими), }(D)\end{array}$ & $-0,1711$ \\
\hline $\begin{array}{l}\text { 5. Сумарний коефіцієнт народжуваності, дітей на одну жинку } \\
\text { репродуктивного віку }(S)\end{array}$ & 0,1791 \\
\hline 6. Нетто-показник відтворення населення на одну жінку $(S)$ & 0,1796 \\
\hline
\end{tabular}

Джерело: розрахунки авторів. 
Тобто вкрай необхідно змінити з негативної на позитивну динаміку цих індикаторів, і це стане найкращою та - що важливо - об’єктивною ознакою виходу 3 демографічної кризи. Співвідношення фактичних значень інтегральних індексів 3 їхніми стратегічними значеннями для забезпечення сталого розвитку буде визначати дієвість політики забезпечення демографічної безпеки.

Висновки. Визначення переліку індикаторів рівня демографічної безпеки України та обгрунтування векторів порогових значень індикаторів із урахуванням досягнень економічно розвинених країн ЄС дало можливість кількісно і якісно ідентифікувати поточний стан демографічної безпеки.

Ідентифікація поточного стану демографічної безпеки України, виконана за сучасною методологією інтегрального оцінювання, визначення динаміки інтегрального індексу засвідчують його критичний рівень за всі роки незалежності України, що створює суттєву загрозу національній безпеці.

Наше дослідження унаочнює диспропорційність розвитку індикаторів демографічної безпеки та визначає перелік найважливіших загроз. Усі шість індикаторів перебувають у критичній зоні (нижче від нижнього порогу). Найсуттєвішими загрозами демографічній безпеці (за віддаленістю від рівня сталого розвитку) є: наднизький нетто-показник відтворення населення на одну жінку, високий рівень смертності населення загалом і немовлят зокрема.

Установлено, що найвпливовішими факторами регулювання рівня демографічної безпеки є: коефіцієнт депопуляції та загальний коефіцієнт смертності населення, вагомість впливу загроз розраховано як коефіцієнти еластичності кожного індикатора та їх ранжування.

Використання отриманих нами результатів для визначення пріоритетів соціально-демографічної політики держави, а також застосування запропонованої методики для моніторингу ситуації, забезпечить об'єктивне наукове обгрунтування напрямів досягнення демографічної безпеки у контексті соціальної безпеки України.

\section{ЛІТЕРАТУРА}

1. Про демографічну безпеку України: Закон України (проект від 15.10.2003 № 4269) [Електронний ресурс]. - Режим доступу: http://w1.c1.rada.gov.ua/pls/zweb2/webproc4_2?id=\&pf3516= $4269 \& \mathrm{skl}=5$ (дата звернення 15.03.2019).

2. Гладун О.М. Оцінка гіпотетичних втрат населення України за період 1897-2012 pp. // Демографія та соціальна економіка. - 2013. - № 2 (20). - C. 147-155. - https://doi.org/10/15407/ dse2013.02.147

3. Левчук Н.М. Календарна й когортна тривалість життя в Україні: особливості динаміки у довготривалій ретроспективі // Демографія та соціальна економіка. - 2016. - № 1 (26). C. 80-92. - https://doi.org/10/15407/dse2016.01.080

4. Либанова Э.М. Демографические сдвиги в контексте социального развития // Демографія та соціальна економіка, - 2014. - № 1 (21). - С. 9-23.- https://doi.org/10/15407/dse2014.01.009

5. Рингач $H$. Мінімізація демографічних загроз як необхідний компонент політики забезпечення національної безпеки України // Ефективність державного управління. - 2008. - Вип. 14/15. - C. $140-145$.

6. Стешенко В.С. Зміст понять «демографічний розвиток» $\mathrm{i}$ «людський розвиток»: род тотожності та відмінності // Демографія та соціальна економіка. - 2013. - № 1(19). - С. 5-16. - https://doi. org/10/15407/dse2013.01.005

7. Гнибіденко I. Демографічні аспекти національної безпеки держави // Україна: аспекти праці. - 2007. - № 5. - С. 11-18.

8. Дністрянський М. Демографічна криза в Україні як проблема національної безпеки [Електронний ресурс]. - Режим доступу: http://bintel.com.ua/uk/article/09-22-demograph/ (дата звернення 15.03.2019). 
9. Цвігун I.А. Демографічна безпека України та напрями ії регулювання. - Кам'янець-Подільський: Видавець ПП Зволейко Д.Г., 2013. - 400 с.

10. Global Burden of Disease Study 2016 (GDB 2016) Data Resources [Електронний ресурс]. - Режим доступу: http://ghdx.healthdata.org/gbd-2016 (дата звернення 15.03.2019).

11. The World Factbook (2017). Central Intelligence Agency [Електронний ресурс]. - Режим доступу: https://www.cia.gov/LIBRARY/publications/the-world-factbook/rankorder/2066rank.html (дата звернення 15.03.2019).

12. The Official Site of Eurostat (2017), «Demography and Migration», [Електронний ресурс]. - Режим доступу: http://ec.europa.eu/eurostat/data/database (дата звернення: 15.05.2017).

13. Харазішвілі Ю.М. Системна безпека сталого розвитку: інструментарій оцінки, резерви та стратегічні сценарії реалізації / НАН України, Ін-т економіки пром-сті. - Київ, 2019. - 304 с.

14. Харазішвілі Ю.М., Грішнова О.А. Якість життя в системі соціальної безпеки України: індикатори, рівень, загрози // Економіка України. - 2018. - № 11-12. - С. 157-171.

15. Статистичний щорічник України за 2017 р. Державна служба статистики України. За редакцією I.C. Вернера. - 2018. - 541 c.

16. Unated nations data retrieval system. [Електронний ресурс]. - Режим доступу: http://data.un.org/ Data.aspx?d=PopDiv\&f=variableID\%3A48 ( дата звернення 15.05.2019).

17. Харазішвілі Ю.М., Дронь С.В. Проблеми інтегрального оцінювання рівня економічної безпеки держави // Банківська справа. - 2015. - № 1 (133). - С. 3-21.

18. Методика розрахунку рівня економічної безпеки України, затверджена наказом Мінекономіки України від 02.03.2007 № 60 [Електронний ресурс]. - Режим доступу: http://me.kmu.gov.ua/control/uk/publish/article? art_id (дата звернення 15.05.2019).

19. Паніотто В.І. Максименко В.С., Марченко Н.М. Статистичний аналіз соціологічних даних. - Київ: КМ Академія, 2004. - 269 с.

\section{REFERENCES}

1. Zakon Ukrayiny «Pro demografichnu bezpeku Ukrayiny» (proekt vid 15.10.2003 № 4269) [The Law of Ukraine «On Demographic Security of Ukraine» (project No. 4269 of 15.10.2003)]. rada.gov.ua. Retrieved from http://w1.c1.rada.gov.ua/pls/zweb2/webproc4_2?id=\&pf3516=4269\&skl=5 [in Ukraine].

2. Hladun, O.M. (2013). Otsinka hipotetychnykh vtrat naselennya Ukrayiny za period 1897-2012 rr. [Estimation of hypothetical losses of the population of Ukraine for the period of 1897-2012]. Demohrafiya ta sotsial'na ekonomika - Demography and Social Economy, 2(20), 147-155 - https://doi.org/10/15407/ dse2013.02.147 [in Ukrainian].

3. Levchuk, N.M. (2016). Kalendarna y kohortna tryvalist' zhyttya v Ukrayini: osoblyvosti dynamiky u dovhotryvaliy retrospektyvi [Calendar and cohort life expectancy in Ukraine: peculiarities of dynamics in the long-term retrospective]. Demohrafiya ta sotsial'na ekonomika - Demography and Social Economy, 1(26), 80-92 - https://doi.org/10/15407/dse2016.01.080 [in Ukrainian].

4. Libanova, E.M. (2014). Demograficheskie sdvigi v kontekste sotsialnogo razvitiya [Demographic shifts in the context of social development]. Demografiya ta sotsIalna ekonomika - Demography and Social Economy, 1(21), 9-23 - https://doi.org/10/15407/dse2014.01.009 [in Russian].

5. Rynhach, N. (2008). Minimizatsiya demohrafichnykh zahroz yak neobkhidnyy komponent polityky zabezpechennya natsional'noyi bezpeky Ukrayiny [Minimizing demographic threats as a necessary component of Ukraine's national security policy]. Efektyvnist' derzhavnoho upravlinnya - Effectiveness of public administration, 14/15, 140-145 [in Ukrainian].

6. Steshenko, V.S. (2013). Zmist ponyat' «demohrafichnyy rozvytok» i «lyuds'kyy rozvytok»: totozhnosti ta vidminnosti [Contents of the concepts of «demographic development» and «human development»: identities and differences]. Demohrafiya ta sotsial'na ekonomika. - Demography and Social Economy, 1(19), 5-16 - https://doi.org/10/15407/dse2013.01.005 [in Ukrainian].

7. Hnybidenko, I. (2007). Demohrafichni aspekty natsional'noyi bezpeky derzhavy [Demographic Aspects of National Security of the State]. Ukrayina: aspekty pratsi - Ukraine: aspects of labor, 5, 11-18 [in Ukrainian].

8. Dnistryans'kyy, M. (2017). Demohrafichna kryza v Ukrayini yak problema natsional'noyi bezpeky. Retrieved from http://bintel.com.ua/uk/article/09-22-demograph/ [in Ukrainian]. 
9. Tsvihun, I.A. (2013). Demohrafichna bezpeka Ukrayiny ta napryamy yiyi rehulyuvannya [Demographic security of Ukraine and directions of its regulation]. Kam'yanets'-Podil's'kyy: Vydavets' PP Zvoleyko D.H. [in Ukrainian].

10. Global Burden of Disease Study 2016 (2016) Data Resources. Retrieved from http://ghdx.healthdata. org/gbd-2016

11. The World Factbook (2017). Central Intelligence Agency. Retrieved from https://www.cia.gov/LIBRA$\mathrm{RY} /$ publications/the-world-factbook/rankorder/2066rank.html

12. The Official Site of Eurostat (2017). «Demography and Migration». Retrieved from http://ec.europa. eu/eurostat/data/database

13. Kharazishvili, Yu.M. (2019). Systemna bezpeka staloho rozvytku: instrumentariy otsinky, rezervy ta stratehichni stsenariyi realizatsiyi [Systemic Safety of Sustainable Development: Assessment Tool, Reserves and Strategic Implementation Scenarios]. Kyiv, NAN Ukrayiny, In-t ekonomiky prom-sti [in Ukrainian].

14. Kharazishvili, Yu.M., \& Hrishnova, O.A. (2018). Yakist' zhyttya v systemi sotsial'noyi bezpeky Ukrayiny: indykatory, riven', zahrozy [Quality of life in the system of social security in Ukraine: Indicators, level, threats]. Ekonomika Ukrayiny - Economy of Ukraine, 11-12, 157-171 [in Ukrainian].

15. Werner, I.E. (Ed.). (2018). Statystychnyy shchorichnyk Ukrayiny za 2017 [Statistical Yearbook of Ukraine for 2017]. State Statistics Service of Ukraine. [in Ukrainian].

16. Unated nations data retrieval system. (n.d.). Retrieved from http://data.un.org/Data.aspx?d=PopDiv$\& \mathrm{f}=$ variableID $\% 3 \mathrm{~A} 48$

17. Kharazishvili, Yu.M., \& Dron, Ye.V. (2015). Problemy intehral'noho otsinyuvannya rivnya ekonomichnoyi bezpeky derzhavy [Problems of the integrated assessment of the level of economic security of the state]. Bankivs'ka sprava - Banking, 1 (133), 3-21 [in Ukrainian].

18. Metodyka rozrakhunku rivnya ekonomichnoyi bezpeky Ukrayiny, zatverdzhena nakazom Minekonomiky Ukrayiny vid 02.03.2007 $r$. № 60 [Methodology for calculating the level of economic security of Ukraine, approved by the order of the Ministry of Economy of Ukraine dated March 02, 2007 No. 60]. (2007). Retrieved from: http://me.kmu.gov.ua/control/uk/publish/article? art_id [in Ukrainian].

19. Paniotto, V.I., Maksymenko, V.S., \& Marchenko, N.M. (2004). Statystychnyy analiz sotsiolohichnykh danykh [Statistical analysis of sociological data]. Kyiv: Vyd. dim KM Akademiya [in Ukrainian].

Стаття надійшла до редакції журналу 22.04.2019. 


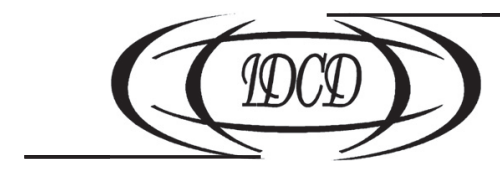

https://doi.org/10.15407/dse2019.02.081

УДК: 314.74(477)

JEL CLASSIFICATION: J61, O15

\section{І.П. МАЙДАНІК}

канд. соц. наук, старш. наук. співроб., старш. наук. співроб.

Інститут демографії та соціальних досліджень

імені М.В. Птухи НАН України

01032, Україна, м. Київ, бул. Т. Шевченка, 60

E-mail: Sulamif@online.ua

ORCID 0000-0003-0422-1364

\section{КОНТЕКСТУАЛЬНІ ПАРАМЕТРИ ЗВОРОТНОЇ ТРУДОВОЇ МІГРАЦІЇ В УКРАЇНУ}

Стаття присвячена дослідженню таких важливих параметрів зворотної трудової міграції в Україні як мотиваційна структура, роль членів родини в ухваленні рішення про повернення на батьківщину та рееміграційні стратегії. Робота грунтується на емпіричних даних, зібраних у ході вибіркового обстеження серед зворотних мігрантів ( 739 опитаних) та осіб без міграційного досвіду (509 опитаних), що було проведене протягом грудня 2017p. - липня 2018 р. у Львівській, Тернопільській, Івано-Франківській та Чернівецькій областях. Опитування було складовою частиною проекту «Тимчасова проти постійної міграціï ( Tетроrary versus permanent migration» (TEMPER)), виконаного на замовлення Європейської комісії у межах Сьомої Рамкової програми Свропейського Союзу (РП7). На основі емпіричних даних виявлено, що причинами вибуття за кордон є переважно трудові чинники, а повернення в Україну стимулюють сімейні фактори. Мотиви зворотної міграції з незначними варіаціями майже однакові для різних груп поверненців, незалежно від їхнього віку, статі, типу поселення та інших характеристик. З'ясовано, що на момент прибуття з-за кордонулише чверть усіх поверненців мають наміри залишитись на батьківщині назавжди. Переважна більшість зворотних мігрантів не мають чіткого налаштування на постійне повернення і повну самореалізацію в Україні, вони перебувають у невизначеному положенні стосовно вибору найсприятливішого для себе місия проживання. Така ситуація ставить виклики для демографічної та соціально-економічної безпеки держави і потребує адекватного реагування з боку органів, відповідальних за розробку і реалізацію міграційної політики.

Підтверджено положення нової економіки трудової міграції про те, що рішення як про міграцію за кордон, так і про повернення на батьківщину ухвалює не сам мігрант, а спільно усе домогосподарство. Згідно з результатами обстеження ТЕМПЕР, 40,2 \% опитаних зазначили, що рішення про їх повернення до України ухвалено ними за участю інших осіб. Однак більше половини респондентів, все-таки, самостійно вирішили завершити перебування за кордоном і повернутися. Невелика частка (4,1\%) опитаних поінформували, що рішення про повернення ухвалено повністю іншими особами; такі респонденти були змушені повернутися через сімейні зобов'язання, фінансові чи адміністративні складнощі або були депортовані.

Ключові слова: міграція, трудова міграція, зворотна міграція, циркулярна міграція, мігрант, зворотний мігрант.

( С МАЙДАНІК І.П., 2019

ISSN 2072-9480. Демографія та соціальна економіка, 2019, № 2 (36): 81-95 


\section{И.П. Майданик}

канд. соц. наук, стар. наук. сотруд., старш. науч. сотруд.

Институт демографии и социальных исследований

имени М.В. Птухи НАН Украины

01032, Украина, г. Киев, бул. Т. Шевченка, 60

E-mail: Sulamif@online.ua

ORCID 0000-0003-0422-1364

\section{КОНТЕКСТУАЛЬНЫЕ ПАРАМЕТРЫ ВОЗВРАТНОЙ ТРУДОВОЙ МИГРАЦИИ В УКРАИНУ}

Статья посвящена исследованию таких важных параметров возвратной трудовой миграции в Украине как мотивационная структура, роль членов семьи в принятии решения о возвращении на родину и реэмиграционные стратегии. Работа основана на эмпирических данных, собранных в ходе выборочного обследования среди возвратных мигрантов (739 опрошенных) и лии, без миграционного опыта (509 опрошенных), проведенного в декабря 2017 г. - июле 2018 г. во Львовской, Тернопольской, Ивано-Франковской и Черновицкой областях. Опрос был составной частью проекта «Временная против постоянной миграции» («Temporary versus permanent migration» (TEMPER)) и выполнен по заказу Европейской комиссии в рамках Седьмой рамочной программы Европейского Союза (РП7). На основе эмпирических данных показано, что причинами выбытия за рубежк служат преимущественно трудовые параметры, в то время как возвращение в Украину стимулируют семейные факторы. Мотивы возвратной миграции, с незначительными вариациями, почти одинаковы для разных групп мигрантов, независимо от их возраста, пола, типа населённого пункта и других характеристик. Установлено, что на момент прибытия из-за рубежа лишь четверть возвращенцев намерены остаться на родине навсегда. Подавляющее большинство возвратных мигрантов не имеют четко вырахенного предпочтения к постоянному возвращению и полной самореализации в Украине, они находятся в неопределенном положении относительно выбора наиболее благоприятного для себя места жительства. Такая ситуация ставит вызовы демографической и социально-экономической безопасности государства и требует адекватного реагирования со стороны органов, ответственных за разработку и реализацию миграционной политики.

В статье подтверждено положение новой экономики трудовой миграции о том, что решение как о миграции за рубеж, так и о возвращении на родину принимает не сам мигрант, а все домохозяйство. Согласно результатам обследования ТЕМПЕР, 40,2\% опрошенных приняли решение о возвращении в Украину вместе с другими лицами. Более половины респондентов все жее решили завершить пребывание за границей самостоятельно. 4,1\% опрошенных сообщили, что решение о возвращении принято всеиело другими лицами; такие респонденты были вынуждены вернуться из-за семейных обязательств, финансовых или административных сложностей либо были депортированы.

Ключевые слова: миграция, трудовая миграция, возвратная миграция, циркулярная миграция, мигрант, возвратный мигрант.

\section{I.P. Maidanik}

$\mathrm{PhD}$ (Sociology), senior research fellow

Ptoukha Institute for Demography and Social Studies of

National Academy of Science of Ukraine

01032, Ukraine, Kyiv, Taras Shevchenko Blvd., 60

E-mail: Sulamif@online.ua

ORCID 0000-0003-0422-1364

\section{CONTEXTUAL PARAMETERS OF RETURN LABOR MIGRATION TO UKRAINE}

The article is devoted to the study of such important parameters of return labor migration in Ukraine as motivational structure, the role of family in making a return decision and re-emigration strategies. The publication is based on the empirical data collected during the sample survey among the return migrants ( 739 respondents) and persons without migration experience (509 respondents), which was carried out during December 2017 - July 2018 in Lviv, Ternopil, Ivano-Frankivsk and Chernivtsi regions. The survey was a part of the project entitled "Temporary versus permanent migration" (TEMPER) which was supported by the European Commission under the Seventh Framework Program European Union (FP7). The article, based on empirical data, reveals that the reasons to 
go to work abroad are mainly of a labor character, while family factors stimulate returne to Ukraine. Reasons for return migration, with minor variations, are almost identical for different groups of returnees, regardless of age, sex, type of settlement and other characteristics. It was found that at the time of arrival only a quarter of returnees were intended to stay at homeland for good, while the vast majority of return migrants do not have a clear predisposition to permanent stay and full self-realization in Ukraine; they are in an indefinite position regarding the choice of the most favorable place for living. This situation poses challenges for the demographic and socio-economic security of the state and requires adequate response from the authorities responsible for the development and implementation of migration policy.

The article confirms the new economy of labor migration in its belief that the decision of both migration and returning is mostly a joint decision of the whole household. According to the results of the TEMPER survey, 40.2\% of the respondents noted that the decision to return to Ukraine was taken by them with the participation of other persons. However, more than half of respondents have decided to return on their own. A small share (4.1\%) of respondents has informed that the decision to return was made entirely by other persons; such respondents were forced to return due to family obligations, financial or administrative difficulties or were deported.

Keywords: migration, labor migration, return migration, circular migration, migrant, return migrant.

Постановка проблеми та актуальність теми. Різноманітні види, типи та форми міграції, що у кожний конкретний історичний момент набувають різного змістового забарвлення, формують загальне уявлення про калейдоскоп перебігу міграційних процесів. Зворотна міграція з'явилася на дослідницькій арені української науки однією $з$ останніх, тому вона досі не отримала достатньої уваги з боку експертів. Натомість іiі актуальність в умовах депопуляції та нестачі кваліфікованих кадрів на національному ринку праці, знелюднення окремих населених пунктів $є$ незаперечною.

Науковці використовують низку підходів для дослідження процесів зворотної міграції, при цьому вивчення намірів мігрантів щодо запланованої тривалості перебування за кордоном та настанов на повернення можна вважати найпростішим із методів. Такі дослідження здійснюють як на підготовчому етапі міграції, а також під час перебування в іноземній країні. Зазначений підхід викликає нарікання ряду експертів, оскільки первинні наміри особи не завжди відповідають ії подальшій поведінці. Емпіричний матеріал, на якому грунтується ця стаття, окреслює процеси фактичного, уже здійсненого, повернення. Перевагою такої інформації є те, що вона відображає реальні процеси, на противагу уявним міркуванням мігрантів про своє майбутнє.

Проте виключення вивчення намірів із матриці міграційних показників призведе до збіднення наукової дискусії, їх дослідницьке опрацювання варто посилити за рахунок уведення додаткових суміжних індикаторів, на кшталт виявлення рівня кінцевої реалізації початкових намірів, факторів, що визначають їх зміну тощо.

Аналіз останніх досліджень і публікацій. Вагомий дослідницький потенціал мають інтегральні розробки, що ураховують наміри щодо повернення до складу вихідних даних. Одним із таких напрацювань $є$ індекс орієнтації у бік дому (index of home orientation), запропонований румунським вченим Дімітру Санду (Dimitru Sandu) [1, c. 5]. Згаданий показник будується на основі трьох індикаторів: грошових переказів, інтенсивності спілкування з домом за допомогою телефону, е-пошти тощо та наміри повернутися у країну виїзду.

Еволюція категоріального апарату, який використовують для дослідження зворотної міграції, відображає трансформацію внутрішнього змісту цих процесів. У другій половині XX ст. у книзі М. Анвара (М. Anwar), присвяченій мігрантам з Пакистану у Великій Британії [2], було введено у науковий обіг поняття «міф про повернення», яке на тривалий час стало популярним серед зарубіжних дослідників. Пізніше воно зазнало трансформацій, і на його грунті виникли суміжні поняття - «віра у повер- 
нення» та «надії на повернення» [3]. Ж.-П. Кесcаріно (J.-P. Cessarino), який є знаковою фігурою у колі міграційних експертів, запровадив концепцію «підготовки до повернення» (return preparedness) [4], що описує реалізовану поведінку особи і певною мірою протиставляється уявним чи непевним настроям мігрантів щодо повернення, які домінують у поняттях, що наведені раніше.

Українські дослідники активно долучаються до міжнародної наукової дискусії з проблематики зворотної міграції. Грунтовні розробки з цієї тематики, де поглиблено розглянуто особливості вітчизняного контексту, наявні у публікаціях О. Іванкової-Стецюк (O. Ivankova-Stetsyuk), Е. Лібанової (Е. Libanova), О. Малиновської (O. Malinovska), I. Прибиткової (I. Pribitkova), О. Позняка (O. Poznyak), У. Садової (V. Sadova) та інших вчених.

Мета статті - визначити структуру мотиваційних факторів, які стимулюють зворотну трудову міграцію в Україну, оцінити роль домогосподарств у процесі ухвалення рішення про повернення, дослідити рееміграційні настанови поверненців.

Новизна. У статті удосконалено систематизацію та наукове розуміння мотиваційних чинників зворотної міграції українців, уперше виявлено комунікаційні поведінкові зразки у процесі ухвалення рішення про повернення трудових мігрантів в Україну.

Методологія і характеристика вибірки. Основою для написання статті слугує інформація, зібрана у ході дослідження, проведеного в рамках проекту «Тимчасова проти постійної міграції» (ТЕМПЕР) ${ }^{1}$. Обстеження виконано з використанням майже ідентичної анкети в Аргентині, Сенегалі, Румунії та Україні. На території нашої країни у межах дослідження зібрано інформацію про осіб, які здійснили міграції за кордон (в Італію або Польщу) у 1996 р. і пізніше, та повернулися в Україну у 2000 р. і пізніше. Мінімальна тривалість перебування і працевлаштування за кордоном в опитаних осіб - два місяці.

3 метою виключення з обстеження мігрантів, які повернулися в Україну для відвідання родини та друзів або у відпустку, дослідницькою командою було вирішено ввести часовий критерій мінімального строку перебування на батьківщині після повернення - два місяці. 3 огляду на те, що переважна більшість українців, які працюють у двох вищеназваних країнах $\mathrm{CC}$, походять із західних регіонів країни, дослідження організовано у Львівській, Тернопільській, Івано-Франківській та Чернівецькій областях. У кожному з цих регіонів обрано обласний центр та три-чотири райони 3 населеними пунктами різних типів (місто, село, селище міського типу).

Для пошуку респондентів із міграційним досвідом застосовано метод снігової кулі. Відбір первинних контактів для побудови наступного ланцюга здійснено у неурядових організаціях, які працюють із колишніми мігрантами або займаються питаннями боротьби з торгівлею людьми, на тематичних онлайн форумах, у школах, садочках, сільрадах, релігійних установах тощо. Родзинкою дослідження стала

\footnotetext{
${ }^{1}$ Проект «Тимчасова проти постійної міграції» (Temporary versus permanent migration (TEMPER)) виконано на замовлення Європейської комісії у межах Сьомої Рамкової програми Європейського Союзу (РП7). Для здійснення наукової та адміністративної роботи за проектом було створено консорціум з дев'яти дослідницьких організацій, розташованих у семи країнах світу (Аргентині, Великій Британії, Іспанії, Італії, Румунії, Україні та Франції). Координатором проекту була Національна дослідницька Рада Іспанії (Spanish National Research Council), розташована у Мадриді. Україну у складі виконавчого колективу представляє Інститут демографії та соціальних досліджень імені М.В. Птухи НАН України (ІДСД). Польовий етап емпіричного дослідження в Україні виконав центр «Соціальний моніторинг» на замовлення ІДСД. Строки виконання проекту 01.03.2014 31.08.2018, польового етапу дослідження - грудень 2017 р. - липень 2018 р. Офіційний веб-сайт: http://www. temperproject.eu/
} 
процедура опитування, здійснюваного за допомогою планшета з програмним забезпеченням, розробленим спеціально для цього у рамках проекту ТЕМПЕР.

Для порівняння життєвих траєкторій та поглядів зворотних мігрантів із населенням загалом, опитано також мешканців відповідних областей та населених пунктів без досвіду працевлаштування за кордоном, яким поставлено ідентичні запитання, за винятком блоку питань про міграційний досвід. Респондентів без міграційного досвіду обирали відповідно до загального розподілу населення цільових областей за статтю, віком та типом поселення.

У цій статті викладено результати порівняння поверненців та немігрантів стосовно їхніх (ре)еміграційних настанов.

Загалом у ході дослідження було опитано 739 зворотних мігрантів з Італії та Польщі та 509 осіб без міграційного досвіду. На початковому етапі дослідження було заплановано опитати однакову кількість представників кожної з категорій, однак у ході обстеження виявилося переважання у вибірці мігрантів, які повернулися нещодавно - 2017 року. У зв’язку з цим та для повнішого представлення більш раннього досвіду повернення, було вирішено додатково опитати мігрантів, які повернулися у 2014 р. і раніше.

Дослідження охоплювало осіб віком 20-74 роки. Вибір респондентів такого віку визначено завданнями дослідження та структурою анкети: осіб старших вікових груп (75 років і старші) не розглядали як потенційних респондентів, оскільки анкета містить низку питань про майбутні плани опитаних (інвестиції, наміри щодо майбутнього працевлаштування за кордоном тощо), а майбутнє представників старшого населення у силу вікових особливостей найчастіше наповнено іншим змістом, не пов'язаним 3 продовженням професійної реалізації. Особи, молодші за 20 років, були виключені 3 числа опитаних, оскільки ще не встигли набути достатнього трудового та міграційного досвіду, крім того, існує велика ймовірність, що їх працевлаштування за кордоном є радше частиною сімейного проекту, а не самостійним вибором.

Ураховуючи особливості статевого складу українських мігрантів у різних країнах призначення, вибірку респондентів, які повернулися з Польщі, порівну розподілили між групами чоловіками та жінками, а переважну більшість $(70,2 \%)$ опитаних 3 досвідом працевлаштування в Італії складали жінки.

Виклад основного матеріалу. Причини виїзду за кордон та повернення на батьківщину для респондентів дослідження ТЕМПЕР разюче відмінні: переважна більшість опитаних поїхали за межі України з економічних мотивів (нестабільна робота, низька зарплата, відсутність можливості працевлаштуватися, незадоволеність роботою в Україні тощо), а повернулися - з сімейних (на вимогу членів родини, для возз'єднання сім’ї або у результаті припинення шлюбних стосунків та ін.) (табл. 1). У структурі мотиваційних чинників повернення в Україну велике значення мають також фінансові, адміністративні та емоційні фактори.

Дослідження майже не виявило різниці у структурі причин повернення мігрантів із Польщі та Італії: поверненці з першої з названих країн дещо частіше (на 11,8 в. п.) поверталися в Україну з адміністративних причин, а з другої - з емоційних (на 10,1 в. п.). Остання теза є досить логічною, оскільки за своєю культурою, мовою, кліматом, харчуванням, стилем життя та іншими характеристиками Італія відрізняється від України набагато суттєвіше, аніж Польща.

Причини повернення українських мігрантів на батьківщину певною мірою визначені їхніми віковими характеристиками, які обумовлюють і наповненість 
Таблиия 1. Причини виїзду за кордон та повернення в Україну зворотних мігрантів, \%

\begin{tabular}{|c|c|c|}
\hline \multicolumn{2}{|r|}{ Причини мобільності } & \multirow{2}{*}{$\begin{array}{c}\begin{array}{c}\text { Частка } \\
\text { респондентів, \% }\end{array} \\
8,5\end{array}$} \\
\hline \multirow{7}{*}{ : } & $\begin{array}{l}\text { Сімейні фактори (сім’я змушує мігрувати / возз'єднання родини / } \\
\text { щоб діти жили в Європі) }\end{array}$ & \\
\hline & Відсутність можливості працевлаштуватися в Україні & 31,5 \\
\hline & Нестабільна робота, низька зарплата в Україні & 58,1 \\
\hline & Незадоволення моєю роботою в Україні & 14,1 \\
\hline & Отримав(ла) гарну пропозицію роботи за кордоном & 17,6 \\
\hline & Прагнення спробувати щось нове & 8,1 \\
\hline & Інше & 17,2 \\
\hline \multirow{11}{*}{ 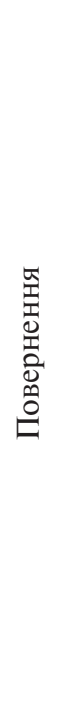 } & Родина в Україні вимагала повернутися & 31,0 \\
\hline & 3 метою одруження, пошуку чоловіка (дружини) & 3,5 \\
\hline & Для возз’єднання / перебування з родиною & 11,8 \\
\hline & Через розлучення & 22,0 \\
\hline & $\begin{array}{l}\text { Закінчення трудової угоди / припинення моєї роботи в Італії / Поль- } \\
\text { щі }\end{array}$ & 14,6 \\
\hline & $\begin{array}{l}\text { Відсутність можливості працевлаштуватися в Італії / Польщі; незадо- } \\
\text { воленість роботою }\end{array}$ & 6,5 \\
\hline & Щоб завершити навчання & 2,6 \\
\hline & $\begin{array}{l}\text { Закінчення терміну дії візи / непоновлення дозволу на проживання / } \\
\text { роботу / вирішення правових питань }\end{array}$ & 17,6 \\
\hline & $\begin{array}{l}\text { Ностальгія: сум за родиною, друзями, харчуванням, стилем життя, } \\
\text { відчуття приналежності до України }\end{array}$ & 19,3 \\
\hline & Проблеми зі здоров'ям & 5,1 \\
\hline & Інше & 20,4 \\
\hline
\end{tabular}

Примітка. Сума часток у табл. 1 більша за $100 \%$, оскільки респонденти могли назвати дві основні причини для від’їду та повернення.

Джерело: результати опитування у рамках проекту ТЕМПЕР.

життєвих смислів у представників різних вікових груп. Наймолодші мігранти (віком 20-29 років) лише у половині випадків повернулися в Україну під впливом сімейних факторів, старші респонденти вказували на відповідну причину у трьох чвертях випадків і більше (табл. 2). Кожен десятий опитаний, який ще не розміняв четвертий десяток, зауважив, що повернувся на батьківщину з огляду на навчальні мотиви, а для інших категорій мігрантів вплив цього чиннику був непомітним або відсутнім, що цілком зрозуміло, адже здобуття освіти є важливим кроком для професійного становлення та отримання певного соціального статусу і відбувається у сучасних українських умовах переважно на ранніх життєвих етапах. Ностальгія, сум за родиною та інші емоційні причини найчастіше спонукали до повернення найстарших та наймолодших респондентів; вага адміністративних мотивів зменшувалася разом зі зростанням віку опитаних; фінансові та трудові чинники помітно частіше називали респонденти віком 20-29 та 40-49 років. 
Таблиия 2. Причини зворотної міграції представників різних статево-вікових та поселенських груп, \%

\begin{tabular}{|l|c|c|c|c|c|c|c|c|}
\hline \multirow{2}{*}{ Причини } & \multicolumn{4}{|c|}{ За віком } & \multicolumn{2}{c|}{ За статто } & \multicolumn{2}{|c|}{$\begin{array}{c}\text { За типом по- } \\
\text { селення }\end{array}$} \\
\cline { 2 - 10 } & $\begin{array}{c}\mathbf{2 0 - 2 9} \\
\text { років }\end{array}$ & $\begin{array}{c}\mathbf{3 0 - 3 9} \\
\text { років }\end{array}$ & $\begin{array}{c}\mathbf{4 0 - 4 9} \\
\text { років }\end{array}$ & $\mathbf{5 0 +}$ & Жінки & $\begin{array}{c}\text { Чолові- } \\
\text { ки }\end{array}$ & Село & Місто \\
\hline Сімейні & 50,0 & 78,4 & 86,3 & 79,5 & 80,0 & 64,7 & 73,5 & 75,0 \\
\hline Фінансові / трудові & 30,2 & 19,5 & 29,1 & 23,7 & 21,8 & 30,2 & 29,3 & 17,0 \\
\hline Навчальні & 11,6 & 2,1 & 0,6 & 0 & 3,8 & 3,1 & 3,6 & 3,4 \\
\hline $\begin{array}{l}\text { Адміністративні / бюро- } \\
\text { кратичні }\end{array}$ & 26,7 & 20,3 & 13,7 & 11,5 & 15,1 & 23,4 & 19,5 & 16,6 \\
\hline Емоційні & 28,5 & 19,5 & 12,0 & 25,0 & 23,0 & 18,0 & 19,9 & 23,0 \\
\hline Стиль життя / смаки & 1,7 & 3,4 & 2,9 & 0,6 & 1,8 & 3,1 & 6,3 & 4,2 \\
\hline Інше & 5,2 & 8,5 & 9,1 & 16,0 & 9,0 & 10,2 & 8,9 & 10,6 \\
\hline
\end{tabular}

Примітка. Сума часток у табл. 2 більша за 100 \%, оскільки респонденти могли назвати дві основні причини для від’їду та повернення.

Джерело: результати опитування у рамках проекту ТЕМПЕР.

Статеві відмінності у мотивації респондентів на повернення є несуттєвими. Вмотивованість до повернення жінок дещо частіше обумовлена емоційною складовою та сімейними факторами (табл. 2), серед останніх найпомітніша різниця (у 9,6 в. п.) між представниками різних статей виявляється у частці опитаних, які причиною повернення на батьківщину назвали розлучення. Представники чоловічої статі трохи частіше вказували на фінансово-трудові та адміністративно-бюрократичні мотиви. Причини повернення респондентів із населених пунктів різних типів майже не відрізняються, єдина незначна відмінність полягає у тому, що селяни дещо частіше (на 12,3 в. п.) повертаються із фінансових та трудових причин.

Загалом, як міграції за кордон, так і повернення в Україну, згідно з результатами обстеження ТЕМПЕР, є значною мірою моновмотивованими: незважаючи на те, що у ході опитування респонденти могли назвати дві причини виїзду та повернення, велика частка опитаних обмежилися озвучуванням лише одного мотиваційного фактору (44,9 \% стосовно міграції та 45,6 \% щодо повернення).

Переважна більшість опитаних задоволені своїм рішенням повернутися в Україну: майже третина $(31,1 \%)$ - задоволені повністю, ще 41,9\% - більшою мірою (рис. 1). Лише 10,0\% респондентів висловили повне або часткове незадоволення своїм рішенням щодо повернення. Різниця між рівнем задоволення від повернення на батьківщину у представників різних вікових та статевих груп виявилася несуттєвою; респонденти з досвідом перебування в Італії висловлювали (повне або часткове) незадоволення від повернення в Україну частіше за поверненців із Польщі (14,1 та 5,9 \% відповідно); майже така сама різниця між частками незадоволених респондентів із сільських населених пунктів та міст (7,8 та 14,0 \% відповідно).

Переважна більшість зворотних мігрантів на момент повернення в Україну мали конкретне уявлення про тривалість майбутнього перебування на батьківщині, лише кожен десятий опитаний із міграційним досвідом заявив про протилежне, при чому зі зростанням віку респондентів питома вага осіб з невизначеними намірами стабільно зменшується. Чверть опитаних $(25,3 \%)$ пов'язували своє повернення 3 


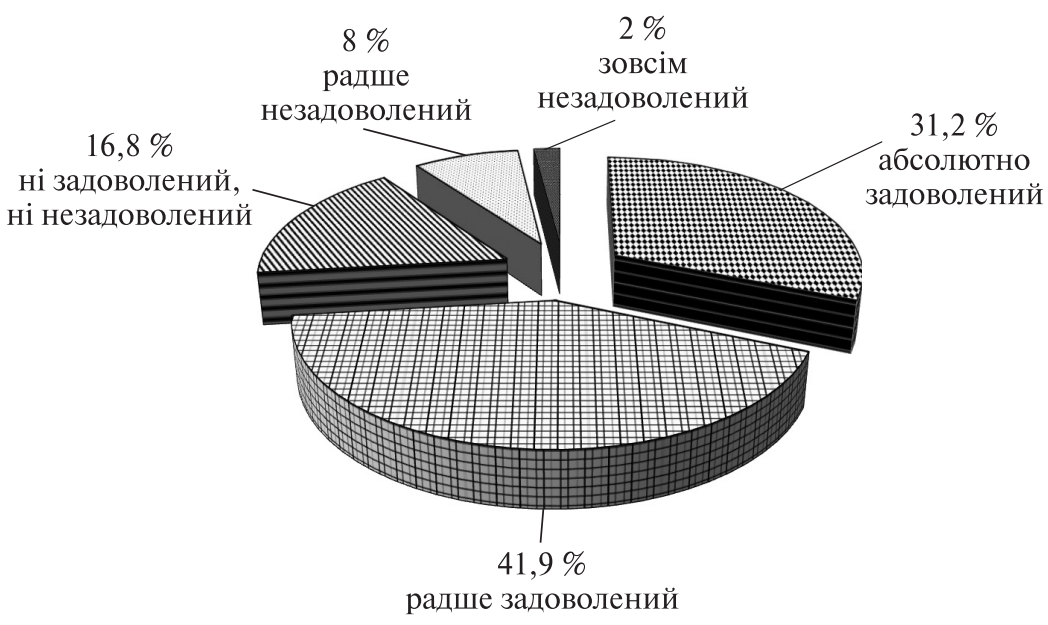

Рис. 1. Розподіл відповідей респондентів на запитання «Чи задоволені ви своїм рішенням повернутися до України?», \%

Джерело: результати опитування у рамках проекту ТЕМПЕР.

завершенням «міграційної кар'єри»; кожен третій $(32,1 \%)$ планував пробути на батьківщині від трьох місяців до року, майже кожен четвертий $(22,6 \%)$ - понад рік, але не завжди. Лише незначний контингент $(2,4 \%)$ мав намір пробути в Україні менше трьох місяців.

Настанови представників різних статей щодо запланованої тривалості перебування в Україні після повернення відрізнялися несуттєво. У розрізі типів населених пунктів - містяни дещо частіше заявляли про свої наміри щодо остаточного повернення, а селяни - про плани пробути на батьківщині понад рік, але не постійно. Серед поверненців із Польщі частка осіб, які планували пробути в Україні від трьох до дванадцяти місяців, була на 9,4 в. п. вищою, ніж тих, хто працював в Італії, і становила $36,8 \%$. Серед останніх було більше осіб, які заявили про остаточне повернення, що підкреслює різницю у характері міграційних поїздок наших співвітчизників до визначених країн, де перебування у Польщі частіше мають короткотривалий та циклічний характер.

Нині у значній кількості теоретичних та практичних розробок з міграційної проблематики наголошено на зв'язках між міграціями та соціально-економічним розвитком, прослідковано роль зворотних мігрантів як можливих агентів позитивних зрушень для країн свого походження. У таких умовах те, що лише чверть усіх поверненців на момент прибуття на батьківщину мають наміри залишитись тут назавжди, показує, що потенціал позитивних змін у результаті зворотної міграції є досить обмеженим. Це є тривожним сигналом для держави, оскільки переважна більшість мігрантів не мають чіткого налаштування на постійне повернення і повну самореалізацію в Україні: вони невизначились із вибором найліпшого для себе місця проживання. 3 іншого боку, така невизначеність є підставою для певного оптимізму, оскільки мігранти виїжджають не назавжди, підтримують міцні зв'язки з батьківщиною, отже є надія на їх повернення та можливість залучити їх до розбудови власного краю. У сучасній міграційній літературі існує поняття «війни або змагання за таланти» [5, с. 43], яке означає змагання між країнами за кваліфікований людський капітал, який на сьогодні є одним із найважливіших факторів прогресу. У такому ракурсі 


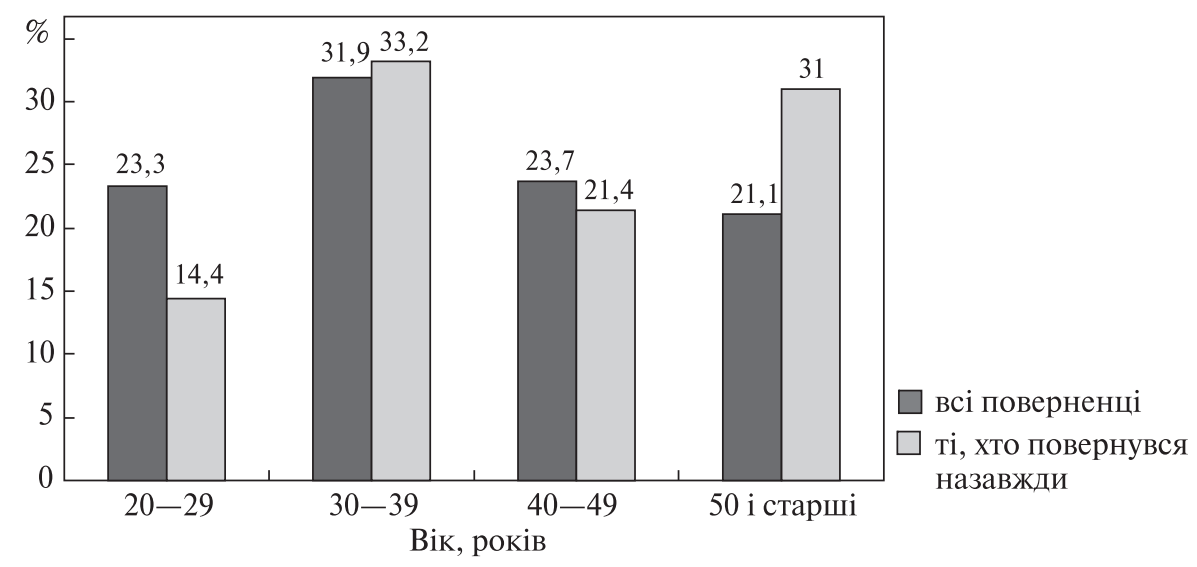

Рис. 2. Віковий розподіл зворотних мігрантів залежно від запланованої тривалості перебування на батьківщині, \%

Джерело: результати опитування у рамках проекту ТЕМПЕР.

найважливіше змагання, яке повинна виграти Україна - це повернути власних громадян, які працюють за кордоном, та забезпечити їм гідні умови праці та проживання, щоб вони, в свою чергу, робили внесок у розбудову країни.

Статева структура всіх зворотних мігрантів та тих, хто повернувся назавжди, майже ідентична: серед обох підгруп переважають жінки (60,1 та 61,5 \% відповідно). Дуже схожим є також розподіл обох категорій залежно від типу населеного пункту, з незначною перевагою селян (64,1 та 58,3 \% відповідно). Серед опитаних, які повернулися назавжди, помітно меншою є частка наймолодших контингентів, і помітно більшою - питома вага найстарших (рис. 2). Середній вік остаточних поверненців є найвищим і складає 42,7 року; наймолодшими (34,3 роки) є ті, хто повернувся на найкоротший термін. Відповідний показник тих опитаних, хто планував після повернення пробути в Україні від трьох до дванадцяти місяців та більше року, але не завжди, є майже однаковим (38,9 та 38,8 року). Також порівняно молодими $(36,4$ роки) виявилися особи, які не визначилися стосовно тривалості свого повернення, очевидно, що багато з них - молодь, у якої ще не сформувалися чіткі преференції стосовно бажаного місця проживання та працевлаштування.

3 огляду на те, що третина остаточних поверненців мають вік понад 50 років, очевидно, що помітну частину їх становлять ті, хто здійснив «повернення через вихід на пенсію» [4, с. 258]. Певна частка старших респондентів можуть здійснювати трудову та соціальну активність на батьківщині, робити важливий внесок у розбудову держави, але загалом інвестиційний, інноваційний та трудовий потенціал цієї категорії осіб є великою мірою вичерпаним.

Прихильники нової економіки трудової міграції стверджують, що рішення як про міграцію за кордон, так і про повернення на батьківщину мігрант не ухвалює самостійно, воно є спільною ухвалою всього домогосподарства. Результати обстеження ТЕМПЕР підтверджують, що така практика $є$ досить поширеною серед українців, оскільки 40,2 \% опитаних зазначили, що рішення щодо їх повернення до України було ухвалено ними за участю інших осіб. Однак більше половини респондентів все-таки самостійно вирішили завершити перебування за кордоном і повернутися. Невелика частка $(4,1 \%)$ опитаних поінформували, що рішення про повернення належало 
цілком іншим особам. Такі респонденти переважно працювали в Італії, декілька 3 них були депортовані, інші були змушені повернутися через сімейні зобов'язання, фінансові чи адміністративні складнощі.

Містяни, жінки та респонденти, які працювали в Італії, більшою мірою враховували думку інших осіб для рішення щодо повернення в Україну, однак ця різниця $є$ незначною у порівнянні з носіями протилежних ознак (6-7 в. п.) (табл. 3). У віковому розрізі опитування показало, що наймолодші респонденти (20-29 років) найчастіше спираються лише на власну думку для ухвалення рішення про повернення, далі зі зростанням віку підвищується роль інших осіб у такому рішенні, яка дещо слабшає для найстарших респондентів (віком 50 років і більше). Таку ситуацію можна пояснити особливостями сімейних зобов'язань у населення різних вікових груп: наймолодші респонденти часто ще не перебувають у шлюбі та не мають дітей, тож почуваються вільними і самостійно визначають напрям своєї життєвої траєкторії; діти найстарших опитаних уже вийшли з малолітнього віку і не потребують батьківського піклування, натомість середній вік є часом найбільш активної побудови сімейних стосунків, народження та виховання чергових поколінь, що впливає і на формування міграційної поведінки. Доволі промовистим виглядає той факт, що як наявність дітей, так і наявність шлюбного партнера в опитаних, впливають на рівень їх самостійності в ухваленні рішення про завершення міграції та повернення на батьківщину, однаково: серед респондентів, які не мають дітей та не перебували у шлюбі на момент опитування, лише трохи більше чверті брали до уваги думку інших осіб стосовно доцільності повернення до України, а одружені респонденти та ті, які мають дітей, врахували думку інших майже у половині випадків.

У регіональному розрізі поведінка респондентів із Чернівецької області щодо самостійності рішення про повернення суттєво відрізняється від опитаних із інших областей. У Львівській, Івано-Франківській та Тернопільській областях близько

Таблиия 3. Розподіл відповідей респондентів на запитання «Рішення про повернення до України було прийнято вами самостійно або за участі інших осіб?» залежно від віку, шлюбного стану та наявності дітей, \%

\begin{tabular}{|l|c|c|c|}
\hline \multicolumn{1}{|c|}{$\begin{array}{c}\text { Варіанти відповіді на аналізоване запитання } \\
\text { анкети }\end{array}$} & $\begin{array}{c}\text { Повністю } \\
\text { мною }\end{array}$ & $\begin{array}{c}\text { Повністю іншими } \\
\text { особами }\end{array}$ & $\begin{array}{c}\text { Мною та } \\
\text { іншими }\end{array}$ \\
\hline \multicolumn{5}{|c|}{ Вікові групи } \\
\hline $20-29$ & 61,60 & 2,30 & 35,50 \\
\hline $30-39$ & 57,20 & 3,40 & 39,00 \\
\hline $40-49$ & 46,30 & 7,40 & 45,70 \\
\hline $50+$ & 55,1 & 3,2 & 41,7 \\
\hline \multicolumn{5}{|c|}{ Перебування у шиюбі } \\
\hline Перебуває у шлюбі & 46,30 & 3,80 & 49,20 \\
\hline Не перебуває у шлюбі & 68,70 & 4,40 & 26,50 \\
\hline \multicolumn{5}{|c|}{ Наявність дітей } \\
\hline С діти & 48,10 & 4,20 & 47,10 \\
\hline Немає дітей & 68,60 & 3,70 & 27,30 \\
\hline
\end{tabular}

Джерело: результати опитування у рамках проекту ТЕМПЕР. 


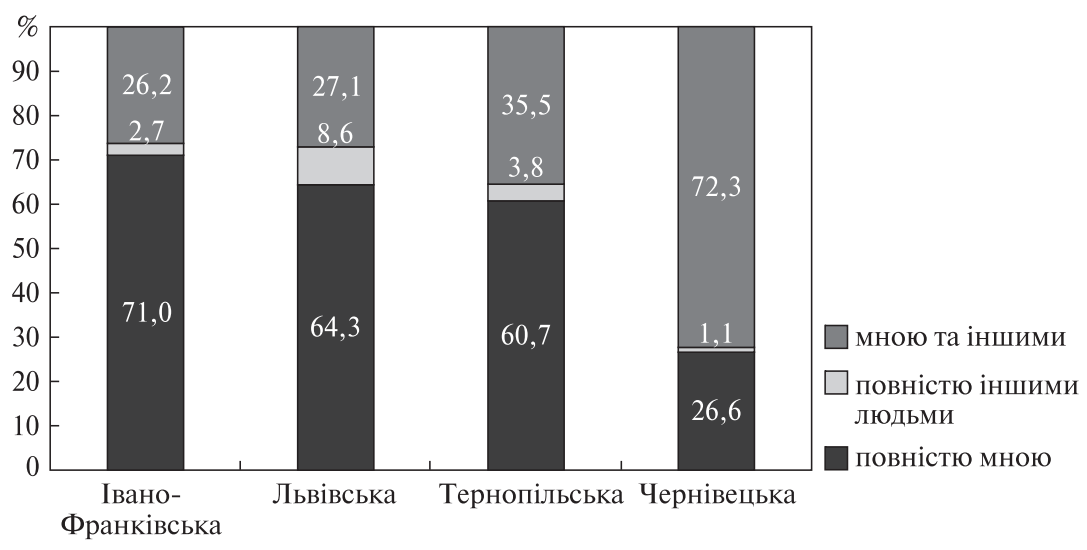

Рис. 3. Розподіл респондентів залежно від області опитування та відповіді на запитання «Рішення про повернення до України було прийнято вами самостійно або за участі інших осіб?», \%

Джерело: результати опитування у рамках проекту ТЕМПЕР.

двох третин опитаних зазначили, що вирішили повертатись самостійно, незначні частки $(2,7-8,6 \%)$ повернулися через рішення інших осіб, інші ухвалювали рішення спільно з іншими особами. Натомість у Чернівецькій області розподіл відповідей був протилежним (рис. 3). За своєю статево-віковою та поселенською структурою, розподілом опитаних між країнами призначення, всі області, охоплені дослідженням, відрізняються несуттєво. Тому пояснити таку відмінність у поведінкових стратегіях щодо повернення серед мешканців визначеного регіону за допомогою інформації лише з аналізованого обстеження неможливо, для вирішення цього питання необхідним є виконання додаткових досліджень.

3 огляду на важливу роль сімейних факторів в ухваленні ключових рішень у міграційних проектах, місце проживання родини респондентів є важливим фактором, що вибудовує контекст повернення. На момент повернення в Україну у більшості респондентів на батьківщині перебували батьки, майже у половини - подружжя, у третини - неповнолітні діти, майже у кожного п'ятого - дорослі нащадки, у досить помітної частини опитаних - брати та сестри (табл. 4). Разом з тим, лише незначні частки респондентів на момент повернення залишили за кордоном членів родини. Така картина ілюструє, що у ситуації вибору майбутнього місця проживання між країною призначення та батьківщиною сімейні зв’язки є потужним фактором притягання до України, акт виїзду за кордон та повернення здійснюється переважно одноосібно. Однак цей висновок стосується лише вибіркової сукупності даного обстеження (тобто тих осіб, які вже повернулися після працевлаштування з-за кордону) і не може поширюватися на всі категорії мігрантів. Зазначена інформація, отримана у ході обстеження ТЕМПЕР, не заперечує поширеності явища возз'єднання українських родин за кордоном, масштабних процесів сімейної міграції, коли за кордон від’їжджають домогосподарства у повному складі. Для аналізу цих процесів необхідно здійснювати спеціальні дослідження, ураховуючи специфіку конкретних міграційних потоків під час формування вибірки.

(Ре)міграційні настрої. Згідно з результатами дослідження ТЕМПЕР, категорія опитаних зворотних мігрантів розділилася на дві майже однакові за розміром групи стосовно їхніх планів поїхати за кордон у наступні п’ять років або залишитися 
Таблиця 4. Розподіл зворотних мігрантів залежно від місця проживання членів родини на момент повернення в Україну, \%

\begin{tabular}{|c|c|c|c|}
\hline \multirow[t]{2}{*}{ Члени родини } & \multirow{2}{*}{$\begin{array}{c}\text { На момент } \\
\text { повернення } \\
\text { проживали } \\
\text { в Україні }\end{array}$} & \multicolumn{2}{|c|}{$\begin{array}{c}\text { На момент повернення проживали } \\
\text { в країні працевлаштування }\end{array}$} \\
\hline & & Так & $\begin{array}{c}\text { Так, але повернулися разом } \\
\text { з респондентом }\end{array}$ \\
\hline Батько & 66,8 & 1,2 & 0,1 \\
\hline Мати & 78,6 & 5,9 & 0,3 \\
\hline Брат(и) & 40,2 & 2,9 & 0,5 \\
\hline Сестра(и) & 41,6 & 4,3 & 0,3 \\
\hline Чоловік / дружина & 47,6 & 3,7 & 2,0 \\
\hline Неповнолітні діти & 34,6 & 0,4 & 0,7 \\
\hline Повнолітні діти & 21,8 & 1,5 & 0,1 \\
\hline Інші особи, важливі для респондента & 80,0 & 23,7 & 1,5 \\
\hline
\end{tabular}

Джерело: результати опитування у рамках проекту ТЕМПЕР.

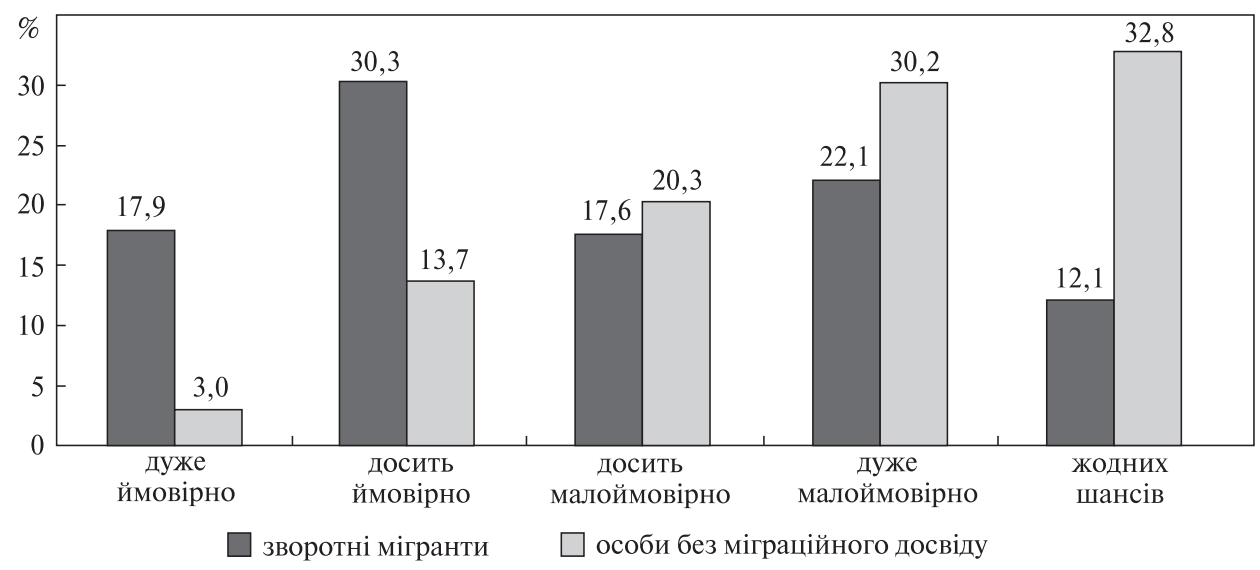

Рис. 4. Розподіл відповідей респондентів на запитання «Наскільки ймовірно те, що ви поїдете за кордон у найближчі два роки?» залежно від наявності міграційного досвіду, \%

Джерело: результати опитування у рамках проекту ТЕМПЕР.

на батьківщині (47,2 та 43,6 \% відповідно); майже кожен десятий не визначився 3 відповіддю на це запитання. Показовим є те, що ситуація щодо міграційних намірів у визначений термін для опитаних осіб, які не мають досвіду працевлаштування за кордоном, кардинально відрізняється: залишитися в Україні планують майже дві третини (65,8 \%), а поїхати за кордон - лише трохи більше чверті (26,9 \%). Такі дані вкотре підтверджують той факт, що в Україні поширеною є практика циркулярних поїздок за кордон, а наявність міграційного досвіду в особи збільшує ймовірність ії майбутнього виїзду з країни на певний термін або назавжди.

Разом з тим, виходячи з наявних ресурсів, ситуації в країнах походження та призначення та інших факторів, досить часто бажання людей розходяться з їхніми фактичними діями. 3 цієї причини у ході дослідження було вирішено уточнити вище 
Таблиця 5. Причини, з яких респонденти налаштовані поїхати за кордон або залишитись в Україні у найближчі два роки, \%

\begin{tabular}{|l|c|c|c|c|}
\hline \multirow{2}{*}{ Причини } & \multicolumn{2}{|c|}{$\begin{array}{c}\text { Причини залишитись } \\
\text { в Україні }\end{array}$} & \multicolumn{2}{c|}{$\begin{array}{c}\text { Причини поїхати за кордон } \\
\text { у найближчі два роки }\end{array}$} \\
\cline { 2 - 5 } & $\begin{array}{c}\text { 3воротні } \\
\text { мігранти }\end{array}$ & Немігранти & $\begin{array}{c}\text { 3воротні } \\
\text { мігранти }\end{array}$ & Немігранти \\
\hline Сімейні & 47,3 & 43,6 & 10,9 & 11,1 \\
\hline Фінансові / трудові & 14,2 & 16,0 & 72,3 & 72,2 \\
\hline Навчальні & 0,4 & 1,1 & - & - \\
\hline Адміністративні, бюрократичні & 4,6 & 2,4 & 0,6 & - \\
\hline Емоційні & 13,9 & 14,5 & 1,8 & 2,6 \\
\hline Спосіб життя / смаки & 4,7 & 6,5 & 11,6 & 10,5 \\
\hline Інше & 14,9 & 14,9 & 2,6 & 2,6 \\
\hline
\end{tabular}

Джерело: результати опитування у рамках проекту ТЕМПЕР.

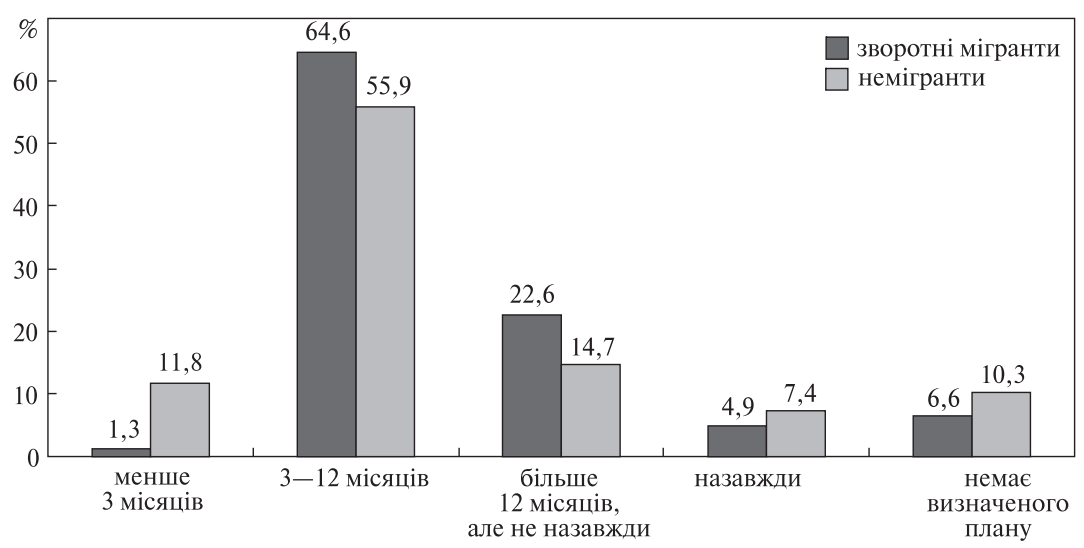

Рис. 5. Розподіл респондентів, які планують поїхати за кордон у наступні два роки, залежно від тривалості запланованого виїзду та наявності міграційного досвіду, \%

Джерело: результати опитування у рамках проекту ТЕМПЕР.

наведені настанови респондентів запитанням щодо реальної ймовірності їх виїзду за кордон протягом найближчих двох років (даний часовий горизонт було зменшено 3 п’яти до двох років, через припущення, що реальні настанови втілюються у життя протягом найближчого часу, а не відкладаються на віддалену перспективу). Незважаючи на зміну фокусу запитання з виявлення бажань до дослідження настанов реальної поведінки та скорочення часового періоду, отримана інформація несподівано виявилася досить схожою: про високу ймовірність виїзду за кордон у найближчі два роки заявили майже половина зворотних мігрантів і лише кожен шостий респондент без міграційного досвіду (рис. 4).

Незважаючи на наявність значної різниці у намірах щодо виїзду за кордон у найближчі роки у зворотних мігрантів та респондентів без міграційного досвіду, структура мотиваційних чинників, що обумовлюють як виїзд за кордон, так і бажання залишитись на батьківщині, в обох категорій опитаних є досить 
однорідною. Переважна більшість тих, хто засвідчив високу ймовірність свого майбутнього виїзду за кордон, сформували такі наміри виходячи з фінансових чи трудових причин, а найважливішими підставами для того, щоб залишитись на батьківщині, є сімейні фактори (табл. 5). Такі дані обстеження збігаються з інформацією, наведеною на початку цієї статті щодо причин уже здійснених міграцій та повернення. Таким чином, попри те, що мова йде про реалізовані чи потенційні міграції для різних категорій респондентів, сімейні зв'язки є фактором, що закріплюють людей у місцях проживання, а трудові змушують до виїзду за кордон.

Серед зворотних мігрантів, які у найближчі два роки планують знову виїхати за кордон, більше половини опитаних $(60,1 \%)$ мають наміри повторити поїздку до тієї країни, де вони працювали минулого разу, кожен п’ятий (20,5 \%) - в іншу європейську державу, кожен десятий ще не визначився. Частка осіб із невизначеними намірами щодо країни майбутнього виїзду серед немігрантів є удвічі більшою, майже дві третини планують виїхати до країн ЕС. Для обох категорій респондентів окреслена майбутня поїздка не має постійного характеру, найчастіше опитані говорять про заплановане перебування за кордоном від трьох місяців до року (рис. 5).

Висновки. Таким чином, зворотна трудова міграція є актуальним та поширеним явищем для України та світу. У різних соціальних, історичних та географічних умовах це явище набуває різного змістовного забарвлення, що відображається у розмаїтті літературних джерел з цієї проблематики та низці теорій, що концептуалізують повернення мігрантів на батьківщину. Особливістю зворотної міграції в українських умовах є їі тимчасовий характер, оскільки велика частка поверненців мають наміри знову поїхати за кордон у майбутньому. Це свідчить про поширеність циркулярної міграції серед населення західних регіонів України, коли акт зворотної міграції слід розглядати не як остаточне фундаментальне рішення, а як певний етап у міграційних проектах населення, про що йдеться у дискурсі транснаціональної теорії міграції. Тимчасові повторювані виїзди за кордон хоча і $є$ більш вигідними для нашої держави з огляду на іiі соціально-економічний та демографічний розвиток, однак також містять низку загроз, зокрема для демографічної безпеки держави через зменшення чисельності населення, оскільки в результаті кожного наступного за черговістю виїзду за кордон мінімум кожен двадцятий мігрант може залишитися там назавжди та в подальшому перевезти туди свою родину.

Причинами виїзду за кордон є переважно трудові чинники, а сімейні фактори стимулюють повернення на батьківщину. Причини зворотної міграції з незначними варіаціями майже однакові для різних груп поверненців, незалежно від їхнього віку, статі, типу поселення тощо.

Визначення основних мотивів зворотної міграції українців, що лежать переважно у сфері сімейних стосунків, можуть мати цінність для розробки Україною плану заходів із заохочення повернення наших співвітчизників. У таких умовах покращання доступу до якісної освіти різних рівнів, охорони здоров'я, дозвілля для дітей слугують не лише фактором розбудови соціальної сфери для всього населення, а є ще й потужним непрямим механізмом міграційної політики у сфері заохочення повернення, недопущення трансформації тимчасової трудової міграції у іiї постійну незворотну форму. Мігранти, які будуть бачити, що їхні діти зростають на батьківщині у сприятливому оточенні, з меншою вірогідністю будуть вивозити їх із собою за кордон, що, у свою чергу, забезпечуватиме зворотність міграційних поїздок. Не заперечуючи важливості непрямих методів впливу, державі, звичайно, не слід нехтувати першопричинами міграцій. Потрібно здійснювати розбудову економічної 
сфери, покращувати можливості працевлаштування на регіональних ринках праці, сприяти зростанню заробітної плати, поліпшувати умови праці та дотримання трудового законодавства.

\section{ЛІТЕРАТУРА}

1. Sandu D. Remittances as Home Orientation Rooted in the Lifeworlds of Immigrants // Central and Eastern European Migration Review. - 2016 July 29. - P. 1-19 [Електронний ресурс]. - Режим доступу: https://www.researchgate.net/publication/305719238_Remittances_as_Home_Orientation_Rooted_in_the_Lifeworlds_of_Immigrants (дата звернення: 20.12.2018).

2. Anwar M. The Myth of Return: Pakistanis in Britain. - London: Heinemann Educational Books, 1979. $-278 \mathrm{p}$.

3. Zetter R. Reconceptualizing the Myth of Return: Continuity and Transition Amongst the GreekCypriot Refugees of 1974 // Journal of Refugee Studies. - Vol. 12, Iss. 1. - P. 1-22 [Електронний pecypc]. - Режим доступу: https://academic.oup.com/jrs/article-abstract/12/1/1/1599932 (дата звернення: 20.12.2018).

4. Cassarino J.-P. Theorising return migration: The conceptual approach to return migrants revisited // International Journal on Multicultural Societies (IJMS), UNESCO, 2004, 6(2), P. 253-279 [Електронний ресурс]. - Режим доступу: https://hal.archives-ouvertes.fr/hal-01237439/document (дата звернення: 20.12.2018).

5. Майданік І.П. Сучасні риси висококваліфікованої міграції в Україні та світі: основні тенденції та структура // Україна: аспекти праці. - 2018. - № 2. - С. 43-49.

6. Малиновська O.A. Еміграція vs Імміграція: напрями та механізми політики репатріації // Демографія та соціальна економіка. - 2019. - № 1 (35). - С. 69-81. - https://doi.org/10.15407/dse2019.01 .069

7. Позняк О.В. Зворотня міграція до України: обсяг і характеристики поверненців // Демографія та соціальна економіка. - 2019. - № 1 (35). - С. 82-96. - https://doi.org/10.15407/dse2019.01.082

\section{REFERENCES}

1. Sandu, D. (2016). Remittances as Home Orientation Rooted in the Lifeworlds of Immigrants. Central and Eastern European Migration Review, 1-19. Retrieved from https://www.researchgate.net/publication/305719238_Remittances_as_Home_Orientation_Rooted_in_the_Lifeworlds_of_Immigrants

2. Anwar, M. (1979). The Myth of Return: Pakistanis in Britain. London: Heinemann Educational Books.

3. Zetter, R. (1999). Reconceptualizing the Myth of Return: Continuity and Transition Amongst the Greek-Cypriot Refugees of 1974. Journal of Refugee Studies, 12 (1), 1-22. Retrieved from https://academic. oup.com/jrs/article-abstract/12/1/1/1599932

4. Cassarino, J.-P. (2004). Theorising return migration: The conceptual approach to return migrants revisited. International Journal on Multicultural Societies (IJMS), UNESCO 2004, 6 (2), 253-279. Retrieved from: https://hal.archives-ouvertes.fr/hal-01237439/document

5. Maidanik, I.P. (2018). Suchasni rysy vysokokvalifikovanoi mihratsii v Ukraini ta sviti: osnovni tendentsii ta struktura [Contemporary features of highly skilled migration in Ukraine and in the world: main trends and structure]. Ukraina: aspekty pratsi - Ukraine: labor aspects, 2, 43-49 [in Ukrainian].

6. Malynovs'ka, O.A. (2019). Emihratsiia vs Immihratsiia: napriamy ta mekhanizmy polityky repatriatsii [Emigration vs Immigration: directions and mechanisms of repatriation policy]. Demohrafiia ta sotsial'na ekonomika - Demography and social economy, 1 (35), 69-81. - https://doi.org/10.15407/dse2019.01.069 [in Ukrainian].

7. Pozniak, O.V. (2019). Zvorotnia mihratsiia do Ukrainy: obsiah i kharakterystyky povernentsiv [Return migration to Ukraine: scales and characteristics of returnees]. Demohrafiia ta sotsial'na ekonomika - Demography and social economy, 1 (35), 82-96. - https://doi.org/10.15407/dse2019.01.082 [in Ukrainian].

Стаття надійшла до редакції журналу 22.03.2019. 


\section{СОЦІАЛЬНО-ЕКОНОМІЧНІ ПРОБЛЕМИ}

https://doi.org/10.15407/dse2019.02.096

UDC 330.3(339)

JEL CLASSIFICATION: E 62, O 11

\section{I.G. MANTSUROV}

Dr. Sc. (Economics), Prof., Corresponding Member

of the National Academy of Sciences of Ukraine

Director General of the Research Institute

for System Statistical Studies

04053, Ukraine, Kyiv, Lvivska square, 14

E-mail: imantsurov@gmail.com

ORCID 0000-0003-1753-0422

\section{Y.V. KHRAPUNOVA}

PhD (Economics), Docent of Statistical Department

SHEI "Kyiv National Economic University

named after Vadym Hetman"

04053, Ukraine, Kyiv, Lvivska square, 14

E-mail: yakhrapunova@gmail.com

ORCID 0000-0002-6311-3235

\section{STATISTICAL MEASUREMENT OF THE INCLUSIVE GROWTH CHARACTERISTICS IN UKRAINE}

The article is devoted to the analysis of the inclusive economic growth and development overall concept, which represents an extremely important, however, overly overdue attempt to establish a link between economic growth and distribution among people and social groups that has to contribute in achieving the future generations' vital interests. The purpose of the article is to measure the inclusive growth's quantitative and qualitative characteristics in Ukraine as well as to define their compliance with the standards recommended by the well-known international organizations. It is proven that the inclusive growth is a potentially important contemporary agenda, but the issue is still to be resolved. In order to solve this task, the methodological basis needed for successful inclusive growth and development qualitative and quantitative measurement that has to show the role of governments in their efforts to reach significantly higher level of labor productivity and social equality as well as to save the environment. In the framework of this methodological approach, authors have improved the system of statistical indicators developed by the international organizations, in particular, by the OECD and WEF, and applied this system in order to measure the inclusive growth quantitative and qualitative characteristics in Ukraine. According to the analysis results that have been achieved, it is proved that the current model of economic behavior in Ukraine does not take into account the contemporary challenges, rules and regulations recommended by the international community. The main scientific results are presented as follows: the first section provides a brief history of the concept and its roots' evolution in the development policy contemporary scientific literature, the second section considers various definitions of the 'Inclusive Growth and Development' concept, the third section concludes with an evaluation of the concept and its qualitative and quantitative measurement on the basis of real Ukrainian statistical data.

(C) MANTSUROV I.G., KHRAPUNOVA Y.V., 2019 
The third section also provides the conceptual recommendations for improving the state economic policy and the Ukrainian Government's economic behavior.

Keywords: statistical measurement of the national economy characteristics, inclusive growth and development, economic dynamics and inclusive growth models of the government's economic behavior, improvement of the state economic policy.

\section{I.Г. Маниуров}

д-р екон. наук, проф., член-кор. НАН України

дир. Інституту системних статистичних досліджень

04053, Україна, м. Київ, Львівська площа, 14

E-mail: imantsurov@gmail.com

ORCID 0000-0003-1753-0422

\section{Я.В. Храпунова}

канд. екон. наук, доц. каф. статистики

ДВНЗ «Київський національний економічний

університет імені Вадима Гетьмана»

04053, Україна, м. Київ, Львівська площа, 14

E-mail: yakhrapunova@gmail.com

ORCID 0000-0002-6311-3235

\section{СТАТИСТИЧНЕ ВИМІРЮВАННЯ ХАРАКТЕРИСТИК ІНКЛЮЗИВНОГО ЗРОСТАННЯ В УКРАЇНІ}

Стаття присвячена аналізу загальної концепції всеосяжного економічного зростання і розвитку, що являє собою надзвичайно важливу, проте занадто запізнілу, спробу вчених установити зв'язок між економічним зростанням і розподілом між людьми та соціальними групами, яке має сприяти врахуванню життєво важливих інтересів майбутніх поколінь. Метою статті є вимірювання кількісних і якісних характеристик інклюзивного зростання в Україні, а також визначення їх відповідності стандартам, рекомендованим відомими міжнародними організаціями. Доведено, що інклюзивне зростання є потенційно важливим питанням нинішнього порядку денного, але комплексне рішення поставленої задачі ще не здійснено. Для вирішення цієї задачі в статті сформовано методологічні засади кількісного виміру інклюзивного зростання і розвитку, результати якого повинні показати роль урядів у їх зусиллях щодо досягнення значно вищого рівня продуктивності праці і соціальної рівності, а також збереження навколишнього середовища. У форматі цих методологічних засад автори вдосконалили систему статистичних показників, розроблену міжнародними організаціями, зокрема, ОЕСР $і$ ВЕФ, та використали ї для вимірювання кількісних і якісних характеристик інклюзивного зростання в Україні. За результатами аналізування доведено, що нинішня модель економічної поведінки в Україні не враховує сучасних викликів, правил і норм, рекомендованих міжннародним співтовариством. Основні наукові і практичні результати: у першому розділі статті викладено коротку історію концепиії та еволюції ї̈ теоретичних основ у сучасній науковій літературі; у другому розділі розглянуто різні визначення концепції «інклюзивного зростання і розвитку»; третій розділ завершується оцінкою концепції, ї̈ якісним та кількісним виміром, який здійснено на основі реальних статистичних даних про розвиток України; в останньому розділі представлено концептуальні рекомендащії щодо вдосконалення державної економічної політики, реалізація якої повинна призвести до поліпшення економічної поведінки Уряду України.

Ключові слова: статистичне вимірювання характеристик національної економіки, інклюзивне зростання та розвиток, економічна динаміка та моделі інклюзивного зростання, економічна поведінка урядів, поліпшення державної економічної політики.

\section{И.Г. Маниуров}

д-р экон. наук, проф., член-кор. НАН Украины

дир. Института системных статистических исследований

04053, Украина, г. Киев, Львовская площадь, 14

E-mail: imantsurov@gmail.com

ORCID 0000-0003-1753-0422 


\section{Я.В. Храпунова}

канд. экон. наук, доц. каф. статистики

ГВУЗ «Киевский национальный экономический

университет имени Вадима Гетьмана»

04053, Украина, г. Киев, Львовская площадь, 14

E-mail: yakhrapunova@gmail.com

ORCID 0000-0002-6311-3235

\section{СТАТИСТИЧЕСКОЕ ИЗМЕРЕНИЕ ХАРАКТЕРИСТИК ИНКЛЮЗИВНОГО РОСТА В УКРАИНЕ}

Статья посвящена анализу общей кониепции всеохватывающего экономического роста и развития, представляющей собой чрезвычайно важную, однако слишком запоздалую, попытку установить связь между экономическим ростом и распределением между людьми и социальными группами, который должен способствовать учету жизненно важных интересов будущих поколений. Цель статьи - измерение количественных и качественных характеристик инклюзивного роста в Украине, а также определение их соответствия стандартам, рекомендованным известными международными организациями. Доказано, что инклюзивный рост является потенциально важной повесткой дня, но комплексное решение задачи еще не осуществлено. Для решения этой задачи в статье сформулированы методологические основы количественного измерения инклюзивного роста и развития, результаты которого должны показать роль правительств в их усилиях по достижению значительно более высокого уровня производительности труда и социального равенства, а также по сохранению окружающей среды. $B$ формате этих методологических основ авторы усовершенствовали систему статистических показателей, разработанную международными организациями, в частности, ОЭСР и ВЭФ, и применили ее для измерения количественных и качественных характеристик инклюзивного роста в Украине. Согласно результатам анализа доказано, что нынешняя модель экономического поведения в Украине не учитывает современных вызовов, правил и норм, рекомендованных международным сообществом. Основные научные и практические результаты: в первом разделе изложена краткая история концепиии и эволюции ее теоретических основ в современной научной литературе; во втором разделе рассмотрень разные определения концепции «инклюзивного роста и развития»; третий раздел завершается оценкой концепции и ее качественным и количественным измерением, осуществленным на основе реальных статистических данных о развитии Украины; в последнем разделе содержатся кониептуальные рекомендации по совершенствованию государственной экономической политики, реализация которой призвана привести к улучшению экономического поведения Правительства Украины.

Ключевые слова: статистическое измерение характеристик национальной экономики, инклюзивный рост и развитие, экономическая динамика и модели инклюзивного роста, экономическое поведение правительств, совершенствование государственной экономической политики.

Introduction. The current stage of global economy development is characterized by a better understanding of theoretical concepts, aggravating the tensions and new global challenges, the increasing interaction of all participants and components of the world economic system. The globalization of the world economy creates a new environment for the countries' economic growth, defining new approaches to the formation of economic policy benchmarks of these countries.

One of those new approaches has been developed by the Organization for Economic Cooperation and Development (OECD) and adopted at the ministerial level during the OECD Council meeting in 2012. This approach recommended passing from the economic growth model of the state behavior to the so-called inclusive growth model.

Relevance of the paper. It should be noted that given the theoretical challenges, a new definition of the "Inclusive Growth and Development" has been provided by the authors. Taking into account the political challenges, has been proved that the continued desire for growth and the public perception that reducing the national debt should be a policy priority of governments. Given the challenges related to the qualitative and quantitative inclusive growth measurement, the improved statistical methodology has been provided and used in 
order to get the numerical characteristics of inclusive growth and development in Ukraine. It is particularly noteworthy that these characteristics and their qualitative interpretation have never been obtained in previous scientific research and publications.

Literature overview. Inclusive Growth is fast becoming a new national development policy concept. Its popularity has been driven, in large part, by two linked trends. The first is widespread concern about the scale and consequences of inequality and the dominant theoretical model has been provided in 1955 by the Kuznets S. [1] and improved during the last decade, particularly, by Benner, C. \& Pastor, M. [2], Douglass, C. [3], Cavanaugh, A. \& Breau, S. [4], Stiglitz, J. [5], and Summers, L. H. \& Balls, E. [6].

The second trend is the growing economic and political importance of economic growth and social development itself. In this context, Inclusive Growth has become one of the most fashionable concept in development policy among the policy-makers in the late 2000s and, as a result, was incorporated into the Sustainable Development Goals (United Nations,) and programs reports developed by the United Nations specialized agencies and other international organizations such as the OECD, World Bank, World Economic Forum (WEF), etc. [7-11].

More recently, there has been concern that economic growth was simply increasing inequality, without benefiting those with low income. A lot of Western scientists such as Atkinson, B. \& Bourguignon F. [12], Anand, R., Mishra, S., Peiris, S.J. [13], McConnell \& Brue, S. [14], Piketty, T. [15], Ranieri R. \& Ramos, A.R. [16], Shearer, C. \& Berube, A. [17] also provided numerous publications dedicated to these issues.

One common feature of many institutional definitions is that they highlight not just the importance of Inclusive Growth but also suggest that by making growth inclusive it will reach untapped sections of the economy and so increase overall output.

Several studies have tried to measure numerically the Inclusive Growth and Development. The Brookings Institution, for instance, has defined it statistically as three things: 1) the overall size of the economy - measured through jobs, new firms and output; 2) a measure of prosperity - productivity, average wages or standard of living; and 3) some indicator of narrowing economic disparity - either 'general' with employment, middle-class wages, working poverty or 'racial' - outcomes for whites and people of color and disparities between different groups.

In the end, success for Inclusive Growth and Development as a policy agenda may not be in the new policies and frameworks, but in the way existing programs and policies are reconfigured to consider distributional considerations.

Growing scientific interests in the search for a model for the development of socio-economic systems that will meet the principles of sustainable development and inclusive growth has been manifested in the increasing number of publications by such foreign scientists as D. Acemoglu, D. Robinson, E. Rinette, J. Stiglitz, S. Hollander, R. Boling, S. Podesta, C. Bedos, E. Duflou, M. Todaro and other researchers.

Among scientists from ex-Soviet Union counties, particularly from Ukraine, mention should be made of the scientific works of A. Amosha, V. Anisimova, A. Bazilyk, V. Vishnevsky, V. Granatourova, V. Heyets, E. Libanova, O. Lugina, I. Mantsurov, N. Nureev, A. Sidorova, etc. [18-21].

Summarizing the results of studies of foreign and Ukrainian scientists, it can be concluded that in the relevant publications, inclusive and extensional development models are considered, their features are described in different countries, although insufficient attention is paid to scrupulous analysis of each of the mentioned models. 
The purpose of the article is to measure the inclusive growth and development quantitative and qualitative characteristics in Ukraine as well as to define their compliance with the standards recommended by the well-known international organizations such as the OECD and the World Economic Forum.

Formulation of the problem and the article's novelty is to present to the international scientific and expert community the result of the inclusive growth statistical characteristics of Ukraine measurement and interpretation that never has been done previously in recent research and publications.

Methods and data. As has been mentioned above, in order to measure the inclusive growth quantitative and qualitative characteristics in Ukraine the methodology developed by the WEF in 2017-2018 was applied. According to this methodology, the WEF's Inclusive Development Index (IDI) ranks the world's advanced and developing economies based on their performance against key performance indicators ranging from poverty, inequality to public debt and environmental factors.

The IDI is an annual assessment of 103 countries' economic performance that measures how countries perform on eleven dimensions of economic progress in addition to GDP. It has 3 pillars; growth and development; inclusion and; intergenerational equity - sustainable stewardship of natural and financial resources.

The IDI is a project of the World Economic Forum's System Initiative on the Future of Economic Progress, which aims to inform and enable sustained and inclusive economic progress through deepened public-private cooperation through thought leadership and analysis, strategic dialogue and concrete cooperation, including by accelerating social impact through corporate action.

According the WEF's methodology, in contrast to the traditional measure of economic growth - a country's gross domestic product - the WEF's Inclusive Growth and Development Index is designed to capture other economic indicators, such as poverty levels, life expectancy, public debt, median income, wealth inequality and even damage to health and the environment caused by pollution. All these economic indicators are divided in three groups (See Fig.1). In order to average the values of these indicators, the WEF proposes to use the principal component analysis (PCA) statistical method.

Following these conceptual recommendations, authors applied PCA methodology on the basis of real statistical data provided by WEF (Tables 1\&2), the Ukrstat and the National Bank of Ukraine (NBU) (Fig. 2).

Main results of the research. The term inclusive growth in the interpretation of the OECD implies understanding that the welfare of society is not only the growth of real GDP and material incomes of the population, it's also a multi-vector concept that includes such spheres of a person's life as education, health-care, personal safety, ecology, and many others. Authors take into account the fact that one parameter of "sustainability" for economic growth is not enough. As a result, growth should be inclusive, that is, it should positively affect the well-being of the widest possible groups of population and simultaneously contributes to the nature environment preservation.

The main statistical characteristic developed for the measurement of the inclusive growth essence in one or another country is named as the Inclusive Growth and Development Index (IDI). It was proposed at the World Economic Forum in Davos in 2017 - as an alternative indicator to GDP per capita. This composite or, by other words, aggregate indicator is proposed to be used for a general estimation of the country's economic development state. At the same time, the indicator GDP per capita is considered as one of the components in the calculation of the IDI. 


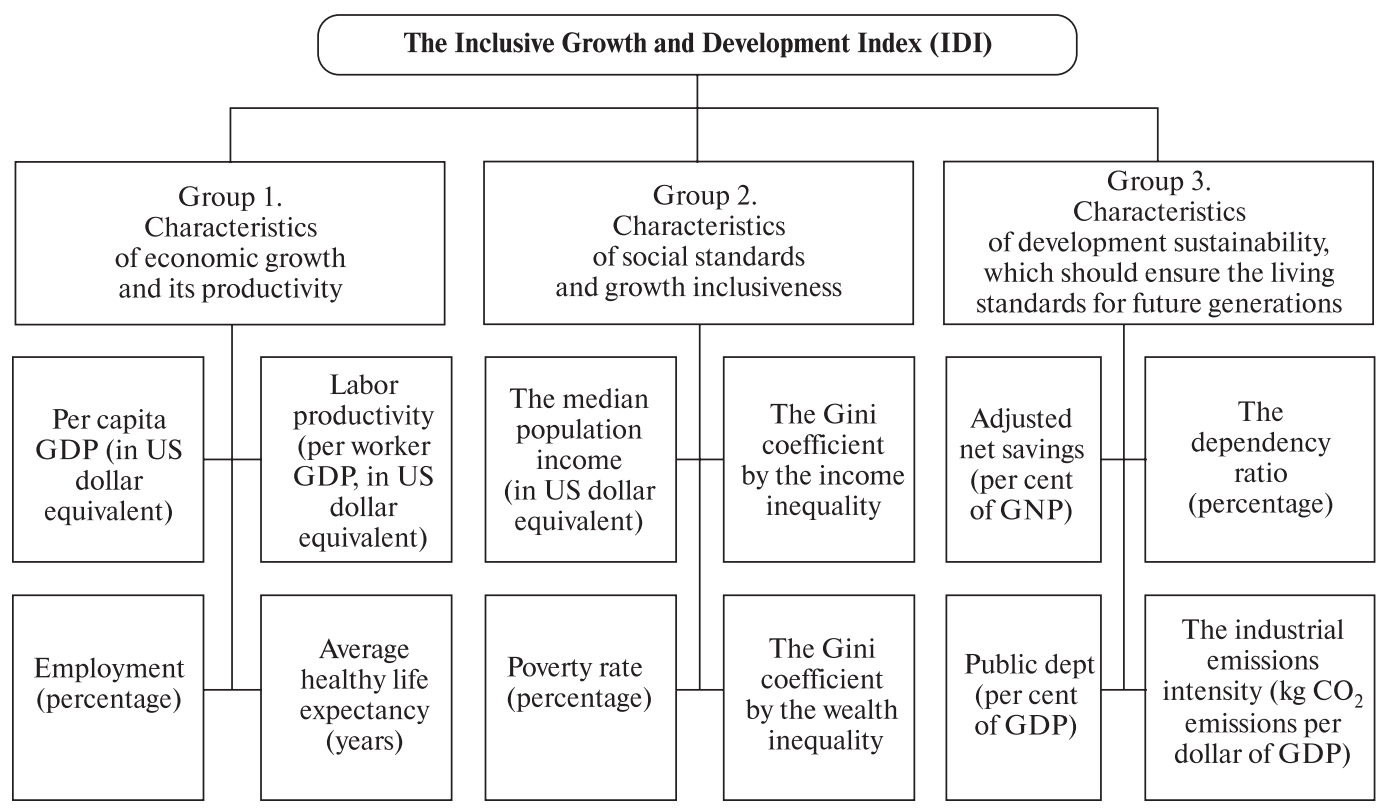

Fig. 1. Inclusive growth scorecard

Source: developed by the authors.

According to the WEF methodology, the Inclusive Growth and Development Index averages the values of 12 individual indicators of the country's development, which are distinguished into three groups. Each of these groups combines the characteristics of the state of the economy, the environment, and the country's social behavior model.

For the calculation of the values of the three group indicators (let's call them partial indicators of inclusiveness), that is, to average the values of the Key Performance Indicators, the WEF proposes to use the principal component analysis (PCA) method, according to which partial indicators - components $\mathrm{Gj}$ - are determined based on their ties with individual (primary) indicators:

$$
z_{i}=\sum_{1}^{m} a_{i j} G_{j}
$$

where $Z_{i}$ - standardized values of i-indicator; $a_{i j}$ - factor influence of $j$-component on $i$ indicator, which evaluates correlation level between them.

Taking into account that the principal component analysis is a statistical procedure that converts a set of observations of correlated variables into a set of values of uncorrelated variables called principal components, the Inclusive Growth and Development Index is summarizing values of three partial indices $G_{j}$ that belong to Groups 1, 2 and 3 (see Fig. 1 above) as an average arithmetic value.

In 2018, the World Economic Forum analyzed the inclusiveness of the development of 103 countries, among which 28 countries belong to the group of developed countries, and thus, 75 belong to the group of developing countries, among which, as is known, also is Ukraine [22].

According to the results of this study, among the developed countries in terms of the inclusiveness of economic growth, the top-five group includes Norway, Iceland, Luxembourg, Switzerland and Denmark. 
The group of developing countries was led by Lithuania, Hungary, Azerbaijan, Latvia and Poland.

As it was mentioned above, Ukraine, according to the classification of the World Bank, belongs to the group of developing countries. Among these countries, Ukraine ranks $49^{\text {th }}$ in terms of the inclusiveness of the economy, and thus, $78^{\text {th }}$ out of 103 countries whose development characteristics were examined this year by a team of experts of the World Economic Forum.

Turkey ranked 16 th in the same group, Russian Federation $-19^{\text {th }}$, Moldova $-31^{\text {st }}$. Honduras, Pakistan, Tanzania are ranked before Ukraine. Ukraine is followed only by Jordan, Kyrgyzstan, Ghana and Cameroon. In terms of the total score, Ukraine is the worst among all European countries.

It should be mentioned that 52 of the 103 countries that calculate the IDI recorded a decrease in the level of inclusive development over the past 5 years. This indicates the validity of the concern of the world scientific and expert community, which was expressed, in particular, at the World Economic Forum.

In 42 per cent of countries, the IDI has decreased quite significantly - even though the growth in per capita GDP. According to the results of their own calculation, the authors explain this by the fact that in $75 \%$ of countries where a decrease in the IDI was recorded, the level of wealth inequality significantly increased, which is measured using the Gini coefficient. The results of the calculations are presented in Table 1.

Ukraine, as mentioned above, takes $49^{\text {th }}$ place in the ranking of developing countries in 2018. It is much worth than in 2013, when the country occupied 41 positions in the same ranking.

This means that the percentage of Ukrainians, whose standard of living corresponds to their personal contribution to the process of economic growth, has decreased significantly. It's also necessary to bear in mind that Ukraine tops the list of countries in which a decrease in the level of inclusivity in 2013-2017 was recorded.

On the basis of the analysis of the values of individual indicators, which may be divided into indicators stimulator and destimulator, it's possible to draw the conclusions: the extremely low level of the index in Ukraine is shaped by a number of reasons.

Table 1. The IDI dynamics and the ranking of the leading countries in the relevant international distribution, period 2013-2017

\begin{tabular}{|c|c|c|c|}
\hline \multicolumn{2}{|c|}{ Group of developed countries } & \multicolumn{2}{|c|}{ Group of developing countries } \\
\hline $\begin{array}{l}\text { Rating of the top } 5 \\
\text { countries in the intern- } \\
\text { ational distribution by } \\
\text { inclusive growth in } 2018 \\
\text { and IDI value }\end{array}$ & $\begin{array}{c}\text { Ranking of the top } 5 \\
\text { countries by rate of in- } \\
\text { crease of growth inclu- } \\
\text { siveness in } 2013-2017 \text {, } \\
(\%)\end{array}$ & $\begin{array}{l}\text { Rating of the top } 5 \text { cou- } \\
\text { ntries in the distribution } \\
\text { according IDI's levels in } \\
2018 \text { and IDI value }\end{array}$ & $\begin{array}{c}\text { Ranking of the top } 5 \\
\text { countries by rate of in- } \\
\text { crease of growth inclu- } \\
\text { siveness in 2013-2017, } \\
(\%)\end{array}$ \\
\hline 1. Norway $(6,08)$ & 1. Iceland $(12,58)$ & 1. Lithuania $(4,86)$ & $\begin{array}{l}\text { 1. Republic of Northern } \\
\text { Macedonia }(9,24)\end{array}$ \\
\hline 2. Iceland $(6,07)$ & 2. Ireland $(9,28)$ & 2. Hungary $(4,74)$ & 2. Latvia $(8,60)$ \\
\hline 3. Luxembourg $(6,07)$ & 3. Denmark $(4,76)$ & 3. Azerbaijan $(4,69)$ & 3. Hungary $(8,10)$ \\
\hline 4. Switzerland $(6,05)$ & 4. Israel $(3,57)$ & 4. Latvia $(4,67)$ & 4. Panama $(4,80)$ \\
\hline 5. Denmark $(5,81)$ & 5. Czech Rep. $(2,88)$ & 5. Poland $(4,61)$ & 5. Romania $(4,21)$ \\
\hline
\end{tabular}

Source: developed by the authors and calculated according to the World Economic Forum data. 
Table 2. The IDI dynamics and the ranking of the leading countries in the relevant international distribution, period 2013-2017

\begin{tabular}{|l|c|l|c|}
\hline \multicolumn{2}{|c|}{ Group of developed countries } & \multicolumn{2}{c|}{ Group of developing countries } \\
\hline $\begin{array}{c}\text { Rating of the top 5 } \\
\text { countries that demonst- } \\
\text { rate the most significant } \\
\text { pace of decline of IDI } \\
\text { and its value in 2017 }\end{array}$ & $\begin{array}{c}\text { IDI decline rate in } \\
\mathbf{2 0 1 3}-\mathbf{2 0 1 8}, \mathbf{( \% )}\end{array}$ & $\begin{array}{c}\text { Rating of the top 5 } \\
\text { countries that demonst- } \\
\text { rate the most significant } \\
\text { pace of decline of IDI } \\
\text { and its value in 2017 }\end{array}$ & $\begin{array}{c}\text { IDI decline rate in } \\
\mathbf{2 0 1 3}-\mathbf{2 0 1 8 , ( \% )}\end{array}$ \\
\hline 11. Finland $(5,33)$ & $-2,92$ & 49. Ukraine $(3,42)$ & $-6,80$ \\
\hline 19. Slovenia (4,93) & $-2,39$ & 60. Mali $(3,10)$ & $-5,71$ \\
\hline 26. Spain $(4,40)$ & $-2,12$ & 66. Mauritania $(3,00)$ & $-5,12$ \\
\hline 28. Portugal $(3,97)$ & $-1,42$ & 41. Bolivia $(3,76)$ & $-3,80$ \\
\hline 10. Austria $(5,35)$ & $-0,17$ & 53. Cameroon $(3,32)$ & $-2,78$ \\
\hline
\end{tabular}

Source: developed by the authors and calculated according to the World Economic Forum data.

As is known, individual indicators the increase of which positively affects the level of a composite indicator are called stimulators. And indicators the value of which affects the generalized level of a composite indicator with a negative sign are called destimulators.

Sometimes, in order to bring indicators stimulators and indicators destimulators into a single framework, the latter are calculated as inverse, or its values are taken with a negative sign.

In the system of 12 individual indicators by which the growth inclusiveness is measured there are six indicator stimulators, while the rest are destimulators.

The first group should include GDP per capita, labor productivity, employment, average healthy life expectancy, the median population income, and volume of adjusted net savings.

The second group should include the Gini coefficient by the income inequality, poverty rate, the Gini coefficient by the wealth inequality, the dependency ratio, public debt, and the industrial emissions intensity.

It should be pointed out that among macroeconomic indicators-stimulators, three, namely - GDP per capita, labor productivity, volume of adjusted net savings - have values that are well below not only the levels that are characteristic of the leading states in the developing countries group, but also average values relevant indicators of this group of countries. Moreover, analyzing the temporal change in these indicators, it should be emphasized that over the last five years, a continuing annual decrease in the values of all indicators stimulators can be traced.

For example, in 2017 the volume of GDP per capita in Ukraine was only \$2,905, while in 2013 the level of this indicator was much higher, namely, \$41,845. To understand how low, the value of this important macroeconomic indicator is, it's enough to compare it with indicators of other countries. And if it makes no sense to compare the indicator of Ukraine with that of, for example, Luxembourg $(11,1001)$, Norway $(89818)$ or Switzerland $(\$ 75,726$ per capita GDP), then the comparison with other post-Soviet states is entirely correct.

And the results of this comparison are also stacked against Ukraine. So, in 2017, the level of GDP per capita in Kazakhstan was \$ 10,570, in the Russian Federation - \$11,099, in Belarus $-\$ 7,525$. Thus, today Ukraine is situated in last place among European countries by indicator of "GDP per capita". 
The same might be said about the value of the labor productivity indicator, which during 2013-2017 has decrease with an average annual decrease rate of $7.8 \%$.

By the rate of employment, which is equal to $53 \%$, the country is also at a relatively low $51^{\text {st }}$ position. The unemployment rate, that is, the inverse of the employment rate quantitative indicator, which is defined as the ratio of the number of unemployed to the total number of economically active population, over the last five years in Ukraine has decreased by $0,3 \%$. In September 2013, in Ukraine, the unemployed made up 1,5\% of the total number of working-age population, and now they make up only $1,2 \%$. The highest unemployment rate in the last 4 years was in 2014: at the time 1,6\% of Ukrainian working age citizens officially remained unemployed. Starting in 2015, the rate of unemployed has demonstrated a trend to decrease.

It should also be added that in December 2017, in terms of the contents of the labor market with vacancies, Ukraine regressed to approximately the 2014 year figures.

This would help to reduce the IDI from 3.42 to 3.33 , which, in turn, would also lead to a dip in Ukraine's ranking position in the international distribution of developing countries from $44^{\text {th }}$ to $53^{\text {rd }}$, and, consequently, to $82^{\text {nd }}$ position from 103 countries that WEF experts have included in the rating by IDI values.

Deepening the horizons of the analysis, the authors conclude that the main reason for the relatively low values of macroeconomic indicator stimulators and the negative dynamics of these values is the ultra-low adjusted net savings volume, which in Ukraine is equal to $1 \%$ only (unprecedented case), while for the group of developed countries the average value is $19 \%$, and in the group of developing countries is $11 \%$.

The basis for such a conclusion is the result of a correlation and regressive analysis of GDP per capita, labor productivity and employment, on the one hand, and net savings level, on the other.

In the first case, the coefficient of determination is equal to 0.87 , in the second case - to 0.83 , in the third - to 0.78 . This indicates that $87 \%$ of the variation in GDP per capita, and, consequently, $83 \%$ of the variation in labor productivity and $78 \%$ of the variation in the level of employment depends on the variation in the values of the net savings volume.

The situation is no better with the dynamics of values of indicator destimulators. In particular, in terms of social fragmentation by wealth inequality, Ukraine is in one of the last positions in the group of developing countries. The corresponding value of the Gini coefficient is $90.1 \%$, which puts Ukraine at $73^{\text {rd }}$ position from 79 developing countries. This indicates that wealth which is strongly concentrated in a few families doesn't work to develop production and doesn't generate sufficient incomes for the general public, which contributes to the growth of income inequality and, as a result, reduces the inclusiveness of growth.

In terms of the sustainability level of development, the Ukraine economy also demonstrates one of the worst indicators, ranking 75 in total from 79 countries.

In terms of public debt, both in absolute and in percent of GDP, Ukraine is in the middle of a variation row of a corresponding countries distribution. It is worth noting, however, that by the public debt volume growth rate in percentage to GDP, Ukraine ranks first among 103 countries of the world. Over the last five years, the value of this macroeconomic indicator has increased by $43 \%$.

Another theoretical and practical interest is paid to the analysis of the effect of population pressure on the volume of adjusted net savings - to test Nathaniel Leff's hypothesis regarding the existence of a tight and fairly significant inverse correlation between the proportion of dependents (pensioners and minors) in the total employed population and the volume of net savings - and, as a result, IDI's value. 


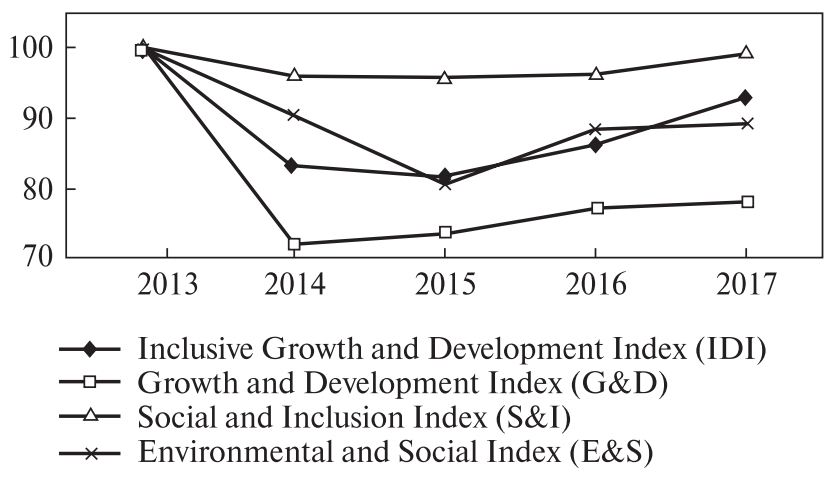

Fig. 2. Dynamics of the IDI components of Ukraine in 2013-2017

Source: developed by the authors on the basis of data provided by the Ukrstat and NBU.

According to the results of the correlation analysis, it must be acknowledged that the values of the coefficients of determination and verification criteria for testing the relationship to materiality (importance) give reason to confirm the hypothesis formulated by Nathaniel Leff.

The dynamics of the values of the three partial indices and the aggregated IDI's value of the Ukraine economy throughout 2013-2017 are graphically presented in Figure 2. The histograms presented on the graph characterize the chain-growth rates of IDI and its three components.

The form of all four histograms indicates that the characteristics of both economic growth and social standards and sustainable development, having decreased significantly in 2014, haven't yet restored the earlier indices. The set of averaged characteristics for the three indicators shapes the specific form of the fourth histogram, which combines the points characteristic of the IDI synthesis levels for 2013-2017.

\section{Conclusions.}

1. The concept of inclusive growth arose from the fact that GDP growth cannot be the sole criterion for determining the effectiveness of the development of national economies, which is more fully measured by the system of indicators proposed at the last World Economic Forum.

2. The principal indicator of this system is the Inclusive Growth and Development Index (IDI), which is considered as an alternative indicator to per capita GDP.

3. The use of the Inclusive Growth and Development Index is expedient not instead, but in addition to per capita GDP, since IDI is an abstract indicator, while per capita GDP is a real and widely understood indicator that has a clear interpretation.

4. Based on the analysis of the deviations of the actual values of the partial and integral indicators of compliance with the sustainable inclusive growth standards and the estimation of the threat of a crisis situation from the threshold levels, it was determined that during the years 2013-2017 the state of the Ukraine economy and its components deteriorated significantly. In 2017, as compared to 2013, the integral inclusiveness index value deteriorated by 6,8 points. This indicates the increasing impact of destabilizing factors and the developing of supercritical, with a pathological feature, state of the Ukraine economy.

5 . It has been proven that the negative impact of inadequate volume of domestic and foreign investment on the economy development is increasing, as evidenced by the extremely low value of adjusted net savings value (only $1 \%$ ). The resurgence of the investment 
volumes in fixed capital that would correspond to the volumes of the pre-crisis years - for the period of 2014-2017 - hasn't been achieved. In turn, this significantly limits the opportunities for economic growth and increases the level of threat of a permanently deepening economic crisis.

6. To lift the national economy's level, it's necessary to increase the share of investments in GDP value at least to the level common to developed countries, i. e., to $25-30 \%$. Only under such conditions the opportunities for the functioning of expanded reproduction can be created. In rapidly developing countries, the share of investment in GDP is up to $40 \%$ - as, for example, in China, where the last 30 years have passed under the banner of annual GDP growth of $10 \%$ on average.

7. Thus, the strategic priorities for the functional components of the inclusive growth index are as follows: elimination of distortions in macroeconomic reproduction processes, which consists in ensuring optimal proportions between investments and consumption, streamlining the ratio between wage growth and labor productivity growth, the renewal and disposal rate of fixed assets; keeping inflation at a moderate level, prevention of deflationary processes; stimulation of domestic consumption through the mechanism of consumer household demand growth, etc.

\section{LITERATURE}

1. Kuznets $S$. Economic growth and income inequality // American Economic Review. - 1955. 45 (1). - P. 1-28.

2. Benner C., Pastor M. Equity, growth, and community: What the nation can learn from America's metro areas. - Oakland: University of California Press, 2015. - https://doi.org/10.1525/luminos.6

3. Douglass $C$. North Institutions, institutional change and economic performance. - New York: Cambridge University Press, 1990. - $152 \mathrm{p}$.

4. Cavanaugh A., Breau S. Locating geographies of inequality: publication trends across OECD countries // Regional Studies. - 2017. - 52 (1). - P. 1-12. - https://doi.org/10.1080/ 00343404.2017.1371292

5. Стиглии Дж.Ю. Экономика государственного сектора. Пер. с англ. - М.: МГУ, ИНФРА, 1997. -639 c.

6. Summers L.H., Balls E. Report of the Commission on Inclusive Prosperity. Washington, DC: Center for American Progress, 2015. - 166 p. [Електронний ресурс]. - Режим доступу: https:// cdn.americanprogress.org/wp-content/uploads/2015/01/IPC-PDF-full.pdf (дата звернення: 22.03.2019).

7. G20 Group of Twenty (G20). Declaration of the leaders of the G20 St Petersburg Summit. - 2013. 28 р. [Електронний ресурс]. - Режим доступу: http://www.g20.utoronto.ca/2013/Saint_ Petersburg_Declaration_ENG.pdf (дата звернення: 22.03.2019).

8. National Accounts Statistics: Main Aggregates and Detailed Tables, 2015. - Part I-V - U.N., N.Y. [Електронний ресурс]. - Режим доступу: https://unstats.un.org/unsd/nationalaccount/madt.asp (дата звернення: 22.03.2019).

9. New Approaches to Economic Challenges. A Framework Paper / OECD. - Paris, 2012. [Електронний ресурс]. - Режим доступу: https://www.oecd.org/general/50452415.pdf (дата звернення: 22.03.2019).

10. New Approaches to Economic Challenges: A sustainable and inclusive growth agenda. Yearbook. - 2015. / OECD [Електронний pecypc]. - Режим доступу: http://www.oecd.org/ greengrowth/new-approaches-economic-challenges-sustainable-inclusive-growth-agenda.htm (дата звернення: 22.03.2019).

11. All on board: Making inclusive growth happen / OECD. - Paris, 2014. - https://doi.org/10.1787/ 9789264218512-en.

12. Kanbur R. Income distribution and development // Handbook of income distribution / Eds. Atkinson B., Bourguignon F. - Amsterdam: North-Holland, 2000. - Vol. 1. - P. 791-841 [Електронний 
pecypc]. - Режим доступу: https://EconPapers.repec.org/RePEc:eee:income:1 (дата звернення: 22.03.2019).

13. Anand R., Mishra S., Peiris S.J. Inclusive Growth Revisited: Measurement and Determinants / IMF Working Paper, 2013 [Електронний ресурс]. - Режим доступу: http://citeseerx.ist.psu.edu/ viewdoc/download?doi=10.1.1.692.342\&rep=rep1\&type=pdf (дата звернення: 22.03.2019).

14. Макконел К.Р., Брю С.Л. Экономика. Пер. с англ. - М.: Инфра-М, 2003. - 983 с.

15. Piketty T. Capital in the Twenty-First Century / Transl. by A. Goldhammer. - Cambridge, Massachusetts: Belknap Press of Harvard University, 2014. - 818 p.

16. Ranieri R., Ramos A.R. Inclusive growth: Building up a concept. Working Paper No. 104 / International Policy Centre for Inclusive Growth. - Washington, DC, 2013 [Електронний ресурс]. - Режим доступу: https://ideas.repec.org/p/ipc/wpaper/104.html (дата звернення: 22.03.2019).

17. Shearer $C$., Berube A. The Surprisingly Short List of US Metro Areas Achieving Inclusive Economic Growth // Brookings. The Avenue. - 2017 [Електронний ресурс]. - Режим доступу: https://www. brookings.edu/blog/the-avenue/2017/04/27/the-surprisingly-short-list-of-u-s-metro-areas-achievinginclusive-economic-growth/ (дата звернення: 22.03.2019).

18. КоваленкоД.В., Шалімова І.М., Керницький О.М. Конфліктологія: навч. посіб. для вузів Укр. інж.-пед. акад. - Харків: Точка, 2012. - 221 с.

19. Манцуров I.Г., Сріна А.М., Мазуренко О.К. та ін. Макроекономічна статистика: підруч. для вищ. навч. закл. / За ред. д-ра екон. наук, проф. І.Г. Манцурова; Київ. нац. екон. ун-т. -Т. 1. - Київ, 2013. $-325 \mathrm{c}$.

20. Харазішвілі Ю.М., Дронь С.В. Прогнозування індикаторів, порогових значень та рівня економічної безпеки України у середньостроковій перспективі: аналіт. доп. / Нац. ін-т стратег. дослідж. - Київ, 2014. - 117 с.

21. Тимошенко О.В. Економічна безпека національної економіки в умовах глобалізації. - Київ: Наш Формат, 2016. - 384 c.

22. The Inclusive Development Index Summary and Data Highlights / World Economic Forum (Geneva, Switzerland). - 2018. - 14 p. [Електронний ресурc]. - Режим доступу: https://www.weforum. org/reports/the-inclusive-development-index-2018 (дата звернення: 22.03.2019).

\section{REFERENCES}

1. Kuznets, S. (1955). Economic growth and income inequality. American Economic Review, 45(1), 128.

2. Benner, C., \& Pastor, M. (2015). Equity, growth, and community: What the nation can learn from America's metro areas. Oakland: University of California Press. - https://doi.org/10.1525/luminos.6

3. Douglass, C. (1990). North Institutions, institutional change and economic performance. NY: Cambridge University Press.

4. Cavanaugh, A., \& Breau, S., (2017). Locating geographies of inequality: publication trends across OECD countries. Regional Studies, 52 (1), 1-12. - https://doi.org/10.1080/00343404.2017.1371292

5. Stiglitz Joseph, E. (1999). Jekonomika gosudarstvennogo sektora [Economics of the public sector]. Third edition. NY-London: W.W. Norton \& Company [in Russian].

6. Summers, L.H., \& Balls, E. (2015). Report of the Commission on Inclusive Prosperity. Washington, DC: Center for American Progress. Retrieved from https://cdn.americanprogress.org/wp-content/ uploads/2015/01/IPC-PDF-full.pdf

7. G20 Group of Twenty (G20). Declaration of the leaders of the G20 St Petersburg Summit. (2013). St. Petersburg: G20. Retrieved from http://www.g20.utoronto.ca/2013/Saint_Petersburg_ Declaration_ENG.pdf

8. National Accounts Statistics: Main Aggregates and Detailed Tables (2015). Part I-V. U.N., NY. Retrieved from https://unstats.un.org/unsd/nationalaccount/madt.asp

9. New Approaches to Economic Challenges (2012). A Framework Paper, OECD, Paris. Retrieved from https://www.oecd.org/general/50452415.pdf

10. New Approaches to Economic Challenges: A sustainable and inclusive growth agenda (2015). Retrieved from http://www.oecd.org/greengrowth/new-approaches-economic-challenges-sustainable-inclusivegrowth-agenda.htm 
11. All on board: Making inclusive growth happen (2014). Paris, OECD. - https://doi.org/10.1787/ 9789264218512-en

12. Kanbur, R. (2000). Income distribution and development. B. Atkinson, F. Bourguignon (Eds.). Handbook of income distribution, Vol. 1, 791-841. Retrieved from https://EconPapers.repec.org/RePEc:eee: income: 1

13. Anand, R., Mishra, S., \& Peiris, S.J. (2013). Inclusive Growth Revisited: Measurement and Determinants. IMF Working Paper. Retrieved from http://citeseerx.ist.psu.edu/viewdoc/download?doi=10.1.1.692. $342 \&$ rep $=$ rep $1 \&$ type $=$ pdf

14. McConnell, C.R., \& Brue, S.L. (2008). Economics [Economics]. (17th edition). NY: McGraw-Hill [in Russian].

15. Piketty, T. (2014). Capital in the Twenty-First Century. A. Goldhammer (Transl.). Cambridge, Massachusetts: Belknap Press of Harvard University.

16. Ranieri, R., \& Ramos, A.R. (2013). Inclusive growth: Building up a concept. Working Paper, 104. Washington, DC: International Policy Centre for Inclusive Growth. Retrieved from https://ideas.repec. org/p/ipc/wpaper/104.html

17. Shearer, C., \& Berube, A. (2017). The Surprisingly Short List of US Metro Areas Achieving Inclusive Economic Growth. Brookings. The Avenue. https://www.brookings.edu/blog/the-avenue/2017/04/27/ the-surprisingly-short-list-of-u-s-metro-areas-achieving-inclusive-economic-growth/

18. Kovalenko, D.V., Shalimova, I.M., \& Kernickij, O.M. (2012). Konfliktolohiia [Conflictology]. Ukr. engine.-ped. acad. Kharkiv: Tochka [in Ukrainian].

19. Mantsurov, I.G., Yerina, A.M., \& Mazurenko, O.K. et al. (2013). Makroekonomichna statistika, tom 1. Pidruchnyk dlya vyschyh navchalnyh zakladiv. [Macroeconomic statistics: manual higher educational institutios]. Kyiv [in Ukrainian].

20. Kharazishvili, Y.M., \& Dron, E.V. (2014). Prognozuvannya indikatoriv, porogovih znachen ta rivnya ekonomichnoyi bezpeki Ukrainy $v$ serednostrokoviyperspektyvi; analit. dop. [Forecasting of indicators, threshold values and level of economic security of Ukraine in the medium-term perspective: analytical report]. Kyiv [in Ukrainian].

21. Tymoshenko, O.V. (2016). Ekonomichna bezpeka natsionalnoyi ekonomiki v umovah globalizatsiyi. [Economic security of the national economy in globalization conditions]. Kyiv [in Ukrainian].

22.The Inclusive Development Index 2018. (2018). Summary and Data Highlights. World Economic Forum. Geneva, Switzeland. Retrieved from https://www.weforum.org/reports/the-inclusive-developmentindex-2018

Стаття надійшла до редакції журналу 22.03.2019. 


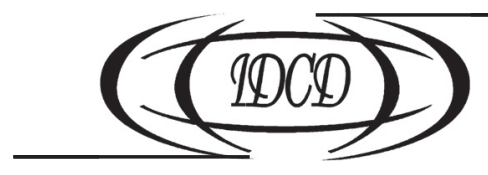

https://doi.org/10.15407/dse2019.02.109

УДК 316.776.4(477):33.025

JEL CLASSIFICATION: I 38, J 78, J 23

\title{
О.Ф. НОВIКОВА
}

Д-р екон. наук, проф., заст. директора

Інститут економіки промисловості НАН України

03057, Україна, м. Київ, вул. Марії Капніст, 2

E-mail: novikovaof9@gmail.com

ORCID 0000-0002-8263-1054

\section{Л.Л. ШАМІЛЕВА}

канд. екон. наук, пров. наук. співроб., доцент

Інститут економіки промисловості НАН України

03057, Україна, м. Київ, вул. Марії Капніст, 2

E-mail: larisashamileva2017@gmail.com

ORCID 0000-0003-4738-0728

\section{СОЦІАЛЬНА СПРАВЕДЛИВІСТЬ У ПРОЦЕСАХ ВИМУШЕНОГО ПЕРЕСЕЛЕННЯ: ОЦІНКА ТА ПРІОРИТЕТИ ДОСЯГНЕННЯ}

\begin{abstract}
Викладено результати наукових досліджень, спрямованих на розробку науково-методичного забезпечення кількісної оцінки рівнів прояву соціальної несправедливості по відношенню до внутрішньо переміщених осіб (ВПО) за окремими сферами. Мета дослідження - оцінка рівня прояву соціальної несправедливості щодо ВПО за основними сферами життєдіяльності за розробленою та апробованою авторською методикою. Систематизовано основні напрями прояву дискримінації з оцінкою рівнів за кожною складовою. Використано зрівняльний підхід із базової концепції соціальної справедливості, який визначає ступінь реалізації базових принципів соціальної справедливості в основних сферах життєзабезпечення ВПО та постійного населення. За розробленою та апробованою методикою оцінки рівня соціальної справедливості визначено, що захищеність матеріального добробуту ВПО на $29 \%$ нижче, ніж постійного населення, а рівень бідності серед ВПО на $72 \%$ вище, ніж постійного населення за критерієм депривації «змушені заощаджувати навіть на харчуванні». Рівень економічної захищеності на ринку праці на 30 \% нижче, ніж серед постійного населення, а рівень доступності ринку соціальних послуг для ВПО - на 33 \%. У ВПО на 22 \% менше можливості одержати медичні послуги, майже на 50 \% - придбати ліки, 22 \% ВПО констатують, що їм бракує коштів для оплати оренди житла та житлово-комунальних послуг. За самооцінкою 57 \% ВПО, рівень інтегрованості їх у територіальні громади нижчий, ніжк у постійного населення. Недостатнє забезпечення соціальної справедливості відносно переселенців відмітили $96 \%$ ВПО, цю ж оцінку щодо ВПО дало 88 \% постійного населення.
\end{abstract}

Ключові слова: соціальна справедливість, дискримінація, захищеність, соціальні ризики, інтегральний показник, внутрішньо переміщені особи, постійне населення.

(C) НОВІКОВА О.Ф., ШАМІЛЕВА Л.Л., 2019 
О.Ф. Новикова

д-р экон. наук, проф., зам. директора

Институт экономики промышленности НАН Украины

03057, Украина, г. Киев, ул. Марии Капнист, 2

E-mail: novikovaof9@gmail.com

ORCID 0000-0002-8263-1054;

\section{Л.Л. Шамилева}

канд. экон. наук, вед. наук. сотр., доцент

Институт экономики промышленности НАН Украины

03057, Украина, г. Киев, ул. Марии Капнист, 2

E-mail: larisashamileva2017@gmail.com

ORCID: 0000-0003-4738-0728

\section{СОЦИАЛЬНАЯ СПРАВЕДЛИВОСТЬ В ПРОЦЕССАХ ВЫНУЖДЕННОГО ПЕРЕСЕЛЕНИЯ: ОЦЕНКА И ПРИОРИТЕТЫ ДОСТИЖЕНИЯ}

Изложены результаты научного исследования по разработке научно-методического обеспечения количественной оценки степени проявления социальной несправедливости по отношению к внутренне перемещенным лицам (ВПЛ) в отдельных сферах. Цель статьи - оценка уровня проявления социальной несправедливости относительно ВПЛ по разработанной и апробированной авторской методике. Систематизированы основные направления проявления дискриминации с оценкой уровней по каждой составляющей. Использован сравнительный подход базовой концепщии социальной справедливости, определяющий степень реализации базовых принципов социальной справедливости в основных сферах жизнеобеспечения ВПЛ и постоянного населения. По апробированной методике оценки уровня социальной справедливости определено, что защищенность материального благосостояния ВПЛ на $29 \%$ ниже, чем постоянного населения, а уровень бедности среди ВПЛна 72 \% выше по критерию депривации «вынуждены экономить даже на питании». Уровень экономической защищенности на рынке труда на $30 \%$ ниже, чем среди постоянного населения, а уровень доступности рынка социальных услуг для ВПЛ - на $33 \%$. У ВПЛна 22 \% меньше возможность получить медицинские услуги, почти на $50 \%$ - приобрести лекарства, 22 \% ВПЛ констатируют, что им не хватает средств для оплаты аренды жилья и жилищно-коммунальных услуг. Согласно самооценке $57 \%$ ВПЛ, уровень их интегрированности в территориальные общины ниже, чем у постоянного населения. Недостаточное проявление социальной справедливости относительно переселенцев отметили 96 \% ВПЛ и 88 \% постоянного населения.

Ключевые слова: социальная справедливость, дискриминация, защищенность, социальные риски, интегральный показатель, внутренне перемещенные лица, постоянное население.

\section{O.F. Novikova}

Dr. Sc. (Economics), Prof., Deputy Director

Institute of Industrial Economics of the NAS of Ukraine

03057, Ukraine, Kyiv, Marii Kapnist Str., 2

E-mail: novikovaof9@gmail.com

ORCID 0000-0002-8263-1054

\section{L.L. Shamileva}

Ph.D. (Economics), Leading Researcher

Institute of Industrial Economics of the NAS of Ukraine

03057, Ukraine, Kyiv, Marii Kapnist Str., 2

E-mail: larisashamileva2017@gmail.com

ORCID 0000-0003-4738-0728

\section{SOCIAL JUSTICE IN THE PROCESSES OF FORCED RESETTLEMENT: EVALUATION AND PRIORITIES OF ACHIEVEMENT}

Innovative results of researches in the development of a methodical provision of quantitative assessment of the levels of social injustice in relation to IDPs in certain spheres are given. The purpose of the article is to assess the 
level of manifestation of social injustice regarding internally displaced persons according to the developed and tested author's methodology. The main directions of discrimination are ranked systematically, with the assessment of levels for each component. A comparative approach is used from the basic concept of social justice, which defines the degree of implementation of the basic principles of social justice in the main spheres of life support of IDPs and permanent population. According to the tried and tested method of assessing the level of social justice, it was determined that the security of material welfare of the IDPS is $29 \%$ lower than that of the permanent population, and the poverty rate among the IDPs is $72 \%$ higher than the permanent population by the criterion of deprivation "Forced to save even for food". The level of economic security in the labor market is $30 \%$ lower than in the permanent population, and the level of accessibility to the market of social services for IDPs is $33 \%$ lower than for the permanent population. In the IDPs, $22 \%$ less is the opportunity to receive medical services, almost $50 \%$ buy medicines, and $22 \%$ of IDPs state that there is insufficient funds to pay for rental housing and housing and communal services. According to the self-rating of $57 \%$ of the IDPs, the level of integration in the local communities is lower than that of the permanent population. Insufficient provision of social justice is cited by $96 \%$ of IDPs and by $88 \%$ of the permanent population. In general, the value of the integral indicator shows that the level of achievement of social justice in certain areas of its manifestation among the IDPs is $30.5 \%$ lower than among the resident population. Social justice in relation to the IDPs is determined by the excess of the level of poverty by 3.6 times than the permanent population. Every tenth migrant was forced to save even on food. Due to the lack of funds, IDPs are limited in the ability to get any profession, purchase medicines, pay rent and utility services. Among immigrants, there is a significantly higher level of unemployment, especially long-term, than among the resident population. Consequently, the existence of discrimination in relation to IDPs can be traced when the basic principles in social justice are violated, which are determined by the social justice index according to the EU methodology.

Keywords: social justice, discrimination, protection, social risks, integral indicator, internally displaced persons, permanent population.

Постановка проблеми та актуальність теми. Необхідність розробки методологічних засад вимірювання та науково-методичного забезпечення оцінки рівнів соціальної справедливості щодо внутрішньо переміщених осіб (ВПО) особливо актуальна нині у зв’язку з проявами дискримінації щодо них, а також через невизначеність пріоритетів державної політики з цих питань. Прагнення будь-якого суспільства до соціальної справедливості обумовлено потребами встановлення соціального порядку, подолання перешкод до гідного існування та встановлення певного балансу між ціннісними настановами людини та їх фактичною реалізацією. Шукати соціальну справедливість в умовах вимушеної міграції населення зі сходу України у зв’язку зі збройним конфліктом складно, але необхідно дати можливість переселеним громадянам України адресно відчути опіку держави, підтримку суспільства та міжнародної спільноти. За п’ять років переселення ситуація з ВПО значно змінилася. Спочатку була складна адаптація до нових умов життя без житла, роботи, доходів і з очікуванням швидкого повернення додому, потім - поступова інтеграція у громади і небажання повертатися назад. У червні 2018 р. 38 \% ВПО визначили, що не планують повертатися назад, а це на $10 \%$ більше ніж у 2017 році [1, 2]. Зневіреність у настанні миру, невизначеність із поверненням майна, що залишилось на окупованій території, звикання до труднощів переселенського життя, а також поступове успішне розв'язання проблем інтеграції у місця переселення обумовлюють посилення мотивації неповернення до Донбасу після завершення конфлікту. Але попри ці зміни у настроях, ВПО залишаються у несприятливих життєвих обставинах, вони дискриміновані у власній державі і через соціальну несправедливість, негативні переживання та стреси руйнують своє життя і здоров’я. Суспільство звикло до проблем переселенців, вони втратили свою гостроту, але досі залишились невирішеними. Тому нині постає питання вимірювання та оцінювання цих проблем з метою створення засад їх розв'язання, зокрема для посилення відчуття соціальної справедливості у ВПО. 
Аналіз останніх досліджень. Дослідження соціальної справедливості, яке об'єднує різні сфери життєдіяльності людини, обумовлює необхідність визначення кількісних та якісних показників іiі вимірювання, розробки інтегрального показника рівня соціальної справедливості. На сьогодні існує декілька підходів до цього. Найбільш відомий - обрахування Індексу соціальної справедливості (ICC), розробленого в Європейському Союзі, який щорічно обновлюють євроінституції [3].

ICC складається з шести вимірів: профілактика бідності, доступ до освіти, включення ринку праці, соціальна згуртованість та недискримінація, здоров'я, справедливість поміж поколіннями. Ці показники визначають на основі 30 кількісних та восьми якісних показників, кожен із яких пов'язаний з одним із шести вимірів соціальної справедливості.

Як опосередкований вимір соціальної справедливості на рівні окремих держав В. Жовновата (V. Zhovnovata) рекомендує застосовувати індекси людського розвитку, які за змістом охоплюють основні характеристики людського потенціалу [4, c. $20-31]$.

Ці інтегральні показники переважно розраховують на рівні держав та використовують для характеристики рівня ефективності соціальної політики держав на основі зіставлення безпосередньо показників, їхніх складових та рангів за ними.

Серед вітчизняних наукових напрацювань сьогодні відсутні наукові дослідження кількісного вимірювання рівнів соціальної справедливості як за сферами прояву, так і з використанням підсумкового показника для оцінки реалізації базових принципів соціальної справедливості щодо певних верств населення. В Україні доцільно застосовувати такі складові ICC - показник порушення бідності, якості політики в системі освіти, індекс доступності до ринку праці та підіндекс справедливості поміж поколіннями [4, с. 20-32].

Інший напрям визначення та вимірювання соціальної справедливості, пов’язаний з теорією виміру нерівностей, використовують Г.Ю. Міщук (G. Micshuk) i H.Н. Смолянюк (N. Smolianiuk). Мова йде про оцінку надмірної нерівності доходів, оплати праці, розподілу ресурсів, доступності певних видів соціальних послуг тощо $[5$, c. $58-72]$.

В. Новіков (V. Novikov) і В. Семенов (V. Semenov) [6] систематизують методичні підходи до визначення рівня соціальної справедливості, обгрунтовують переваги їх використання залежно від мети та ієрархічного рівня (суспільство, регіон) оцінки рівнів соціальної справедливості.

Новизна роботи полягає у теоретичному обгрунтуванні та розробці науковометодичного забезпечення оцінки рівня соціальної несправедливості щодо ВПО за сферами - захищеність матеріального добробуту, порушення принципів соціальної справедливості на ринку праці, доступність соціальних послуг та соціальне включення до громад. Уперше з урахуванням основних положень методики розрахунку ICC запропоновано здійснити оцінку рівнів соціальної справедливості за сферами життєдіяльності до окремої групи громадян - ВПО.

Мета статті - оцінити рівень прояву соціальної несправедливості щодо внутрішньо переміщених осіб за основними сферами життєдіяльності за розробленою та апробованою авторською методикою.

Методи дослідження. У статті використано економіко-статистичний метод для порівняльної оцінки рівня соціальної справедливості за складовими, математикостатистичний - для визначення інтегрального показника рівня соціальної справедливості щодо ВПО з оцінкою впливу його складових на відносну зміну. 
Виклад основного матеріалу. Соціальна несправедливість щодо ВПО визначена проявами дискримінації у зв'язку з їх новим статусом. Так, за результатами останніх трьох звітів Національної системи моніторингу, дискримінацію визначають близько 12-13\% переселенців [1, 7, 8]. Відчуття дискримінації або несправедливого ставлення пов’язано в першу чергу з припиненням соціальних виплат. Близько 18 \% домогосподарств серед ВПО повідомили, що зазнали призупинення соціальних виплат із початку конфлікту, при цьому за останні півтора роки цей показник зріс у 2,5 рази. Основні сфери, за якими переселенці відчували дискримінацію, стосувалися житла (від 46 до 65 \%), взаємодії з місцевим населенням (від 19 до $39 \%$ ) та зайнятості (від 19 до $31 \%$ ). Лише за рік, з червня 2017 р. до червня 2018 р. на 16 \% зросла частка ВПО, які відчувають дискримінацію у взаємодіях з місцевим населенням, але намітилась і позитивна тенденція, пов'язана зі зниженням несправедливості стосовно ВПО на ринку праці [1, 2, 7-9, 11-12].

Рівень дискримінації ВПО за різними напрямами порушення принципів соціальної справедливості можна виявити шляхом зіставлення відповідних індикаторів виміру для постійного населення та ВПО.

Виходячи з трьох базових концепцій соціальної справедливості (зрівняльна, розподільна та ліберальна) вибір для порівняння реалізації базових принципів соціальної справедливості в основних сферах життєзабезпечення серед ВПО та постійного населення був на стороні зрівняльного підходу. Основні положення цього підходу мають певні переваги, бо пов’язані з близькістю понять справедливість і рівність, а його кількісний критерій відповідає змісту арифметичної рівності. Основні принципи соціальної справедливості, зокрема рівність усіх громадян перед законом, забезпечення гарантій життєдіяльності та високий рівень соціального захисту передбачають рівні можливості як для постійного населення, так і для ВПО. Рівні можливості визначають за такими ознаками: забезпечення роботою кожного працездатного; гідна заробітна плата; соціальне забезпечення осіб з інвалідністю та дітей-сиріт; вільний доступ громадян до освіти, охорони здоров’я, культури та спорту; соціальне включення.

Для цих контингентів населення за умови повного втілення принципів соціальної справедливості повинні бути забезпечені рівні можливості доступу до матеріальних благ, гідної зайнятості відповідно до їх рівня професійної підготовки та кваліфікації, забезпечення рівних умов та рівня життя, доступності до всіх соціальних послуг, рівних умов доступу до прогресивної соціальної мобільності в суспільстві, відсутності дискримінації за статусом ВПО тощо. Вимір ступеня реалізації принципів соціальної справедливості для ВПО базується на зіставленні умов життєзабезпечення за окремими сферами для переселенців та постійного населення, де склалися та проявлені умови, що визначають порушення цих принципів та дискримінації ВПО.

В узагальненому вигляді інтегральний індекс забезпечення соціальної справедливості $\left(K_{\text {заб. сои. сnрп. }}\right)$ розраховується як середня геометрична з коефіцієнтів зіставлення рівнів соціально-економічної захищеності за наведеними складовими для постійного населення та ВПО (1). Виходячи з наявності статистичної інформації, на основі якої можна оцінити складові та зіставити рівні забезпечення соціальної справедливості та соціально-економічної захищеності, як базу порівняння обрано показники постійного населення, а інтегральний показник зіставлення рівнів забезпечення соціальної справедливості визначено за таким співвідношенням:

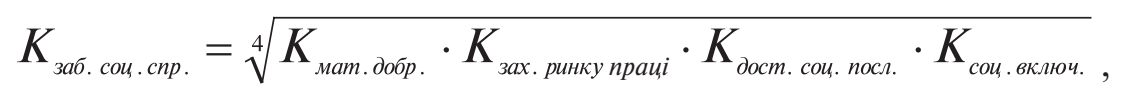


де $K_{i}$ - субіндекси співставлення рівнів захищеності, зокрема: $K_{\text {мат. добр. }}-$ захищеності матеріального добробуту; $K_{\text {зах. ринкупраці }}$ - захищеності на ринку праці; $K_{\text {дост. соц. посл. }}$ - доступності соціальних послуг; $K_{\text {соц. включ. }}$ - соціального включення.

Кожний субіндекс $\left(K_{i}\right)$ визначений за алгоритмом середньої геометричної з коефіцієнтів співвідношення відповідних індикаторів їх виміру (2):

$$
K_{i}=\sqrt[m_{i}]{k_{1} \cdot k_{2} \ldots k_{m_{i}}}=\sqrt[m_{i}]{\Pi_{j=1}^{m_{i}} \cdot k_{j}},
$$

де: $k_{j}$ - коефіцієнти зіставлення індикаторів $j$-го субіндексу; $j=\overline{1, m} 1 ; m_{j}-$ кількість індикаторів кожної $i$-ої складової; $i=\overline{1,4} ; k_{j}=X_{j \text { впо }} / X_{j \text { пост. нас. }} ; X_{\text {jпост. нас. }} ; X_{j \text { впо }}-$ значення $j$-го індикатора, відповідно, для постійного населення та ВПО ${ }^{1}$.

За визначеними та наведеними в таблиці показниками розраховані всі обрані для розрахунків коефіцієнти співвідношення рівнів соціальної та економічної захищеності $\left(k_{i}\right)$ для визначення рівнів соціальної справедливості всього населення та контингенту ВПО як за окремими субіндексами, так і в цілому за всіма її складовими.

Таблиия. Індикатори рівнів забезпечення соціальної справедливості постійного населення та ВПО за окремими її складовими

\begin{tabular}{|c|c|c|c|c|c|}
\hline \multirow[b]{2}{*}{ Індикатори } & \multirow[b]{2}{*}{$\boldsymbol{k}_{\boldsymbol{i}}$} & \multirow[b]{2}{*}{$\begin{array}{l}\text { Напрями } \\
\text { впливу }\end{array}$} & \multicolumn{2}{|c|}{ Рівень та значення } & \multirow[b]{2}{*}{$\begin{array}{c}\text { Коефіцієнт } \\
\text { співвідно- } \\
\text { шення } \\
k_{j}=X_{\text {јвпо }} \\
X_{j \text { јпст. нас. }}\end{array}$} \\
\hline & & & $\begin{array}{c}\text { для по- } \\
\text { стійного } \\
\text { населення } \\
\left(X_{i \text { пост. нас. }}\right)\end{array}$ & $\begin{array}{c}\text { для } \\
\text { ВПО за } \\
\text { раун- } \\
\text { дом } 9 \\
\left(X_{i \text { впо }}\right)\end{array}$ & \\
\hline \multicolumn{6}{|c|}{ I. Захищеність матеріального добробуту $\left(K_{\text {мат. добр. }}\right)$} \\
\hline $\begin{array}{l}\text { 1. Середній рівень доходів на одну } \\
\text { особу, грн. }\end{array}$ & $k_{1}$ & стимулятор & 3640 & 2239 & 0,6151 \\
\hline $\begin{array}{l}\text { 2. Питома вага заробітної плати як } \\
\text { основного джерела доходу, \% }\end{array}$ & $k_{2}$ & стимулятор & 52,4 & 63,0 & 1,202 \\
\hline $\begin{array}{l}\text { 3. Співвідношення середньомісяч- } \\
\text { ного доходу та фактичного прожит- } \\
\text { кового мінімуму ( } 3327 \text { грн) }\end{array}$ & $k_{3}$ & стимулятор & 1,094 & 0,673 & 0,615 \\
\hline \multicolumn{6}{|l|}{$\begin{array}{l}\text { 4. Рівень бідності за критеріями } \\
\text { депривації: }\end{array}$} \\
\hline $\begin{array}{l}\text { 4.1. Змушені заощаджувати на- } \\
\text { віть на харчуванні, \% }\end{array}$ & $\boldsymbol{k}_{4}$ & дестимулятор & 4,5 & 16,0 & 0,281 \\
\hline $\begin{array}{l}\text { 4.2. Коштів вистачає лише на } \\
\text { харчування }\end{array}$ & $\boldsymbol{k}_{5}$ & дестимулятор & 44,0 & 38,0 & 1,158 \\
\hline $\begin{array}{l}4.3 \text { Коштів вистачає на харчу- } \\
\text { вання, необхідний одяг, взуття, } \\
\text { нагальні потреби }\end{array}$ & $k_{6}$ & стимулятор & 45,7 & 40 & 0,875 \\
\hline
\end{tabular}

${ }^{1}$ Для зіставлення рівнів соціально-економічної захищеності або дискримінації, які проявляються в структурі постійного населення та ВПО, тут враховано тільки індикатори, зіставні для обох контингентів. 
Закінчення таблииі

\begin{tabular}{|c|c|c|c|c|c|}
\hline \multirow[b]{2}{*}{ Індикатори } & \multirow[b]{2}{*}{$\boldsymbol{k}_{\boldsymbol{i}}$} & \multirow[b]{2}{*}{$\begin{array}{l}\text { Напрями } \\
\text { впливу }\end{array}$} & \multicolumn{2}{|c|}{ Рівень та значення } & \multirow[b]{2}{*}{$\begin{array}{c}\text { Коефіцієнт } \\
\text { співвідно- } \\
\text { шення } \\
k_{j}=X_{\text {јвпо }} \\
/ X_{\text {јпост. нас. }}\end{array}$} \\
\hline & & & $\begin{array}{c}\text { для по- } \\
\text { стійного } \\
\text { населення } \\
\left(X_{i \text { пост. нас. }}\right)\end{array}$ & $\begin{array}{c}\text { для } \\
\text { ВПО за } \\
\text { раун- } \\
\text { дом } 9 \\
\left(X_{i \text { впо }}\right)\end{array}$ & \\
\hline \multicolumn{6}{|c|}{ II. Захищеність на ринку праці ( $\left.K_{\text {зах. ринку пращ })}\right)$} \\
\hline $\begin{array}{l}\text { 5. Рівень зайнятості працездатного } \\
\text { населення, \% }\end{array}$ & $\boldsymbol{k}_{7}$ & стимулятор & 64,5 & 48,0 & 0,744 \\
\hline \multicolumn{6}{|l|}{ 6. Довготривале безробіття, \% } \\
\hline більше 12 місяців & $\boldsymbol{k}_{g}$ & дестимулятор & 25,0 & 33,0 & 0,7576 \\
\hline від 7 до 12 місяців & $k_{9}$ & дестимулятор & 12,7 & 30,0 & 0,4233 \\
\hline 7. Загальний рівень безробіття, \% & $k_{10}$ & дестимулятор & 9,9 & 12,0 & 0,825 \\
\hline $\begin{array}{l}\text { 8. Статус зайнятості (оплачувана } \\
\text { робота), \%: }\end{array}$ & $k_{11}$ & стимулятор & 55,9 & 48,0 & 0,8586 \\
\hline \multicolumn{6}{|c|}{ ІІІ. Доступність / недоступність соціальних послуг ( $\left.K_{\text {дост. сои. посл. }}\right)$} \\
\hline 9. Недостатність коштів для: & & & & & \\
\hline $\begin{array}{l}\text { 9.1. Отримання медичних по- } \\
\text { слуг, \%: }\end{array}$ & $\boldsymbol{k}_{12}$ & дестимулятор & 29,7 & 38,0 & 0,7816 \\
\hline 9.2. Придбання ліків & $k_{13}$ & дестимулятор & 25,7 & 48,0 & 0,5354 \\
\hline $\begin{array}{l}\text { 9.3. Оплати послуг лікаря, аналі- } \\
\text { зів, медичних обстежень }\end{array}$ & $k_{14}$ & дестимулятор & 23,0 & 24,0 & 0,958 \\
\hline $\begin{array}{l}\text { 10. Недостатність коштів для отри- } \\
\text { мання будь-якої професії, \% }\end{array}$ & $\boldsymbol{k}_{15}$ & дестимулятор & 8,3 & 20,0 & 0,415 \\
\hline $\begin{array}{l}\text { 11. Недостатність коштів для опла- } \\
\text { ти орендних платежів, житлово-ко- } \\
\text { мунальних послуг, \% }\end{array}$ & $k_{16}$ & дестимулятор & 28,3 & 50,0 & 0,566 \\
\hline $\begin{array}{l}\text { 12. Рівень недоступності працевла- } \\
\text { штування, } \%\end{array}$ & $k_{17}$ & дестимулятор & $44,03 *$ & 47,0 & 0,9368 \\
\hline \multicolumn{6}{|c|}{ IV. Соціальна справедливість та соціальне включення $\left(K_{\text {соц.спр. }}\right)$} \\
\hline $\begin{array}{l}\text { 13. Рівень дискримінації, утиску } \\
\text { прав і інтересів, \% }\end{array}$ & $k_{18}$ & дестимулятор & 11,9 & 13,0 & 0,9154 \\
\hline $\begin{array}{l}\text { 14. Рівень довіри до місцевого на- } \\
\text { селення,\% }\end{array}$ & $k_{19}$ & стимулятор & 85,3 & 56,0 & 0,6565 \\
\hline $\begin{array}{l}\text { 15. Недостатнє забезпечення со- } \\
\text { ціальної справедливості,\% }\end{array}$ & $k_{20}$ & дестимулятор & 88,4 & 96,0 & 0,9208 \\
\hline $\begin{array}{l}\text { 16. Самооцінка рівня інтегрованос- } \\
\text { ті в територіальні громади, \% }\end{array}$ & $k_{21}$ & стимулятор & 88,9 & 38,0 & 0,4274 \\
\hline
\end{tabular}

*Визначено як добуток частки найманих працівників серед респондентів (80,2 \%) та частки тих, які відповіли, що важко знайти будь-яку роботу у Вашому населеному пункті $(54,9 \%)$ [10].

Джерело: побудовано автором. 
Субіндекс захищеності матеріального добробуту становить $71 \%$ :

$$
K_{\text {мат. добр. }}=\sqrt[6]{0,6151 \cdot 1,202 \cdot 0,615 \cdot 0,281 \cdot 1,158 \cdot 0,875}=\sqrt[6]{0,1295}=0,71 .
$$

Захищеність матеріального добробуту ВПО на $29 \%$ нижча від захищеності постійного населення. За внутрішніми складовими простежується, що такий стан пов’язаний передовсім з нижчим рівнем середньодушових доходів ВПО. Серед переселенців він майже на $39 \%$ менший у порівнянні з постійним населенням, i, як наслідок, із нижчим його співвідношенням з фактичним прожитковим мінімумом. Серед ВПО рівень бідності за критерієм депривації «Змушені заощаджувати навіть на харчуванні» на $72 \%$ вище, ніж серед постійного населення. Незважаючи на те, що серед переселенців на 10 \% більше тих, для яких заробітна плата є основним джерелом доходу, все ж рівень захищеності їх матеріального добробуту на 29 \% нижчий, ніж серед постійного населення.

Отже, визначений рівень соціальної справедливості в забезпеченні гідного рівня матеріального добробуту для ВПО з урахуванням додатково тих матеріальних втрат, які вони понесли унаслідок необхідного виїзду з місць постійного поживання (втрата майна, житла, роботи тощо), свідчать про суттєве порушення принципів соціальної справедливості за цією складовою, що однозначно пов'язано з дискримінацією за статусом зайнятості, оплатою праці тощо. Суттєві втрати ВПО пов'язані з нижчим рівнем їх захищеності на ринку праці, про що свідчить відповідний субіндекс захищеності на ринку праці (70\%):

$$
K_{\text {зах. рин. праиі }}=\sqrt[5]{0,744 \cdot 0,7576 \cdot 0,4233 \cdot 0,825 \cdot 0,8566}=\sqrt[5]{0,1686}=0,70 .
$$

Рівень економічної захищеності на ринку праці на 30 \% нижче, ніж серед постійного населення, при цьому за всіма індикаторами оцінки цього субіндексу склалися суттєво вищі значення показників (стимуляторів) для постійного населення, відповідно, менший рівень для ВПО. Так, серед переміщених осіб на 8 \% більше осіб, які не могли працевлаштуватися понад 12 місяців, та у понад 2 рази більше тих, для яких безробіття тривало від 7 до 12 місяців. На 25,6 \% серед ВПО нижчий рівень зайнятості працездатного населення, на 14,1 \% нижча частка тих, які мають статус зайнятості «оплачувана робота».

Простежуються порушення принципів соціальної справедливості і за показниками виміру рівня доступності соціальних послуг. Субіндекс доступності соціальних послуг становить $67 \%$ :

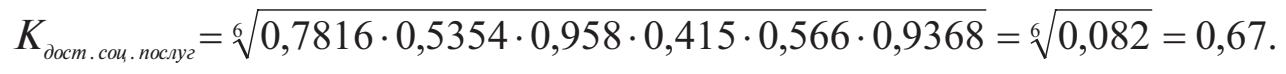

Рівень доступності ринку соціальних послуг серед ВПО на $33 \%$ менший, ніж для постійного населення, що передовсім пов'язано з недостатністю коштів для отримання професії. Цей показник на 58,5 \% менший для ВПО, ніж серед постійного населення. Порівняння показують, що у ВПО на $22 \%$ нижче можливість одержати медичні послуги, майже на 50 \% - придбати ліки. Майже на $22 \%$ серед ВПО більша частка тих, які визначають, що в них недостатньо коштів для оплати орендних платежів та житлово-комунальних послуг.

За складовою «Соціальна справедливість та соціальне включення» субіндекс визначають за чотирма індикаторами, які за змістом зіставні для ВПО, і для постійного населення. Субіндекс соціального включення становить $70 \%$ : 


$$
K_{\text {сои. сnp }}=\sqrt[4]{0,9154 \cdot 0,6565 \cdot 0,9208 \cdot 0,4274}=\sqrt[4]{0,2365}=0,7 .
$$

Забезпечення рівня соціальної справедливості за цим субіндексом серед ВПО також на 30 \% нижче, ніж для постійного населення, що обумовлено, зокрема, відмінністю самооцінки рівнів інтегрованості в життя територіальних громад, - майже на 57,3 \% він нижчий серед ВПО, ніж серед постійного населення. Цей показник корелює з оцінкою рівня довіри до місцевого населення, який також на 34,3 \% нижче серед ВПО. Необхідно звернути увагу, що майже всі переселенці (96 \%) вказали на недостатнє забезпечення соціальної справедливості для ВПО, а серед постійного населення частка таких оцінок складає близько $88 \%$.

Значення інтегрального показника зіставлення рівнів забезпечення соціальної справедливості ВПО, розраховане за формулою (1), свідчить, що рівень забезпечення соціальної справедливості за названими сферами ії прояву серед ВПО на 30,5 \% нижче, ніж серед постійного населення, при цьому практично він однаковий за всіма сферами, за якими проаналізовано прояви соціальної справедливості. Інтегральний показник забезпечення соціальної справедливості становить 69,5 \%:

$$
I_{\text {заб. сои.спр }}=\sqrt[4]{0,71 \cdot 0,7 \cdot 0,67 \cdot 0,7}=\sqrt[4]{0,233}=0,695 .
$$

У результаті виконаних розрахунків визначено, що найбільше проявлена соціальна несправедливість по відношенню до ВПО за такими складовими:

- рівень матеріального забезпечення, за яким рівень бідності серед ВПО за критерієм депривації в 3,6 разів вищий, ніж серед постійного населення. Майже кожний десятий переселенець визнав, що змушений був заощаджувати навіть на харчуванні;

- у зв'язку з недостатністю коштів переселенці обмежені в можливості отримати будь-яку професію, придбати ліки, оплатити орендні платежі та житловокомунальні послуги;

- серед ВПО значно вищий рівень безробіття, особливо довготривалого;

- простежується значний рівень соціального виключення з життя територіальних громад, лише кожна третя із ВПО вважає, що достатньо інтегрована, тоді як серед постійного населення цей показник становить $90 \%$.

Висновки. Результати виконаного дослідження свідчать про досить суттєве порушення базових принципів соціальної справедливості по відношенню до ВПО у порівнянні з постійним населенням, а також посилюються прояви несправедливості та дискримінації стосовно вимушених переселенців, які помітні переважно у таких сферах.

1. Основна сфера прояву соціальної несправедливості для ВПО пов'язана зі зменшенням рівня матеріальної захищеності протягом останніх півтора року та суттєво нижчим його рівнем в порівнянні з постійним населенням - на 38,5 \% середній рівень доходу на одну особу менший для контингетну ВПО, рівень бідності серед ВПО за критерієм депривацій більше на 13,5 в. п.

2. Втрата доходу, роботи, бізнесу, прояви дискримінації під час прийому на роботу, зайнятість на робочих місцях, які не відповідають рівню кваліфікації та професійної підготовки, зростання рівнів незайнятості серед працездатного контингенту ВПО, довготривале безробіття, яке суттєво вище, ніж серед контингенту постійного населення - на 17,3 в. п. 
3. Відчуття дискримінації у ВПО виникає, коли необгрунтовано призупиняються соціальні виплати переселенцям, а відновлення їх пов'язано із принизливими процедурами перевірок, наданням доказів правомірності відновлення виплат тощо. У зв'язку з цим серед ВПО формується відчуття соціально-психологічного травмування, соціального відторгнення, неповноцінності як громадянина України, рівноправного 3 постійним населенням.

4. Прояви соціальної несправедливості щодо ВПО визначаються переходом із категорії заможних у категорію «нових бідних» або навіть злиденних, втратою відповідного статусу зайнятості, соціального статусу в місцях теперішнього проживання, втратою виборчих прав як громадян України тощо. Всі прояви соціальної несправедливості відносно ВПО супроводжуються проявами дискримінації у сфері доступності соціальних послуг (освіта, охорона здоров’я, адміністративні послуги тощо), забезпечення житлом та на ринку праці. Частка осіб серед ВПО на 22,3 в. п. більша, ніж серед постійного населення за цим напрямом прояву дискримінації.

5. У більшості випадків серед постійного населення ВПО розглядається як обтяження, з появою якого в територіальній громаді поселення погіршуються можливості доступу до основних соціальних послуг, на них необгрунтовано переносять провину за події на Сході України. Як наслідок, погіршуються умови інтеграції переміщених осіб у територіальні громади, що в свою чергу супроводжується посиленням проявів соціальної несправедливості.

Нереалізованість принципів соціальної справедливості по відношенню до ВПО обумовлена безвідповідальністю держави у виконанні конституційних зобов'язань. Проявами цього є: невбудованість законодавства про ВПО в законодавчу систему України; відсутність компенсацій за майнові втрати; нерозв’язаність житлових проблем ВПО; невиконання чинного законодавства про ВПО; обмеження політичних та виборчих прав ВПО як громадян України; слабка підтримка розвитку підприємництва та соціальних підприємств ВПО; порушення трудових прав переміщених осіб, зокрема поширення тіньової зайнятості серед переселенців, дискримінація за статусом ВПО тощо.

Мінімізація проявів дискримінації до ВПО з подальшим досягненням соціальної справедливості буде сприяти зростанню довіри суспільства до влади, забезпечить розвиток суспільних відносин на засадах партнерства, обумовить виконання Керівних принципів з питань переміщення осіб у середині держави, які міжнародна спільнота застосовує для захисту прав ВПО та підвищення відповідальності держави у цій сфері, а також забезпечить гарантування прав і свобод громадян у процесах вимушеного переселення.

\section{ЛІТЕРАТУРА}

1. Звіти з Національної системи Моніторингу ситуації з внутрішньо переміщеними особами Раунд 8 [Електронний ресурс]. - Режим доступу: http://iom.org.ua/sites/default/files/nms_round_8_ december_2017_ukr_press.pdf (дата звернення: 04.03.2019).

2. Звіти з Національної системи Моніторингу ситуації з внутрішньо переміщеними особами Раунд 10 [Електронний ресурс]. - Режим доступу: http://iom.org.ua/sites/default/files/nms_ round_10_ukr_press.pdf (дата звернення: 04.03.2019).

3. Social-Justice in the EU-Index Report 2017.Social Inclusion Monitor Europe [Електронний ресурс]. - Режим доступу: www.bertelsmann-siftung.de/fileadmin/files/BSt/Publikationen/ GeraulPublskationen/Studie_NW_Social_Justice_Index_2016.pdf (дата звернення: 20.02.2019).

4. Жовновата В.О. Особливості застосування індексу соціальної справедливості в українських реаліях // Вісник ОНУ ім. І.І. Мечникова. Соціологія і політичні науки. - 2016. - Т. 21, Вип. 3 (26). - C. $20-31$. 
5. Мішук Г.Ю., Смолюк Н.Н. Вимірювання соціальної справедливості у контексті оцінки ефективності відносин розподілу у суспільстві // Демографія та соціальна економіка. - 2018. № 1 (32). - C. 58-72. - https://doi.org/10.15407/dse2018.02.058

6. Новиков В., Семенов В. Социальная справедливость: сущность, оценка, реализация. Теоретикоэкономическое исследование. 2014 [Електронний ресурс]. - Режим доступу: https://idss.org. ua/monografii/novikov_semenov.pdf (дата звернення: 05.02.2019).

7. Звіти з Національної системи Моніторингу ситуації з внутрішньо переміщеними особами Раунд 7 [Електронний ресурс]. - Режим доступу: http://iom.org.ua/sites/default/files/nms_round_7_ september_2017_ukr_0.pdf (дата звернення: 04.03.2019).

8. Звіти з Національної системи Моніторингу ситуації з внутрішньо переміщеними особами Раунд 9 [Електронний ресурс]. - Режим доступу: http://iom.org.ua/sites/default/files/nms_ round_9_ukr_press.pdf (дата звернення: 04.03.2019).

9. Національна підсистема моніторингу ситуації з внутрішньо переміщеними особами. Кумулятивний звіт за березень 2016 - червень 2017 рр. [Електронний ресурс]. - Режим доступу: http://iom.org.ua/sites/default/files/nms_cumulative_report_rounds_1_to_6_ukr.pdf(дата звернення: 11.02.2019).

10. Інтеграція ВПО у територіальні громади: діагностика стану та механізми забезпечення / О.Ф. Новікова, В.П. Антонюк, Ю.С. Залознова та ін.; НАН України, Ін-т економіки промисловості. - Київ, 2018. - 244 с.

11. Українське суспільство: Моніторинг соціальних змін / Інститут соціології НАН України. - Київ, 2016. - Вип. 3/17. - С. 503-504.

12. Внутрішньо переміщені особи: від подолання перешкод до стратегії успіху / О.Ф. Новікова, О.І. Амоша, В.П. Антонюк та ін.; НАН України, Ін-т економіки пром-сті. - Київ, 2016. $448 \mathrm{c}$.

\section{REFERENCES}

1. Zvity z Natsional'noyi systemy Monitorynhu sytuatsiyi z vnutrishn'o peremishchenymy osobamy. Raund 8 [Reports from the National Monitoring System for Internally Displaced Persons. Round 8]. (2017). Retrieved from http://iom.org.ua/sites/default/files/nms_round_8_december_2017_ukr_press.pdf [in Ukrainian]

2. Zvity $z$ Natsional'noyi systemy Monitorynhu sytuatsiyi $z$ vnutrishn'o peremishchenymy osobamy. Raund 10 [Reports from the National Monitoring System for Internally Displaced Persons. Round 10]. (2018). Retrieved from http://iom.org.ua/sites/default/files/nms_round_10_ukr_press.pdf [in Ukrainian].

3. Social-Justice in the EU-Index Report 2017 (2017). Social Inclusion Monitor Europe. Retrieved from www.bertelsmann-siftung.de/fileadmin/files/BSt/ Publikationen/GeraulPublskationen/Studie_NW_Social_Justice_Index_2016.pdf

4. Zhovnovata, V.O. (2016). Osoblyvosti zastosuvannia indeksu sotsialnoi spravedlyvosti v ukrainskykh realiiakh [Features of the application of the index of social justice in Ukrainian realities]. Visnyk ONU im. I.I. Mechnykova. Sotsiolohiia i politychni nauky - Visnyk ONU named after I. I. Mechnikov. Sociology and political science, Vol. 21, 3(26), 20-31 [in Ukrainian].

5. Micshuk, G.Yu., \& Smolianiuk, N.N. (2018). Vymiryuvannya sotsial'noyi spravedlyvosti u konteksti otsinky efektyvnosti vidnosyn rozpodilu u suspil'stvi [Measuring social justice in the context of assessing the effectiveness of distributional relations in society]. Demohrafiia ta sotsialna ekonomika [Demography and Social Economy], 1(32), 58-72 [in Ukrainian] - https://doi.org/10.15407/dse2018.02.058.

6. Novikov, V., \& Semenov, V. (2014). Social justice: the essence, evaluation, implementation. Theoretical and Economic Research [Sotsial'naya spravedlivost': sushchnost', otsenka, realizatsiya. Teoretiko-ekonomicheskoye issledovaniye]. Retrieved from https://idss.org.ua/monografii/novikov_semenov.pdf [in Russian].

7. Zvity z Natsional'noyi systemy Monitorynhu sytuatsiyi z vnutrishn'o peremishchenymy osobamy. Raund 7 [Reports from the National Monitoring System for Internally Displaced Persons. Round 7]. (2017). Retrieved from http://iom.org.ua/sites/default/files/nms_round_7_september_2017_ukr_0.pdf [in Ukrainian] 
8. Zvity z Natsional'noyi systemy Monitorynhu sytuatsiyi z vnutrishn'o peremishchenymy osobamy. Raund 9 [Reports from the National Monitoring System for Internally Displaced Persons. Round 9]. (2018). Retrieved from http://iom.org.ua/sites/default/files/nms_round_9_ukr_press.pdf [in Ukrainian]

9. Natsionalna pidsystema monitorynhu sytuatsii $z$ vnutrishno peremishchenymy osobamy. Kumulyatyvnyi zvit za berezen 2016 - cherven 2017. [National monitoring subsystem for internally displaced persons. Cumulative report for March 2016 - June 2017] (2017). Retrieved from http://iom.org.ua/sites/default/files/nms_cumulative_report_rounds_1_to_6_ukr.pdf [in Ukrainian].

10. Novikova, O.F., Antonyuk, V.P. \& Zaloznova, Yu.S et al. (2018). Intehratsiia vutrishno peremishchenykh osob u terytorialni hromady: diahnostyka stanu ta mekhanizmy zabezpechennia [Integration of internally displaced persons into territorial communities: diagnostics of the state and mechanisms of provision]. Institute of Industrial Economics of NAS of Ukraine. Kyiv [in Ukrainian].

11. Ukrainske suspilstvo: Monitorynh sotsialnykh zmin [Ukrainian society: monitoring of social change] (Issue 3/17). (2016). Institute of Sociology of NAS of Ukraine. Kyiv [in Ukrainian].

12. Novikova, O.F., Amosha, O.I., \& Antonyuk, V.P. et al. (2016). Vnutrishno peremishcheni osoby: vid podolannya pereshkod do stratehii uspikhu [Internally displaced persons: from overcoming obstacles to the strategy of success]. Institute of Industrial Economics of NAS of Ukraine. Kyiv [in Ukrainian].

Стаття надійшла до редакції 15.04.2019. 


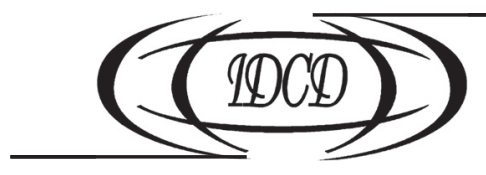

https://doi.org/10.15407/dse2019.02.121

УДК 314.174(477); 330.3+336 (477)

JEL CLASSIFICATION: I30

\title{
В.П. ЗВОНАР
}

д-р екон. наук, старш. наук. співроб., провідний наук. співроб.

Інститут демографії та соціальних досліджень імені М.В. Птухи НАН України

01032, Україна, м. Київ, бул. Т. Шевченка, 60

E-mail: viktorzvonar@yahoo.com

ORCID 0000-0003-1300-4791

\section{ФІНАНСУВАННЯ СОЦІАЛНОГО РОЗВИТКУ СЕЛА ЗА УЧАСТЮ ІНСТИТУТІВ ГРОМАДЯНСЬКОГО СУСПІЛЬСТВА}

\begin{abstract}
Метою статті є визначення можливостей $і$ засобів фінансування соціального розвитку сільських громад в Україні з використанням соціоекономічного потенціалу інститутів громадянського суспільства. Актуальність пошуку та вивчення таких можливостей $і$ засобів зумовлена неподоланими досі кризовими явищами у соціальній сфері на рівні сільських поселень та районів і фактичним ігноруванням науковиями та практиками вагомого резерву та імпульсу розвитку цієї сфери, яким може стати дiяльність і фінансово-організаційні ресурси численних громадських об'єднань. Виявлено, що з методологічного погляду дослідження та організація участі громадянського суспільства у вирішення комплексу соціальних проблем села не повинні обмежуватися спектром власне сільських громадських утворень (місцевих організацій села, селища, району, а мають спиратися на потенціал національного сектору некомерційних неурядових формувань, як і враховувати можливості допомоги з боку міжнародних інститутів, що демонструють зацікавленість сільською соціальною проблематикою. Запропоновано та обгрунтовано способи фінансової підтримки соціальної сфери сільської території, які передбачають громадське спрямування як соціальних інвестицій бізнесу, так і частини коштів місцевих бюджетів, зокрема через новітній інструмент соціальних облігацій та удосконалення порядку адміністрування податку на доходи фізичних осіб і запровадження так званої відсоткової філантропії на місцевому рівні. Окреслено перспективи та доведено важливість активізації власне громадських джерел фінансування соціального розвитку села, наприклад, краудфандингу. Розраховано, що потенційна вигода від використання інструментарію громадянського суспільства для потреб розвитку сільських громад може сягати кількасот мільйонів гривень щороку і сприяти вирішенню питань матеріально-технічного забезпечення певних об'єктів соціальної інфраструктури.
\end{abstract}

Ключові слова: громадські інститути, фінансові інструменти, сільська громада, ресурси.

\section{В.П. Звонарь}

д-р. экон. наук, старш. науч. сотр., вед. науч. сотр.

Институт демографии и социальных исследований имени М.В. Птухи НАН Украины

01032, Украина, г. Киев, бул. Т. Шевченко, 60

E-mail: viktorzvonar@yahoo.com

ORCID 0000-0003-1300-4791

(C) ЗВОНАР В.П., 2019

ISSN 2072-9480. Демографія та соціальна економіка, 2019, № 2(36): 121-136 


\section{ФИНАНСИРОВАНИЕ СОЦИАЛЬНОГО РАЗВИТИЯ СЕЛА С УЧАСТИЕМ ИНСТИТУТОВ ГРАЖДАНСКОГО ОБЩЕСТВА}

Цель статьи - определение возможностей и средств финансирования социального развития сельских общин в Украине с использованием социоэкономического потенциала институтов гражданского общества. Актуальность поиска и изучения таких возможностей и средств обусловлена кризисными явлениями в социальной сфере на уровне сельских поселений и районов и фактическим игнорированием учеными и практиками весомого резерва и импульса развитию этой сферы, которым может стать деятельность и финансово-организационные ресурсы многочисленных общественных объединений. Выявлено, что с методологической точки зрения исследования и организация участия гражданского общества в решении комплекса социальных проблем сельской местности не должны ограничиваться спектром собственно сельских общественных образований (местных организаций села / поселка, района). Необходимо также учитывать потенциал национального сектора некоммерческих неправительственных формирований, как и возможности помощи со стороны международных институтов, демонстрирующих заинтересованность сельской социальной проблематикой. Предложены и обоснованы способы финансовой поддержки социальной сферы сельской местности, предусматривающие использование как социальных инвестиций бизнеса, так и части средств местных бюджетов, в том числе, посредством инструмента социальных облигаций и усовершенствования порядка администрирования налога на доходы физических лии и введения так называемой процентной филантропии на местном уровне. Определены перспективы и доказана важность активизации собственно общественных источников финансирования социального развития села, например, краудфандинга. Рассчитано, что потенциальная выгода от использования инструментария гражданского общества для нужд развития сельских общин может достигать нескольких миллионов гривен в год и способствовать решению отдельных вопросов материально-технического обеспечения объектов социальной инфраструктуры.

Ключевые слова: общественные институты, финансовые инструменты, сельская община, ресурсы.

\section{V.P. Zvonar}

Dr. Sc. (Economy), senior researcher, leading staff scientist

Ptoukha Institute for Demography and Social Studies

of the National Academy of Sciences of Ukraine

01032, Ukraine, Kyiv, Taras Shevchenko Blvd., 60

E-mail: viktorzvonar@yahoo.com

ORCID 0000-0003-1300-4791

\section{FINANCING OF RURAL COMMUNITIES SOCIAL DEVELOPMENT: THE STAKE OF CIVIL SOCIETY INSTITUTIONS}

The paper aims to outline the possibilities and the tools of financing of social development of rural communities in Ukraine the socioeconomic potential of civil society institutions having being taken into account. The issue is considered pressing due to the lack of contributing and focused research into social factors of socioeconomic reforms, both expected and implemented in the country at the level of rural settlements and districts. Another reason to bring the issue into the foreground is the current ineffectiveness of the conventional means of socioeconomic impact employed to balance humanitarian and economic constituents of rural development. Finally, the issue reveals the unheeded importance of continuous cooperation of various agents of reform. In the paper, the system approach, the method of logical models constructing, the comparative approach, and the case method are used as the research techniques. The research argues that methodologically and technically the participation of civil society in solving a set of social problems in rural areas should not be limited to the spectrum of rural civil institutions (community-based organizations). The potential of the national sector of non-profit non-governmental organizations, as well as the possibilities of assistance of international institutions are also relevant. The paper offers the methods of financing the social sphere of rural areas through civil society efforts. The author gives the reasons for the wider use of crowdfunding, social bonds and some other innovative financial tools in Ukraine to finance the social development of rural areas. The paper claims that the specific economic and organizational measures for enhancing of financial impact of civil society are required to facilitate the social development of rural areas in Ukraine. The set of the relevant measures are to be developed and exploited by the civil society organizations in conjunction with the state authorities responsible for the implementation of the social policy's agenda in Ukraine. The priorities and the activity tasks for the civil society and for the public agencies are identified in the paper as well.

Keywords: civil institutions, financial instruments, rural community, resources. 
Постановка проблеми та актуальність. Проблема низького фінансового самозабезпечення сільських громад в Україні десятиліттями не втрачає своєї гостроти. Ресурсна обмеженість особливо ускладнює реалізацію соціальних пріоритетів розвитку села. При цьому у науковій літературі і в практиці соціально-економічних реформ досі недооціненими залишаються можливості та перспективи використання фінансових інструментів, безпосередньо зумовлених чи пов'язаних із діяльністю громадянського суспільства - сукупності інституціоналізованих чи неформальних об’єднань громадян.

Практичний досвід та емпіричні спостереження останніх років доводять, що громадянське суспільство як суспільний інститут виявляє високу готовність і здатність упроваджувати конструктивні зміни в Україні. Воно стоїть сьогодні в авангарді розроблення дорожньої карти ключових реформ, першим мобілізувало національні ресурси для забезпечення вітчизняного війська в умовах зовнішньої агресії, опікується вирішенням найгостріших внутрішніх соціальних проблем. Громадські інститути, реагуючи на виклики розвитку сільських територій, створюють місцеві осередки соціальної активності та самоорганізації, займаються освітою дорослих і дітей тощо. На часі питання про системне використання потенціалу громадянського суспільства, зокрема у фінансово-ресурсному аспекті, для широкого спектру соціальних потреб українського села.

Аналіз останніх досліджень. Вплив фінансових чинників на розвиток соціальної сфери країни та регіонів досліджують М. Карлін (M. Karlin), В. Кравців (V. Kravtsiv), Е. Лібанова (E. Libanova) та ін. Пошук резервів виходу сільських поселень із соціально-економічної кризи перебуває у сфері наукових інтересів Т. Заяць (T. Zaiats) [1], I. Прокопи (I. Prokopa), О. Рогожина (O. Rogozhyn), О. Дяконенко (O. Dyakonenko) [2] та ін. Велику увагу соціально-економічному потенціалові й особливостям функціонування громадянського суспільства в Україні приділяють Д. Ляпін (D. Lyapin), Л. Паливода (L. Palyvoda), Ю. Опалько (Yu. Opalko) та ін. Проблематику громадських за природою фінансових новацій в економіці України (наприклад, краудфандингу і філантропії) вивчають, зокрема, А. Гулевська-Черниш (A. Gulevska-Chernysh), C. Куц (S. Kuts), I. Ткачук (I. Tkachuk). Водночас питання використання цих та інших новацій для реалізації соціальних потреб сільської місцевості залишаються слабко вивченими.

Новизна роботи. Досліджено потенціал та обгрунтовано способи фінансового забезпечення сільських громад в Україні за організаційної участі громадських утворень задля необхідної активізації соціального розвитку.

Мета статті - виявлення перспектив та визначення способів фінансування соціального розвитку сільських територій в Україні на засадах залучення інститутів громадянського суспільства.

Методи дослідження. У роботі використано системний підхід, метод побудови логічних моделей, порівняльний підхід, метод аналізу конкретних прикладів (кейсметод). Дослідження фінансових та інших можливостей громадянського суспільства методологічно ускладнюються тим, що останнє є вкрай неоднорідним і загалом важко піддається безпосередньому аналізу [3]. А наявні методичні ресурси залишаються недосконалими і недостатніми для однозначних висновків. Крім того, без заглиблення в історію та нюанси функціонування кожної організації важко оцінити, наскільки сільська проблематика є актуальною для їі активістів. Логіка підказує, що цією проблематикою переймаються найперше місцеві сільські / селищні організації. Але статистичних даних окремо за цією категорією організацій у відкритому доступі немає. Як видається, таких організацій загалом небагато порівняно з кількістю та 
різноманіттям громадських структур у містах, де рівень ділової активності традиційно значно вищий, ніж у сільських громадах. Водночас із практики відомо, що інтерес до вирішення сільських проблем демонструють як місцеві організації / сільські активісти, так і міські, обласні, всеукраїнські організації, а також представництва закордонних неурядових некомерційних структур [4]. Тому, досліджуючи особливості громадського фінансування сільського розвитку, автор не обмежується спектром лише сільських громадських організацій.

Виклад основного матеріалу дослідження. Оцінюючи загальну кількість громадських формувань у країні, які могли б долучитися до фінансування сільського розвитку, перш за все треба звернутися до даних Єдиного державного реєстру підприємств та організацій України (ЄДРПОУ). Він чи не найповніше відображає спектр організаційно-правових форм, яких можуть набувати організації громадянського суспільства. Враховуючи дані ЄДРПОУ, можна кількісно оцінити громадянське суспільство з огляду на такі структурні елементи: громадська організація, громадська спілка, релігійна організація, профспілка, творча спілка, благодійна організація, підприємство громадського об'єднання, установа / заклад такого об'єднання, об'єднання співвласників багатоквартирних будинків (ОСББ), обслуговуючий кооператив. Указаний перелік об’єднує найменш суперечливі за суттю інститути громадянського суспільства. Хоча дискусія про структуру громадського сектору у фахових джерелах нині триває.

При цьому однозначно стверджувати про сільську локалізацію можна лише щодо сільськогосподарських обслуговуючих кооперативів, які, на відміну від виробничих і споживчих кооперативів, вважають неприбутковими організаціями. Вони надають своїм членам широкий спектр послуг, зокрема заготівельні, транспортні, ремонтні, будівельні, ветеринарні тощо.

Отже, динаміка кількості основних видів організацій громадянського суспільства впродовж 2010-2017 рр. демонструє щорічне зростання як загалом кількості організаційних одиниць, так і одиниць майже кожної їх окремої організаційно-правової форми, крім обслуговуючих коопереативів та підприємств і установ громадських об’єднань (табл. 1).

Наведені дані уможливлюють розрахунок показника кількості організацій на 100 тис. наявного сільського населення. Динаміка цього показника може опосередковано вказувати на потенціальну змогу громадянського суспільства охопити та відобразити у своїй діяльності різні аспекти життя сільських мешканців. Як бачимо, зазначений індикатор теж стабільно зростав.

Зауважимо, що тенденція кількісного зростання характерна і для вітчизняних організацій із однозначною сільською локалізацією діяльності - сільськогосподарських обслуговуючих кооперативів. На рис. 1 відображено динаміку зміни їх кількості, яка дещо уповільнилася на зламі 2013-2014 pр., але загалом відзначається стійким нарощуванням.

3 огляду на такі кількісні оцінки можна зробити висновок про посилення позицій громадянського суспільства в Україні в останні роки. На це вказують також деякі макроекономічні оцінки (позиціювання громадського сектору у складових ВВП, створювана ним валова додана вартість тощо), аналіз конкретних успішних прикладів його соціоекономічного впливу у науковій літературі, як, наприклад у [5]. Громадянське суспільство та задіяні ним інструменти (зокрема, фінансові) здатні конструктивно впливати на соціально-економічний розвиток як великих, так i малих громад. 
Таблиця 1. Різноманіття організацій громадянського суспільства як інституційна основа інноваційного фінансування сільського розвитку в Україні

\begin{tabular}{|c|c|c|c|c|c|c|c|c|}
\hline $\begin{array}{c}\text { Організаційно-правові } \\
\text { форми }\end{array}$ & 2010 & 2011 & 2012 & 2013 & 2014 & 2015 & 2016 & 2017 \\
\hline $\begin{array}{l}\text { Підприємства громад- } \\
\text { ських об’єднань }\end{array}$ & 3425 & 3366 & 3370 & 3357 & 3247 & 3288 & 3313 & 3276 \\
\hline $\begin{array}{l}\text { Установи/заклади об'єд- } \\
\text { нань }\end{array}$ & 1347 & 1458 & 1487 & 1518 & 1592 & 1602 & 1581 & 1536 \\
\hline Громадські організації & 51567 & 55339 & 58010 & 60516 & 64175 & 70321 & 75988 & 80461 \\
\hline Громадські спілки & 143 & 166 & 188 & 311 & 511 & 753 & 990 & 1254 \\
\hline Релігійні організації & 19481 & 20298 & 20900 & 21637 & 22219 & 23261 & 24072 & 25223 \\
\hline $\begin{array}{l}\text { Профспілки, їх об’єд- } \\
\text { нання }\end{array}$ & 21940 & 23290 & 24348 & 25176 & 25824 & 26321 & 26899 & 27601 \\
\hline Творчі спілки & 223 & 232 & 240 & 258 & 267 & 279 & 292 & 311 \\
\hline Благодійні організації & 9604 & 10180 & 10721 & 11615 & 13399 & 15384 & 16837 & 17726 \\
\hline ОСББ & 10833 & 12660 & 13738 & 14865 & 15689 & 17109 & 26080 & 27999 \\
\hline $\begin{array}{l}\text { Обслуговуючі коопера- } \\
\text { тиви }\end{array}$ & 17499 & 16779 & 16362 & 16368 & 16660 & 17439 & 18169 & 18654 \\
\hline Разом & 136062 & 143768 & 149364 & 155621 & 163583 & 175757 & 194221 & 204041 \\
\hline $\begin{array}{l}\text { Організацій на } 100 \text { тис. } \\
\text { наявного сільського на- } \\
\text { селення }\end{array}$ & 1002 & 1065 & 1113 & 1167 & 1234 & 1334 & 1482 & 1568 \\
\hline
\end{tabular}

Джерело: складено за даними Держслужби статистики України без урахування АР Крим та м. Севастополь. [Електронний ресурс]. - Режим доступу: http://www.ukrstat.gov.ua

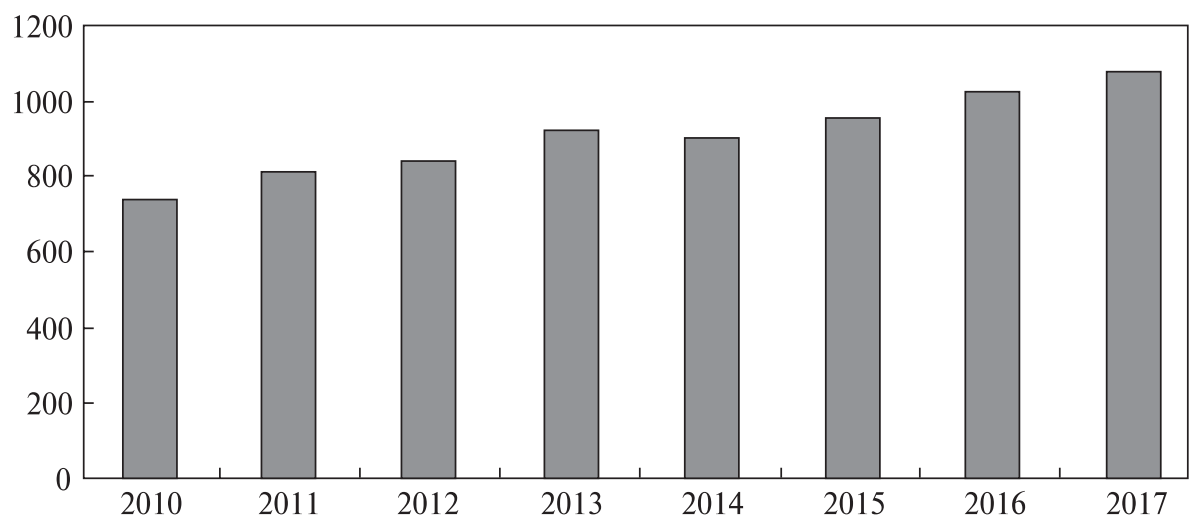

Рис. 1. Кількість сільськогосподарських обслуговуючих кооперативів в Україні, організаційні одиниці

Джерело: складено за даними Держслужби статистики України без урахування АР Крим та м. Севастополь. [Електронний ресурс]. - Режим доступу: http://www.ukrstat.gov.ua

На нашу думку, фінансування соціально-економічного розвитку сільських територій на засадах залучення інститутів громадянського суспільства передбачає, по-перше, громадське спрямування фінансових ресурсів (благодійних внесків бізнесу ISSN 2072-9480. Демографія та соціальна економіка, 2019, № 2 (36) 


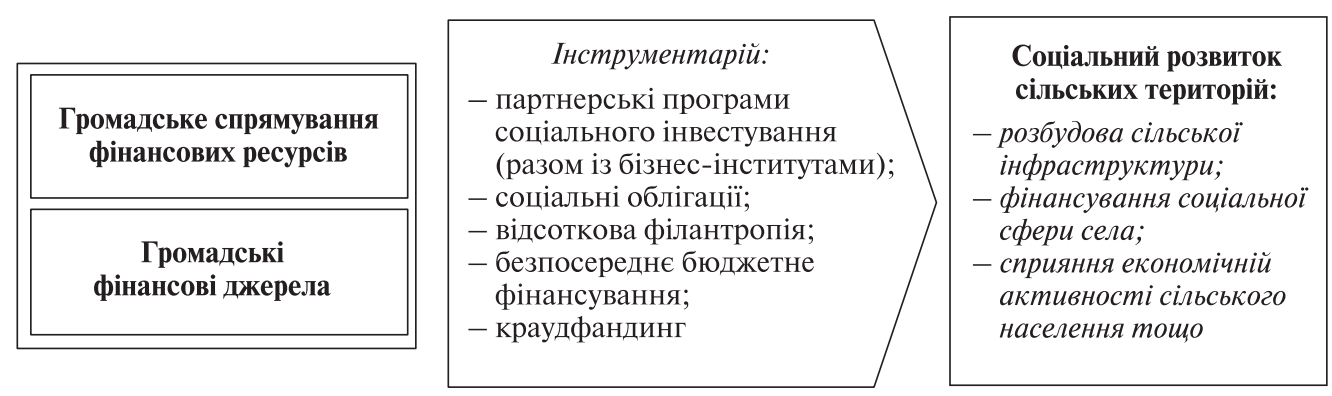

Рис. 2. Форми фінансування сільського розвитку на засадах громадської участі

Джерело: авторська розробка.

чи населення, бюджетних асигнувань з боку місцевих органів влади, коштів із інших не заборонених законодавством джерел) на реалізацію значущих для сільського розвитку громадських проектів і програм, які інститути громадянського суспільства можуть розробляти самостійно або у співпраці з бізнесом, державними закладами та органами місцевого самоврядування (рис. 2).

По-друге, треба розглянути питання про активізацію власне громадських джерел фінансування. На жаль, їхній потенціал в Україні фактично ігнорують. Зрозуміло, що ці джерела не можуть бути єдиними чи пріоритетними та мають залучатися разом із коштами бізнесу чи ресурсами місцевих бюджетів. Водночас активне використання громадських - некомерційних і не бюджетних - фінансів є бажаним, бо в такий спосіб урізноманітнюються ресурсні потенції сільської територіальної громади для фінансового забезпечення іiі соціальної сфери.

Окреслюючи спектр фінансових ресурсів, які потенційно можуть отримати громадське спрямування, варто оцінити способи залучення насамперед коштів бізнесу. Участь комерційних підприємств у розбудові сільської інфраструктури та соціальної сфери може опосередковуватися фінансовими програмами корпоративної соціальної відповідальності (КСВ), а саме - програмами соціального інвестування, тобто вкладення бізнесом вільних ресурсів у соціально важливі (у т. ч. громадські) ініціативи. Необхідно акцентувати на тому, що соціальні інвестиції - це не беззвітна / безконтрольна благодійність, а доцільні, належним чином розраховані та контрольовані витрати з метою отримання конкретного соціального ефекту. Вони можуть набувати форми грантів, цільової допомоги, пільгової позики тощо.

У контексті перспективи громадського спрямування соціальних інвестицій бізнесу особливої уваги заслуговує інструмент соціальних облігацій (облігацій соціального впливу) - новітній засіб мобілізації приватних фінансів для досягнення визначених соціальних цілей [6]. Із закордонних джерел відомо, що емісію цих облігацій, як правило, ініціює організація, основною діяльністю якої є вирішення соціальних проблем (наприклад, підприємство громадського об'єднання). Таку емісію зазвичай обслуговують незалежні компетентні інститути - інвестиційні компанії та банки. Інші зацікавлені бізнес-інститути вільно купують емітовані соціальні облігації, демонструючи свою КСВ.

Зі свого боку органи місцевого самоврядування надають гарантії під ці облігації за рахунок бюджетних коштів. Тобто у разі успіху соціальної акції, для якої залучалися кошти, місцева влада компенсує приватному інвесторові понесені витрати з невели- 
ким фіксованим відсотковим доходом. Якщо акція виявилася безрезультатною і не мала належного соціального ефекту, кошти за соціальними облігаціями інвесторам не виплачуються. Аналіз результативності соціальної акції здійснюють незалежні оцінювачі [7].

Мотивація з боку місцевої влади стосовно гарантування соціальних облігацій полягає у тому, що виплати приватному інвестору є відтермінованим зобов’язанням. А залучені від нього кошти дають змогу невідкладно ініціювати необхідні заходи соціальної політики. Якщо виконавцем цих заходів зголошується бути чи від початку є визначена громадська (недержавна) структура, то очікується, що виплати інвестору за соціальними облігаціями будуть меншими, ніж витрати безпосередньої роботи бюджетних (публічних) виконавців.

Соціальні облігації запроваджуються для фінансування соціального розвитку в багатьох країнах, часто - в порядку експерименту. Наприклад, у Великій Британії в 2010 р. у такий спосіб було ініційовано фінансування програми соціальної і трудової реабілітації осіб, звільнених із місць позбавлення волі. В Україні на разі мова йде лише про перспективу запровадження цього типу облігацій. Тим часом їх умовним прототипом іноді вважають облігації внутрішньої державної позики «Військові облігації, випущені урядом у 2014 р. з метою залучення додаткових коштів для забезпечення потреб національного війська [8]. На цій основі вчені сьогодні активно висловлюються на користь широкого використання соціальних облігацій для фінансового сприяння діяльності соціально орієнтованих громадських структур [9]. Вважаємо, що належне місце серед них мають посісти ті, які опікуються соціальним розвитком сільської території, і ті, цільовою групою яких є сільське населення.

Припускаємо, що гарантування за соціальними облігаціями, випущеними для забезпечення розвитку сільських територій, може стати новим перспективним проявом КСВ вітчизняного агропромислового бізнесу. Ймовірно, комерційні структури (агрохолдинги, підприємства харчової і легкої промисловості тощо), які бажають продемонструвати суспільству соціальну складову своєї діяльності, могли б не тільки купувати, а й гарантувати соціальні облігації громадських структур у разі успішного досягнення соціальних цілей. На нашу думку, зазначена фінансова новація може виявитися актуальною для підтримки громадських ініціатив низки некомерційних установ та організацій у сільських громадах - зокрема, сільських шкіл, які нерідко стають майданчиками для згуртування сільської громади.

Звертаємо увагу на ще один новий спосіб участі публічного сектору у фінансуванні громадських інститутів та їх суспільно значущих заходів, а саме - на відсоткову філантропію (трансфер податку). Його суть полягає в тому, що пересічний платник податку на доходи фізичних осіб отримує право переадресувати певний установлений законом відсоток суми цього податку до організації, яка декларує соціальні цілі або реалізує суспільних інтерес [10]. Історичним прототипом відсоткової філантропії хрестоматійно вважаються спроби вирішити проблему фінансування церкви після секуляризації європейських суспільств, що тривала до середини XX ст. Для цього деякі країни (наприклад, Німеччина й Австрія) запровадили спеціальний церковний податок, який сплачується вірянами й адмініструється державою на користь відповідної конфесії. Інші країни (Італія й Іспанія) передбачили можливість для платників звичних прямих податків (зокрема, прибуткового) сплачувати частину суми податку не до бюджету, а на рахунок католицької громади. Згодом до переліку бенефіціарів було включено громади інших релігійних конфесій, державні установи й організації громадянського суспільства. 
До італійського досвіду звернулися країни Центральної та Східної Європи після розпаду соціалістичного табору та відродження релігійних свобод і демократичних традицій. Першою у цьому питанні стала Угорщина в середині 90-х рр. XX ст. Дискусія, що розпочалася з окреслення проблеми фінансування церкви у цій країні, завершилася визнанням не тільки необхідності широкого спектру отримувачів коштів, а й пріоритетності саме світських бенефіціарів в особі громадських організацій, що надають населенню соціальні послуги. Позитивні результати угорського уряду зумовили поширення відсоткової філантропії на поч. 2000-х рр. для світських цілей у Польщі, Словаччині, Румунії, Литві тощо. Цей спосіб мобілізації коштів сьогодні активно обговорюється законотворцями і планується до впровадження у Молдові, Чехії, Македонії, Швейцарії, Японії.

В Україні подібна дискусія триває з 2009 р., коли громадські активісти презентували у Львові підготовлений законопроект, призначення якого - регулювання механізму відсоткової філантропії (офіційно - трансферу податку). У 2010 р. цей документ було зареєстровано у Верховній Раді України, але невдовзі знято з розгляду з причини ухвалення Податкового Кодексу України. У 2012 р. зацікавлені громадські організації відновили роботу у цьому напрямі: було напрацьовано новий рамковий законопроект. За активної позиції громадськості у 2015 р. ініційовано його розгляд у парламенті.

У законопроекті, зокрема, передбачено право платника податку з доходів фізичних осіб доручити відповідним органам перерахувати на користь однієї з неприбуткових організацій 2 \% від суми податку, сплаченого за звітний рік. Отримати кошти може організація, яка функціонує на території України в статусі неприбуткової організації не менше року. При цьому неприбутковими організаціями вважаються установи, включені до відповідного державного реєстру згідно з ознакою неприбутковості (громадські об’єднання, благодійні та релігійні організації, бюджетні установи тощо). Водночас законопроект уточнює, що бенефіціарами не можуть бути органи державної влади, органи місцевого самоврядування, житлово-будівельні кооперативи, об'єднання співвласників багатоквартирних будинків, політичні партії, фонди соціального страхування, кредитні та професійні спілки, об’єднання юридичних осіб. Процедурно трансфер податку виглядає як перерахування казначейством коштів з бюджетного рахунку на банківський рахунок відповідної неприбуткової організації - на основі розрахунків податкового органу, здійснених на підставі даних, вказаних у податкових деклараціях громадян.

Підтримуючи цю ініціативу в цілому, вважаємо, що для цілей фінансового забезпечення сільського розвитку в Україні об’єкт і процедуру відсоткової філантропії треба дещо трансформувати. Недоцільно обмежуватися аспектами утримання конкретної неприбуткової організації (нехай навіть найбільш прогресивної і дійсно вартої підтримки). Натомість трансфер податку треба орієнтувати в першу чергу на досягнення визначеного соціально-економічного результату конкретної громади, робота над ним може потребувати зусиль не однієї організації, а залежати від злагодженого співробітництва між кількома зацікавленими установами. 3 цих міркувань пріоритетним об’єктом відсоткової філантропії має стати певна програма дій або соціальний проект із визначеними цілями, строками, виконавцями, територією реалізації.

Програмне (проектне) спрямування коштів від відсоткової філантропії на потреби сільського розвитку, очевидно, вимагатиме і певних змін технічної процедури ії здійснення. Звісно, годі розраховувати, що пересічний платник податків вникатиме у технічні нюанси проектної діяльності неприбуткової організації, вирішуючи ії під- 
тримати. Очікувано він великою мірою керуватиметься суб’єктивними симпатіями. У цьому зв’язку пропонуємо два сценарії організації трансферу податку. Перший сценарій передбачає, що організації, які бачать себе потенційними реципієнтами трансферу податку, мають публічно засвідчити свою прихильність і готовність до проектного способу використання мобілізованих коштів (презентувати населенню проект, під який вони очікують надходження коштів). Відтак громадяни, симпатизуючи комусь, все ж оцінюватимуть не організації як такі, а проектні громадські ініціативи. Про результати освоєння отриманих коштів організації зобов'язуються публічно прозвітувати. Наявність і змістовність звіту стане умовою допуску організацій до розподілу трансферу податку у наступному фіскальному періоді.

Другий сценарій передбачає спрямування відповідними податковими органами і казначейством мобілізованих сум податку на рахунки обмеженого переліку обраних організацій, які у свою чергу зобов'язані здійснити селекцію та профінансувати громадські проекти і програми. За цього сценарію платник податків у податковій декларації указуватиме не організацію, яку хотів би підтримати, а бажаний проблемний (проектний) напрям роботи, що видається йому вартим фінансового зосередження.

Для розуміння обсягів потенційної вигоди від запровадження трансферу податку у фаховій літературі наводять розрахунки за загальною формулою [11]:

$$
M=\operatorname{Tax} \times r,
$$

де $M$ - сума мобілізованих коштів, Тax - сума податку на доходи фізичних осіб, $r$ - ставка, за якою здійснюється трансфер (у згаданому законопроекті - 2 \%).

Якщо спиратися на дані 2017 р., коли надходження від податку на доходи фізичних осіб до зведеного бюджету України становили близько 186 млрд грн (за звітами Міністерства фінансів України), то мобілізована сума могла б виявитися доволі значною - 3,7 млрд грн, що суттєво сприяло би вирішенню соціальних проблем сільських громад (за умови використання всіма вітчизняними платниками податку права на відсоткову філантропію і спрямування їх внеску на розвиток сільських територій). Очевидно, що такий масштаб запровадження відсоткової філантропії є малоймовірним. Доводиться брати до уваги, передусім тих платників, для яких проб-леми сільського розвитку є найбільш значущими. Логічно припустити, що серед них превалюють особи, які зареєстровані і працевлаштовані у сільській місцевості: сплачені ними податки скеровуються до відповідних (у т. ч. сільських) бюджетів місцевого самоврядування. Після започаткування децентралізаційної реформи надходження за податком на доходи фізичних осіб актуалізуються тільки для окремих бюджетів місцевого самоврядування, зокрема для бюджетів об'єднаних територіальних громад (ОТГ). Відповідно до даних Міністерства фінансів України, у 2017 р. ОТГ акумулювали 5,2 млрд грн як надходження від податку на доходи фізичних осіб. Крім того, основна маса адміністративних районів традиційно зберігає сільську (аграрну) специфіку в Україні. Тому в контексті забезпечення сільського розвитку доречно розраховувати і на бюджети районного рівня. У 2017 р. вони акумулювали податки на доходи фізичних осіб у сумі 23,9 млрд грн. Отже, максимальна сума податків на доходи фізичних осіб, на яку можна спиратися у розрахунку вигоди від трансферу податку для сільської місцевості, становить 29,1 млрд грн.

Треба визнати, що зазвичай не всі платники податку демонструють високу громадянську свідомість і готовність переадресовувати частину сплаченого податку будь-куди, а на користь громадської (некомерційної) організації й поготів. Міжна- 
родна практика свідчить, що зробити це воліють не більше 30-40 \% громадян. Своєю чергою, ми пропонуємо скоригувати суму потенційної вигоди від трансферу податку на рівень довіри населення України до громадських об'єднань, який регулярно відстежується в рамках соціологічних моніторингів. Тому реалістичнішим є розрахунок відповідно до формули:

$$
M=\text { RuralTax } \times r \times \text { Trust },
$$

де $M$ - сума мобілізованих коштів, RuralTax - сума податку на доходи фізичних осіб, працевлаштованих у сільській місцевості, $r$ - ставка, за якою здійснюється трансфер - 2 \%, Trust - частка респондентів, які довіряють громадським (некомерційним) організаціям та активістам.

За спостереженнями вітчизняних соціологів, у 2017 р. до 48 \% опитаних українців висловилися про довіру до громадських формувань [12]. Отже, мобілізовані кошти (M) у 2017 р. в Україні могли б утілитися в 279,4 млн грн. Для унаочнення значущості цієї суми скористаємося офіційними даними державних закупівель від порталу Prozorro. Одним із об’єктів, для яких здійснювалися закупівлі у 2017 р., стала середня школа в одному з сіл Рівненської області. Вартість необхідної реконструкції шкільної будівлі становила 52 млн грн [13]. Тому потенційно мобілізованих через відсоткову філантропію коштів у 2017 р. вистачило б для реконструкції майнового комплексу п’яти таких шкіл.

Нагадаємо також про способи безпосереднього бюджетного фінансування громадського сектору, які можуть прислужитися для фінансового забезпечення сільського розвитку в Україні. До них традиційно відносять пряме субсидіювання (утримання), державні закупівлі товарів і послуг громадських організацій, а також цільові гранти від публічної влади, що надаються на конкурсних засадах [14]. У європейських країнах (наприклад, в Австрії) кошти бюджету, надані у котрийсь із цих способів, становлять значну (іноді левову) частку у структурі доходів громадських формувань (50 \% і більше). Але, за аналізом фахівців, бюджетне фінансування громадського сектору в Україні неухильно зменшується, попри загальне зростання бюджетних видатків у країні [15]. Крім того, державна підтримка вітчизняного громадянського сектору ніколи не була значною. Тому марно сподіватися на великі обсяги публічних фінансів для підтримки громадських ініціатив у сільській місцевості.

Оцінюючи громадські джсерела фінансування сільського розвитку в Україні, варто вказати на краудфандинг, що має на меті здебільшого підтримку саме програмних / проектних ініціатив. Його суть - колективне внесення невеликих грошових сум значною кількістю осіб із використанням спеціалізованих інтернет-платформ на користь некомерційних соціальних і культурних ініціатив, а також - бізнес-стартапів і виробничих проектів. Умовно це - глобальна складчина, учасників якої (пересічних людей - бекерів) не пов'язують ні сталі особисті стосунки, ні спільний ареал (територія, країна) проживання, ні будь-який інший фактор, крім суб'єктивної зацікавленості конкретною ідеєю. Автор такої ідеї попередньо має зареєструватися на відповідному інтернет-ресурсі та структурно описати їі, аргументуючи обсяг і кожну позицію фінансової потреби. Зазвичай термін збору необхідної суми є обмеженим декількома тижнями, а платежі здійснюються в електронний спосіб. Якщо за його підсумками достатньої суми мобілізувати не вдалося, сплачені внески повертають усім учасникам, що зголосилися допомогти.

У світі нині відбувається краудфандинговий бум. Починаючи з 2011 р. обсяги краудфандингу щорічно подвоюються, у 2015 р. вони становили 35 млрд дол. США. 
Серед регіонів найбільшого зростання - Північна Америка, Південно-Східна Азія [16]. У мережі Інтернет функціонує близько півмільйона сучасних краудфандингових платформ. Напевне, найвідомішою є Kickstarter iз 14 млн учасників по всьому світові. Від моменту заснування у 2009 р. цією платформою було залучено приблизно 3,5 млрд дол. США і створено понад 300 тис. робочих місць. За мобілізовані тут кошти реалізовано близько 140 тис. технологічних, мистецьких і соціальних проектів. Серед них багато таких, що мають тематичний сільський фокус, у т. ч. сільськогосподарський, агропромисловий (наприклад, проекти, націлені на ефективне сумісне використання членами сільської громади родючих угідь на кооперативних засадах для вирощування фруктів, овочів і квітів).

Із Kickstarter змагається платформа Indiegogo, яку обрали 9 млн бекерів і де обсяг фінансування уже перевершив один мільярд дол. США. Позиціонуючи свої конкурентні переваги стосовно Kickstarter, платформа Indiegogo пропонує особам, що реєструють тут свої ідеї для збору коштів, додаткові сервіси (освітні, консультативні, маркетингові послуги перед стартом і після завершення краудфандингової кампанії). Indiegogo підтримує ідеї сільськогосподарського напряму. Наприклад, однією з успішних кампаній стала підтримка проекту розроблення та фермерського використання системи віртуальної огорожі для випасу тварин, що мінімізує затрати праці [17].

Піонером краудфандингу в Україні стала започаткована у 2012 р. інтернет-спільнотою «Велика ідея» платформа «Спільнокошт», де збирають кошти для проектів у сфері охорони здоров'я, освіти, літературних і журналістських проектів, для наукових досліджень. За час функціонування платформи мобілізовано більш як 13 млн грн для понад 200 ідей: середній розмір фінансової підтримки в розрахунку на один проект становив приблизно 65 тис грн. Однак є й такі проекти, автори котрих зібрали понад один мільйон гривень. Крім звичних для таких платформ можливостей збору коштів, «Спільнокошт» пропонує умови для краудфандингового фінансування діяльності неприбуткових організацій. На «Спільнокошті» можна віднайти чимало проектів із сільською тематикою. Вони націлені, наприклад, на розвиток сільського туризму, на навчання дітей сучасним технологіям у сільських школах тощо.

$\mathrm{Na}$-Starte - ще одна успішна українська платформа, заснована у 2014 р. Вона нагромаджує гроші для проектів у дуже різних тематичних категоріях. Серед іншого, $\mathrm{Na}$-Starte дає можливість реалізувати проекти, присвячені сільській проблематиці (зокрема, розвитку культурного простору сіл та ОТГ). Загалом на цій платформі зібрано понад чотири мільйони гривень. Її особливістю стала єдина в Україні безкоштовна школа краудфандингу, яка акумулює універсальні практичні поради і приклади 3 досвіду цього способу фінансування суспільно значущих ідей. Цим Na-Starte споріднена із зарубіжною платформою Indiegogo.

Не можна не згадати про спеціалізовану краудфандингову платформу для освітніх проектів GoFundEd, створену з метою допомогти ініціативним вчителям креативізувати навчальний контент і виховний простір для учнів. Чимало ідей надходить від представників сільських шкіл. Крім фінансових ресурсів, автори ідей отримують і організаційну підтримку.

Як бачимо, і в Україні краудфандинг активно розвивається, а інтернет-платформи відкриті для проектів з сільською тематикою. Разом із тим, доводиться рахуватися із несприятливими соціально-економічними умовами розвитку краудфандингу в Україні. Найбільшою проблемою є низький рівень доходів населення: громадяни часто виявляються орієнтованими переважно на поточне споживання і мало цікавляться інноваційними способами капіталовкладень. 
Але дослідники зазначають: криза в державі, перешкоджаючи повноцінному розвиткові краудфандингу, посилює його акценти саме на проектах соціального спрямування [18]. Тобто краудфандинг в Україні, ймовірно, нескоро сприйматиметься як напрям інвестиційної активності для заробітку, але як фінансовий важіль прискорення позитивних соціальних змін він вже зараз актуальний. Це надає реальної перспективи використанню вказаного інструменту для підтримки соціальної сфери у сільських громадах.

3 метою унаочнення потенціалу краудфандингу для активізації розвитку сільських територій пропонуємо розрахунок за формулою:

$$
K_{\text {fund }}=N_{\text {smart_user }} \times P_{\text {min }} \times \text { rest, }
$$

де $K_{\text {fund }}$ - загальна сума коштів, потенційно залучених через краудфандинг, $N_{\text {smart_user }}$ - кількість користувачів смартфонів в Україні (саме особи зі звичкою та навиком рутинного онлайн-доступу є найімовірнішими краудфандинг-донорами; крім того, смартфони самі собою є недешевими пристроями, тому певною мірою засвідчують фінансову змогу своїх власників бути такими донорами), $P_{\min }-$ підкреслено дріб'язковий (але регулярний) умовний внесок користувача смартфону на користь котроїсь із краудфандингових платформ, rest - кількість вихідних і святкових днів у році (адже участь у краудфандингу не має відволікати від робочих буднів).

Щодо першого параметру доцільно скористатися даними Міжнародної дослідницької компанії Newzoo, що вивчає світовий ринок відеоігор і презентувала у 2017 р. рейтинг 50 країн із найбільшою аудиторією користувачів смартфонів. В Україні такими виявилися 10448 тис. осіб [19].

При визначенні ймовірної кількості краудфандинг-донорів для проектів сільської тематики вимога щодо обов’язкового працевлаштування чи проживання донорів у сільській місцевості, за нашим баченням, не може бути жорсткою, позаяк краудфандинг-платформи є електронними (з відкритим доступом, необмеженим ні територіально, ні соціально). Проекти для краудфандингу орієнтуються на різних донорів, які можуть проживати і працювати у селі чи в місті. Важливо, щоб проектна пропозиція була цікавою в широкому сенсі. Саме тому для розрахунку суми коштів, потенційно залучених через краудфандинг у 2017 р. для сільського розвитку, пропонуємо брати до уваги загальну кількість користувачів смартфонів.

Показник rest має відображати дані про вихідні дні і свята у 2017 р. Їх налічувалося 120 - відповідно до національного календаря робочих днів. Значенням умовного краудфандингового внеску може бути ціна хвилини розмови згідно з тарифами одного із вітчизняних операторів стільникового зв'язку $(0,5$ грн - на номери мереж операторів-конкурентів). Отже, через краудфандинг в Україні у 2017 р. можна було б акумулювати 627 млн грн для потреб розвитку сільських територій, якби українські власники смартфонів на дозвіллі (у вихідні та святкові дні) витрачали з цією метою 50 копійок у день. Акумульована сума дала б змогу придбати 397 шкільних автобусів для сільських громад (якщо відштовхуватися від вартості такого автобуса у 1,58 млн грн, заявленої в одному із оголошень на порталі Prozorro).

Додатковим аргументом на користь краудфандингу для сільського розвитку є глобальний простір краудфандингового фінансування: українські проекти безперешкодно можуть залучати кошти на міжнародних краудфандингових майданчиках. I такі проекти вже стали реальністю: у 2017 р. понад 30 ідей вітчизняних новаторів презентовано на великих платформах - Kickstarter та Indiegogo, де вони зібрали внесків на суму близько 2 млн дол. США [20]. 
Висновки. Фінансово-організаційна участь громадських інститутів є перспективним напрямом забезпечення соціальної сфери сільських територій з огляду на зростання значення і помітний соціально-економічний вплив громадянського суспільства в Україні. Фінансування сільського розвитку на засадах широкого залучення цих інститутів має характеризуватися переважно громадським спрямуванням бюджетних коштів і коштів соціально відповідального бізнесу, рівно як і посиленням акцентів на громадських фінансових джерелах. Такі джерела не можуть бути єдиними чи пріоритетними. Проте їхня присутність та активне використання є бажаними, бо урізноманітнюють та осучаснюють ресурсні спроможності фінансового забезпечення соціальної сфери села.

Фінансування за участю громадських інститутів зосереджує кошти, передусім, на проектних ініціативах організацій громадянського суспільства. Крім того, воно враховує ресурсний потенціал таких новітніх фінансових інструментів як соціальні облігації, трансфер податку на доходи фізичних осіб, а також краудфандинг. Для активізації цих інструментів необхідно накопичувати практичний досвід реалізації соціальних інвестицій вітчизняного бізнесу у партнерстві із громадським сектором. Треба усвідомлювати, що загалом вітчизняний комерційний сектор досі не став активним учасником подолання соціальних проблем, посилаючись на загальні труднощі ділової активності в країні. Водночас варто пригадати значні масштаби фінансової мобілізації суспільства (у т. ч. бізнесу) для забезпечення української армії, яке стало гострою потребою з 2014 р. Це дає підстави говорити про реальні перспективи приватних соціальних інвестицій в Україні, виносячи за дужки дійсні стійкі недоліки регуляторної та фіскальної державної політики.

Необхідно також удосконалити порядок адміністрування податку на доходи фізичних осіб, передбачивши право пересічного платника податку переадресувати певний встановлений законом відсоток суми цього податку до організації, яка декларує соціальні цілі розвитку села. Це, ймовірно, слугуватиме додатковим чинником згуртування сільських мешканців для боротьби за власний добробут, а також інтенсифікує діалог громадянського суспільства і сільських громад.

На часі - створення умов для залучення пересічних громадян до фінансування соціальних ініціатив через сучасні цифрові краудфандингові майданчики. Зростанню зацікавленості такими новітніми інструментами фінансування не сприяє суспільно-політична нестабільність у країні внаслідок порушення національних кордонів і зовнішньої агресії. Проте соціальні пріоритети вітчизняного краудфандингу залишаються вкрай доречними, і це доцільно використати в контексті диверсифікації фінансових джерел соціального розвитку села.

Виконанне дослідження відкриває перспективи подальших розвідок у цьому напрямі, зокрема, щодо здійснення оцінки загальних потреб (суми) мобілізації коштів, достатніх для фінансування соціального розвитку села в Україні за певний період і в середньому за рік; щодо обгрунтування частки потреби, яку можуть забезпечити громадські джерела за відповідального вибору цільового спрямування (тематики потреб); щодо визначення потенційної суми мобілізації громадського фінансування всіма інструментами - загалом і, зокрема, на сільські проекти. Майбутні дослідження доцільно також скерувати у напрямі пошуку можливостей системного узгодження нових для України громадських і традиційних бюджетно-розпорядчих джерел фінансування соціального розвитку села. 


\section{ЛІТЕРАТУРА}

1. Трансформація сільського розселення в Україні: / за ред. Т.А. Заяць; Ін-т демографії та соціальних досліджень імені М.В. Птухи НАН України. - Київ, 2017. - 298 с.

2. Дяконенко О.І. Вплив фінансової децентралізації на розвиток сільських поселень в Україні // Демографія та соціальна економіка. - 2018. - № 3 (34). - С. 161-174. - https://doi.org/ 10.15407/dse2018.03.161

3. Звонар В.П. Громадянське суспільство як агент соціально-економічного впливу в Україні // Демографія та соціальна економіка. - 2017. - № 2 (30). - С. 138-151. - https://doi.org/ $10.15407 /$ dse2017.02.138

4. Волосевич I., Коноплицька T., Костюченко T., Марценюк T. Комплексне дослідження становища жінок, які проживають у сільській місцевості. - Київ: ВАITE, 2015. - С. 87-88.

5. Іртищева I.О., Біліченко О.С. Громадські організації - важливий елемент реалізації соціальних проектів для сільської молоді // Агросвіт. - 2012. - № 14. - С. 6-7.

6. Coble W. Health Impact Bonds: Removing the Legal Barriers // University of Pittsburgh Law Review. 2014. - Vol. 76. - P. 113- 130.

7. Introduction and guidance to developing Social Impact Bonds, information about sources of funding and available support. Published 16 November 2012 / UK Government services and information. [Електронний ресурс]. - Режим доступу: https://www.gov.uk/guidance/social-impact-bonds\#history (дата звернення: 20.09.2017).

8. Свинчук А.А. Соціальні облігації як фінансовий інструмент розвитку соціальних підприємств в Україні // Наука й економіка. - 2015. - № 2. - С. 7-12.

9. Штибель У.І. Формування соціально-орієнтованої банківської системи в Україні: дис... канд. екон. наук, спец. 08.00.08. - Львів, 2016. - 262 с.

10. Куц С. Відсоткова філантропія. Аналітична записка за результатами аналізу державної політики в галузі фінансування організацій громадянського суспільства / ГО «Центр філантропії». - Київ, 2006. [Електронний ресурс]. - Режим доступу: http://www.philanthropy.org.ua/filestorage/File/ Onepercent-brief.htm (дата звернення: 16.08.2017).

11. Ткачук I. Я. Відсоткова філантропія як метод залучення додаткових фінансових ресурсів громадськими організаціями України // Інноваційна економіка. - 2013. - № 2. - С. 298-303.

12. Ставлення громадян України до суспільних інститутів, електоральні орієнтації / Центр Разумкова. Соціологія. - 2017. - 23 жовтня [Електронний ресурс]. - Режим доступу: http://razumkov. org.ua/napriamky/sotsiologichni-doslidzhennia/stavlennia-hromadian-ukrainy-do-suspilnykh-instytutiv-elektoralni-oriientatsii-2 (дата звернення: 16.02.2018).

13. Prozorro. Публічні закупівлі [Електронний ресурс]. - Режим доступу: https://prozorro.gov.ua/ plan/UA-P-2019-01-28-006305-а (дата звернення: 16.02.2019)

14. Горєлов Д. Державне фінансування громадських організацій: зарубіжний досвід та рекомендації щодо впровадження в Україні: аналітична записка / Нац. ін-т стратегічних досліджень. - Київ, 2012 [Електронний ресурс]. - Режим доступу: http://www.niss.gov.ua/articles/811 (дата звернення: 12.11.2017).

15. Існуючі механізми співпраці органів державної влади з організаціями громадянського суспільства в контексті реалізації Національної стратегії сприяння розвитку громадянського суспільства в Україні 2016-2020. - Київ, 2016. - 280 с.

16. Crowdfunding industry statistics. [Електронний ресурс]. - Режим доступу: http://crowdexpert. com/crowdfunding-industry-statistics (дата звернення: 21.09.2017).

17. Nofence - the virtual fence for grazing animals / INDIEGOGO [Електронний ресурс]. - Режим доступу: https://www.indiegogo.com/projects/nofence-the-virtual-fence-for-grazing-animals\#/ (дата звернення: 22.02.2019).

18. Ткачук І.Я. Краудфандинг в контексті залучення додаткових ресурсів для реалізації проектів державно-приватного партнерства // Інноваційна економіка. - 2016. - № 5-6. - С. 183-186.

19. Top 50 countries by smartphone users and penetration / NEWZOO. [Електронний ресурс]. - Режим доступу: https://newzoo.com/insights/rankings/top-50-countries-by-smartphone-penetration-andusers (дата звернення: 27.12.2017). 
20. Оліярник М. Веселі старти. Скільки українці заробляють на Kickstarter i Indiegogo // Новое время. - 2017. - 15 вересня [Електронний ресурс]. - Режим доступу: https://nv.ua/ukr/techno/ made-in-ukraine/u-2017-rotsi-ukrajintsi-zibrali-na-kickstarter-i-indiegogo-majzhe-2-mln-1855730. html (дата звернення: 16.02.2018).

\section{REFERENCES}

1. Zaiats, T.A. (Eds). (2017). Transformatsiia sil's'koho rozselennia v Ukraini [Transformation of rural settlements in Ukraine]. Kyiv: Ptoukha Institute for Demography and Social Studies of the National Academy of Sciences of Ukraine. [in Ukrainian].

2. Diakonenko, O.I. (2018). Vplyv finansovoi detsentralizatsii na rozvytok sil's'kykh poselen' v Ukraini [Influence of financial decentralization on the development of rural settlements in Ukraine]. Demohrafiia ta sotsial'na ekonomika - Demography and Social Economy, 3(34), 161-174. [in Ukrainian]. - https://doi. org/10.15407/dse2018.03.161

3. Zvonar, V.P. (2017). Hromadians'ke suspil'stvo iak ahent sotsial'no-ekonomichnoho vplyvu v Ukraini [Civil society as an socio-economic actor in Ukraine]. Demohrafiia ta sotsial'na ekonomika - Demography and Social Economy, 2(30), 138-151. [in Ukrainian]. - https://doi.org/10.15407/dse2017.02.138

4. Volosevych, I., Konoplyts'ka, T., Kostiuchenko, T., \& Martseniuk, T. (2015). Kompleksne doslidzhennia stanovyscha zhinok, iaki prozhyvaiut' u sil's'kij mistsevosti [Comprehensive study of the situation of women living in rural areas]. Kyiv: VAITE [in Ukrainian].

5. Irtyscheva, I.O., \& Bilichenko, O.S. (2012). Hromads'ki orhanizatsii - vazhlyvyj element realizatsii sotsial'nykh proektiv dlia sil's'koi molodi [Civil society organizations as an important element in implementing of social projection of rural youth]. Ahrosvit - Agroworld, 14, 6-7 [in Ukrainian].

6. Coble, W. (2014). Health Impact Bonds: Removing the Legal Barriers. University of Pittsburgh Law Review, 76, 113-130.

7. Introduction and guidance to developing Social Impact Bonds, information about sources of funding and available support. (2012). UK Government services and information. Retrieved from https://www.gov. uk/guidance/social-impact-bonds\#history

8. Svynchuk, A.A. (2015). Sotsial'ni oblihatsii iak finansovyj instrument rozvytku sotsial'nykh pidpryiemstv v Ukraini [Social Bonds as a Financial Instrument for the Development of Social Enterprises in Ukraine]. Nauka jekonomika - Science and Economics, 2, 7-12 [in Ukrainian].

9. Shtybel', U.I. (2016). Formuvannia sotsial'no-oriientovanoi bankivs'koi systemy v Ukraini [Formation of socially oriented banking system in Ukraine]. L'viv [in Ukrainian].

10. Kuts, C. (2006). Vidsotkova filantropiia. Analitychna zapyska za rezul'tatamy analizu derzhavnoi polityky $v$ haluzi finansuvannia orhanizatsij hromadians'koho suspil'stva [Tax philanthropy. Analytical report on the public policy of financing of civil society organizations]. Kyiv: Philanthropy Center. Retrieved from http://www.philanthropy.org.ua/filestorage/File/Onepercent-brief.htm [in Ukrainian].

11. Tkachuk, I.Ya. (2013). Vidsotkova filantropiia iak metod zaluchennia dodatkovykh finansovykh resursiv hromads'kymy orhanizatsiiamy Ukrainy [Tax philanthropy as an auxiliary financial resource for civil society organizations in Ukraine]. Innovatsijna ekonomika - Innovative economy, 2, 298-303 [in Ukrainian].

12. Stavlennia hromadian Ukrainy do suspil'nykh instytutiv, elektoral'ni oriientatsii [The Attitudes of Ukrainian Citizens to Public Institutions, Electoral Orientations. (2017). Kyiv: Razumkov Center. Retrieved from http://razumkov.org.ua/napriamky/sotsiologichni-doslidzhennia/stavlennia-hromadian-ukrainy-dosuspilnykh-instytutiv-elektoralni-oriientatsii-2 [in Ukrainian].

13. Prozorro. Public procurements. Retrieved from: https://prozorro.gov.ua/plan/UA-P-2019-01-28006305-a [in Ukrainian].

14. Horielov, D. (2012). Derzhavne finansuvannia hromads'kykh orhanizatsij: zarubizhnyj dosvid ta rekomendatsii schodo vprovadzhennia $v$ Ukraini: analitychna zapyska [Public funding of non-governmental organizations: foreign experience and recommendations for implementation in Ukraine: analytical report]. Kyiv: The National Institute for Strategic Studies. Retrieved from http://www.niss.gov.ua/articles/811 [in Ukrainian].

15. Isnuiuchi mekhanizmy spivpratsi orhaniv derzhavnoi vlady z orhanizatsiiamy hromadians'koho suspil'stva $v$ konteksti realizatsii Natsional'noi stratehii spryiannia rozvytku hromadians'koho suspil'stva v Ukraini 
2016-2020 [Existing mechanisms of cooperation between public authorities and civil society organizations in the context of the implementation of the National Strategy for Promoting Civil Society in Ukraine 20162020]. (2016). Kyiv [in Ukrainian].

16. Crowdfunding industry statistics. Retrieved from http://crowdexpert.com/crowdfunding-industrystatistics

17. Nofence - the virtual fence for grazing animals (n.d.). INDIEGOGO. Retrieved from https://www.indiegogo.com/projects/nofence-the-virtual-fence-for-grazing-animals\#/

18. Tkachuk, I.Ya. (2016). Kraudfandynh v konteksti zaluchennia dodatkovykh resursiv dlia realizatsii proektiv derzhavno-pryvatnoho partnerstva [Crowdfunding in the context of mobilizing of auxiliary resources for the implementation of public-private partnership projects]. Innovatsijna ekonomika - Innovative economy, 5-6, 183-186 [in Ukrainian].

19. Top 50 countries by smartphone users and penetration. NEWZOO. Retrieved from https://newzoo.com/ insights/rankings/top-50-countries-by-smartphone-penetration-and-users

20. Oliiarnyk, M. (2017). Veseli starty. Skil'ky ukraintsi zarobliaiut' na Kickstarter i Indiegogo [ready, steady, go! Ukrainians make money on Kickstarter and Indiegogo]. Novoe vremia - Newtime. Retrieved from https://nv.ua/ukr/techno/made-in-ukraine/u-2017-rotsi-ukrajintsi-zibrali-na-kickstarter-i-indiegogomajzhe-2-mln-1855730.html [in Ukrainian].

Стаття надійшла до редакції журналу 09.04.2019. 


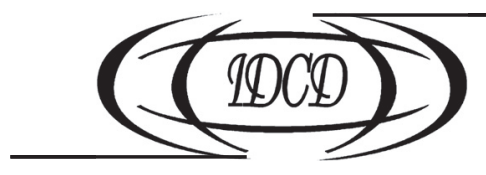

https://doi.org/10.15407/dse2019.02.137

УДК 332.8, 365, 728

JEL CLASSIFICATION: I30, L74, R31

\section{В.С. ЗАЯЦЬ}

канд. екон. наук., старш. наук. співроб.

старш. наук. співроб.

Інститут демографії та соціальних

досліджень ім. М.В. Птухи НАН України

01032, Україна, м. Київ, бул. Т. Шевченка, 60

E-mail: zayac@idss.org.ua

ORCID 0000-0001-5757-9613

\section{РОЗВИТОК ЖИТЛОВОГО БУДІВНИЦТВА ЯК ФАКТОР ФОРМУВАННЯ ЖИТЛОВИХ УМОВ НАСЕЛЕННЯ}

Досліджено сучасні тенденції розвитку житлового будівництва України в умовах істотного впливу системних соціально-економічних негараздів та чинників нестабільності. Виявлено низьку ефективність фінансово-кредитних механізмів, необхідних для вирішення житлових проблем населення та недостатню активність державних структур у сфері нового будівництва та модернізації застарілого житлового фонду. Встановлено, що потреба у доступному житлі залишається в країні доволі високою через незадовільні умови проживання населення, низькі стандарти житлової забезпеченості та якість житлових приміщень. Житлова проблема в Україні не знаходить вирішення протягом багатьох років, зберігаються високі соціальні очікування щодо цього у зв'язку з необхідністю оновлення житлового фонду. Попри зростання деяких показників житлової забезпеченості, в Україні зберігається значно вищий рівень перенаселеності житлових приміщень у порівнянні з краӥнами СС. Визначено, що нестабільність макроекономічної ситуації в країні, значні боргові зобов'язання перед європейськими партнерами стримують розвиток ринку нерухомості та модернізацію застарілого житла. Проте сучасне житлове будівництво розвивається завдяки поєднанню різних технологій, зростанню заінтересованості інвесторів у новому будівництві. У зв'язку з иим досліджено специфіку сучасних технології будівництва висотних будинків (цегляне, панельне, монолітно-каркасне, монолітне та збірне монолітно-каркасне) як фактору формування житлових умов населення, виявлено їхні переваги та недоліки в аспекті основних технічних і вартісних характеристик, а також доцільних сфер застосування. Визначено напрями розвитку житлового будівництва, зміни основних параметрів житла та рівня забезпечення ним населення краӥни. Узагальнено та систематизовано європейський досвід житлового будівництва та можливі джерела стимулювання його розвитку. Виявлено зміни на ринку нерухомості України за останні роки, насамперед у сегменті первинної нерухомості, зокрема зростання середньої житлової та загальної площі нових багатоповерхових забудов, підвищення інтересу інвесторів до зведення нових житлових комплексів. Установлено, що найвищі темпи введення в експлуатацію житлової нерухомості зберігаються у Києві та Київській області, містах Одесі та Львові. Розглянуто проблеми енергоефективності та екологічності будівництва в контексті можливостей поліпшення житлових умов населення, визначено напрями й шляхи їхнього розв'язання.

Ключові слова: житлове будівництво, житлові умови, населення, технології будівництва, енергоефективність.

(C) ЗАЯЦЬ В.С., 2019 
В.С. Заяи

канд. экон. наук., старш. науч. сотр., старш. науч. сотр.

Институт демографии и социальных исследований

им. М.В. Птухи НАН Украины

01032, Украина, г. Киев, бул. Т. Шевченко, 60

E-mail: zayac@idss.org.ua

ORCID 0000-0001-5757-9613

\section{РАЗВИТИЕ ЖИЛИЩНОГО СТРОИТЕЛЬСТВА КАК ФАКТОР ФОРМИРОВАНИЯ ЖИЛИЩНЫХ УСЛОВИЙ НАСЕЛЕНИЯ}

Исследованы современные тенденции развития жилищного строительства Украины в условиях существенного влияния системных социально-экономических проблем и факторов нестабильности. Выявлена низкая эффективность финансово-кредитныхмеханизмов, необходимых для решения жилищных проблем населения и недостаточная активность государственных структур в сфере нового строительства и модернизации устаревшего жилого фонда. Установлено, что потребность в доступном жсилье остается в стране достаточно высокой из-за неудовлетворительных условий проживания населения, низких стандартов жилищной обеспеченности и качества жилых помещений. Жилищная проблема в Украине не находит решения в течение многих лет, сохраняются высокие социальные ожидания относительно этого в связи с необходимостью обновления жилого фонда. Несмотря на рост некоторых показателей жилищной обеспеченности, в Украине сохраняется более высокий уровень перенаселенности жилых помещений по сравнению со странами ЕС. Определено, что нестабильность макроэкономической ситуации в стране, значительные долговые обязательства перед европейскими партнерами сдерживают развитие рынка недвижимости и модернизацию устаревщего жилья. Однако современное жилищное строительство развивается благодаря сочетанию разных технологий, росту заинтересованности инвесторов в новом строительстве. В связи с этим исследована специфика современных технологий строительства высотных домов (кирпичное, панельное, монолитно-каркасное, монолитное и сборное монолитно-каркасное) как фактора формирования жсилищных условий населения, выявлены их преимущества и недостатки в аспекте основных технических и стоимостных характеристик, а также целесообразных областей применения. Определены направления развития жилищного строительства, а также изменения отдельных параметров жилья и уровня обеспечения им населения страны. Обобщены и систематизированы европейский опыт жилищного строительства и возможные источники стимулирования его развития. Выявлены изменения на рынке недвижимости Украины за последние годы, прежде всего в сегменте первичной недвижимости, в частности рост средней жилой и общей площади новых многоэтажных застроек, повышение интереса инвесторов к строительству новых жилых комплексов. Установлено, ито высокие темпы ввода в эксплуатацию жилой недвижимости сохраняются в Киеве и Киевской области, городах Одессе и Львове. Рассмотрены проблемы энергоэффективности и экологичности строительства в контексте возможностей улучшения жилищных условий населения, определены направления и пути их решения.

Ключевые слова: жилищное строительство, жилищные условия, население, технологии строительства, энергоэффективность.

\section{V.S. Zaiats}

$\mathrm{PhD}$ in Economics, Senior Researcher

Ptoukha Institute for Demography

and Social Studies of the National Academy of Sciences of Ukraine,

01032, Ukraine, Kyiv, Taras Shevchenko Blvd., 60

E-mail: zayac@idss.org.ua

ORCID 0000-0001-5757-9613

\section{HOUSING CONSTRUCTION DEVELOPMENT AS A FACTOR OF FORMATION OF HOUSING CONDITIONS OF POPULATION}

The modern tendencies of developing housing construction of Ukraine in the conditions of significant influence of systemic socio-economic disadvantages and instability factors are investigated. The low effectiveness of financial 
and credit mechanisms necessary for solving residential problems of the population and the lack of activity of state structures in the field of new construction and modernization of an outdated housing stock are identified. It is established that the need for affordable housing remains rather high in the country due to unsatisfactory living conditions of the population, low standards of housing supply and quality of residential premises. The housing problem in Ukraine has not been resolved for many years, high social expectations for this are due to the need to upgrade the housing stock. Despite the growing dynamics of certain indicators of housing supply, Ukraine still has a significantly higher level of overpopulation of residential premises compared to EU countries. It is determined that instability of the macroeconomic situation in the country, significant debt obligations to European partners restrain the development of the real estate market and the modernization of outdated housing. However, modern housing construction is developing due to the combination of different technologies, growth of interest of investors in new construction. In connection with this, the specifics of modern technologies for the construction of high-rise buildings (brick, panel, monolithic-frame, monolithic and prefabricated monolithic-frame) are investigated as the factor for the formation of housing conditions of the population, their advantages and disadvantages in terms of the main technical and cost characteristics, and also reasonable areas of application. Ranking of modern technologies of housing construction is carried out at the cost of materials and the prospects of their application are determined. The main indicators characterizing the directions of development of housing construction, as well as the separate price parameters of housing and the level of maintenance of the population of the country are carried out. The European experience of housing construction and possible sources of stimulation of its development are summarized and systematized. The changes in the real estate market of Ukraine in recent years are identified, first of all in the segment of primary real estate, in particular, the growth of the average residential space and the total area of new multi-storey buildings, increased interest of investors in the construction of new residential complexes. It is established that the highest rates of commissioning of residential real estate are maintained in Kyiv and Kyiv region, cities of Odessa and Lviv. The problems of energy efficiency and environmental friendliness of construction in the context of possibilities of improvement of living conditions of the population are considered, directions and ways of their solution are determined.

Keywords: housing construction, housing conditions, population, construction technologies, energy efficiency.

Постановка проблеми та актуальність дослідження. Під впливом суспільних еволюційних змін поступово трансформуються уявлення про перспективні напрями розвитку житлового будівництва, якість житла, його основне функціональне призначення і рівень комфортності. Першопричиною цих змін є розвиток суспільних відносин, притаманних різним соціально-економічним системам, а також найбільш впливових на формування житлових умов населення секторів економіки. Поряд із іншим, житлове будівництво стимулює підвищення якості життя населення, впливає на темпи інфляції та безробіття, а головне - залучає довгострокові інвестиції в поліпшення житлових умов населення.

Актуалізація наукової проблематики, пов'язаної із визначенням взаємовпливу тенденцій розвитку будівництва і житлової сфери, обумовлена такими причинами. По-перше, в Україні, поряд із іншими постсоціалістичними країнами, залишаються незадовільними умови проживання населення через низькі стандарти забезпеченості житловим простором, низьку якість житлових приміщень та неефективну державну житлову політику. По-друге, незважаючи на поліпшення середніх показників житлового забезпечення протягом останніх років, значно вищим у порівнянні з країнами ЄC є рівень перенаселеності житла, насамперед, у сімей з дітьми. По-третє, надзвичайно повільно підвищується рівень комфортності більшості житлових помешкань, високою залишається частка зношеного житлового фонду.

Формування якісно нових житлових умов населення в країні залежить від дієвості системних чинників, серед яких: тенденції розвитку будівництва, окремих сегментів ринку нерухомості та поведінка й наміри його основних учасників; обсяги капіталу, швидкість його обігу на ринку первинної та вторинної нерухомості, у тому числі іпотечного кредитування житла; купівельна спроможність населення, його наміри 
інвестувати в об’єкти нерухомості; житлова політика держави та місцевої влади, іiі цільові орієнтири та інструменти вирішення проблем у цій сфері.

Ураховуючи мультиплікативний ефект житлового будівництва, його вагомий вплив на інші сфери економічної діяльності та умови життя населення, можна передбачити посилення цих залежностей. За сучасних соціально-економічних умов основні обмеження щодо поліпшення житлових умов населення формуються через розрив між реальними доходами більшості громадян та цінами на житлові об'єкти, а також низький рівень конкуренції на ринку нерухомості. Ситуацію значно погіршують процеси нерівномірності розвитку його сегментів у регіонах, недостатні обсяги введення в експлуатацію об'єктів муніципального фонду та соціального житла. Враховуючи незадовільні житлові умови значної частки населення, низький рівень його фінансової спроможності у вирішенні житлових проблем і налаштованість на їхнє поліпшення власними силами, можна очікувати, що зміна ситуації на краще потребуватиме тривалого часу.

Аналіз останніх досліджень і публікацій. Сучасні наукові дослідження з проблем розвитку житлового будівництва та формування комфортних житлових умов населення активно розгортаються у міждисциплінарному контексті. Вагомі наукові здобутки досягнуто вітчизняними та зарубіжними вченими, серед яких відомі українські дослідники В. Близнюк (V. Blyznyuk), Е. Лібанова (Е. Libanova), О. Макарова (O. Makarova), В. Новіков (V. Novikov). Проте домінують напрями наукових досліджень, в яких житлове будівництво розглядається здебільшого як складова господарського комплексу країни, розвиток якої залежить від макроекономічної ситуації в країні і водночас впливає на неї, стимулюючи розвиток інших галузей економіки. Деякі аспекти розвитку житлового будівництва, його впливу на умови проживання населення представлено у дослідженнях галузевого спрямування.

У сучасній науковій літературі найбільшого опрацювання набули прикладні засади розвитку житлового будівництва, присвячені формуванню збалансованого ринку нерухомості під впливом взаємодії попиту, пропозиції та ціни житла. Значну увагу акцентовано на проблемах енергоефективності житлового будівництва у контексті завдань підвищення ефективності національної економіки [1]. Соціальні аспекти формування житлових умов населення грунтовно досліджено науковцями Інституту демографії та соціальних досліджень імені М.В. Птухи НАН України, насамперед Л. Черенько (L. Cherenko) [2], С. Поляковою (S. Polyakova), A. Реут (A. Reut) [3], В. Шишкіним (V. Shishkin) та ін. Серед їхніх наукових праць становлять інтерес дослідження, в яких розкрито вплив процесів соціальної стратифікації на зміну житлових потреб різних верств населення та модель їхньої поведінки, а також уявлення про прийнятні житлові стандарти [2, 3]. Вагоме соціальне значення мають результати наукових досліджень, спрямованих на виявлення можливостей імплементації європейських норм забезпечення соціальним житлом та реалізації цих прав в Україні [4].

Наукова новизна полягає в обгрунтуванні залежності між особливостями розвитку житлового будівництва в Україні й європейських країнах та якісними характеристиками житлових умов населення і динамікою розвитку ринку нерухомості в країні, а також виявленні суперечностей між інтересами населення та забудовниками.

Мета статті полягає у визначенні впливу основних тенденцій розвитку сучасного житлового будівництва з погляду його технологічних і конструктивних особливостей, можливостей модернізації та залучення нових інвестицій у різні сектори ринку нерухомості на характеристики житлових умов населення в контексті завдань поліпшення якості життя населення та наближення його до європейських стандартів. 
Методи дослідження грунтуються на засадах системного підходу, які передбачають установлення найістотніших залежностей у досліджуваній сфері. Застосовуваний порівняльний аналіз дав змогу виявити переваги і недоліки різних технологій сучасного житлового будівництва, а також відмінності у тенденціях його розвитку в Україні та європейських країнах із погляду інтересів споживачів у комфортному та екологобезпечному житловому просторі. На основі регіонального аналізу здійснено оцінку активності учасників первинного і вторинного сегментів ринку нерухомості в областях України. Новітні тенденції на ринку житлової нерухомості проілюстровано з використанням кейс-методу на прикладі столиці України. За останні роки, на жаль, значно звужено доступну статистичну базу щодо інформації стосовно введених в експлуатацію нових житлових будинків за використаними стіновими матеріалами, а також розподілу збудованих квартир за кількістю кімнат.

Виклад основного матеріалу і результатів дослідження. За будь-яких умов житло є одним з основних матеріальних благ, необхідних для успішної організації життєдіяльності людини та реалізації іiі життєвих цілей. Потреба в житлі є базовою, вона виникає з народження людини і зберігає вагоме значення протягом усього життя, а його основні характеристики є індикаторами якості життя. Житлові умови населення залежать від тенденцій розвитку житлового будівництва, його орієнтації на потреби споживачів та збалансованості розвитку ринку житлової нерухомості. Нормативноправовою основою регулювання житлових проблем в Україні є Конституція України, Житловий Кодекс України, Закони України «Про житловий фонд соціального призначення» від 13.10.2018 №3334-IV, «Про приватизацію державного житлового фонду» від 25.07.2018 №2482-ХІІ та ін. Основи стандартизації якості житла в Україні визначає «Єдиний класифікатор житлових будинків». У руслі цих документів головними критеріями оцінки комфортності житла $є$ організація його внутрішнього простору, параметри якості будівництва і будівельних конструкцій, а також обладнання й інженерного забезпечення [5].

Наразі зміни в житлових умовах населення України відбуваються під впливом соціально-економічних негараздів та чинників нестабільності. Дається взнаки обмеження сфери дії тих фінансово-кредитних механізмів, які зазвичай залучають на державному рівні для вирішення гострих житлових проблем населення, насамперед механізму іпотечного кредитування. В умовах зростання собівартості будівництва знижується активність державних і комерційних структур у сфері нового житлового будівництва та уповільнюються темпи модернізації застарілого житлового фонду. Загострення житлової проблеми в Україні обумовлює появу нових соціальних очікувань у зв’язку з процесами децентралізації на тлі бюджетних обмежень, нестабільності національної грошової одиниці та значного зниження купівельної спроможності населення. За сучасних соціально-економічних умов потреба у доступному житлі залишається в країні доволі високою внаслідок низького рівня житлової забезпеченості населення, відсутності ринку муніципального орендного житла. В цілому ринок житла країни не відповідає вимогам розвинутого ринкового середовища, оскільки перебуває під впливом інфляційних процесів, монополізації економіки, нестабільності фондового ринку та невизначеності перспектив економічного зростання. Високі боргові зобов'язання країни перед європейськими партнерами лише погіршують ситуацію.

На тлі прискореного зростання загальної чисельності населення та високого техногенного навантаження на навколишнє середовище постають нові завдання, пов'язані з необхідністю прискорення економічно вигідного та екологічно безпечного 
Таблиця 1. Переваги та недоліки сучасних технологій житлового будівництва

\begin{tabular}{|l|l|l|}
\hline \multicolumn{1}{|c|}{ Технології } & \multicolumn{1}{|c|}{ Переваги } & \multicolumn{1}{|c|}{ Недоліки } \\
\hline Панельна & $\begin{array}{l}\text { Відносна швидкість зведення та де- } \\
\text { шевизна; не поступаються цегляним } \\
\text { і монолітно-каркасним будинкам за } \\
\text { тепло- й звукоізоляційними характе- } \\
\text { ристиками }\end{array}$ & $\begin{array}{l}\text { Однотипні архітектурні й плану- } \\
\text { вальні рішення; перепланування } \\
\text { квартир неможливе; стіни не «ди- } \\
\text { хають» }\end{array}$ \\
\hline $\begin{array}{l}\text { збірна моно- } \\
\text { літно-кар- } \\
\text { касна }\end{array}$ & $\begin{array}{l}\text { Можливість вибору матеріалів зов- } \\
\text { нішніх та внутрішніх стін; швидкість і } \\
\text { дешевизна будівництва; низька матеріа- } \\
\text { ломісткість }\end{array}$ & $\begin{array}{l}\text { Придатність для серійного будів- } \\
\text { ництва; забудовнику необхідно мати } \\
\text { власне виробництво залізобетонних } \\
\text { конструкцій }\end{array}$ \\
\hline $\begin{array}{l}\text { Монолітно- } \\
\text { каркасна }\end{array}$ & $\begin{array}{l}\text { Сейсмостійкість та довговічність; мож- } \\
\text { ливість перепланування; відносно ви- } \\
\text { сокі темпи зведення висотних будинків } \\
\text { (понад 25 поверхів); широкий простір } \\
\text { для архітектурних та дизайнерських } \\
\text { рішень }\end{array}$ & $\begin{array}{l}\text { Низька звукоізоляція; відсутня нор- } \\
\text { мативна база для зведення будинків } \\
\text { понад 25 поверхів; висока вартість } \\
\text { будівництва, що перевищує 16 по- } \\
\text { верхів; низький рівень екологічності }\end{array}$ \\
\hline Монолітна & $\begin{array}{l}\text { Можливість втілення нових архітектур- } \\
\text { них рішень та ідей }\end{array}$ & $\begin{array}{l}\text { Будівельна конструкція масивна; } \\
\text { висока матеріалоємність, будинок } \\
\text { потребує утеплення }\end{array}$ \\
\hline Цегляна & $\begin{array}{l}\text { Високі параметри надійності, довговіч- } \\
\text { ності та екологічності; широкий про- } \\
\text { стір для дизайнерських ідей; стійкість } \\
\text { до пожеж }\end{array}$ & $\begin{array}{l}\text { Тривале будівництво, що усклад- } \\
\text { нюється в зимовий період; висока } \\
\text { вартість будівництва та внутрішньо- } \\
\text { го оздоблення }\end{array}$ \\
\hline
\end{tabular}

Джерело: складено за [6].

будівництва з використанням нових технологій і матеріалів, інженерних конструкцій і споруд. Тим самим змінюється матеріальна основа житлових умов населення, вона стає різноманітнішою завдяки комплексному поєднанню різних технологій і матеріалів, серед яких цегляне, панельне, монолітно-каркасне, монолітне та збірне монолітно-каркасне будівництво. Кожне з них має певну сферу й умови застосування, переваги і недоліки (табл. 1).

Технологічна основа будівництва формує основні характеристики житла - освітлення, інсоляція, радіаційний фон, рівень шуму, а також можливі екологічні ризики. Широке застосування в сучасному житловому будівництві таких основних матеріалів, як цегла, бетон і залізобетон зумовлене їхніми високими фізико-механічними властивостями, насамперед довговічністю та можливістю зведення різноманітних будівельних конструкцій та архітектурних форм. Поєднання різних способів виконання будівельних робіт (бетонні й залізобетонні конструкції поділяють на збірні, монолітні та збірно-монолітні) дає відчутний економічний ефект. Зокрема, будівництво з монолітного бетону і залізобетону економічно вигідне, потребує значно менших енергетичних та матеріальних витрат. Проте воно не завжди відповідає вимогам екологічності, а це один з важливих критеріїв якості житлових умов населення. Суперечність здебільшого вирішується на користь економічного, а не соціального ефекту, обумовленого зниженням рівня електромагнітного випромінювання, забруднення, шуму та вібрації.

Вплив розвитку будівництва на формування житлових умов населення залежить від міри співпадіння інтересів забудовників і споживачів на ринку нерухомості. 
Основна суперечність між ними виникає тоді, коли забудовники прагнуть збільшити обсяги введення нового житла, середні площі квартир, намагаючись максимізувати прибутки. Це викликає не лише серйозні проблеми з їхньою реалізацією, оскільки не враховано потреби споживачів та кон'юнктура цього сегменту ринку, але й незбалансованість розвитку ринку нерухомості в частині попиту і пропозиції. Не всі домогосподарства потребують великих квартир чи будинків, значним попитом на вторинному ринку користуються квартири невеликої житлової площі. Однак в останні роки в Україні збільшується середня житлова і загальна площа нових квартир (рис. 1). Середня житлова площа квартир, збудованих пізніше 2001 року, зросла на

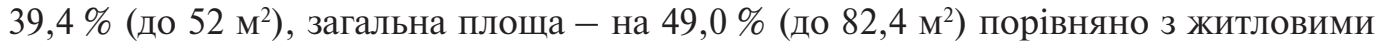
об’єктами, збудованими у 1940-х роках. Співвідношення загальної та житлової площі також зросло за цей період із 1,48 до 1,58 рази. Така ситуація лише знижує доступність житла чи відтерміновує його придбання на невизначений час.

Розвиток житлового будівництва в країні та оновлення житлового фонду в контексті завдань поліпшення житлових умов населення характеризує динаміка новозбудованих квартир у розрахунку на постійне населення країни, що має хвилеподібний вигляд починаючи з 1970 року (рис. 2). Так, у 2017 р. кількість таких квартир у розрахунку на 1000 осіб постійного населення становила три квартири, зросла порівняно з 2016 р. на 15,3 \% (проти 2000 р. збільшення становило 2,3 рази, однак проти 1990 р. спостерігається зменшення в 1,86 рази). Зростання обсягів введення в експлуатацію нового житла зазвичай співпадає з періодами економічного пожвавлення чи зростання, поліпшенням інвестиційного клімату та платоспроможності потенційних покупців житлової нерухомості. На відміну від інших сфер економічної діяльності, будівництво доволі швидко реагує на кон’юнктуру ринку, економічні цикли та загальну соціальну ситуацію в країні.

Проте конструктивні та технологічні особливості будівництва, його основні екологічні параметри, що найбільше впливають на умови життя населення, змінюються не так динамічно, оскільки більшою мірою залежать від темпів оновлення техніко-технологічної бази, iіi інноваційності та можливостей комерціалізації досягнень у цій сфері. За 2000-2013 рр. сформовано тенденцію до поширення у житловому будівництві змішаних будівельних матеріалів за високої частки цегляних будівель як найсприятливіших для збереження здоров'я населення (рис. 3).

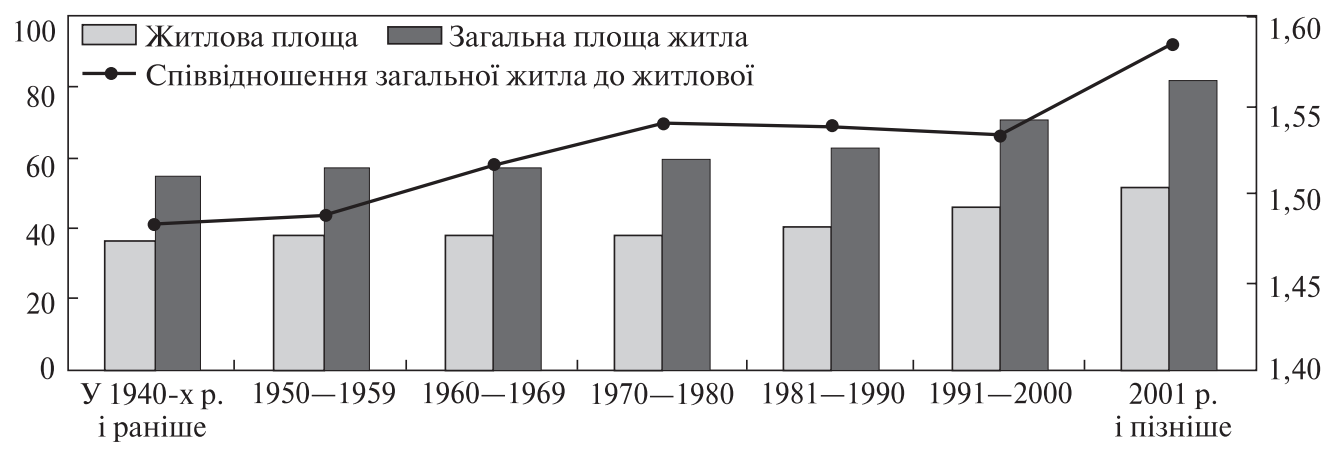

Рис. 1. Розмір середньої площі житла домогосподарства залежно від періоду будівництва, $\mathrm{M}^{2}$

Джерело: побудовано за даними обстежень умов життя домогосподарств Державної служби статистики України. 


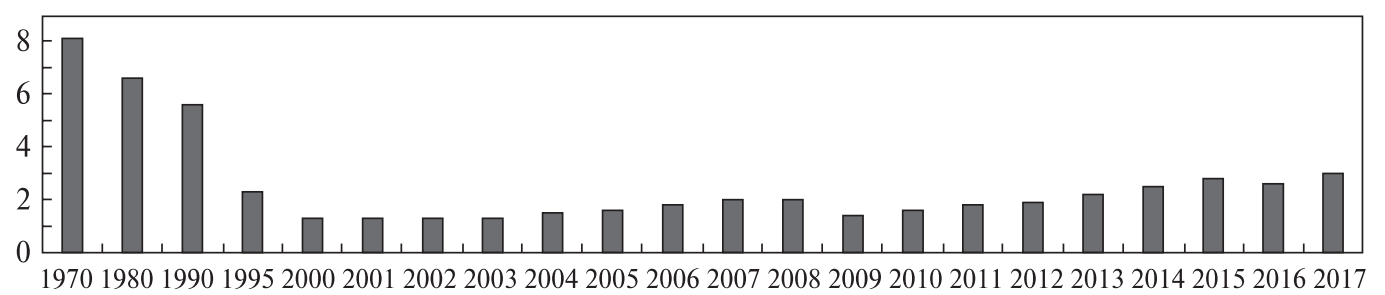

Рис. 2. Кількість збудованих квартир на 1000 населення, 1970-2017 pp., шт.

Джерело: [7, 8].

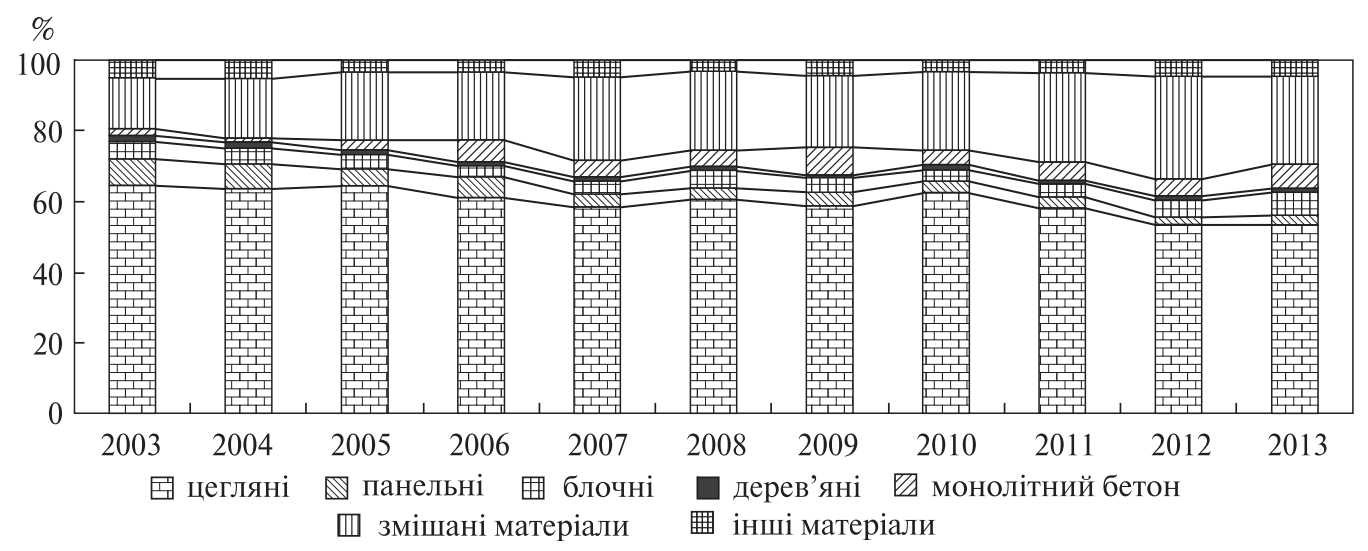

Рис. 3. Розподіл загальної площі введених в експлуатацію нових житлових будинків за матеріалами стін, 2003-2013 рр., \% до загального обсягу

Джерело: $[9,10]$.

Переорієнтація забудовників на потреби споживачів в Україні відбувається повільними темпами, необхідність їх прискорення засвідчує значний сегмент не реалізованих квартир на первинному ринку нерухомості. Зміни у структурі новозбудованих житлових квартир за кількістю кімнат як відповідній реакції забудовників на потреби споживачів демонструють пріоритетність новобудов невеликої житлової площі. 3 уведених в експлуатацію у 2017 році 22,9 тис. нових житлових будинків 58,1 \% загальної площі припадало на квартири з двома і більше кімнатами, переважали однокімнатні - 32,2 \% та двокімнатні - 27,0 \%; на п’ятикімнатні квартири і більше припадало лише 12,1\%. Протягом 2003-2013 рр. найбільше зросла частка однокімнатних квартир - на 21 в. П., скоротилась частка трикімнатних - на 24,3 в. п.; частка двокімнатних квартир у структурі новобудов залишилась майже без змін (рис. 4).

Не менш важливе значення для житлових умов населення має поверховість будівель. Доцільність житлової забудови певної поверховості з огляду на якість умов проживання населення $є$ дискусійним питанням - з цього приводу існують різні експертні висновки, нерідко протилежного характеру. Згідно з ДБН В.1.1-7:2016 «Пожежна безпека об’єктів будівництва», за умовною висотою будинки класифікують: малоповерхові - висотою до 9 м (до 3-х поверхів); багатоповерхові - від 3 до 9 поверхів $(9<\mathrm{H} \leq 26,5 \mathrm{M})$; підвищеної поверховості - від 9 до 16 поверхів $(26,5<\mathrm{H}$ $\leq 47 \mathrm{M})$; висотні - понад 16 поверхів $(\mathrm{H}>47 \mathrm{M})$ [11]. 


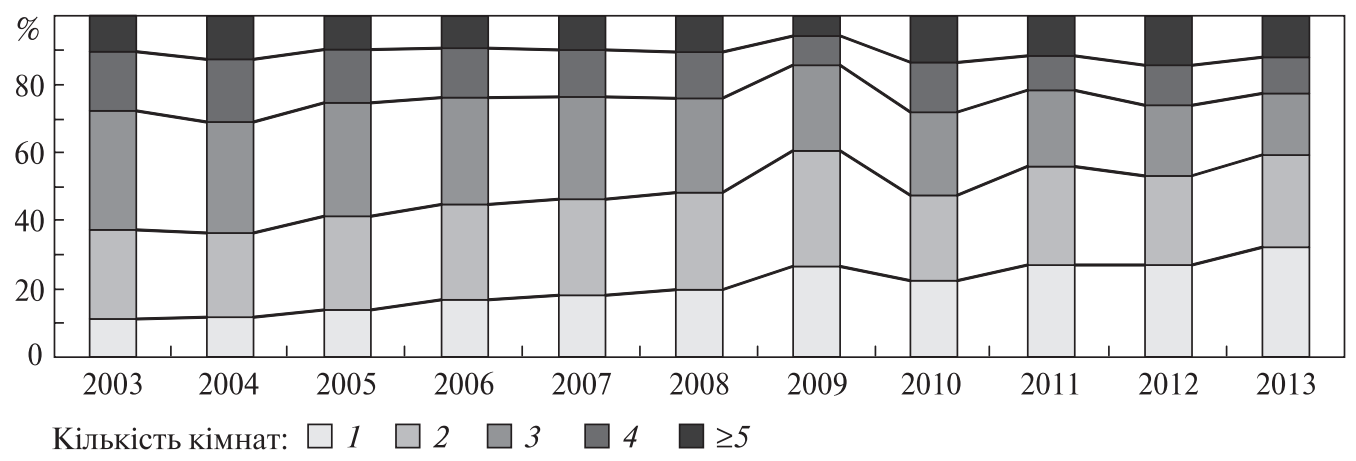

Рис. 4. Розподіл збудованих квартир за кількістю кімнат, 2003-2013 рр., \%

Джерело: $[9,10]$.

Зокрема, за рекомендаціями $\mathrm{CC}$ не доцільно зводити житлові будинки вище за сьомий поверх, оскільки їх визначено як некомфортні і такі, що знижують потенціал здоров'я та якість життя людей. За дослідженнями соціологів, через постійне проживання у висотних будинках у людей нерідко починаються проблеми з психікою, а діти відстають у фізичному і розумовому розвитку [12]. Більшість населення в Японії, США, Нідерландах проживає в житлових будинках з одним чи двома поверхами. Зокрема, у Великій Британії вище третього поверху проживає не більше $3 \%$ населення. Значного поширення в європейських країнах набули так звані блокові забудови, які складаються із 8-10 одно- або двоповерхових будинків, на території яких передбачено паркінги та озеленену територію. Не менш популярними є квартири на першому поверсі з відгородженими терасами у Німеччині, Австрії, Великій Британії, Нідерландах. У країнах Балтії користуються попитом таунхауси як перехідний тип житла між одно- і багатоквартирним будинком з власним приватним простором площею $20-40 \mathrm{M}^{2}[13]$.

В Україні, на відміну від більшості європейських країн, набуває широкого поширення і популярності багатоповерхова забудова житлових приміщень 3 певними економічними і соціальними перевагами і недоліками. Насамперед, вона потребує меншої площі порівняно з аналогічними одноповерховими будівлями, створює умови для тісної комунікації, оснащення новітніми технічними засобами. Це забезпечує оптимальний режим експлуатації, інженерно-технічні новації, скорочення загальних видатків на утримання. Привабливість такого житла зростає за умов оснащення підземним паркінгом чи пішохідної доступності до транспортних магістралей, а також територіальної близькості до об'єктів побутового сервісу чи соціально-культурних закладів. Недоліками такого типу забудови є значно гірші умови повітрообміну, вищий рівень забруднення мікроорганізмами, підвищений рівень шуму, вібрації та електромагнітного випромінювання, що негативно позначається на здоров'ї їхніх мешканців. Розподіл загальної площі введених в експлуатацію нових житлових будинків протягом 2005-2017 років демонструє тенденцію до зростання частки багатоповерхових будинків (рис. 5). Отже, домінують економічні переваги, які дають змогу забудовникам швидше і з меншими витратами завершувати нове будівництво, досягаючи максимізації прибутків. При цьому вагома частка внутрішніх будівельних робіт перекладається на майбутніх мешканців. Така практика стала нормою в новобудовах країни. 


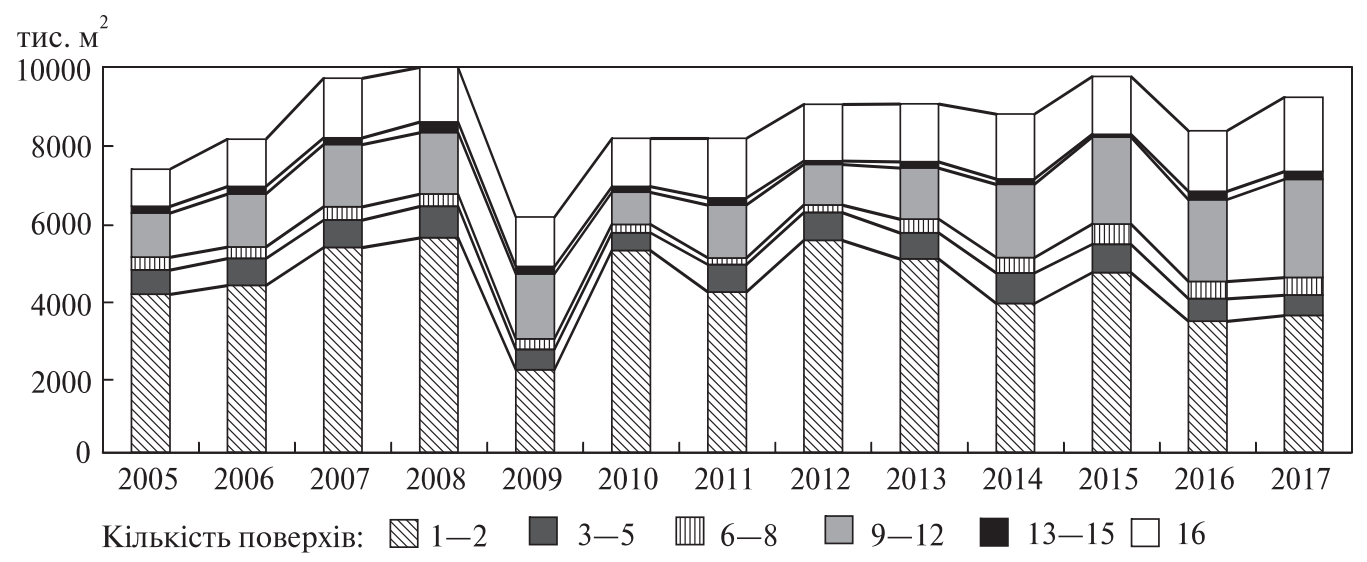

Рис. 5. Розподіл загальної площі прийнятих в експлуатацію нових житлових будівель за поверховістю, тис. м $^{2}$

Джерело: [9, 10, 14].

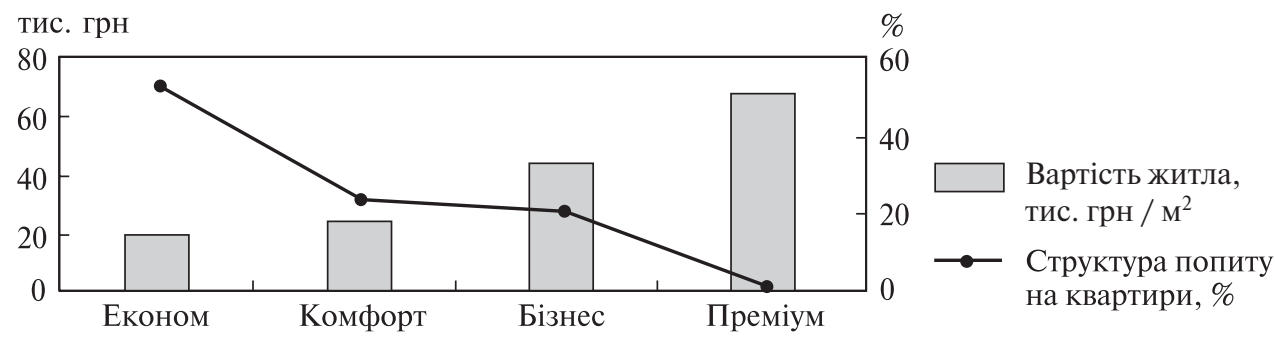

Рис. 6. Вартість та структура попиту на житло за класами у Києві, 2017 р.

Джерело: [15].

Активність впливу будівництва на житлові умови населення є вищою у Києві як діловому центрі країни, а також у Київській області, містах Одесі та Львові. У Києві як потужному інвестиційному центрі та центрі тяжіння висококваліфікованих кадрів відчутним є зростання інвестиційного інтересу до престижного житла, зокрема у нових житлових комплексах бізнес- і преміум-класу. Зокрема, у 2017 р. попит на житло бізнес-класу зріс до рівня $21 \%$ у загальній структурі попиту на первинному ринку нерухомості; попит на квартири преміум-класу протягом року збільшився до $2 \%[15]$.

За експертними оцінками, у 2017 році у Києві у сегменті первинної нерухомості пріоритет належав квартирам у сегменті економ-класу. Попит на них зберігався на рівні $53 \%$ (за середньої ціни 19 тис. грн / м²), при цьому реальна потреба у квартирах комфорт-класу знизилась до $24 \%$. Такі зміни обумовлені тим, що інвестори почали ретельніше підходити до вибору класу житлових примішень, зважаючи на те, що за аналогічних характеристик ціни в комплексах комфорт-класу на 30 \% вищі, ніж у комплексах економ-класу (рис. 6).

В умовах обмеженості фінансових ресурсів та низької купівельної спроможності більшості населення саме цінові характеристики обумовлюють вибір інвесторами того чи іншого типу житлової забудови. У січні 2017 року середня вартість квартир 
тис. грн

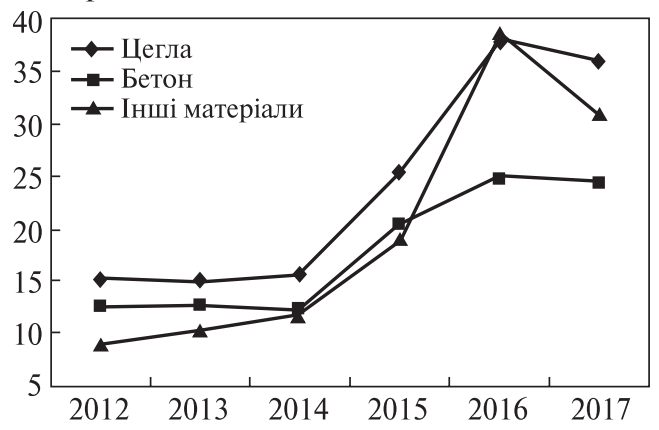

тис. $\$$

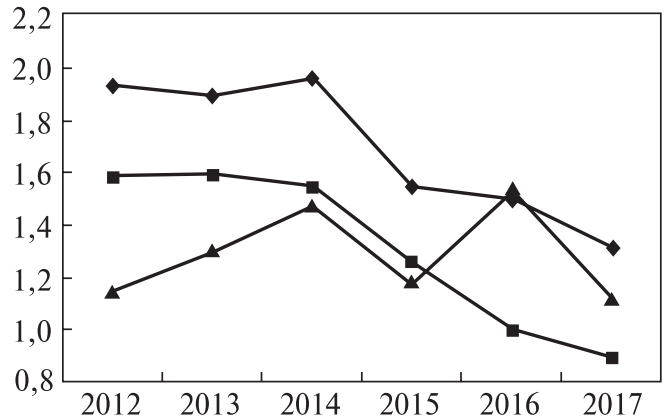

Рис. 7. Вартість житла за матеріалами стін у Києві у гривнях та доларах США за 1 м² (січень 2012 - 2017 pp.)

Джерело: [16].

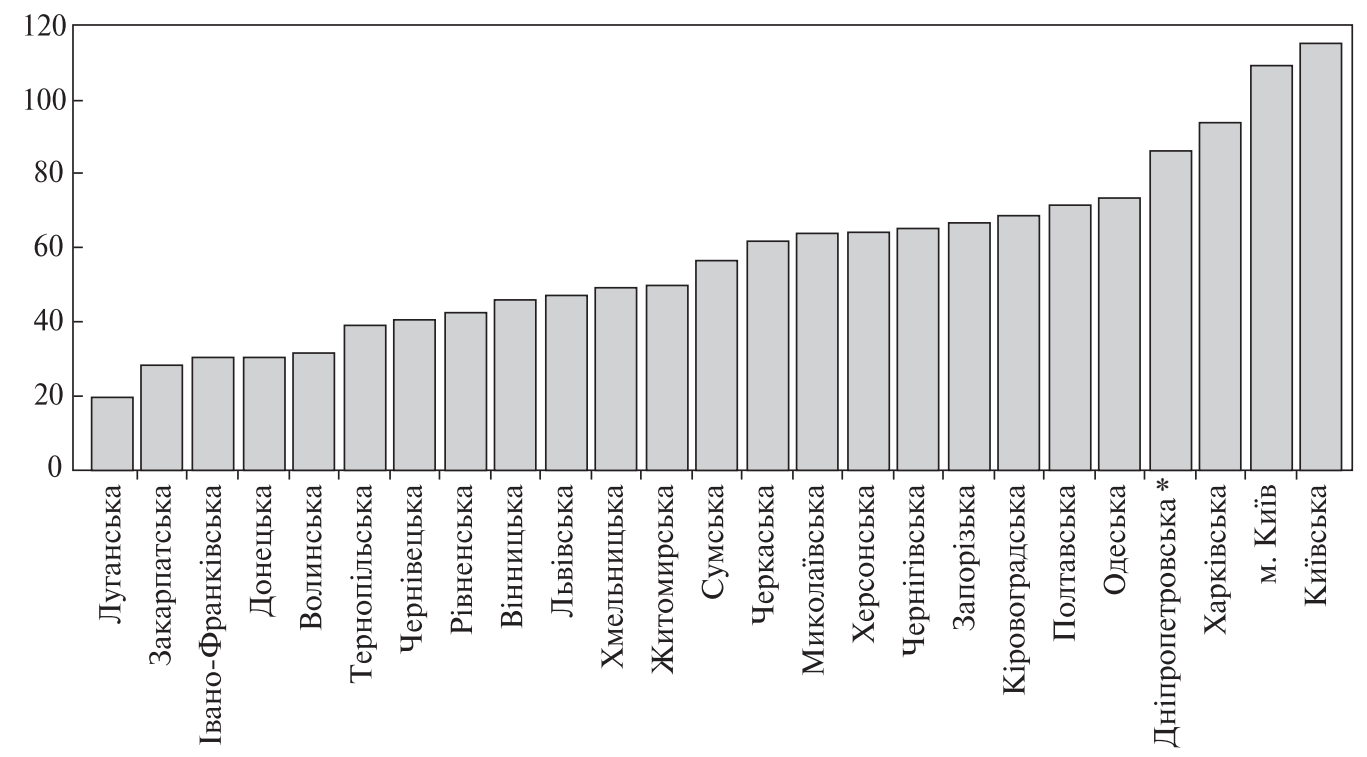

Рис. 8. Кількість угод купівлі-продажу квартир і житлових будинків у регіонах України на 10000 постійного населення в 2017 році

Джерело: [16].

Примітка: * Дпіропетровська область нині Січеславська.

у новобудовах Києва становила 29400 грн / м², подвоївшись порівняно з аналогічним періодом 2012 року. Протягом 2012-2017 рр. зростання вартості житла становило (в гривневому еквіваленті): для цегляних будівель (2,3 раза), бетонних (1,9 раза), будівель з інших матеріалів (3,4 раза) та відповідно спостерігалось зменшення в доларах США - в 0,7; 0,6; 0,9 раза (рис. 7).

Активність учасників первинного і вторинного сегментів ринку нерухомості $€$ різною за регіонами - найбільшу кількість угод з купівлі та продажу об'єктів нерухомого майна на 10000 постійного населення у 2017 році було укладено в Київській області - 114 та Києві - 108, найменше - у Луганській області - 19 (рис. 8). 
Перспективним напрямом розвитку сучасного будівництва як основи формування якісних житлових умов більшості населення країни є енергоефективність, оскільки у житлових будинках витрачається близько 70 \% теплової енергії та 80 \% питної води від їх споживчого обсягу. Енергоефективність вирішує такі основні завдання: оптимізує вартість утримання житла завдяки раціональному використанню енергоресурсів, знижує рівень енергозалежності, сприяє утвердженню альтернативних джерел енергії, а головне - формує комфортні умови проживання. Через низькі теплоощадні характеристики будинків так званої масової забудови (майже третина житлового фонду) виникають втрати близько 40 \% теплової енергії, у мережах теплопостачання - до 25 \%, що значно перевищує аналогічні показники більшості країн світу [17]. Найбільші втрати природного газу експерти пов'язують із втратами теплової енергії у споживача - до 30 \%, під час передання теплової енергії - 25 \%, у процесах виробництва на котельні - до $22 \%$. За результатами обстежень тепловтрати у будинках масової забудови становили: вікна - $16 \%$, стіни - $42 \%$, дах - 7 \%, підвал - 5 \%, повітрообмін - 30 \%. Витрати палива на вироблення 1 Гкал тепла в комунальній теплоенергетиці країни становлять 160-180 кг у. п., у розвинутих країнах вони значно менші і знаходяться на рівні 145-150 кг [18]. На жаль, в Україні значна частка теплоенергетики комунальної власності (котельне обладнання і теплові мережі) вичерпала нормативний термін експлуатації.

Важливо зазначити, що у роки від здобуття незалежності в Україні неодноразово оновлювали норми теплового захисту житлових будинків. Зокрема, у 1993 році (зміни у СНиП ІІ-3-79) та у 2007 році з уведенням нових ДБН В.2.6-31:2006 «Конструкції будинків і споруд. Теплова ізоляція будівель», а також у 2017 році з ухваленням ДБН В.2.6-31:2016 [19]. Останні відповідають європейським вимогам, проте залишаються найнижчими серед цих країн. Зокрема, за новими стандартами в теплоізольованому будинку припустимі втрати тепла крізь вікна на 12 \%, крізь стіни - на 24 \% нижчі порівняно з житловими будинками, введеними в експлуатацію до 1994 року. В країнах Західної Європи чинні норми щорічних витрат енергії у житловому фонді становлять близько 150-260 кВт • год/м²; країнах Скандинавії - 120-150 кВт • год/м² (6080 кВт ·од/м² - для енергоефективних будинків). Для країн Східної Свропи, і в Україні, аналогічні показники становлять близько 250-400 кВт • год/м ${ }^{2}$ [17]. Таким чином, низький рівень енергоефективності закладається ще на етапі житлового будівництва і потребує відповідних заходів, спрямованих на їхнє істотне скорочення.

У будь-якій європейській країні досягнутий рівень житлової енергоефективності залежить від результативності стандартизації цієї сфери. Розвинену й ефективну систему чинних стандартів і норм енергоефективного житлового будівництва створено у США, Швеції, Данії, Ірландії. Документами стратегічного значення передбачено широке використання альтернативних джерел енергії. Зокрема, Енергетичною стратегією Євросоюзу закріплено таке завдання як скорочення рівня споживання енергоносіїв на 20 \% до 2020 р. на основі диверсифікації джерел енергії на користь альтернативних. Директивою Свропейського парламенту (№ 2010/31/СС) визначено першочергові завдання, які зобов’язують забудовників під час модернізації житлового фонду істотно зменшувати енерговитрати (до 50 \%) [20].

Для цілей стандартизації та регламентації різних аспектів енергозбереження у виробничій та житловій сферах в Україні сформовано відповідну нормативно-правову базу, представлену Законом України «Про енергозбереження» від 01.07.1994 № 75/94-ВР з відповідними змінами і доповненнями, Законом України «Про енергетичну ефективність будівель» від 22.06.2017 № 2118-VIII, а також системою чинних 
державних стандартів та будівельних норм. Головні базові принципи енергоефективності у новому будівництві та модернізації житлового фонду почали реалізовувати 3 набуттям чинності ДБН В.2.6-31-2006 «Теплова ізоляція будівель» у 2007 році та їхнім підкріпленням ДСТУ Б А.2.2-8:2010 відповідним розділом «Енергоефективність» у проектах будівельної документації.

3 грудня 2018 року в Україні набули чинності ДБН В.2.6-33:2018 «Конструкції зовнішніх стін з фасадною теплоізоляцією. Вимоги до проектування», які увідповіднено з європейськими вимогами та поширено на проектування зовнішніх стін із фасадною теплоізоляцією житлових споруд під час нового будівництва чи капітального ремонту. За експертними оцінками, їх уведення може забезпечити щорічну економію до $15 \%$ теплової енергії та близько 3 млрд грн за умови модернізації щонайменше $3 \%$ всіх будівель [16]. Отже, є підстави вважати, що з часом проблема енергоефективності житлового фонду країни буде вирішена і населення матиме змогу мешкати в комфортних житлових умовах. Цьому сприятимуть також державні програми з енергоефективності житлових приміщень для населення, які передбачають кредитування і часткову компенсацію витрат на утеплення, установлення приладів обліку тепла, ремонт систем теплопостачання, підготовку енергопаспортів для окремих житлових споруд.

Висновки. У будь-якій країні світу житлове будівництво є важливою сферою економічної діяльності та матеріальною основою формування житлових умов населення, від розвитку якої залежать не лише основні якісні параметри житлових споруд, рівень їхнього технічного оснащення та загальна комфортність, але й значною мірою потенціал здоров'я населення. Тривалий процес реформування та розвитку будівництва проходили усі європейські країни, використовуючи нові технології інвестування й стимулювання розвитку цієї сфери, об’єднуючи державну підтримку, механізм іпотечного кредитування та контрактні заощадження.

В Україні вплив розвитку будівництва на житлові умови населення має суперечливий характер, зокрема спостерігається неспівпадіння інтересів забудовників, інвесторів і майбутніх мешканців у частині поверховості будинків, загальної та житлової площі квартир, їхнього внутрішнього облаштування. Не виправданими є намагання забудовників мінімізувати власні витрати.

Очевидно, що в Україні недостатньо стимулювати розвиток будівництва на державному рівні, важливо створити умови для розвитку конкурентного середовища, запровадити дієві фінансово-кредитні механізми, спроможні забезпечити умови для купівлі житла широкими верствами населення. Вони мають спиратись на довіру до банківського сектору економіки та стимулювати розвиток фонду орендного житла, доступного для населення з низьким рівнем доходів.

Подальший напрям досліджень має бути пов'язаний із визначенням нових механізмів формування сприятливих житлових умов населення та ефективного розвитку ринку житлової нерухомості у взаємозв’язку з процесами гармонізації інтересів усіх суб’єктів.

\section{ЛІТЕРАТУРА}

1. Брунко П. Фінансування енергоефективного будівництва // СХІД. Економічні науки. 2016. - № 1 (141). - С. 5-13.

2. Черенько Л.М. Житлові умови населення України та вибір пріоритетних напрямів житлової політики // Демографія та соціальна економіка. - 2018. - № 1 (32). - C.126-139. - https://doi. org/10.15407/dse2018.02.126 
3. Реут А.Г. Еволюція житлових умов під впливом соціальних змін // Демографія та соціальна економіка. - 2017. - № 3 (31). - C. 174-185. - https://doi.org/10.15407/dse2017.03.174

4. Марченко М.С. Щодо питання імплементації європейських норм забезпечення соціальним житлом у праві України // Збірник наук. праць ХНПУ імені Г.С. Сковороди «Право».Вип. 27. - 2017. - С. 107-111.

5. Про затвердження Єдиного класифікатора житлових будинків залежно від якості житла та наявного інженерного обладнання [Електронний ресурс]. - Режим доступу: http://www.uazakon. com/document/spart66/inx66774.htm (дата звернення: 28.03.2019).

6. Плюси та мінуси сучасних технологій будівництва [Електронний ресурс]. - Режим доступу: http://stroyobzor.ua/news/89660.html (дата звернення: 28.03.2019).

7. Капитальное строительство СССР: стат. Сб. [Електронний ресурс]. - Режим доступу: http:// istmat.info/node/25784 (дата звернення: 28.03.2019).

8. Прийняття в експлуатацію загальної площі житла та кількість збудованих квартир [Електронний ресурс]. - Режим доступу: http://www.ukrstat.gov.ua/ (дата звернення: 28.03.2019).

9. Житлове будівництво в Україні у 2000-2009 роках.: Стат. Сб. / Державна служба статистики України. - Київ, $-2010 .-91$ с.

10. Житлове будівництво в Україні у 2010-2015 роках: Стат. Сб. / - Державна служба статистики України. - Київ, $-2016 .-72$ с.

11. ДБН В.1.1-7:2016 «Пожежна безпека об’єктів будівництва» [Електронний ресурс]. - Режим доступу: http://dbn.co.ua/load/normativy/dbn/1-1-0-88 (дата звернення: 28.03.2019).

12. Gifford R. The Consequences of Living in High-Rise Buildings Architectural Science Review, - 2007. Vol. 50.1. - 16 p. - https://doi.org/10.3763/asre.2007.5002

13. Гнесь І.П. Вплив поверховості житла на здоров'я мешканців / Національний університет «Львівська політехніка». - Львів, 2013. - С. 67-79.

14. Житлове будівництво в Україні у 2012-2017 роках: Стат. Сб. / Державна служба статистики України. - Київ, 2018. - 64 с.

15. Итоги 2017 года: рынок жилой недвижимости Киева [Електронний ресурс]. - Режим доступу до ресурсу: http://abcnews.com.ua/ru/analytics/itogi-2017-goda-rynok-zhiloi-nedvizhimosti-kieva (дата звернення: 28.03.2019).

16. Інформаційно-аналітичний портал нерухомості [Електронний ресурс]. - Режим доступу: domik. uа (дата звернення: 28.03.2019).

17. Волков В.П. Проблеми енергозбереження у житловому фонді [Електронний ресурс]. - Режим доступу: http://www.irbis-nbuv.gov.ua/cgi-bin/irbis_nbuv/cgiirbis_64.exe?C21COM=2\&I21DBN=UJRN\&P21DBN=UJRN\&IMAGE_FILE_DOWNLOAD=1\&Image_file_name $=$ PDF/ecvu_2013_ 20(1)_18.pdf (дата звернення: 28.03.2019).

18. Галузева програма енергоефективності та енергозбереження у житлово-комунальному господарстві на 2010-2014 роки: наказ Міністерства з питань житлово-комунального господарства від 10.11.2009 № 352 [Електронний ресурс]. - Режим доступу: http://normativ.com.ua/types/ tdoc17772.php (дата звернення: 28.03.2019).

19. ДБН В.2.6-31:2016 «Теплова ізоляція будівель» [Електронний ресурс]. - Режим доступу: http:// www.minregion.gov.ua/wp-content/uploads/2016/01/DBN-V.2.6-31-2016-Teplova-izolyatsiya-budivel. pdf (дата звернення: 28.03.2019).

20. Директива 2010/31/ЄС Європейського парламенту і Ради від 19 травня 2010 року щодо енергетичної ефективності будівель [Електронний ресурс]. - Режим доступу: http://saee.gov.ua/documents/dyrektyva_2010_31.doc (дата звернення: 28.03.2019).

\section{REFERENCES}

1. Brunko, P. (2016). Finansuvannia enerhoefektyvnoho budivnytstva [Financing for energy-efficient construction]. Ekonomichni nauky - Economic sciences, 1(141), 5-13 [in Ukrainian].

2. Cherenko, L.M. (2018). Zhytlovi umovy naselennia Ukrainy ta vybir priorytetnykh napriamiv zhytlovoi polityky [Housing conditions of the population of Ukraine and the choice of priority areas of housing policy]. Demohrafiia ta sotsialna ekonomika - Demography and social economy, 1(32), 126-139. https://doi.org/10.15407/dse2018.02.126 [in Ukrainian]. 
3. Reut, A.G. (2017). Evoliutsiia zhytlovykh umov pid vplyvom sotsialnykh zmin [Evolution of housing conditions under the influence of social change]. Demohrafiia ta sotsialna ekonomika - Demography and social economy, 3(31), 174-185. - https://doi.org/10.15407/dse2017.03.174 [in Ukrainian].

4. Marchenko, M.S. (2017). Shchodo pytannia implementatsii yevropeiskykh norm zabezpechennia sotsialnym zhytlom u pravi Ukrainy [On the Issue of Implementation of European Norms for Provision of Social Housing in the Law of Ukraine]. Zbirnyk nauk prats KhNPU imeni H.S. Skovorody «Pravo» - Collection of Sciences works of KNPU named G.S. Skovorody, 27, 107-111 [in Ukrainian].

5. Pro zatverdzhennia Yedynoho klasyfikatora zhytlovykh budynkiv zalezhno vid yakosti zhytla ta naiavnoho inzhenernoho obladnannia [On the approval of the Single Classifier of residential buildings, depending on the quality of housing and existing engineering equipment].(n.d.). Retrieved from http://www.uazakon. com/document/spart66/inx66774.htm [in Ukrainian].

6. Pliusy ta minusy suchasnykh tekhnolohii budivnytstva [Pros and cons of modern construction technologies]. (n.d.). Retrieved from http://stroyobzor.ua/news/89660.html [in Ukrainian].

7. Kapytalnoe stroytelstvo SSSR: stat. sbornyk [Capital construction of the USSR: stat. compilation]. (n.d.). Retrieved from http://istmat.info/node/25784 [in Russian].

8. Pryiniattia v ekspluatatsiiu zahalnoi ploshchi zhytla ta kilkist zbudovanykh kvartyr [Acceptance of the total living space and the number of built apartments]. (n.d.). Retrieved from http://www.ukrstat.gov.ua/ [in Ukrainian].

9. Zhytlove budivnytstvo v Ukraini u 2000-2009 rokakh [Housing construction in Ukraine in 2000-2009]. (2010). State Statistics Service of Ukraine. Kyiv [in Ukrainian].

10. Zhytlove budivnytstvo v Ukraini u 2010-2015 rokakh [Housing construction in Ukraine in 2010-2015]. (2016). State Statistics Service of Ukraine. Kyiv [in Ukrainian].

11. DBN V.1.1-7:2016 «Pozhezhna bezpeka obiektiv budivnytstva» [DBN V.1.1-7: 2016 Fire safety of construction projects]. (2016). Retrieved from http://dbn.co.ua/load/normativy/dbn/1-1-0-88 [in Ukrainian].

12. Gifford Robert (2007). The Consequences of Living in High-Rise Buildings. Architectural Science Review, Vol. 50, 1. Retried from https://doi.org/10.3763/asre.2007.5002

13. Hnes, I.P. (2013). Vplyv poverkhovosti zhytla na zdorovia meshkantsiv [Influence of the surface of housing on the health of residents]. Natsionalnyi universytet «Lvivska politekhnika» [in Ukrainian].

14. Zhytlove budivnytstvo v Ukraini u 2012-2017 rokakh [Housing construction in Ukraine in 2012-2017]. (2018). State Statistics Service of Ukraine. Kyiv [in Ukrainian].

15. Ytohy 2017 hoda: runok zhyloy nedvyzhymosty Kyeva [Results of 2017: Kiev residential real estate market]. (n.d.). Retrieved from http://abcnews.com.ua/ru/analytics/itogi-2017-goda-rynok-zhiloi-nedvizhimosti-kieva [in Russian].

16. Informatsiino-analitychnyi portal nerukhomosti [Information and analytical portal of real estate]. (n.d.). Retrieved from http://domik.ua [in Ukrainian].

17. Volkov, V.P. (n.d.). Problemy enerhozberezhennia u zhytlovomu fondi [Problems of energy saving in a housing stock]. Retrieved from http://www.irbis-nbuv.gov.ua/cgi-bin/irbis_nbuv/cgiirbis_64.exe?C21COM=2$\& I 21 D B N=U J R N \& P 21 D B N=U J R N \& I M A G E \_F I L E \_D O W N L O A D=1 \& I m a g e$ file_name=PDF/ ecvu_2013_20(1)_18.pdf [in Ukrainian].

18. Haluzeva prohrama enerhoefektyvnosti ta enerhozberezhennia u zhytlovo-komunalnomu hospodarstvi na 2010-2014 roky [Sectoral program of energy efficiency and energy saving in housing and communal services for 2010-2014]. (n.d.). Retrieved from http://normativ.com.ua/types/tdoc17772.php [in Ukrainian].

19. DBN V.2.6-31:2016 «Teplova izoliatsiia budivel» [DBN V.2.6-31: 2016 «Thermal insulation of buildings»]. (2016). Retrieved from http://www.minregion.gov.ua/wp-content/uploads/2016/01/DBN-V.2.6-312016-Teplova-izolyatsiya-budivel.pdf [in Ukrainian].

20. Dyrektyva 2010/31/YeS Yevropeiskoho parlamentu i Rady shchodo enerhetychnoi efektyvnosti budivel [Directive 2010/31/EU of the European Parliament and Council on the energy performance of buildings]. (2010). Retrieved from http://saee.gov.ua/documents/dyrektyva_2010_31.doc [in Ukrainian].

Стаття надійшла до редакції журналу 02.05.2019. 


\section{ПРОФЕСІЙНА ОСВІТА, ПРАЦЯ ТА ЗАЙНЯТІСТЬ}

https://doi.org/10.15407/dse2019.02.152

УДК $377 / 378$ (477)

JEL CLASSIFICATION: I21, I28

\section{B.M. HOBIKOB}

д-р екон. наук, проф., голов. наук. співроб.

Інститут демографії та соціальних досліджень

ім. М.В. Птухи НАН України

01032, Україна, м. Київ, бул. Т. Шевченка, 60

E-mail: valery.economy@ukr.net

ORCID 0000-0001-5892-815X

\section{ПРАКТИКО-ОРІЕНТОВАНА МОДЕЛЬ ПРОФЕСІЙНОЇ ОСВІТИ}

Вумовах трансформації економіки України дефіцит кваліфікованих кадрів стає однією з головних перешкод розвитку промисловості, аграрного виробництва, будівельної галузі, соціальної інфраструктури. Передумовою економічного зростання є збереження і розвиток професійно-технічної освіти. Проблема потребує системного підходу до вирішення питань підготовки кваліфікованих працівників, у межках якого координуються законодавчі, нормативні, організаційно-управлінські, фінансові та програмнопедагогічні заходи. В Україні рішення про впровадження практико-орієнтованої (дуальної) освіти ухвалено 2018 року. За основу взято досвід навчання у Німеччині. Для напрацювання досвіду функціонування нової моделі професійної освіти необхідний певний час, проте само по собі визнання і копіювання міжнародної практики не вирішує економічних і соціальних питань підготовки кваліфікованих кадрів. Дуальна модель передбачає залучення до системи професійної освіти роботодавців як провайдерів освітніх послуг. В Україні, як і у багатьох країнах світу, упровадження дуальної моделі в такому форматі є проблематичним. Відсутня достатня нормативна база та інституціональні механізми для зацікавленості роботодавців у розвитку дуальної форми навчання як прогресивної форми здобуття освіти, що відрізняється від інших форм, застосованих у рамках практико-орієнтованої професійної освіти. Уроботі дуальну освіту розглянуто як інфраструктурну державно-регіональну модель, яка забезпечує взаємодію ряду процесів: кадровий прогноз, професійну орієнтацію молоді, розробку кваліфікаційних стандартів, планування і організацію освітнього процесу і оцінку рівня освіти випускників навчальних закладів. Викладено відповідні пропозиції щодо розвитку дуальної моделі освіти.

Ключові слова: професійно-технічна освіта, практико-орієнтована модель, дуальне навчання, професійні стандарти, кластер.

\section{В.Н. Новиков}

Д-р экон. наук, проф., глав. науч. сотр.

Институт демографии и социальных исследований

им. М.В. Птухи НАН Украины

01032, Украина, г. Киев, бул. Т. Шевченко, 60

E-mail: valery.economy@ukr.net

ORCID 0000-0001-5892-815X

(C) НОВІКОВ B.M., 2019 


\title{
ПРАКТИКО-ОРИЕНТИРОВАННАЯ МОДЕЛЬ ПРОФЕССИОНАЛЬНОГО ОБРАЗОВАНИЯ
}

В условиях трансформационной экономики Украины дефицит квалифицированных кадров становится одним из главных препятствий развития промышленности, аграрного производства, строительной отрасли, социальной инфраструктуры. Предварительным условием экономического роста является сохранение и развитие профессионально-технического образования. Проблема требует системного подхода к решению вопросов подготовки квалифицированных работников, в рамках которого координируются законодательные, нормативные, организационно-управленческие, финансовые и программнопедагогические мероприятия. В Украине решение о внедрении дуального образования принято в 2018 году. За основу взята практика обучения в Германии. Для наработки опыта функиионирования новой модели профессионального образования необходимо время, однако само по себе признание и копирование международного опыта не решает экономических и социальных вопросов подготовки квалифицированных кадров. Дуальная модель предполагает привлечение в систему профессионального образования работодателей как провайдеров образовательных услуг. В Украине, как и во многих странах мира, внедрение дуальной модели в таком формате проблематично. Отсутствует достаточная нормативная база и институциональные механизмы для заинтересованности работодателей в развитии дуальной формы обучения как прогрессивной формы получения образования, отличающейся от других форм, используемых в рамках практико-ориентированного профессионального образования. В работе дуальное образование рассмотрено как инфраструктурная государственно-региональная модель, обеспечивающая взаимодействие ряда процессов: кадровый прогноз, профессиональную ориентацию молодежи, разработку квалификационных стандартов, планирование и организацию образовательного процесса и оценку уровня образования выпускников учебных заведений. Изложены предложения по развитию дуальной модели образования.

Ключевые слова: профессионально-техническое образование, практико-ориентированная модель, дуальное обучение, профессиональные стандарты, кластер.

\author{
V.M. Novikov \\ Dr. Sc. (Economist), Prof., Head of Department \\ Ptoukha Institute for Demography \\ and Social Studies of the National Academy of Ukraine \\ 01032, Ukraine, Kyiv, Taras Shevchenko Blvd., 60 \\ E-mail: valery.economy@ukr.net \\ ORCID 0000-0001-5892-815X
}

\section{PRACTICE-ORIENTED MODEL OF PROFESSIONAL EDUCATION}

In the conditions of transformations of the Ukrainian economy, the shortage of skilled personnel is becoming one of the main obstacles in development of industry, agricultural production, construction, and social infrastructure. A prerequisite for economic growth is the preservation and development of vocational education. The problem requires a systematic approach to the solution of issues of training qualified workers, within whose framework the legislative, regulatory, organizational, managerial, financial, and program-pedagogical measures are coordinated. In Ukraine, the introduction of dual education was adopted in 2018 on the basis of experience in training of Germany. Gaining experience in the functioning of the new model of vocational education requires a certain period of time. However, the mere recognition and copying of international experience does not solve the economical and social issues of training qualified personnel. The dual model involves employers in the vocational education system as providers of educational services. In Ukraine, as in many countries of the world, the implementation of the dual model in such a format is problematic. There is a lack of a regulatory framework and institutional mechanisms to garner interest of employers in the development of the dual form education as a progressive form of education, which differs from others used in the framework of practice-oriented vocational education. In this paper, dual education is viewed as an infrastructure state-regional model that ensures the interaction of a number of processes: personnel forecast, vocational guidance of young people, development of qualification standards, planning and organization of the educational process and assessment of the level of education of graduates of educational institutions. Suggestions for the development of a dual model of education are given. Ways of modernizing the state system of training workers are proposed.

Keywords: vocational education, practice-oriented model, dual training, professional standards, cluster. 
Постановка проблеми, актуальність. 3 початку дев’яностих років минулого століття професійно-технічна освіта поступово втрачає свій імідж. А наслідки кризових явищ нульових років не можна подолати без структурних перетворень у сфері професійної підготовки кадрів. Серед основних проблем, які потребують термінового вирішення, нагальним є запровадження гнучкої системи управління галуззю, започаткування у рамках державно-приватного партнерства нових підходів до мотивування роботодавців з метою підготовки висококваліфікованих робітників. Сьогодні найвідоміший світовий бренд у професійній освіті - дуальне навчання, яке застосовує Німеччина та інші країни. Розробка основ та адаптація елементів дуальної освіти з урахуванням соціально-економічних особливостей України є актуальним завданням для науковців і практичних працівників.

Ступінь вивчення проблеми та аналіз публікацій. Проблематика дослідження процесів упровадження дуальної освіти в структуру системи підготовки кадрів в Україні поки не посіла відповідного до ії стратегічного значення місця у вітчизняних наукових розробках. Перевага у висвітлені питань розвитку дуальної освіти належить нині державним управлінцям і педагогічним працівникам системи професійних закладів. Позитивні наслідки дуальної форми навчання визначав М. Кучинський (М. Kuchinsky), підкреслюючи іiї важливу потенційну роль у здобутті профільної (професійної) середньої освіти, реалізації власних освітніх траєкторій та забезпечення мобільності молоді на ринку праці [1, с. 8]. А. Луцька (A. Lutska) звертає увагу, що для розвитку дуальної освіти немає достатньої нормативної бази і зацікавленості роботодавців у ії впроваджені [2, с. 9]. Сутність німецької моделі та перші кроки країни зі впровадження дуальної освіти наведено Т. Пятничук (Т. Pyatnychuk) [3, c. 27-31]. До невирішених питань дуального навчання К. Кудря і О. Сталінська (K. Kudrya and O. Stalinskaya) цілком слушно відносять створення інституціональних механізмів стимулювання 3 оцінки і застосування дуальної форми освіти на підприємствах [4]. Практику застосування дуальної освіти в Німеччині та в Україні у контексті професійних стандартів аналізував В. Новіков (V. Novikov) [5]. Заслуговують на увагу дослідження I. Каленюк (I. Kalenyuk), присвячені аналізу та застосуванню в Україні світового досвіду розвитку професійної освіти [6].

Мета. Визначити стан професійно-технічної освіти в Україні і на основі аналізу інституціональних особливостей дуальної форми навчання в Німеччині запропонувати шляхи модернізації державної освітньої системи у практико-орієнтованому напрямі підготовки кадрів.

Новизна. Обгрунтовано необхідні економічні умови і мотиваційні чинники забезпечення ефективності дуальної форми навчання і відродження професійної освіти в країні.

Методи дослідження. Використано графічний метод для огляду та аналізу статистичних даних, зокрема для порівняння звітних показників професійно-технічних закладів, характеристики складу сукупності професійних кадрів на ринку праці, визначення динаміки бюджетних витрат.

Викладення основного матеріалу. У XXI столітті стан економіки країн світу визначений якістю робочої сили. На відміну від XIX і XX століть, які були періодами технічної революції й освоєння фінансових та інформаційних ресурсів, нинішнє століття характеризується розвитком і реалізацією людського капіталу. Використання соціальних технологій в управлінні людським капіталом є першочерговою умовою соціально-економічного розвитку. 
Українські і зарубіжні дослідники одностайні у тому, що підвищення якості робочої сили стає головним пріоритетом у забезпеченні конкурентоздатності національної економіки. Збільшення інвестицій в освіту, удосконалення професійно освітнього рівня працівників набувають визначального значення для економічного розвитку. В Україні потенціал робочої сили професійно не відповідає запитам роботодавців і рівню міжнародних кваліфікаційних стандартів.

Посилення конкуренції на ринку праці висуває все вищі вимоги до працівників. Роботодавці намагаються залучити не тільки висококваліфіковану робочу силу, але й таку, яка за професійно-кваліфікаційним рівнем відповідає технологічним характеристикам виробництва. Поступово поняття якості робочої сили набуває значення «ускладненої категорії.

Між тим, чинна система підготовки кадрів характеризується високою інерційністю. Вона слабо реагує на зміни ринку праці під впливом нових технологій і не забезпечує адаптацію випускників професійно-технічних закладів до вимог роботодавців. Причина цього у відсутності координації між освітою і роботодавцями, втрати престижності робітничих професій, низької якості освітніх послуг для підприємців, націлених на освоєння сучасних технологій. У результаті зменшується кількість охочих вступити до професійно-технічних навчальних закладів (ПТНЗ) і випуск ними кваліфікованих працівників. Порівняно з 2000 роком чисельність кадрів, які одержали професії в ПТН3, скоротилась на 125,5 тис. осіб (рис. 1) [7].

Рівень безробіття випускників ПТНЗ є найвищим серед тих, хто закінчив будьякий навчальний заклад і здобув відповідну освіту (рис. 2) [8]. У 2017 році на ринку праці серед випускників начальних закладів, які не змогли працевлаштуватись, ПТНЗ складали 37 \%. Фактично частка безробітних випускників ПТНЗ має не тільки найбільший рівень серед випускників закладів освіти, але й висхідну динаміку.

Протягом 2000-2017 років професійно-технічна освіта функціонувала в умовах фінансових обмежень порівняно зі зростанням фінансових ресурсів в освітню галузь у цілому. Загальні видатки зведеного бюджету в освіту підвищились з 14,7 \% до $16,8 \%$. У професійну-технічну, навпаки, зменшились із 0,9\% до 0,8 \%. Найбільше зросло фінансування загальної середньої освіти: з 2000 до 2017 року майже на $51 \%$ [9]. Фінансові вливання в загальну середню освіту не пов’язані з навчанням учнів професійних навичок із метою полегшення їх працевлаштування після закінчення середньої школи (рис. 3).

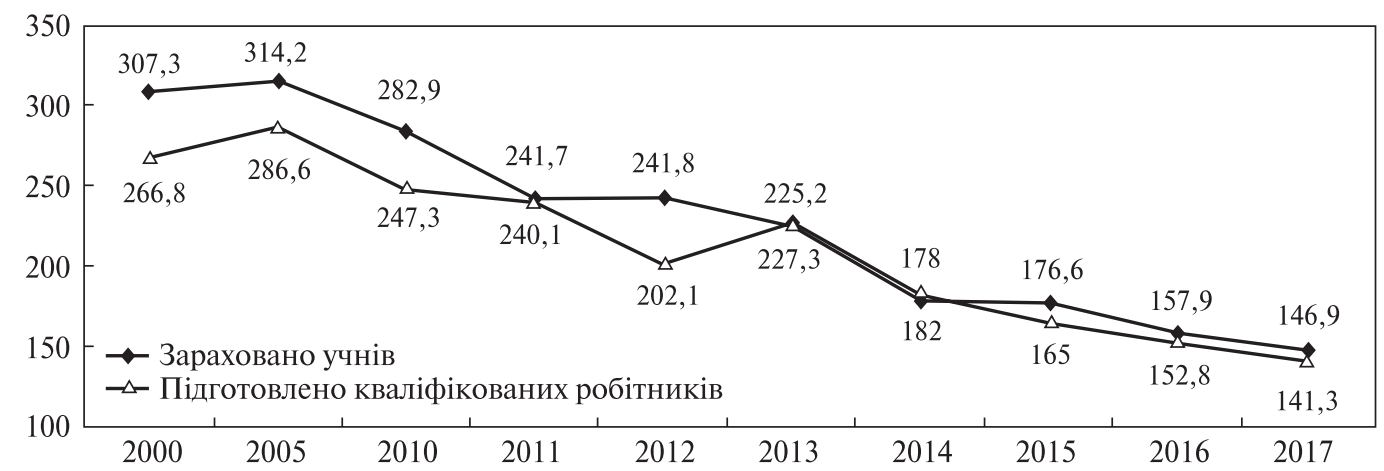

Рuc. 1. Динаміка показників роботи професійно-технічних навчальних закладів, тис. осіб

Джерело: Статистичний щорічник України за 2017 рік. - Київ: 2018. - 541 с. 


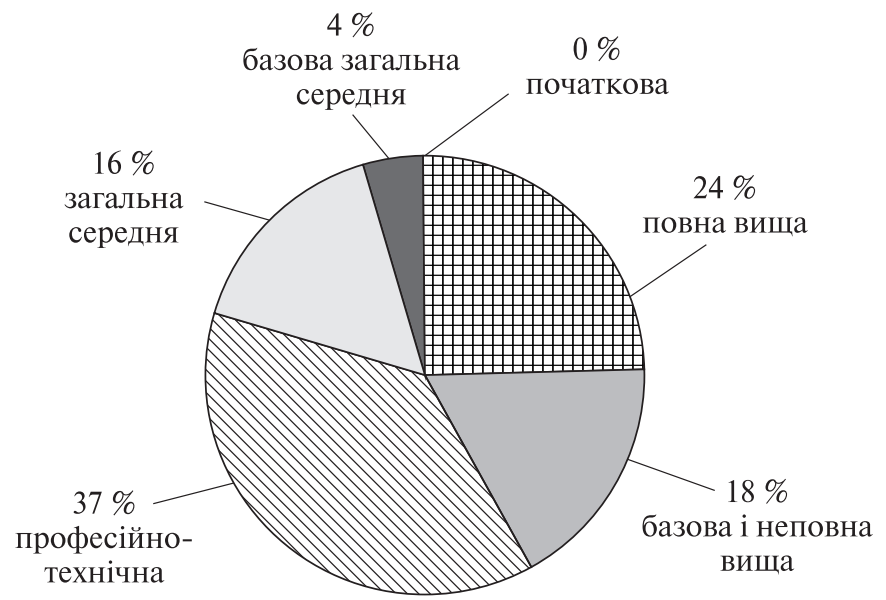

Рис. 2. Питома вага безробітних випускників навчальних закладів у 2017 році, \%

Джерело: Національна доповідь про стан і перспективи розвитку освіти в Україні / За ред. В.Г. Кременя. - Київ, $2016-448 \mathrm{c}$.

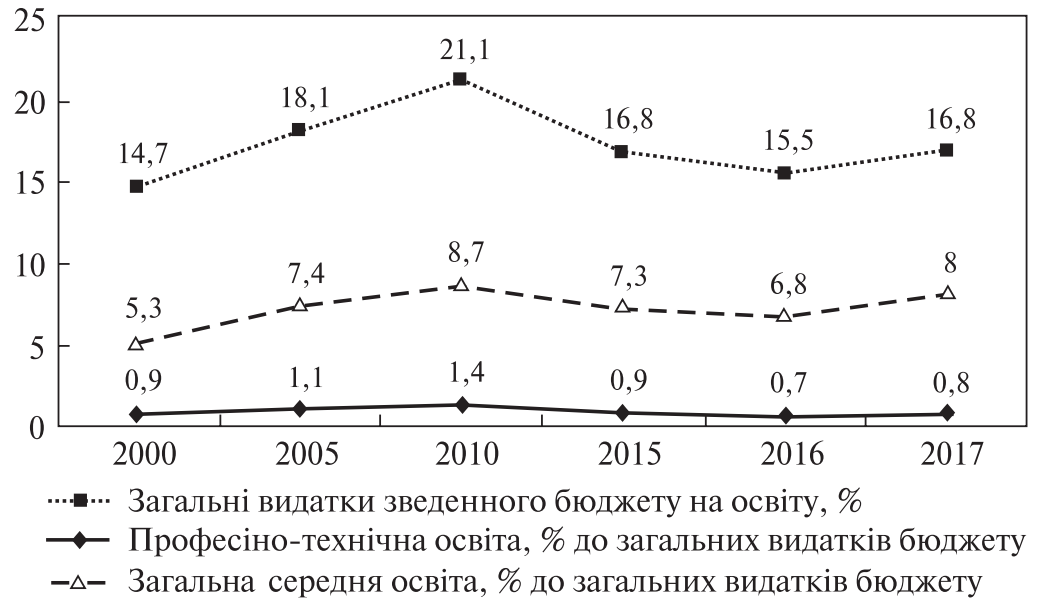

Рис. 3. Питома вага видатків Загального бюджету України на освіту

Джерело: Заклади освіти та професійно-технічного навчальні заклади. 2017. Стат. зб. - Київ, 2018. - 135 с.

Навчання учнів спрямоване на формування предметних компетентностей, а також деяких ключових компетентностей, наприклад, комунікативність. Проте освітні стандарти оцінювання результатів навчання не містять критеріальної основи їх вимірювання, що призводить до утруднень у вивченні рівня навчальних досягнень учнів. Зберігається типологічне розмаїття навчальних предметів і курсів, недосконалість структурованого змісту, особливо в старшій школі, що перешкоджає задоволенню потреб, зумовлених подальшими життєвими планами та орієнтацією на майбутню професію. Пошук національних моделей профілізації старшої школи як одна із визначальних засад іiї ефективного функціонування в сучасних умовах відбувається недостатньо та зі значними труднощами [10]. 
Забезпечення підготовки випускників за професійними напрямами загальна середня освіта навіть за належної організації діяльності може виконувати лише частково. Вирішення цього питання потребує зосередження уваги на розвитку спеціальної професійної освіти. За останні роки в системі ПТНЗ спостерігалися негативні тенденції: скорочення мережі та контингенту учнів, повільне оновлення переліку напрямів професійної підготовки, зменшення обсягів державного замовлення та фінансування професійної освіти. Якість професійної підготовки кваліфікованих робітників і молодших спеціалістів в Україні здебільшого перестала відповідати вимогам сучасного ринку праці. В країні існує незадоволений попит з боку роботодавців на професії високого рівня кваліфікації: металістів (токарів, фрезерувальників, слюсарів, водіїв автотранспорту, робітників з ремонту електричного обладнання та ін.). Потреба в робочій силі у більшості областей України задовільнена лише на 30-37 \%. Машинобудування потребує робітників 5-6 розрядів, тоді як випускники профтехосвіти здебільшого мають третій розряд. Особливо гостро кваліфікаційний дисбаланс у підготовці робітників відчувається на металообробних підприємствах [11].

Обмеженість бюджетних видатків зумовлює подальше загострення проблеми кадрового забезпечення розвитку національної економіки. Бюджети закладів професійно-технічної освіти реально є бюджетами не розвитку, а виживання: 90 \% видатків становлять заробітна плата, стипендіальне забезпечення, харчування, оплата енерго-, тепло- та водопостачання. Лише 10 \% - видатки розвитку навчального закладу. Дефіцит фінансових ресурсів професійно-технічної освіти зумовлює пошук нових моделей функціонування відповідних закладів та організації навчально-виховного процесу. Подолання неадекватності системи фінансування ПТНЗ і активізація їх модернізаційного розвитку потребують підтримки держави і підприємницького сектору економіки. Серед найважливіших завдань - підвищення ефективності кадрової політики держави на основі удосконаленого механізму функціонування професійно-технічної освіти.

Дефіцит висококваліфікованих робочих кадрів є однією з ключових перешкод, що заважає українським підприємствам оновлювати технологію виробництва, а територіальним утворенням - забезпечувати умови для інвестиційної привабливості регіонів. Подолання інерційності ПТНЗ полягає у переході від традиційної до цільової моделі підготовки робітників. Це підтверджується зарубіжним досвідом функціонування професійної освіти у форматі мережевої взаємодії освітніх закладів і підприємств у реалізації програми розвитку нових форм навчання.

Такий досвід існує у багатьох країнах, але найширше розповсюджена німецька модель. Німецьку систему практико-орієнтованої підготовки кадрів («дуальну освіту») упровадили Австрія, Канада, Китай, Румунія, Швеція, Швейцарія, Росія та інші країни. «Дуальна система» як наукова дефініція - це основний принцип здійснення перетворень у системі професійної освіти, який установлює взаємодію між органами державної влади, підприємствами і освітніми закладами через механізм державноприватного партнерства. Проте, приклад Німеччини, зміст якого полягає у цілісності і системності, не став повним аналогом для країн, які обрали цю модель для себе, оскільки кожна з них має власні економічні і регіональні особливості.

В Україні кадрова політика на основі дуальної методології стає ключовим пріоритетом з 19 вересня 2018 року, коли Кабінет Міністрів України схвалив Концепцію підготовки фахівців за дуальною формою здобуття освіти [12]. За прогнозами Міністерства освіти і науки України, впровадження дуальної освіти можливе не раніше, ніж за п’ять років. Початковим кроком урядових структур стало розроблення плану заходів, спрямованих на удосконалення системи професійної освіти [13]. 
Однак визнання і копіювання міжнародного досвіду не вирішує економічних і соціальних питань підготовки професійних кадрів. Ефективним механізмом упровадження дуальної моделі освіти може стати адміністративна політика формування сприятливих умов діяльності суб'єктів дуальної освіти, яка водночас буде фактором реалізації моделі. Ознайомлення з переліком зазначених заходів свідчить, що вони недостатньо відображають зміст інституціональних змін, характерних для практикоорієнтованого підходу до підготовки професійних кадрів. У зв’язку з цим корисно проаналізувати практику Німеччини з застосування інституту дуальної освіти та іiі регулювального впливу на розробку відповідного економіко-правового інструментарію.

Німецькій дуальній системі професійної орієнтації, самовизначення і навчання притаманна колегіальність ухвалення рішень. На всіх етапах освітнього процесу між певними функціональними структурами (федеральною і земельними владою, підприємствами, центром компетенцій, професійною школою і торгово-промисловими палатами) існує взаємодія, науково-методичне забезпечення якої здійснює Федеральний інститут професійної освіти Німеччини. Такий підхід забезпечує якісний результат професійної діяльності. Виробниче навчання відбувається як у професійно-технічних закладах, центрах компетенцій, так і на підприємствах на основі проблемно-аналітичного методу надання матеріалу [14].

Законодавчою основою дуального навчання в Німеччині є федеральний закон «Про професійну освіту», який містить два важливі поняття, які відображають сутність і визначають загальний підхід до перебудови освітньої системи. - «навчальне підприємство» і «компетенція».

Навчальному підприємству надано адміністративні функції навчального закладу, хоча ці структури не тотожні. Цим забезпечено гнучкість і визначено цільове призначення дуального навчання. Підприємство, на якому триває навчання, контролює відвідування закладу, успішність освоєння навчальних програм, організує атестацію в торгово-промисловій і ремісничій палатах. Торгово-промислові палати беруть участь у програмі підготовки спеціалістів середньої ланки для підприємств, ремісничі - кваліфікованих робітників.

На підприємствах існують спеціальні підрозділи з питань виробничого навчання. 3 кожним учнем укладено навчальний договір, для кожного розроблено індивідуальний план на весь термін навчання. Освітній процес передбачає навчання безпосередньо на підприємстві для набуття практичних навичок і у професійнотехнічному закладі для отримання теоретичних знань з обраної професії. На основі договорів визначають кількість учнів і обсяг державної субсидії. Якщо ресурсна база «навчального підприємства» недостатня для набуття студентом необхідної кваліфікації, формується мережева навчально-виробнича структура.

Існує чотири традиційні моделі мережевого навчання: «Підприємство та підприємства-партнери»; «Професійна підготовка на замовлення»; «Учбовий консорціум»; «Учбова асоціація». Вони функціонують на спільних принципах: партнерства, ротації та грошового відшкодування. Додатково до них організовано Центр компетенцій як проміжну ланку навчання, де учні одержують первісні професійні навички.

В основу організації освітнього процесу на підприємствах і у професійних закладах покладено регламенти професій, які є офіційними документами розроблення навчальних програм. У регламентах професій виокремлено два види компетенції: загальнопрофесійні і профільні. Компетенції, незалежні від конкретної професійної діяльності, є загальнопрофесійними. Поняття компетенції у диференційованій формі 
введено в Закон «Про професійну освіту» у 2005 році, що розширило правове визначення «знань і вмінь», необхідних для оцінки виробничої діяльності. Законодавча фіксація поняття «компетенції» сприяла тому, що кваліфікаційна характеристика навчального процесу в німецькій системі дуальної освіти визначається за трьома стандартами: професійними, освітніми і кваліфікаційними.

Прогресивність дуальної системи Німеччини полягає в тому, що професійні стандарти комбінуються з освітніми та кваліфікаційними стандартами. Професійні стандарти описують типові компетенції для певної професії, окремо їх не розробляють, але враховують у процесі розробки освітніх і кваліфікаційних стандартів. Таким чином, дуальна система регулює навчання на підприємстві і в навчальних закладах як процес, а не як результат виконання кількісних норм. Норми і вимоги окремо покладено в основу оцінки якості і присудження професійних кваліфікацій за результатами іспитів. Загальні правила їх проведення закріплені в Законі «Про професійну освіту» Німеччини. Організація екзаменів є функцією торгово-промислових і ремісничих палат, що дає можливість виявити деякі проблемні питання і акцентувати увагу на їх вирішенні.

Досвід Німеччини свідчить, що для побудови професійних стандартів і навчальних професійних програм потрібен новий дидактичний підхід до розробки структури професійного профілю. Професійні профілі, орієнтовані на аудиторне теоретичне навантаження, необхідно замінити професійними профілями, значною мірою орієнтованими на виробничі процеси. Професійні профілі тотожні поняттю «трудової функції працівника», якого немає у Кодексі законів про працю України, що не відповідає сучасному розумінню професійних і освітніх стандартів. Трудова функція працівника, заснована на компетенціях, забезпечує гнучкість освітніх програм і можливість працевлаштування, зменшення витрат на навчання та перенавчання робітника у випадку зміни місця праці. Фінансування професійної підготовки на підприємствах забезпечується коштами бюджету федеральних земель, навчання в учбових закладах - муніципального (місцевого) бюджету.

Результати реалізації проекту дуальної освіти в Німеччині показали, що вирішення проблеми лежить у сфері логічного визначення ключових пріоритетів державного управління системою професійної підготовки кадрів. Це має важливе значення для України, оскільки у багатьох регіонах підготовка кадрів слабо реагує на економічні перетворення і характеризується інертністю професійних освітніх організацій.

За результатами анкетування роботодавців укладено та обгрунтовано перелік компетенцій, яким має відповідати сучасний конкурентоспроможний правник. Це - кваліфікація, професійна компетенція, постійне самовдосконалення, професійна мобільність, швидка адаптація до змін виробничих умов, опанування сучасних виробничих технологій, знання IKT [15, с. 22]. Високому рівню компетенцій мають відповідати професії, на які існує стабільний попит роботодавців: слюсарі, токарі, фрезерувальники, електрогазозварники, водії автотранспортних засобів, робітники з ремонту електричного обладнання, інші дефіцитні нині спеціальності. Проте ПТНЗ не можуть задовольнити попит роботодавців, перш за все, з причини соціальної непривабливості робочих професій для молоді, що зумовлено: складністю трудової адаптації в колективі, незадовільними умовами працевлаштування, суспільною непрестижністю посади, невизначеністю кар'єрного зростання тощо. В дуальній моделі ці проблеми, як свідчить німецький досвід, нейтралізуються інститутом наставництва. 
Наставництво - це цілеспрямована діяльність керівників і найбільш досвідчених співробітників підприємства, спрямована на підготовку стажистів до самостійного виконання службових обов'язків. Як трудова функція наставництво може бути включено в посадові обов'язки працівника. 3 одного боку, цей інститут відображає високі вимоги до компетенцій, закріплених офіційними документами на федеральному рівні. 3 іншого боку, - забезпечення сталого позитивного іміджу, престижу професії в суспільстві і кар'єрного зростання. Для запозичення німецького досвіду і адаптації елементів дуального навчання з урахуванням особливостей України важливо розширити комплекс заходів з удосконалення професійної освіти. Головними завданнями підготовки законодавчих проектів є розроблення сучасної моделі і формування мережевої взаємодії освітніх закладів і підприємств з підготовки професійних кадрів і стимулювання роботодавців до фінансування навчальних програм.

Дуальну освіту як відомий світовий бренд можна трактувати у вузькому і широкому значенні. У вузькій трактовці організація освітнього процесу поєднується з практичним навчанням на підприємстві безальтернативно, незалежно від умов сучасного економічного укладу й економічної моделі розвитку. Зокрема, розглядаються принципи побудови дуальних програм у німецьких професійних школах, оцінюються переваги даної форми для учнів і роботодавців. У широкому контексті проблематика дуальної освіти спрямована не тільки на врахування інституційних умов, в яких відбувається відтворення людського капіталу, але й умов, що забезпечують координацію суб’єктів ринкової економіки з метою зацікавлення їх у інвестуванні коштів у професійну підготовку працівників [16].

Координаційну функцію у питаннях підготовки кадрів виконують торгово-промислові палати. Їхня роль полягає у захисті інвестицій роботодавців у підвищення кваліфікації кадрів, зниження ризику відтоку робітників з підприємств і переходу їх до конкурентів. В умовах українського ринку праці з його плинністю кадрів і високою міграцією підприємці, як правило, не можуть розраховувати на стабільну зайнятість працівників, які пройшли навчання. Це не стимулює їх брати на себе фінансові зобов’язання з навчання молодих співробітників. Оцінюючи ситуацію в сфері професійної освіти в Україні, де вплив профспілок і об’єднання роботодавців на ситуацію на ринку праці незначний, важливо для впровадження дуальної освіти визначити не тільки інституціональні структури, здатні відповідати за ризики, пов’язані з інвестиціями в систему професійної освіти, але й управлінські, організаційні і фінансові механізми підтримки нової моделі підвищення кваліфікації.

Німецький досвід засвідчує, що інституційне оформлення практики дуальної освіти може мати свої особливості в кожній країні. Це зобов’язує до передбачення можливостей і обмеження поширення цієї моделі в Україні. В Німеччині з 90 \% компаній, які мають дозвіл на навчання на виробництві, лише 21 \% підприємств пропонують професійне навчання. Обмеження дуальної моделі підготовки кваліфікованих кадрів полягає насамперед в економічній площині: нерівномірність динамічного зростання регіональних економік, несприятлива економічна кон'юнктура, відсутність умов для технологічного переозброєння виробництва, галузеві межі, де принципи і методи дуальної системи не можуть бути уповноваджені (медицина, педагогіка, мистецтво та інші), недостатній досвід державно-приватного партнерства. Однак широкомасштабному впровадженню дуального навчання сприяють стійкий попит на кваліфіковану робочу силу, здійснення інвестиційної регіональної політики, наявність високотехнологічних секторів у промисловості та в аграрному виробництві, кооперація професійних закладів із підприємствами на основі кластерного підходу. 
В Німеччині інвестиції у високотехнологічні кластери розподілено між державою і роботодавцями у пропорції 50 : 50. За відсутності великих інвестиційних проектів частка роботодавців у структурі доходів професійно-технічних закладів складає $10-$ $20 \%$. Навчальні заклади, орієнтовані на підготовку кадрів для малого та середнього бізнесу і для підприємств із традиційною технологією, утворюють третю кластерну групу дуальної освіти. Можливості взаємодії навчальних закладів і роботодавців у цьому кластері незначні.

3 урахованням німецького досвіду можна стверджувати, що включення моделі дуальної освіти у технологічний розвиток економіки України передбачає удосконалення правил і законодавчих умов реформування професійної освіти на базі мережевої взаємодії ПТНЗ та підприємств. У даному контексті важливо орієнтуватись на галузеві потреби економіки у підготовці кадрів і формування державного замовлення на навчання, що відповідатиме пріоритетним напрямам розвитку ринку праці. Оскільки Україна нині перебуває лише на підготовчому етапі розробки практико-орієнтованої моделі навчання, Німеччина може бути прикладом того, яке місце на ринку відведено новій формі освіти. Так, у «країні-першовідкривачі» дуальної освіти з 3,6 млн підприємств за цією програмою навчання працює 500 тис. (13,9 \%), при цьому понад половина - це малі і середні підприємства [17]. Найбільше пропозицій дуального навчання стосуються інженерних спеціальностей, інформатики, бізнес-адміністрування. Останнім часом з'являється попит на соціальні і медичні професії, зокрема ерготерапія, геріатрія [18].

Виходячи з цілей і результатів реалізації практико-орієнтованої моделі освіти в Німеччині, можна сказати, що сьогодні дуальне навчання є найперспективнішим спрямуванням у підготовці фахівців для реального сектору економіки за участю великого бізнесу з високотехнологічним виробництвом з урахуванням міжнародних стандартів якості продукції і кваліфікації кадрів.

В Україні ринок праці не має інноваційного характеру [19, с. 2]. У державній службі зайнятості на початок 2018 року налічувалось 50,4 тис. вакансій та ще 39 тис. пропозицій надійшло з інших джерел. За регіональною структурою понад $40 \%$ вакансій припадало на чотири регіони (Київ, Львівську, Київську та Дніпропетровську* області) [20]. За видами економічної діяльності найбільше вакансій є на підприємствах та в установах переробної промисловості (23\%), у торгівлі та ремонті автотранспорту (16\%), на транспорті (11\%). Фактично $50 \%$ пропозицій ринку праці припадає на галузі, які не є пріоритетними для технологічного оновлення економіки на основі концепції «нової індустріалізації». Незадоволено попит ринку праці на традиційні спеціальності: швачки, електромонтери, слюсарі, токарі, муляри, продавці, кухарі, офіціанти, бармени тощо. Це показує, що в умовах традиційної структури економіки, по-перше, існує критичний дисбаланс на ринку праці, пов'язаний переважно із попитом на наскрізні спеціальності; по-друге, економіка не пред'являє помітних запитів на робочу силу нових технологічних укладів.

Ситуацію погіршує те, що професійно-технічна освіта проходить етап реформ i навчальний процес ще не адаптовано до вимог підготовки кадрів для інноваційної економіки. До нових технологічних складних професій за інерцією зараховують операторів телекомунікаційних послуг, укладальників підлогового покриття, підручних сталеварів конвеєрного виробництва, майстрів ресторанного обслуговування, монтажників будівельних, деревообробників будівельних тощо, які, за прикладом

* Дніпропетровську область з 2019 року перейменовано на Січеславську. 
Німеччини, є складовими другого та третього кластеру дуальної освіти [21, с. 19]. У їхніх межах важко вирішувати проблему мотиваційного стимулювання розвитку соціального партнерства для підготовки кваліфікованих кадрів.

Наявна система професійної освіти має високий рівень інерційності у сфері впровадження освітніх технологій і недосконалі механізми забезпечення якості навчання, що не дає змоги адаптувати випускників до вимог роботодавців. Проте зміни, що назріли у професійно-технічній освіті, потребують невідкладного і зваженого переходу від традиційної до цільової моделі підготовки кадрів для виробництва.

Висновки. Для того, щоб дуальна освіта стала найперспективнішою формою навчання, необхідно мати мінімальний набір програмних заходів: цільове замовлення фахівців на основі середньо- і довгострокового прогнозу кадрових потреб; двоєдиний принцип формування професійних освітніх програм на базі освітнього стандарту і корпоративного професійного стандарту; упровадження міжнародних стандартів у професійні освітні програми; оцінка якості професійних кваліфікацій.

Послідовній реалізації практико-орієнтованої (дуальної) освіти сприятимуть такі фактори: створення колегіального органу, що здійснює оперативне планування і контроль за впровадженням дуальної моделі освіти; розробка комплексної стратегії розвитку освіти з урахуванням окремих цілей і ключових показників ефективності для системи професійної освіти; переформування освітніх організацій у ресурсні центри професійного навчання для підвищення престижу робітничих професій та спеціальностей з визначенням пріоритетних напрямів підготовки для кожного освітнього закладу; створення єдиної системи стандартів робітничих професій 3 точки зору вимог до вмінь, знань, компетенції та кваліфікацій, а також уніфікація освітніх програм; активне просування в регіонах робітничих професій у взаємодії освіти і системи професійної освіти; сприяння залученню фінансування розвитку учасників кластеру дуальної освіти.

Забезпечення відповідності кваліфікації випускників професійно-освітніх закладів запитам роботодавців потребує законодавчої підтримки. По-перше, підготовки списку перспективних і затребуваних на ринку праці професій та спеціальностей, що вимагають середньої професійної освіти. По-друге, розробки та впровадження професійних стандартів найбільш перспективних і затребуваних професій і спеціальностей, у тому числі відповідно до кращих закордонних стандартів та передових технологій. По-третє, державної підтримки модернізації системи середньої професійної освіти в формі державних субсидій, наданих для реалізації регіональних програм розвитку професійно-освітніх закладів.

\section{ЛІТЕРАТУРА}

1. Кучинський М. Формуємо передумови для відродження престижності професійної освіти // Професійно-технічна освіта. - 2018. - № 1. - С. 7-9.

2. Луцька А. Законотворчий процес про професійну освіту // Професійно-технічна освіта. 2018. - № 3. - С. 5-9.

3. Пятничук Т. Дуальна система професійної підготовки фахівців: аналіз досвіду // Професійнотехнічна освіта. - 2018. - № 3. - С. 27-31.

4. Кудря К., Сталінська О. Упровадження елементів дуальної форми навчання: переваги та проблеми // Професійно-технічна освіта. - 2018. - №2. - С. 17-19.

5. Новіков В.M. Розвиток професійної-технічної освіти в умовах децентралізації системи управління в Україні // Демографія та соціальна економіка. - 2017. - № 2 (30). - 127-137 с. https://doi.org/10.15407/dse2017.02.126

6. Каленюк I.C. Державна фінансова підтримка розвитку професійної підготовки: світовий досвід // Банківська справа. - 2001. -№ 5. - С. 44-47. 
7. Щорічник України за 2017 рік. - Київ, 2018. - 541 с.

8. Економічна активність населення України. - Київ, 2018. - 204 с.

9. Загальноосвітні навчальні заклади України на початок 2016/2017 років навчального року. Стат. бюлетень. - Київ, 2017. - 100 с.

10. Національна доповідь про стан і перспективи розвитку освіти в Україні. / За заг. ред. В.Г. Кременя. Нац. акад. педагог. наук України. - Київ, 2016. - 448 с.

11. Новіков В.М. Модернізація професійно-технічної освіти як цільова функція розвитку ринку праці в Україні // Prospon - Instytut Studiow Miedzynarodowy i EdukacjiwWarszawie. № 20 (3). - 2017. - C. 105-118.

12. Концепція підготовки фахівців за дуальною формою здобуття освіти [Електронний pecypc]. - Режим доступу: https://www.kmu.gov.ua (дата звернення: 11.01.2019).

13. Про затвердження плану заходів з реалізації Концепції підготовки фахівців за дуальною формою здобуття освіти (проект): Розпорядження Кабінету Міністрів України [Електронний ресурс]. - Режим доступу: http://spo. fpsu.urg.ua/images/2018/2018/4150-сайт.pdf (дата звернення: 11.01.2019).

14. Методические рекомендации по реализации дуальной модели подготовки високо квалифицированых робочих кадров. / Агенство стратегических нициатив. - 2015. - 136 с. [Електронний pecypc]. - Режим доступу: http://permtpp.ru/upload/iblock/dfe/metodicheskie-rekomendatsii_ dualnoe-obrazovanie_2015.pdf (дата звернення: 11.01.2019).

15. Селізар В. Освітній маркетинг у діяльності ПТНЗ // Професійно-технічна освіта. - 2016. № 3.- C. 20-23.

16. Remington T. F., Marques I. The Reform of Skill Formationin Russia: Regional Responses. Higher School of Economics Research. -2014. Paper No WP BRP 19/PS/2014. [Електронний pecypc]. - Режим доступу: https://papers.ssrn.com/sol3/papers.cfm?abstract_id=2530875\#\# (дата звернення: 01.01.2019)

17. Петерсен А. Вилли, Йепсен Маик. Подход и опыт разработки профессиональных стандартов в Германии / А. Вилли Петерсен, Маик Йепсен. - Флесенбург, 2015. - 48 с. [Електронний peсурс]. - Режим доступу: http://fru.org.ua/ua/events/business-events/ukrainski-promyslovtsirazom-iz-providnymy-tekhnichnymy-universytetamy-pereimaiut-dosvid-dualnoi-osvity-u-svoikhnimetskykh-koleh (дата звернення: 11.01.2019).

18. Куделя Н. Дуальное образование в Германии: плюсы и минусы [Електронний ресурс]. - Режим доступу: https//www.partner-inform.de/.../dualnoe-obrzovanie-v-germanii-hlusy-i-minusy (дата звернення: 11.01.2019).

19. Ковтунець В., Хобзей П., Кремень В. та ін. Сучасна професійна освіта. Концептуальні засади реформування професійної освіти України // Професійно-технічна освіта. - 2018. - № 2. C. 2-11.

20. Супрун В. Актуальні питання розвитку та модернізації професійної (професійно-технічної) освіти України // Професійно-технічна освіта. - 2018. - № 2. - С. 10-13.

21. Радкевич $B$. Науково-методичне забезпечення модернізації професійної підготовки фахівців: результати наукових досліджень // Професійно-технічна освіта.- 2018. - № 2. - С. 18-23.

\section{REFERENS}

1. Kuchyns'kyi, M. (2018). Formuemo peredymovu dlj vidrodzhenj prestizhosni profesiinoi osvitu [We form the prerequisites for the revival of the prestige of vocational education]. Profesijno-tehnichna osvita - Vocational and technical education, 1, 7-9 [in Ukrainian].

2. Lucyka, A. (2018). [Zakonotvorcheii proches pro profesiiny osvity [Legislative process on vocational education]. Profesijno-texnichna osvita - Vocational and technical education, 3, 5-9 [in Ukrainian].

3. Pjtnichuk, T. (2018). [Dyalna sistema profesiinoii pidgotjvki fahivchiv: analiz dosvidu [Dual system of professional training: analysis of experience]. Profesijno-texnichna osvita - Vocational and technical education, 3, 27-31 [in Ukrainian].

4. Kudrj, K., \& Stalinska, O. (2018). [Implementation of elements of the dual form of learning: advantages and problems]. Profesijno-texnichna osvita - Vocational and technical education, 2, 17-19 [in Ukrainian]. 
5. Novikov, V. (2017). [Development of vocational education in a decentralized management system in Ukraine]. Demohrafiya ta sotsial'na ekonomika - Demography and Social Economy, 2 (30), 127-137. https://doi.org/10.15407/dse2017.02.126 [in Ukrainian].

6. Kalenuk, I.S. (2001). [Derjavna finansova pidtrumka rozvutky proaesinoiipid pedgotovku: svitovuii dosvid]. Bankevska sprava - Banking, 5, $44-47$ [in Ukrainian].

7. Shchorichnyk Ukrainy 2017 [The Yearbook of Ukraine for 2017] (2018). Kyiv [in Ukrainian].

8. Ekonomichna aktyvnist naselennia Ukrainy [Economic activity of the population of Ukraine] (2018). Kyiv [in Ukrainian].

9. Zahalnoosvitni navchalni zaklady Ukrainy na pochatok 2016/2017 rokiv navchalnoho roku [Educational institutions of Ukraine at the beginning of 2016/2017 academic year]. (2017). Kyiv [in Ukrainian].

10. Kremen', V.G. (Eds.). (2016). Nacional'na dopovid' pro stan i perspektyvy rozvytku osvity v Ukrayini [National report on the status and prospects of education in Ukraine]. Kyiv [in Ukrainian].

11. Novikov, V. (2017). Modernizatsiia profesiino-tekhnichnoi osvity yak tsilova funktsiia rozvytku rynku pratsi v Ukraini [Modernization of vocational education as a target function of the labor market development in Ukraine]. Prospon-ProSpon, 20 (3), 105-118 [in Poland].

12. Kontseptsiia pidhotovky fakhivtsiv za dualnoiu formoiu zdobuttia osvity [Concepts of training fahivtsiv for the dual form of health]. (2018). Retrieved from http: //www.kmu.gov.ua [in Ukrainian].

13. Pro zatverdzhennia planu zakhodiv z realizatsii Kontseptsii pidhotovky fakhivtsiv za dualnoiu formoiu zdobuttia osvity (proekt): Rozporiadzhennia Kabinetu Ministriv Ukrainy [On Approval of the Plan of Measures for the Implementation of the Concept of Training Specialists on the Dual Form of Education:Order of the Cabinet of Ministers of Ukraine]. (2018). Retrieved from http: spo. fpsu.urg.ua/images/2018/2018/4150сайт.pdf [in Ukrainian].

14. Metodichtskie rekomendacyii po realizacyii dyal'noii modeli podgotovki vusokokvalifchirovanuh robochih kadrov [Guidelines for the implementation of the dual model of training highly skilled working personnel]. Retrieved from http://permtpp.ru/upload/iblock/dfe/metodicheskie-rekomendatsii_dualnoe-obrazovanie_2015.pdf [in Russian].

15. Selizar, V. (2016). Osvitniy marketynh u diyal'nosti PTNZ [Educational marketing in the activities of the PNZMarques]. Profesijno-texnicha osvita - Vocational and technical education, 3, 20-23 [in Ukrainian].

16. Remengton, T., \& Margues, I. (2014). The Reform of Skill Formationin Russia: Regional Responses. Higher School of Economics Research Paper. Retrieved from https://papers.ssrn.com/sol3/papers.cfm?abstract_id $=2530875 \# \#$

17. Petersen, A.V., \& Jepsen M. (2015). Podxod i opyt razrabotki professional'nych standartov v Germanii [Approach and experience in developing professional standards in Germany]. Flesenburg. Retrieved from http://fru.org.ua/ua/events/business-events/ukrainski-promyslovtsi-razom-iz-providnymy-tekhnichnymy-universytetamy-pereimaiut-dosvid-dualnoi-osvity-u-svoikh-nimetskykh-koleh [in Russian].

18. Kudelj, N. (2018). Dyalnoe obrazovanie v Germnii: pliusu I minysu [Dual Education in Germany: Pros and Cons].Retrieved from https//www.partnerinform.de/.../dualnoe-obrzovanie-v-germanii-hlusy-iminusy [in Russian ].

19. Kovtunets', V., Khobzey, P., \& Kremen', V. et al. (2018). Suchasna profesiyna osvita. Kontseptual'ni zasady reformuvannya profesiynoyi osvity Ukrayiny [Modern professional education [Conceptual Principles of the Reform of Ukrainian Professional Education]. Profesijno-texnicha osvita - Vocational and technical education, 2, 10-13 [in Ukrainian].

20. Suprun, V. (2018). Aktual'ni pytannya rozvytku ta modernizatsiyi profesiynoyi (profesiyno-tekhnichnoyi) osvity Ukrayiny [Topical issues of development and modernization of professional (vocational) education of Ukraine]. Profesijno-texnichna osvita - Vocational and technical education, 2, 2-11 [in Ukrainian].

21. Radkevich, V. (2018). Naykovo-metoduchne zabezpechennj profesiinoii pidgotovku fachivcyiv: rezyl'tatu naykovuch doalidjan [Scientific and methodological provision of modernization of professional training of specialists: results of scientific research]. Profesijno-texnichna osvita-Vocational and technical education, 2, 18-23 [in Ukrainian].

Стаття надійшла до редакції журналу 18.02.2019. 


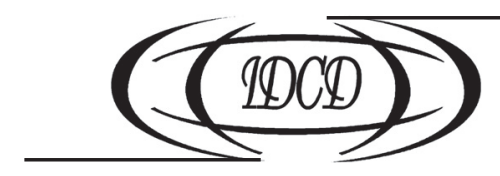

https://doi.org/10.15407/dse2019.02.165

УДК 331.5:005.332.1

JEL CLASSIFICATION: C13, J21

\section{Л.М. ІЛЬЇЧ}

д-р екон. наук, доц., зав. каф. управління

Київський університет імені Бориса Грінченка

04212, Україна, м. Київ, вул. Маршала Тимошенка, 13-Б

E-mail: ilyich_1@meta.ua

ORCID 0000-0002-8594-1824

\section{М.О. КРИМОВА}

канд. екон. наук, стар. наук. співроб.

Інститут демографії та соціальних досліджень

імені М.В. Птухи НАН України

01032, Україна, м. Київ, бул. Т. Шевченка, 60

E-mail: mariya.krymova@gmail.com

ORCID 0000-0002-9753-9672

\section{МЕТОДИКА ОЦІНЮВАННЯ КОНКУРЕНТОСПРОМОЖНОСТІ РОБОЧОЇ СИЛИ}

Мета роботи полягала у розробці авторської комплексної методики оцінювання конкурентоспроможності робочої сили на рівні регіонів. Запропонована методика побудована з урахуванням принципів достовірності, обгрунтованості, надійності, послідовності у часі та імплементації. Процес оцінювання здійснюється в чотири етапи та враховує об'єктивні і суб'єктивні (отримані в ході експертного опитування) показники. Перший етап базується на дослідженні змісту категорії «конкурентоспроможність робочої сили» та визначенні комплексу чинників, що впливають на процеси ї̈ формування та реалізації. Чинники впливу систематизовано за змістовними та цільовими ознаками, що уможливило виокремлення груп оціночних показників. Другий етап методики передбачає формування інформаційної бази, перевірку достовірності та оцінювання інтегральних індексів конкурентоспроможності робочої сили регіонів з урахуванням ваги впливу комплексних індикаторів оцінки на підсумковий. Третій етап охоплює аналіз розрахунків регіональних відмінностей за рівнем розвитку комплексних показників, проведення ранжування та групування регіонів, як за рівнями конкурентоспроможності робочої сили, так $і$ за субіндексами їі компонентів (демографічного, освітньо-професійного, економічного, кон'юнктурного, технологічного та інфраструктурного) з подальшим картографуванням отриманих результатів. Четвертий етап передбачає доопрацювання результатів аналізу, визначення чинників, що перешкоджають реалізації конкурентоспроможності робочої сили та стримують ї̈ нарощування, $а$ також послідовну розробку практичних рекомендацій, спрямованих на посилення ефективності процесів іï формування та реалізації. Особливістю розробленої методики є ииклічність процесу оцінювання, що розширює можливості для впровадження моніторингових досліджень у цій сфері та посилює аргументованість управлінських рішень, пов'язаних з формуванням та реалізацією конкурентоспроможності робочої сили регіону.

Ключові слова: конкурентоспроможність, робоча сила, методика, інструментарій, оцінювання, ринок праці, регіон.

(с) ІЛЬЇЧ Л.М., КРИМОВА М.О., 2019

ISSN 2072-9480. Демографія та соціальна економіка, 2019, № 2 (36): 165-177 


\section{Л.Н. Ильич}

Д-р. экон. наук, доц., зав. каф. управления

Киевский университет имени Бориса Гринченко

04212, Украина, г. Киев, ул. Маршала Тимошенко, 13-Б,

E-mail: ilyich_1@meta.ua

ORCID 0000-0002-8594-1824

\section{М.О. Крымова}

канд. экон. наук, стар. науч. сотруд.

Институт демографии и социальных исследований

имени М.В. Птухи НАН Украины

01032, Украина, г. Киев, бул. Т. Шевченко, 60

E-mail: mariya.krymova@gmail.com

ORCID 0000-0002-9753-9672

\section{МЕТОДИКА ОЦЕНИВАНИЯ КОНКУРЕНТОСПОСОБНОСТИ РАБОЧЕЙ СИЛЫ}

Цель работы - разработка авторской комплексной методики оценивания конкурентоспособности рабочей силы на уровне регионов. Предложенная методика построена с учетом принципов достоверности, обоснованности, надежности, последовательности во времени и имплементации. Процесс оценки осуществляется в четыре этапа и учитывает объективные и субъективные (полученные в результате экспертного опроса) показатели. Первый этап предусматривает исследования сущности категории «конкурентоспособность рабочей силь», определения факторов, влияющих на процессы её формирования и реализации, систематизацию их в соответствии с содержательными и целевыми признаками, с последующим выделением оценочных показателей по каждому выбранному фактору. Второй этап предусматривает формирование информационной базы, проверку достоверности и оценку интегральных индексов конкурентоспособности рабочей силы регионов, с учетом веса влияния комплексных индикаторов оценки на результирующий. На третьем этапе осуществляется анализ результатов региональных различий по уровню развития комплексных показателей, анализ полученных оценок, ранжирование и группировка регионов по уровням конкурентоспособности рабочей силы в соответствии с субиндексами отдельных компонентов (демографических, образовательно-профессиональных, экономических, конбюнктурных, технологических и инфраструктурных) с последовательным картографированием полученных результатов. Четвертый этап предусматривает критический анализ полученных результатов, определение факторов, негативно влияющих на процессы наращивания конкурентоспособности рабочей силы, и разработку практических рекомендаций, направленных на усиление эффективности процессов ее формирования и реализации. Особенностью методики является цикличность процесса оценки, что способствует увеличению возможностей для проведения мониторинговых исследований в этой сфере и усиливает аргументированность управленческих решений, связанных с формированием и реализацией конкурентоспособности рабочей силы.

Ключевые слова: конкурентоспособность, рабочая сила, методика, инструментарий, оценивание, рынок труда, регион.

\section{L.M. Ilich}

Dr. Sc. (Economics), Assosiate Prof, Head of the Chair of Management

Boris Grinchenko Kiev University

04212, Ukraine, Kyiv, Marshal Timoshenko str., 13-B

E-mail: ilyich_1@meta.ua

ORCID 0000-0002-8594-1824

\section{M.O. Krymova}

$\mathrm{PhD}$ (Economics), Senior Researcher

Ptoukha Institute for Demography and Social Studies

of the National Academy of Sciences of Ukraine

01032, Ukraine, Kyiv, Taras Shevchenko Blvd., 60

E-mail: ilyich_1@meta.ua

ORCID 0000-0002-9753-9672 


\section{ASSESSMENT METHOD OF MANPOWER COMPETITIVENESS}

The article presents the author's methodology for assessing the competitiveness of the manpower at the region; on level. The methodology is promoted in accordance with the principles of certainty, reasonableness, reliability, implementation and sequence in time. In accordance with the proposed methodology, the assessment of manpower competitiveness occurs in four stages and takes into account both objective indicators and subjective ones (obtained as a result of an expert survey). The first stage deals with the studying of the category "manpower competitiveness", the determination of factors influencing the processes of its formation and implementation, their systematization and target characteristics, with a consistent selection of performance indicators for each selected factor. The second stage presents the formation of an information base, validation and evaluation of integral indices of regional manpower competitiveness, taking into account the weight of the impact of the integrated assessment indicators on the resultant. The third stage involves the analysis of the estimates obtained, the ranking and grouping of regions by their levels of manpower competitiveness and the sub-indexes of individual components (demographic,educational-professional, economic, conjuncture, technological and infrastructure) with sequential mapping of the results. The fourth stage involves the implementation of a critical analysis of the results obtained, the identification of factors that adversely affect the processes of increasing the manpower competitiveness and the development of practical recommendations aimed at the efficiency of the processes of its formation and realization. The peculiarity of the methodology is its cyclical nature of the assessment process, which increases the opportunities for conducting monitoring research in this area and strengthens the reasoning of management decisions related to the processes of formation and realization of the manpower competitiveness.

Keywords: competitiveness, manpower, methods, tools, labor market, evaluation, region.

Постановка проблеми та актуальність теми. На шляху до забезпечення стратегічних цілей України у напрямі досягнення сталого економічного розвитку однією з найбільш значущих і гострих сьогодні є проблеми якості робочої сили, утримання талантів та нарощення конкурентоспроможності людського ресурсу. У цьому контексті актуальності набувають соціально-економічні дослідження, спрямовані на вивчення передумов формування, відтворення і використання робочої сили, оцінювання іiі конкурентоспроможності.

Аналіз останніх досліджень і публікацій. Проблеми визначення сутності конкурентоспроможності робочої сили та методичні підходи до їі оцінювання активно розробляються науковою спільнотою впродовж останніх десятиріч. В умовах прискорення інформатизації економіки, формування принципово нового розподілу праці та активізації трудової мобільності робочої сили і робочих місць, усе більший науковий інтерес до цієї проблематики пов'язаний, насамперед, із необхідністю забезпечення потреб економіки у висококваліфікованій робочій силі, здатній до нарощення конкурентних переваг як окремих регіонів, так і держави в цілому. Аналізуючи науковий доробок у цій сфері, можна умовно виокремити такі рівні оцінки конкурентоспроможності: індивідуальний (нано-), мікро-, мезо- та макрорівень.

Проблемам оцінювання конкурентоспроможності робочої сили нанорівня (iндивіда, випускника, фахівця тощо) присвячено роботи С. Кравцевич, Т. Озернікової (S. Kravtsevych, T. Ozernykova) [1], М. Семикіної, О. Смірнова (M. Semykina, O. Smirnov) [2], Д. Бурместера, Д. Хіббарда,(D. Buhrmester, D. Hibbard) [3], I. Енгельгарда, Дж. Монсаaca, (I. Engelhard, J. Monsaas) [4], П. Растоджи (P. Rastogi) [5] та ін.

Методологічні аспекти та підходи до оцінювання конкурентоспроможності робочої сили макрорівня (підприємства, організації тощо) висвітлено в роботах Н. Горностаєвої (N. Gornostaeva) [6], О. Грішнової (O. Grishnova) [7], I. Петрової (I. Petrova) [8], Р. Фатхудінова (R. Fatkhudinov) [9], I. Цвєткової (I. Tsvietkova) [10], O. Шпирко (O. Shpyrko) [7] та ін. Різнобічні аспекти формування та реалізації конкурентоспроможності робочої сили на мезо- та макрорівнях (регіону, країни) викладені у працях Е. Лібанової (Е. Libanova) [11], Л. Лісогор (L. Lisogor) [11; 12], Н. Олтона 
(N. Oulton) [13], П. Паблос (P. de Pablos) [14], Дж. Переса (J. Perez) [14], Д. Ратнікова (D. Ratnikov) [15], А. Семикіної (A. Semykina) [16], О. Цимбала (O. Tsymbal) [11], O. Яроша (O. Yarosh) [11] та ін.

Ураховуючи широкий спектр наукових розробок у цьому напрямі, варто зазначити, що наразі не існує універсальної комплексної методики оцінювання конкурентоспроможності робочої сили, яка б уможливлювала визначення регіональних розбіжностей, як за результуючим показником, так і за чинниками, котрі його визначають. Аналіз вітчизняних і закордонних досліджень у цьому напрямі дає підстави стверджувати, що оцінювання конкурентоспроможності робочої сили на практиці переважно зорієнтоване на нано- та мікрорівні. Більшість опрацьованих нами методик базуються на використанні суб'єктивних показників, враховують якісні характеристики робочої сили, проте не розглядають тенденції розвитку економіки та ринку праці, а також цінові фактори впливу на конкурентоспроможність, що є необхідною передумовою реалізації конкурентних переваг робочої сили. Нині існує об’єктивна потреба у розробці комплексного підходу до оцінки конкурентоспроможності робочої сили регіонів, що уможливило б оцінювання не тільки кількісних, а і якісних іiі складових у фазах формування і реалізації конкурентоспроможності у сфері праці. У зв'язку з цим актуальності набуває необхідність розробки комплексної моделі оцінки конкурентоспроможності робочої сили, яка б ураховувала всі вищеназвані недоліки і уможливлювала дослідження розбіжностей в рівнях конкурентоспроможності робочої сили регіонів.

Мета статті полягає у розробці авторської комплексної методики оцінювання конкурентоспроможності робочої сили на рівні регіонів, що стане надійною інформаційною базою для визначення сильних і слабких сторін у процесах формування та реалізації робочої сили й об'єктивним підгрунтям для ефективних управлінських рішень у цій сфері.

Науковою новизною роботи є розвиток методичного інструментарію оцінки конкурентоспроможності робочої сили на рівні регіону, що базується на побудові та визначенні інтегрального показника, який відображає найбільш значущі компоненти процесів іï формування та реалізації.

Методи дослідження. У процесі дослідження для узагальнення теоретичних засад оцінювання конкурентоспроможності робочої сили використано системний, структурний та абстрактно-логічний методи аналізу, а також загальнонаукові методи (аналізу, синтезу, індукції, дедукції, історичний та логічний підходи). Серед спеціальних методів використано сучасні економіко-математичні, статистично-аналітичні методи спостереження, порівняння і зведення даних, групування рядів динаміки, абсолютних і відносних величин, індексний.

Виклад основного матеріалу дослідження. Конкурентоспроможність робочої сили мезорівня є комплексною соціально-економічною категорією, що відображає рівень розвитку кількісно-якісних характеристик сукупної робочої сили (демографічних, освітньо-професійних, економічних, технологічних та кон'юнктурних), які задовольняють потреби регіону і забезпечують ефективне використання ресурсів виробництва, досягнення високої продуктивності праці та нарощення конкурентних економічних переваг.

Важливою умовою в обгрунтуванні системи оцінки соціально-економічної категорії «конкурентоспроможність робочої сили регіону», $є$ дотримання ключових принципів та вимог до ії створення, зокрема:

- достовірність - кожна оціночна модель повинна базуватися на чітких та реальних показниках, які є статистично коректними та виваженими; 
- обгрунтованість - вибір методів, підходів і показників оцінки повинен залежати від чітких взаємозв'язків у сфері дослідження та базуватися на наявній практиці використання у цій або суміжній сферах;

- надійність - ресурсні та інформаційні джерела для оцінювання мають бути загальнодоступними та достовірними з позиції дотримання основних принципів статистичних і соціологічних досліджень;

- послідовність у часовому контексті - наявні показники оцінки, які включаються до методики, повинні мати динамізм у просторово-часовому вимірі, що дасть змогу використовувати цю методику в майбутньому та виконувати порівняльні оцінки змін у часі;

- імплементація - розроблена модель оцінки повинна мати практичне значення для іiі реалізації в діяльності суб’єктів господарювання, державних, регіональних і місцевих структур управління.

На основі використання викладених принципів було побудовано авторську методику інтегральної оцінки конкурентоспроможності робочої сили на регіональному рівні (рис. 1). Методика охоплює чотири основні етапи реалізації.

Перший етап (підготовчий) передбачає визначення комплексу чинників, які можуть впливати на процес іiі формування та реалізації.

Ключовими чинниками та комплексними показниками, що впливають на конкурентоспроможність робочої сили визначено і представлено на рис. 2.

Демографічні показники характеризують ступінь конкурентоспроможності робочої сили регіону, що прямо залежить від чисельності трудового потенціалу, тривалості трудового життя, фізичного та психологічного здоров'я населення. Саме ця група показників характеризує максимально можливий обсяг робочої сили, яка бере або може вільно брати участь у підприємницькій та трудовій діяльності. Показує наявні темпи змін робочої сили країни за рахунок природного та механічного руху населення, які безпосередньо впливають на рівень конкуренції на ринку праці та загальну конкурентоспроможність робочої сили.

Демографічний компонент комплексної оцінки об’єднує вісім одиничних показників, серед яких два є стимуляторами (їхнє зростання сприяє підвищенню конкурентоспроможності робочої сили регіону) та шість - дестимуляторами (які негативно впливають на неї). До показників цієї групи віднесено: середню очікувану тривалість життя при народженні (характеризує наявний потенціал активного трудового життя населення); коефіцієнт механічного приросту / скорочення населення (характеризує рівень відтоку населення за кордон та втрату накопиченої конкурентоспроможної робочої сили); рівень смертності населення у віці від 15 до 35 років (характеризує природні втрати найбільш перспективного та конкурентоспроможного сегменту робочої сили); демографічне навантаження непрацездатного населення на працездатне, наявний потенціал робочої сили, можливості ії заміщення та необхідність виходу працездатного населення на ринок праці); самооцінку стану здоров’я населення; кількість уперше зареєстрованих випадків захворювання; рівень первинної інвалідизації; захворюваність населення на соціально небезпечні захворювання (характеризує наявний потенціал здоров'я населення для реалізації можливостей вільної конкуренції на ринку праці).

Освітньо-професійні показники є ключовою складовою оцінки конкурентоспроможності, адже від рівня освіченості, накопичених вмінь і навичок залежить рівень конкурентоспроможності робочої сили та перспективи працевлаштування на ринку праці. Ця група показників характеризує охоплення населення неперервною 


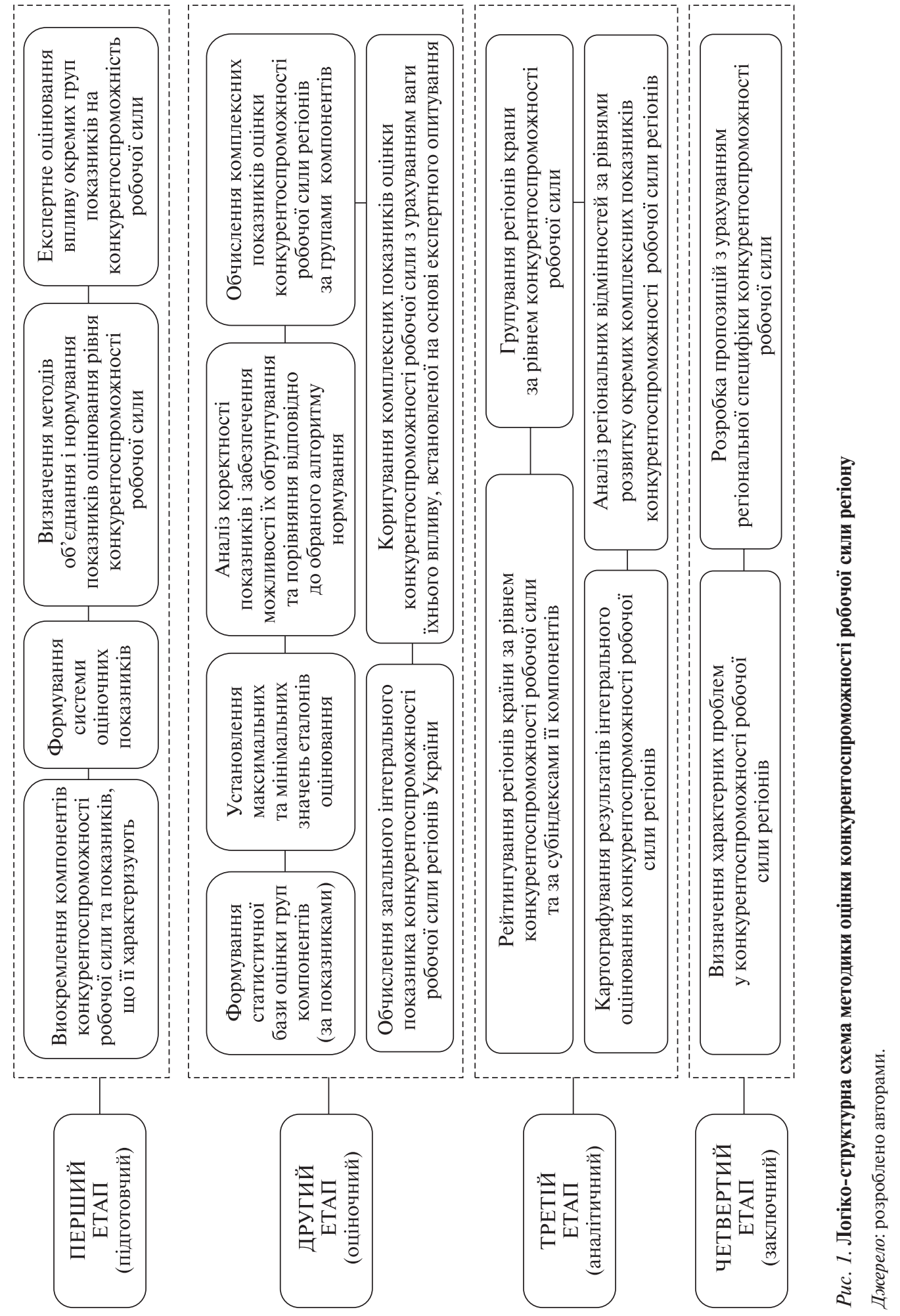




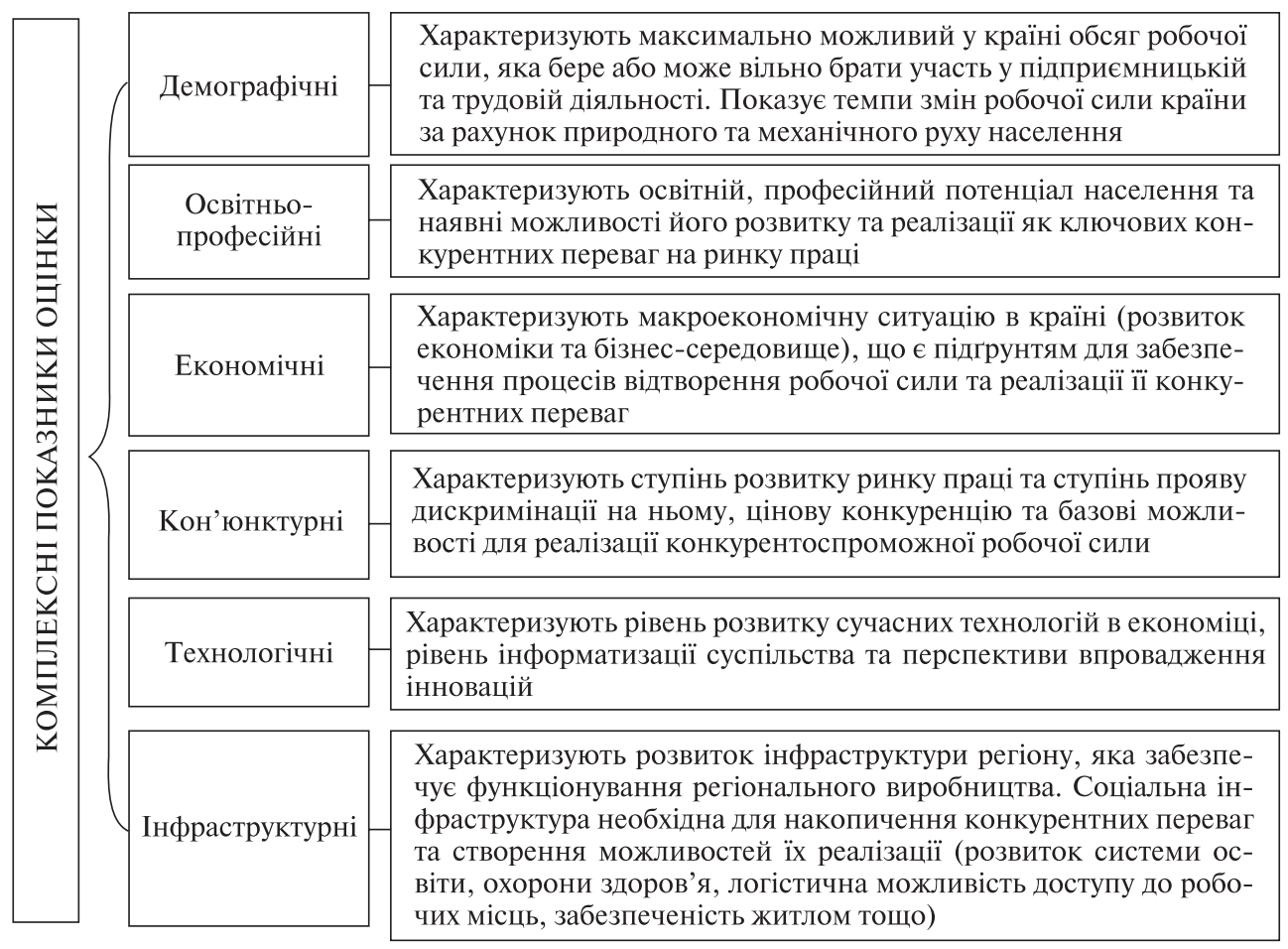

Рис. 2. Групування комплексних показників оцінки конкурентоспроможності робочої сили

Джерело: розроблено авторами.

освітою, що створює умови для підтримки належного рівня конкурентоспроможності робочої сили не лише на етапі пошуку робочого місця, а й у процесі трудової діяльності.

До основних показників оцінки освітньо-професійного компонента конкурентоспроможності належать: середній бал ЗНО (є показником оцінки рівня середньої освіти в країні та підготовленості населення до здобуття фахової освіти); частка студентів закладів вищої освіти I-IV рівнів акредитації у загальній чисельності населення (характеризує активність населення щодо здобуття вищої освіти як одного з чинників реалізації майбутньої конкурентоспроможності); кількість викладачів, що мають науковий ступінь, у розрахунку на 10000 студентів (описує наявний інтелектуальний потенціал у країні для підготовки кваліфікованої робочої сили); середня тривалість навчання осіб старше 25 років (забезпечує можливість урахування впливу навчання впродовж життя на формування конкурентоспроможності робочої сили); частка осіб з вищою освітою серед населення старше 25 років (характеризує освітній потенціал робочої сили в країні та можливості забезпечення ії вільної конкуренції).

Економічні показники характеризують макроекономічне середовище (стан розвитку економіки та бізнесу), необхідне для реалізації конкурентних переваг робочої сили та використання накопиченого людського капіталу. Окрім того, ця група показників забезпечує можливість визначити загальний рівень достатку населення та ступінь матеріальної вмотивованості працездатного економічно неактивного населення до виходу на ринок праці. 
Економічну складову комплексної оцінки характеризують такі одиничні показники: ВРП на одну особу (характеризує загальний рівень економічного розвитку регіону та ефективності використання наявного людського капіталу); індекс споживчих цін (характеризує темпи економічного зростання в регіонах); відношення середньої заробітної плати до прожиткового мінімуму (забезпечує оцінку матеріального добробуту населення, визначає вартість конкурентоспроможної робочої сили регіону, а також характеризує фінансову привабливість ринку праці регіону для конкурентоздатних осіб із інших регіонів); споживчі та неспоживчі сукупні витрати та частка населення із середньодушовими загальними доходами на місяць нижче за прожитковий мінімум (безпосередньо визначають загальний рівень добробуту населення регіону та опосередковано - необхідність для працездатного населення (як економічно активного, так і економічно неактивного) збільшувати свою конкурентоспроможність та виходити на ринок праці з метою матеріального забезпечення своєї родини).

Кон'юнктурні показники характеризують рівень розвиненості місцевих ринків праці та наявність якісних робочих місць, здатних задовольнити вимоги конкурентоспроможної робочої сили. Окрім того, зазначений блок показників покликаний оцінити прояви дискримінації у сфері праці, які не дають можливості вільно конкурувати окремим групам робочої сили.

Ця складова комплексної оцінки є однією з найважливіших у системі оцінки конкурентоспроможності робочої сили регіонів і містить найбільшу кількість одиничних показників, серед яких: навантаження на одне вільне робоче місце (уможливлює оцінку рівня конкуренції на ринку праці регіонів на окремі робочі місця, основний показник оцінки рівня розвиненості ринку праці); продуктивність праці (що забезпечує оцінку ефективності використання людського капіталу в регіоні та граничний підсумковий показник оцінки конкурентоздатності робочої сили в процесі прикладання праці); рівень зайнятості населення віком 20-64 роки (характеризує наявний потенціал економічно активної робочої сили, що реалізує свої конкурентні переваги у сфері праці); частка працівників, які зазнали впливу шкідливих факторів (характеризує якість наявних робочих місць і можливості реалізації конкурентних переваг робочої сили без шкоди для здоров'я); частка штатних працівників, що мають вищу, базову та неповну вищу освіту (забезпечує оцінку рівня конкурентоспроможності зайнятої робочої сили в економіці регіону); частка працевлаштованих віком до 35 років у загальній чисельності населення віком $15-35$ років і рівень безробіття осіб віком 25-35 років (характеризують рівень конкурентоспроможності випускників навчальних закладів, що шукають перше робоче місце та через відсутність належного професійного досвіду є менш конкурентоспроможними на ринку праці); витрати підприємств на робочу силу в розрахунку на одного штатного працівника (забезпечує оцінку якості робочих місць, наявність соціальних та компенсаційних пакетів на підприємстві, а також ціновий рівень конкуренції у регіоні); співвідношення заробітної плати жінок та чоловіків (характеризує рівень гендерної дискримінації на ринку праці регіону); частка неформально зайнятих у загальній чисельності зайнятого населення.

Технологічні показники є оціночними з погляду рівня розвитку сучасних технологій в економіці регіону та готовності наявної робочої сили створювати інноваційні та технологічні продукти, а також здатності конкурувати за високотехнологічні робочі місця.

У зв'язку з обмеженістю статистичної бази регіонів України, яка не дає можливості оцінити рівень розвитку та конкуренції у четвертинному секторі економіки країни, до технологічного блоку оцінки було обрано такі показники: фінансування 
наукових та науково-технічних робіт (характеризує пріоритетність та розвиненість упровадження інновацій та новітніх технологій); доступ населення до ресурсів Інтернет (показує рівень інформатизації суспільства та рівень обізнаності населення щодо базових інформаційних технологій, що є окремою конкурентною перевагою робочої сили); науковий потенціал регіону, що формується на базі наукових кадрів та осіб, які проходять навчання у аспірантурі чи докторантурі; коефіцієнт винахідницької активності (характеризує рівень розвитку інноваційної конкурентної переваги робочої сили та здатності створювати нові продукти та послуги); частка промислових підприємств, які реалізують інноваційну продукцію, та інноваційна активність підприємств, кількість працюючих на інноваційно активних підприємствах; питома вага підприємств із технологічними інноваціями (характеризують рівень технологічного розвитку економіки і формують вимоги до якісних характеристик робочої сили та їх подальшої конкурентоспроможності).

Інфраструктурні показники оцінки націлені на визначення рівня розвитку виробничої та соціальної інфраструктури, необхідної для накопичення та реалізації відповідних конкурентних переваг. Від рівня розвитку соціальної інфраструктури залежать можливості забезпечення здоров'я населення, відповідного рівня освіти, комфортного проживання та умов для реалізації у сфері праці.

До інфраструктурного блоку включено такі одиничні показники оцінки: індекс інвестицій у житлове будівництво (характеризує привабливість регіону для конкурентоспроможної робочої сили з погляду можливостей комфортного проживання та купівлі житла); забезпеченість населення житлом і ступінь задоволеності населення житловими умовами (характеризують якісний рівень житлового забезпечення та націленість регіональної робочої сили до переїзду в регіон з метою пошуку роботи); видатки місцевих і регіональних бюджетів на охорону здоров’я (характеризують рівень розвитку системи охорони здоров'я в регіоні, а отже, і можливості забезпечення здорового життя працездатного населення, що є окремою конкурентною перевагою); видатки регіонального та місцевих бюджетів на освіту (забезпечують можливості оцінки рівня розвиненості освіти, яка формує ключові освітньо-професійні конкурентні переваги робочої сили); обсяги перевезених вантажів і пасажирів (показує рівень розвитку транспортної інфраструктури, яка сприяє реалізації можливості працевлаштування в населених пунктах регіону з більш розвиненою виробничою інфраструктурою).

На основі експертних оцінок визначено показники стимулятивного та дестимулятивного впливу на конкурентоспроможність робочої сили. Так, до стимуляторів, що позитивно впливають на конкурентоспроможність, віднесено двадцять вісім одиничних показників оцінки, а до дестимуляторів, що характеризуються негативним впливом на конкурентоспроможність - дванадцять. Зазначений поділ показників використано для виконання процедур оцінювання інтегрального показника.

3 метою проведення комплексної оцінки усіх чинників впливу на конкурентоспроможність робочої сили було обрано індексний інтегральний метод оцінки 3 подальшим рейтингуванням регіонів.

Побудова інтегрального показника грунтується на методиці розрахунку нормованої багатомірної середньозваженої з урахуванням ваги впливу комплексних показників оцінки на підсумковий показник. Для цього використовується така формула:

$$
I_{\kappa p c}=\sum_{i=1}^{n} Z_{i j} \times a_{i},
$$


де $Z_{i j}$ - нормована багатовимірна величина за відповідною групою показників оцінки; $a_{i}$ - ваговий коефіцієнт відповідної групи показників, установлений на основі експертних оцінок, індивідуальне значення яких не повинно бути менше за нуль $\left(a_{i}>0\right)$, а сума дорівнювати одиниці $\left(\sum_{i=1}^{n} a_{i}=1\right)$.

Для нормування показників було обрано методику агрегування на розмах варіації з урахуванням попередньо встановлених порогових значень.

Відповідно до обраної методики, нормування показників-стимуляторів відбувалося за формулою:

$$
Z_{i j}=\frac{x_{i j}-x_{i \min }}{x_{i \max }-x_{i \min }},
$$

де $x_{i j}$ - значення $i$-го показника в $j$-му регіоні; $x_{i m i n}, x_{\text {imax }}-$ відповідно порогове мінімальне та максимальне значення і-го індикатора в аналізованій сукупності.

Для одиничних показників-дестимуляторів використовується формула:

$$
Z_{i j}=\frac{x_{\max }-x_{i j}}{x_{\max }-x_{\min }} .
$$

Вибір такого методу розрахунку дає змогу урахувати перспективні можливості покращення основних показників оцінки за рахунок прогнозування досягнення їх максимального та мінімального значення.

Задля встановлення вагових коефіцієнтів груп чинників, що впливають на конкурентоспроможність робочої сили, було проведено експертне опитування, яке охоплювало шістдесят науковців та фахівців-практиків у сфері соціально-трудових відносин та розвитку ринку праці, якими було встановлено такий ступінь впливу чинників: демографічні - $10 \%\left(a_{1}=0,1\right)$; освітньо-професійні чинники - $25 \%$ $\left(a_{2}=0,25\right)$; кон'юнктурні $-20 \%\left(a_{3}=0,2\right)$; економічні $-20 \%\left(a_{4}=0,2\right)$; технологічні $-15 \%\left(a_{5}=0,15\right)$; інфраструктурні $-10 \%\left(a_{6}=0,1\right)$.

Другий етап методики (оціночний) передбачає реалізацію шести основних кроків: перший - це формування сталої статистичної бази оціночних показників (окрім змістовного фактора відбору показників, до методики включено показники, які мають щорічне забезпечення офіційними статистичними даними). Такий підхід застосовано з метою уможливлення використання розробленої методики в майбутньому задля дослідження динаміки змін у сфері конкурентоспроможності робочої сили.

Другий крок - встановлення максимальних і мінімальних порогових значень одиничних показників оцінки, варіативний розмах яких складає $10 \%$ від значення найкращих і найгірших показників оцінки за останні п’ять років. На цьому ж етапі відбувається поділ одиничних показників оцінки на стимулятори і дестимулятори, що в майбутньому впливає на метод нормування показників.

Третій крок передбачає аналіз коректності індикаторів оцінки і забезпечення можливості їх обгрунтування та порівняння відповідно до обраного алгоритму нормування.

На четвертому кроці відбувається безпосереднє обчислення комплексних показників оцінки конкурентоспроможності робочої сили регіонів за групами чинників та проводиться ранжування регіонів за рівнем їх розвитку. 
П'ятий крок - процедура коригування отриманих комплексних показників оцінки конкурентоспроможності робочої сили за групами з урахуванням ваги їхнього впливу, встановленої на основі експертного опитування на першому етапі.

Шостий крок передбачає обчислення загального інтегрального показника конкурентоспроможності робочої сили та контроль якості отриманих результатів оцінки.

На третьому етапі методики (аналітичному) здійснюється інтерпретація даних проведених розрахунків і формування кінцевого аналітичного результату дослідження. Цей етап охоплює процедуру рейтингування регіонів за значенням інтегрального показника конкурентоспроможності робочої сили регіону та за окремими групами чинників. Для цього використовується метод рівних інтервалів, згідно з яким розмір інтервалу визначається за формулою:

$$
h=\frac{Z_{i j \max }-Z_{i j \min }}{k},
$$

де $h$ - інтервал групування; $k$ - кількість груп.

На основі визначеної методики було сформовано п'ять основних груп: регіони з високим рівнем конкурентоспроможності; регіони з рівнем, вищим за середній; регіони з середнім рівнем; регіони з рівнем, нижчим за середній; регіони з низьким рівнем.

На цьому етапі результати розрахунків також використовуються для глибинного аналізу наявних регіональних відмінностей у рівнях окремих комплексних показників конкурентоспроможності робочої сили, визначення ключових ознак регіонів і формування агрегованих висновків.

Заключним кроком аналітичного етапу методики є картографування отриманої інтегральної оцінки конкурентоспроможності робочої сили регіонів, яка дає змогу візуалізувати інтерпретацію результатів дослідження.

Четвертий етап (заключний) передбачає доопрацювання результатів аналізу, отриманих на третьому етапі, визначення на його основі актуальних проблем у сфері конкурентоспроможності робочої сили та характерних особливостей їх прояву в групах регіонів. Виявлені проблеми є основою для розробляння пропозицій щодо покращення рівня конкурентоспроможності робочої сили з урахуванням визначених прогалин у розвитку тієї чи іншої компоненти.

Висновки та перспективи подалыших досліджень. Управління конкурентоспроможністю робочої сили має базуватися на об'єктивних результатах просторово-часового оцінювання процесів іiі відтворення. Ураховуючи, що на сьогодні особливості й розбіжності регіонів за умовами формування та реалізації конкурентоспроможності робочої сили практично не розкриті, а також невідомо, наскільки рівень конкурентоспроможності кожного конкретного регіону відповідає регіональній спеціалізації та вимогам стратегічних цілей соціально-економічного розвитку, вважаємо, що запропонована методика може стати надійним інструментом для обгрунтування управлінських рішень у цій сфері. Циклічність процесу оцінювання конкурентоспроможності робочої сили, що є також однією з переваг пропонованої методики, створює можливості для проведення моніторингових досліджень у цій сфері з метою розробки практичних рекомендацій з нарощування конкурентних переваг регіонів. Перспективні дослідження у цьому напрямі будуть пов'язані з оцінюванням конкурентоспроможності робочої сили регіонів України у динаміці та з розроблянням практичних рекомендацій, пов'язаних з процесами їі формування та реалізації. 


\section{ЛІТЕРАТУРА}

1. Кравцевич С.В., Озерникова Т.Г. Измерение и оценка конкурентоспособности работника на рынке труда // Современная конкуренция. - 2008. - № 4. - С. 97-108.

2. Семикіна М.В., Смірнов О.О. Конкурентоспроможність персоналу підприємства: теорія і практика регулювання. - Кіровоград: КОД, 2008. - 208 с.

3. Hibbard D.R., Buhrmester D. Competitiveness, gender, and adjustment among Adolescents // Sex Roles. - 2010. - Vol. 63, Iss. 5-6. - P. 412-424.

4. Monsaas J., Engelhard G. Home Environment and the Competitiveness of Highly Accomplished Individuals in Four Talent Fields // Developmental Psychology. - 1990. - № 26 (2). - P. 264-268. https://doi.org 10.1037/0012-1649.26.2.264

5. Rastogi P.N. Knowledge management and intellectual capital - the new virtuous reality of competitiveness // Human System Management. - 2000. - Vol. 19, № 1. - P. 39-48.

6. Горнастаева Н.В. Исследование и оценка конкурентоспособности работников на внутрифирменных рынках труда: региональный срез // Вестник АГТУ. Серия: Экономика. - 2017. № 1. - C. 31-42. - https://doi.org 10.24143/2073-5537-2017-1-31-42

7. Грішнова О., Шпирко О. Конкурентоспроможність персоналу підприємства: критерії визначення та показники вимірювання // Україна: аспекти праці. - 2004. - № 3. - С. 3-9.

8. Петрова I.Л. Сегментація ринку праці: теорія і практика регулювання / Ін-т економіки, управління та господарського права. - Київ. 1997. - 298 с.

9. Фатхутдинов Р.А. Стратегический маркетинг. 3-е изд. - Санкт-Петербург: Питер, 2003. $347 \mathrm{c}$.

10. Цветкова I.I. Підвищення конкурентоспроможності персоналу підприємства: дис. ... канд. екон. наук: спец. 08.00.04 «економіка та управління підприємствами (підприємства машинобудівної та металургійної галузей)». - Сімферополь, 2007. - 250 с.

11. Labour market transitions of young women and men in Ukraine: Results of the 2013 and 2015 school-to-work transition surveys / Libanova E. et al.; Work4Youth Publication Series No. 41.- Geneva: International Labour Office, 2015. - 105 p.

12. Lisogor L. Competitiveness of labour force in Ukraine: formation and realization under conditions of innovative changes // Demography and social economy. - 2018. - № 3 (34). - P. 135-147. - https:// doi.org/10.15407/dse2018.03.135

13. Oulton $N$. Workforce Skills and Export Competitiveness // Acquiring Skills: Market Failures, Their Symptoms and Policy Responses / Booth A.L., Snower D.J. (Eds.). - New York: Cambridge University Press, 1996. - P. 199-232.

14. Perez J.R., De Pablos P.O. Knowledge management and organizational competitiveness: A framework for human capital analysis // Journal of Knowledge Management. - 2003. - № 7 (3). -P. 82-91. https://doi.org10.1108/13673270310485640

15. Ратніков Д.Г. Підвищення конкурентоспроможності трудового потенціалу найманих працівників в Україні в умовах глобалізації: автореф. дис.... канд. екон. наук: спец. 08.00.07 «демографія, економіка праці, соціальна економіка і політика». - Київ, 2010. - 24 с.

16. Семикіна $A$ B. Науково-методичні основи оцінювання конкурентоспроможності людського капіталу [Електронний ресурс]. - Режим доступу: http://ir.kneu.edu.ua/handle/2010/6128 (дата звернення: 28.02.2019).

\section{REFERENCES}

1. Kravtsevich, S.V., \& Ozernikova, T.H. (2008). Izmerenie i otsenka konkurentosposobnosti rabotnika na rynke truda [Measurement and assessment of the competitiveness of workers in the labor market]. Sovremennaia konkurentsiia - Journal of Modern Competition, 2(8), 97-108 [in Russian].

2. Semykina, M.V., \& Smirnov, O.O. (2008). Konkurentospromozhnist personalu pidpryiemstva: teoriia $i$ praktyka rehuliuvannia [Personnel Competitiveness: Theory and Practice of Regulation]. Kirovohrad: KOD [in Ukrainian].

3. Hibbard, D.R., \& Buhrmester, D. (2010). Competitiveness, Gender and Adjustment Among Adolescents. Sex Roles, 63, 412-424. 
4. Monsaas, J.A., \& Engelhard, G. (1990). Home Environment and the Competitiveness of Highly Accomplished Individuals in Four Talent Fields. Developmental Psychology, 26 (2), 246-268. https://doi. org/10.1037/0012-1649.26.2.264

5. Rastogi, P.N. (2000) Knowledge Management and Intellectual Capital - the New Virtuous Reality of Competitiveness. Human Systems Management, Vol. 19, 1, 39-48.

6. Gornastaeva, N.V. (2017). Issledovanie i otsenka konkurentosposobnosti rabotnikov na vnutrifirmennykh rynkakh truda: rehyonalnyi srez [Research and assessment of workers' competitiveness at intrafirm labour markets: a regional cut]. Vestnik AHTU. Seriia: Ekonomika - Vestnik of Astrakhan State Technical University. Series: Economics, 1, 31-42 https://doi.org/10.24143/2073-5537-2017-1-31-42[in Russian].

7. Grishnova, O., Shpyrko O. (2004). Konkurentospromozhnist personalu pidpryiemstva: kryterii vyznachennia ta pokaznyky vymiriuvannia [Competitiveness of the personnel of the enterprise: criteria of determination and indicators of measurement]. Ukraina: aspekty pratsi - Ukraine: aspects of labor, 3, 3-9 [in Ukrainian].

8. Petrova, I.L. (1997). Sehmentatsiia rynku pratsi: teoriia i praktyka rehuliuvannia [Segmentation of the labor market: the theory and practice of regulation]. Kyiv: Instityt ekonomiky, upravlinnia ta hospodarskoho prava [in Ukrainian].

9. Fatkhutdinov, R.A. (2003). Stratehicheskii marketinh [Strategic Marketing]. (3d ed.). Saint Petersburg: Pyter [in Russian].

10. Tsvetkova, I.I. (2007). Pidvyshchennia konkurentospromozhnosti personalu pidpryiemstva [Increasing the competitiveness of the company's staff]. Extended abstract of candidate's thesis. Simferopol [in Ukrainian].

11. Libanova, E., Cymbal, A., Lisogor, L., \& Iarosh, O. (2015). Labour market transitions of young women and men in Ukraine: Results of the 2013 and 2015 school-to-work transition surveys. Work4Youth Publication Series № 41. Geneva, International Labour Office.

12. Lisogor, L. (2018). Competitiveness of labour force in Ukraine: formation and realization under conditions of innovative changes. Demohrafiia ta sotsialna ekonomika - Demography and social economy, 3 (34), 135-147. https://doi.org/10.15407/dse2018.03.135

13. Oulton, N. (1996). Workforce Skills and Export Competitiveness. Acquiring Skills: Market Failures, Their Symptoms and Policy Responses. A.L. Booth, D.J. Snower (Eds.). New York: Cambridge University Press.

14. Perez, J. R., \& De Pablos, P.O. (2003). Knowledge management and organizational competitiveness: A framework for human capital analysis. Journal of Knowledge Management, 7 (3), 82-91. https://doi. org/ 10.1108/13673270310485640.

15. Ratnikov, D.H. (2010). Pidvyshchennia konkurentospromozhnosti trudovoho potentsialu naimanykh pratsivnykiv $v$ Ukraini $v$ umovakh hlobalizatsii [Increasing the competitiveness of labor potential of hired workers in Ukraine in the conditions of globalization]. Extended abstract of candidate's thesis. Kyiv [in Ukrainian].

16. Semykina, A.V. (2014). Naukovo-metodychni osnovy otsiniuvannia konkurentospromozhnosti liudskoho kapitalu [Scientific and methodological basis of evaluation of competitiveness of human capital]. Retrieved from http://ir.kneu.edu.ua/handle/2010/6128 [in Ukrainian].

Стаття надійшла до редакції журналу 26.04.2019. 


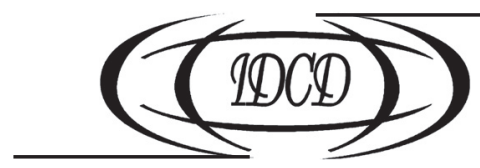

https://doi.org/10.15407/dse2019.02.178

УДК 519.7

JEL CLASSIFICATION: J11, J23, J24

\section{І.Л. ТАТОМИР}

канд. екон. наук., доц. каф. економіки та менеджменту

Дрогобицький державний педагогічний

університет імені Івана Франка

82100, Україна, м. Дрогобич, вул. Стрийська, 3

E-mail: Tatomur@gmail.com

ORCID 0000-0002-3274-7083

\section{ЗАЙНЯТІСТЬ ТА ОСВІТНЯ ПОЛІТИКА В ЕПОХУ ШТУЧНОГО ІНТЕЛЕКТУ Й РОБОТОТЕХНІКИ}

Мета статті - розглянути результати впливу використання штучного інтелекту на зайнятість населення та зміну професійних розподілів, обгрунтувати роль освіти у цих процесах та запропонувати иляхи мінімізації негативних наслідків ризиків цих процесів для національного ринку праці. Проаналізовано песимістичні та оптимістичні прогнози економістів щодо подальшої ролі штучного інтелекту у процесах автоматизації. Обгрунтовано вплив сучасних мегатрендів на глобальний ринок праці, визначено сфери, які зазнають найбільшого впливу робототехніки. Запропоновано напрями модернізаціі системи освіти на загальнодержавному рівні з метою забезпечення конкурентоспроможності робочої сили та їі швидкої адаптації до змін попиту та пропозиції на ринку праці. Мова йде про реорганізацію системи освіти з обов'язковим упровадженням у навчальні плани дисциплін IT-характеру, підтримання ініціатив з популяризації курсів Coursera, Edx, Udemy, Udasity та інших провайдерів. Це дасть змогу навчати українських студентів за світовими інноваційними програмами, збільшити кількість навчальних закладів за професійно-технічним спрямуванням та їх популярність серед молоді, впроваджувати активні системи отримання освіти безспосередньо на виробництві. Рекомендовано створювати профільні інститути та кафедри штучного інтелекту, робототехніки і машинознавства, які б тісно співпрацювали зі школами і приватними технохабами для підвищення рівня підготовки студентів, запровадження стипендій для обдарованої молоді та викладачів, які займаються дослідженнями у сфері штучного інтелекту.

Ключові слова: штучний інтелект, професії-«пенсіонери», щільність робототехніки, клас непотрібних людей, атлас професій.

\section{И.Л. Татомир}

канд. экон. н., доц. каф. экономики и менеджмента

Дрогобычский государственный педагогический

университет имени Ивана Франко

82100, Украина, г. Дрогобыч, ул. Стрыйская, 3

E-mail: Tatomur@gmail.com

ORCID 0000-0002-3274-7083 


\title{
ЗАНЯТОСТЬ И ОБРАЗОВАТЕЛЬНАЯ ПОЛИТИКА \\ В ЭПОХУ ИСКУССТВЕННОГО ИНТЕЛЛЕКТА И РОБОТОТЕХНИКИ
}

Проанализированы пессимистичные и оптимистичные прогнозы экономистов о дальнейшей роли искусственного интеллекта в процессах автоматизации. Обосновано влияние современных мегатрендов на глобальный рынок труда и определены сферы, испытывающие наибольшее влияние робототехники. Предложены направления модернизации системы образования на общегосударственном уровне с иелью обеспечения конкурентоспособности рабочей силы и ее быстрой адаптации к изменениям спроса и предложения на рынке труда. Речь идет о реорганизации системы начального образования с обязательным внедрением в учебные планы дисциплин ИТ-характера, поддержание инициатив по популяризации курсов Coursera, Edx, Udemy, Udasity и других провайдеров, что позволило бы обучать украинских студентов по мировым инновационным программам, увеличение количества учебных заведений по профессионально-техническим направлением, внедрение активных систем переобучения на производстве. Рекомендовано создание профильных институтов и кафедр искусственного интеллекта, робототехники и машиноведения, которые тесно сотрудничали бы со школами и частными технохабамии для повышения уровня подготовки студентов, организации стипендий для одаренной молодежи и преподавателей, занимающихся исследованиями в области искусственного интеллекта.

Ключевые слова: искусственный интеллект, профессии-«пенсионеры», плотность робототехники, класс ненужных людей, атлас профессий.

\author{
I. L. Tatomur \\ PhD in Economics, Associate Professor of departments of Economics and Management \\ Drohobych State Pedagogical University after Ivan Franko \\ 82100, Ukraine, Drohobych, Ivan Franko Str., 24 \\ E-mail: Tatomur@gmail.com \\ ORCID 0000-0002-3274-7083
}

\section{EMPLOYMENT AND EDUCATION POLICIES IN THE ERA OF ARTIFICIAL INTELLIGENCE AND ROBOTICS}

The paper analyzes the pessimistic and optimistic predictions of economists regarding the further role of artificial intelligence in automation processes. The influence of modern mega-trends on the global labor market is substantiated and the areas that are most affected by robotics are identified. The directions of modernization of the education system at the national level are proposed in order to ensure the competitiveness of the labor force and its rapid adaptation to changes in demand and supply in the labor market. It is a question of reorganizing the primary education system with the mandatory introduction of IT-disciplines into curricula, supporting initiatives to promote courses Coursera, Edx, Udemy, Udasity and other providers, which would allow Ukrainian students to study on world programs, increase the number of educational institutions according to the vocational and technical direction, the introduction of active retraining systems at work. An increase in state funding for research on artificial intelligence, the use of new combinations of public-private and academic cooperation, and the provision of various types of fiscal incentives to support technological start-ups, which are designed to improve production processes, are seen as needed. A digital education and cooperation with European universities in the field of artificial intelligence for a better exchange of work, informing young people and the academic community about the educational initiatives of technology companies, organizing summer schools for the study of IT technologies and the participation of our students and students in such projects for the border. It would be desirable to create specialized institutes and departments of artificial intelligence, robotics and machine science, which would closely cooperate with schools and private techno-architects, inviting to cooperation specialists who have experience in the IT industry, in the role of mentors, to help students in choosing interesting topics for educational projects, the introduction of scholarships for gifted youth and teachers engaged in research in the field of artificial intelligence.

Keywords: artificial intelligence, occupations retired, density of robotics, class of unnecessary people, atlas of professions.

Постановка проблеми та актуальність теми. Цифрова революція позначилась на професійно-кваліфікаційній структурі попиту та пропозиції на ринку праці та зумовила потребу у трансформації освітнього простору. Технологічні зміни призвели до того, 
що конкуренція за доступ до інноваційних технологій створила нові механізми експлуатації жителів країн, що розвиваються, та зниження рівня продуктивності їхньої праці. Цифровізація масиву даних, доповнена реальність, технології візуального трансферу та штучний інтелект (ШІ) змусили роботодавців переглянути традиційні підходи до підбору персоналу й організації робочих місць. У розвинутих країнах близько 40 \% із них уже відчули суттєві економічні переваги автоматизації робіт середньої складності і скорочення унаслідок цього частини працівників. Наприклад, оперування роботизованими системами коштує в США приблизно 10-20 доларів на годину, що є нижчим за середню заробітну платню у виробництві [1, с. 52]. Водночас використання і обслуговування нових технологій зумовило потребу підвищення рівня компетенції працівників, більшість з яких не готові до змін а над ринком праці нависла загроза поляризації структури зайнятості та появи професій-«пенсіонерів» ${ }^{1}$ і класу непотрібних людей².

Аналіз останніх досліджень та публікацій. Потенційна заміна працівників автоматизованими машинами привернула увагу науковців, роботодавців, політиків та експертів з цих питань. Наприклад, В. Мулявка (V. Mulyavska) [2] розглянула механізми експлуатації нових технологій, ризики автоматизації праці в суспільствах, що розвиваються, та перспективи для суспільств периферії. У роботах I. Новак (I. Novak) [3] показано, як ШІ, віртуальна реальність й великі дані трансформують обличчя ринку праці і визначено стратегічні орієнтири зайнятості.

Про оптимістичний і тривожний сценарій впливу ШІ на ринок праці і відповіді вищої освіти заговорили і зарубіжні дослідники Б. Сміт (В. Smith), Г. Шум (H. Shum) [1], Е. Бріньолфссон (Е. Brignolpson), Е. МакАфі (А. McAfee) [4], М. Форд (М. Ford) [5] та ін. Прихильники песимістичного сценарію розвитку [4, 5], оцінюючи маргінальний вплив використання ШІ на продуктивність праці, прогнозують масове безробіття, бідність і загострення соціальної напруги. На їхнє переконання, інтеграція технічних Cyber фізичних систем призведе до значної економії витрат на оплату праці та відмирання звичних професій, цикли яких скоротяться до 3-5 років. Як тільки для нової спеціальності буде створено алгоритм, виконання ії переходитиме до ро́бота. Освоєння всього невідомого стане новим кар’єрним викликом століття.

Прихильники оптимістичного сценарію [1, 2] не бачать приводу для паніки, адже економіка автоматизується безперервно: зникнення однієї частини робочих місць відбуватиметься одночасно з їх виникненням за іншими професійними та секторальними напрямками. Робота буде позбавлена рутинного характеру, стане цікавішою та творчою, формуватиметься не протистояння людей і машин, а їх взаємодопомога. Ця дискусія змушує заклади вищої освіти та підприємців шукати освітні рішення і таланти для нових цифрових ролей.

Економісти [3, 4, 5], наполягають на потребі розвитку цифрової грамотності, наданні престижнішого статусу професійно-технічній освіті й розробці адаптивних програм перенавчання для дорослого населення.

Мета статті - розглянути результати впливу використання штучного інтелекту на зайнятість населення та зміну професійних розподілів, обгрунтувати роль освіти у цих процесах й запропонувати шляхи мінімізації негативних наслідків формують цих процесів, для національного ринку праці.

\footnotetext{
${ }^{1}$ Професії пенсіонери - професії, що ризикують зникнути або ті, де працівники можуть бути замінені ро́ботами, комп'ютерними програмами та іншими автоматичними рішеннями.

2 Клас непотрібних людей - особи, які через небажання чи певні обставини не можуть опанувати затребувані вимогами часу професії.
} 
Новизною статті є обгрунтування можливих шляхів адаптації українського ринку праці до впровадження автоматизованих систем у виробничі процеси.

Методологія дослідження. Методологічною базою дослідження став аналіз підходів вітчизняних і зарубіжних учених до вивчення потенційного довгострокового впливу автоматизації на національний ринок праці. Для визначення технічного потенціалу автоматизації світової економіки різних країн застосовано методи порівняльного аналізу, дані міжнародної консалтингової компанії McKinsey, торговопромислової асоціації робототехнічних галузей $(R I A)$, а також міжнародних звітів про майбутнє робочих місць для наочної зміни «атласу професій»³.

Виклад основного матеріалу. Нижче описано нові мега тренди, які змінили характер праці.

Великі дані, штучний інтелект та Інтернет речей; демографічні зміни; глобалізація і поляризація професійної структури допомогли зробити нестандартні завдання автоматизованими, змінивши характер діяльності більшості країн. У результаті деякі з них почали переживати «передчасну деіндустріалізацію». Ризик автоматизації зайнятості виявився найвищим у країнах із середнім рівнем доходу, де вимоги до роботи є менш складними, пізнавальними, творчими та міжособистісними. 3 найбільшим ризиком техногенного безробіття, частково через залежність від виробничих робочих місць, стикнулися Литва, Греція, Туреччина, Словаччина. Багатші країни (Норвегія, США та країни Південно-Східної Азіі) легше і швидше адаптувалися до змін через можливість постійного доступу до нових технологій. Тому найгірші умови склалися для працівників з середнім рівнем оплати праці та неповною вищою освітою. Так, у США майже 3 млн осіб працюють як офісні службовці, дуже вразливі до автоматизації. Переважна більшість - жінки, середній вік яких становить 43,5 роки, а середня зарплата - трохи більше 30 тис. доларів на рік. Менше п’ятої частини мають ступінь бакалавра. Якщо вони не зможуть отримати нові навички, додаткову освіту або кращі повноваження, то не зможуть і зберегти сучасний рівень життя [5, с. 79]. На думку експертів, саме низькокваліфіковані працівники нестимуть основний тягар втрат. Їх надлишок стане істотною загрозою для країн, що розвиваються. Питання їх інтеграції в структурно складний ринок праці залежатиме від попиту іноземних держав і соціальної системи безпеки, адже праця мігрантів обходиться роботодавцям поки що дешевше, ніж виробництво, експлуатація та обслуговування роботів.

Однак чимало науковців погоджуються, що більшість високоосвіченого населення даремно почувається в безпеці. Для ШІ період, коли людина повинна навчитися певному предмету, не є релевантним критерієм. Всі види робіт рутинного характеру можуть виконувати інтелектуальні машини. Навіть для високооплачуваних посад, для яких потрібне багаторічне навчання та дипломи про вищу освіту, часто можна знайти багато звичайних замін. Фахівці китайського інтернет-гіганта Tencent впевнені, що ро́боти здатні і на творчу працю. Нещодавно компанія представила світу ро́бота-журналіста, який всього за одну хвилину написав статтю про стан фінансового ринку [2]. У 2018 р. світ побачив перших ро́ботів, які вміють малювати картини, брати участь у судових процесах як адвокати, ставити діагнози пацієнтам тощо.

Демографічні зміни призвели до зниження частки працездатного населення в одних країнах (-8 \% в Японії, $-23 \%$ в Італії і Німеччині, $-21 \%$ в Китаї) і зростання в інших (+41\% в Саудівській Аравії, $+33 \%$ в Індіï, $+27 \%$ в Австралії, $+26 \%$ у Мексиці і Аргентині) [6, с. 5], спричинивши суттєвий перерозподіл праці і ресурсів між

\footnotetext{
3 «Атлас професій» - експертна дорожня карта професійного розвитку на найближчі десятиліття.
} 
Загальні обсяги робіт, які можна автоматизувати шляхом адаптації до пропонованих технологій

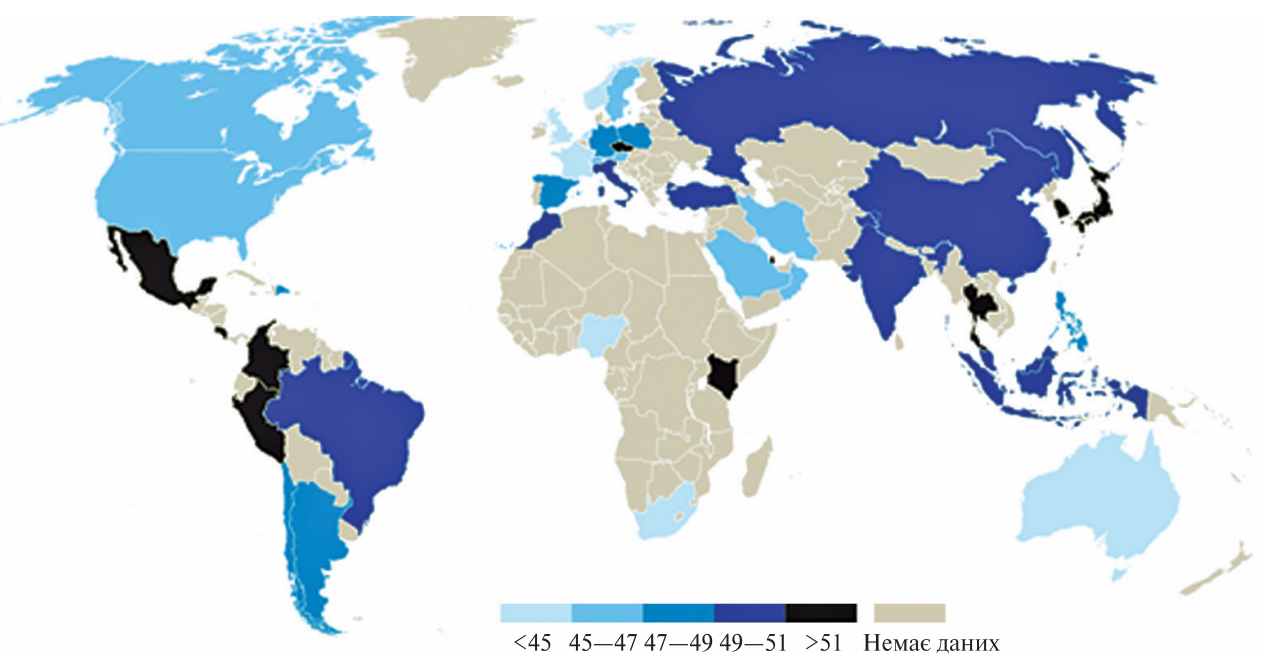

Заробітна плата пов'язана 3 технічною автоматичною діяльністю, трлн дол. США

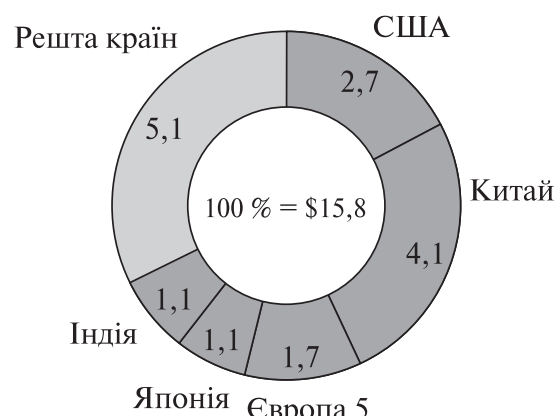

Японія Європа 5
Робота пов'язана $з$ технічною автоматичною діяльністю, млн дол. США

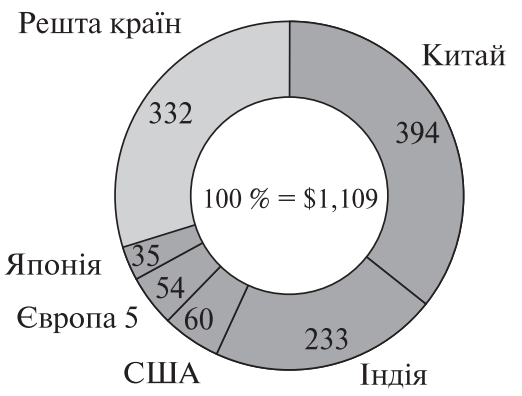

Потенціал автоматизації, \% Японія

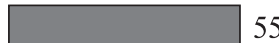

Індія

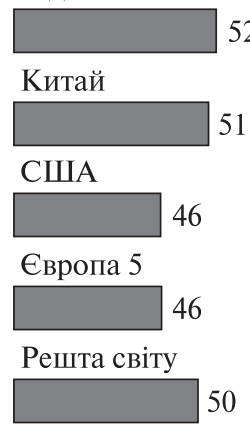

Рис. 1. Технічний потенціал автоматизації світової економіки в різних країнах

Примітка. Європа 5: Франція, Німеччина, Італія, Іспанія, Велика Британія.

Джерело: дані McKinsey \& Company [7, c. 7].

секторами та професіями. Країни з населенням, що старіє, почали активніше використовувати у виробничих процесах технології, а держави з молодою і збільшуваною робочою силою - потенціал демографічного дивіденду. Яскравим прикладом може слугувати Японія, де висока частка населення старшого віку і суворі закони в галузі трудової міграції змушують підприємців все більше використовувати ро́бототехніку, прискорюючи процес автоматизації.

Глобалізація зробила ринки праці більш взаємопов'язаними та сприяла прискореному темпу поширення технологій з використанням систем ШІ.

Поляризація професійної структури між високо- і низькокваліфікованими робочими місцями вплинула на нерівність розподілу доходів. 
Таблиця 1. Країни за часткою робочих місць з можливими високими темпами автоматизації для п'яти провідних галузей

\begin{tabular}{|c|c|c|c|c|c|}
\hline \multirow[t]{2}{*}{ Країна } & \multicolumn{5}{|c|}{$\begin{array}{c}\text { Частка робочих місць з можливими високими темпами автоматизації } \\
\text { для провідних галузей }\end{array}$} \\
\hline & $\begin{array}{l}\text { Виробни- } \\
\text { цтво, \% }\end{array}$ & $\begin{array}{l}\text { Оптова та роз- } \\
\text { дрібна торгівля, \% }\end{array}$ & $\begin{array}{l}\text { Здоров'я людини і } \\
\text { соціальна робота, \% }\end{array}$ & $\begin{array}{l}\text { Осві- } \\
\text { та, } \%\end{array}$ & $\begin{array}{c}\text { Будів- } \\
\text { ництво, \% }\end{array}$ \\
\hline Словаччина & 58 & 43 & 34 & 14 & 42 \\
\hline Словенія & 57 & 35 & 31 & 13 & 53 \\
\hline Литва & 55 & 39 & 27 & 26 & 58 \\
\hline Чехія & 55 & 33 & 38 & 10 & 36 \\
\hline Італія & 55 & 35 & 29 & 17 & 44 \\
\hline США & 53 & 51 & 28 & 12 & 34 \\
\hline Франція & 53 & 41 & 29 & 17 & 41 \\
\hline Німеччина & 43 & 49 & 24 & 9 & 39 \\
\hline Австрія & 48 & 37 & 26 & 9 & 51 \\
\hline Іспанія & 45 & 35 & 26 & 8 & 42 \\
\hline Польща & 50 & 31 & 21 & 9 & 48 \\
\hline Туреччина & 45 & 26 & 36 & 8 & 40 \\
\hline Ірландія & 50 & 39 & 17 & 7 & 33 \\
\hline Нідерланди & 46 & 35 & 24 & 7 & 36 \\
\hline Велика Британія & 45 & 42 & 18 & 8 & 23 \\
\hline Бельгія & 45 & 28 & 19 & 10 & 43 \\
\hline Данія & 46 & 33 & 17 & 9 & 44 \\
\hline Ізраїль & 42 & 34 & 17 & 8 & 42 \\
\hline Сінгапур & 33 & 38 & 19 & 9 & 26 \\
\hline Норвегія & 33 & 34 & 16 & 6 & 35 \\
\hline Швеція & 45 & 26 & 22 & 4 & 28 \\
\hline Японія & 32 & 27 & 6 & 10 & 29 \\
\hline Греція & 35 & 23 & 20 & 3 & 25 \\
\hline Фінляндія & 41 & 22 & 9 & 4 & 35 \\
\hline Північна Корея & 31 & 24 & 12 & 6 & 31 \\
\hline
\end{tabular}

Джерело: складено автором на основі [8].

За оцінками експертів Оксфордського університету, які спеціалізуються на машинознавстві, машини замінять приблизно 47 \% наших робочих місць протягом двох наступних десятиліть, що призведе до зростання кількості та питомої ваги без робітного та економічно неактивного населення. У США автоматизація знищить приблизно 9,1 млн робочих місць до 2025 року. Очікувана кількість робочих місць, які потенційно можуть зникнути в Японії, становитиме 55 \%, в Індії 52, у Китаї 51 та у Сполучених Штатах 46 (рис. 1) [7, с. 5]. Нерівномірність автоматизованості робочих місць у різних країнах ілюструють рис. 1 та табл. 1. 


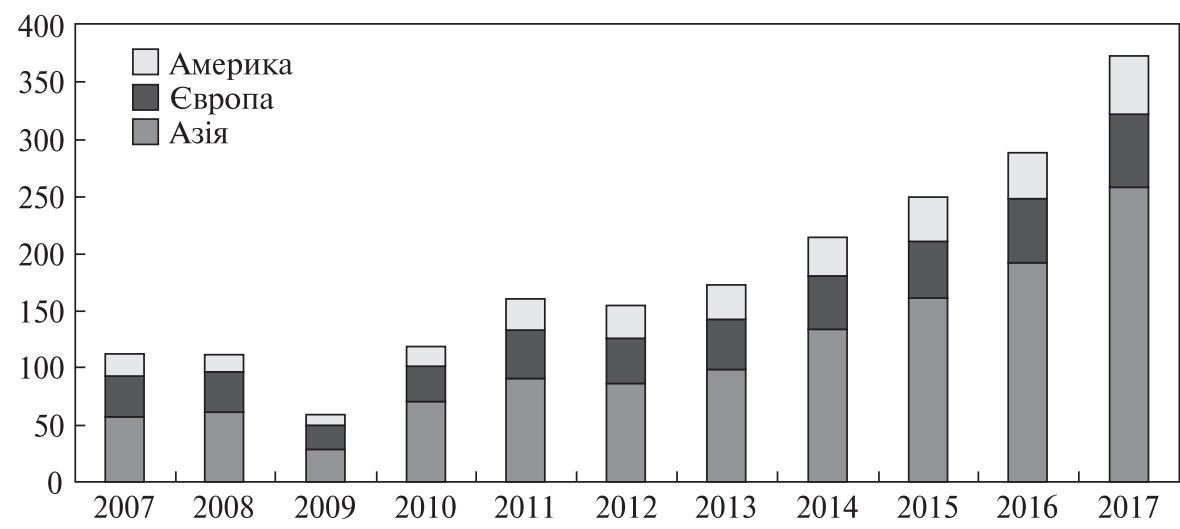

Рис. 2. Динаміка річних обсягів постачання промислових ро́ботів за регіонами світу, тис. одиниць

Джерело: побудовано автором на основі [9].

Дані Асоціації ро́бототехнічних виробників (RIA) [9], однієї з найбільших організацій, що займаються діяльністю в сфері автоматизованої роботи в Північній Америці, показують, наскільки поширені ро́боти можуть бути на робочому місці завтра. Рекорди з постачання робототехніки у всьому світі становив промисловий сектор: 294312 одиниць роботів 2016 року були відправлені клієнтам, що на $16 \%$ більше ніж з 2015. У 2017 році іх кількість досягла 380550 одиниць, що на $29 \%$ більше, ніж у попередньому (рис. 2). Безумовним лідером тут є країни Азії, зокрема Японія, яка лише у 2016 р. експортувала роботів для промислового сектору на суму 1,6 млрд дол. більше за п'ять найбільших експортерів (Німеччина, Франція, Італія, США, Південна Корея).

«Щільність робототехніки» як співвідношення роботів та людей, зайнятих у промисловості, визначає Міжнародна федерація робототехніки (IFR). Найвищий показник очікувано мають країни, які найактивніше продукують робототехніку (табл. 2). Угорі переліку IFR поставила Південну Корею, яка зуміла зберегти свій найвищий рейтинг з 2010 р. завдяки високому темпу зростання автоматизованих моделей. Наступний - Сінгапур, який закріпив за собою назву «успішного новатора робототехніки». Ще у п’ятірці лідерів - Німеччина, Японія та Швеція, які інтенсивно використовують основну частину роботів в електротехнічній, електронній та автомобільній промисловості. Найнижчий рівень «щільності робототехніки» притаманний Індії, Філіппінам і РФ, де на 10 тисяч робочих припадають три роботи.

Високий рівень «щільності робототехніки» доводить і той факт, що у країнах Азії з'являються повністю роботизовані виробництва. Так, у серпні 2015 р. у китайському місті Дунгуань відкрилася перша в історії роботизована фабрика з виробництва компонентів для стільникових телефонів. Власник фабрики компанія Changying Precision Technology замінила 650 співробітників на 60 роботизованих рук, тепер конвеєри працюють безперервно [11].

Негативні наслідки роботизації та автоматизації будуть відчуватися нерівномірно за професіями та сферами діяльності. Кращі робочі місця майбутнього потрапляють до одного сегмента технологічного обслуговування (рис. 3). Вчені-футурологи у «атлас професій» майбутнього включають такі види діяльності: сіті-фермер, проектувальник домашніх роботів, інформаційний стиліст, IT-генетик, експерт з майбутнього дитини, $I T$-медик тощо. Про існування таких фахів раніше годі було й подумати. 
Таблиця 2. Країни з найбільшою щільністю робототехніки, кількість промислових ро́ботів на 10 тис. виробничих працівників, 2016

\begin{tabular}{|c|c|c|c|}
\hline Країна & $\begin{array}{l}\text { Кількість промислових } \\
\text { ро́ботів на } 10 \text { тис. ви- } \\
\text { робничих працівників }\end{array}$ & Країна & $\begin{array}{c}\text { Кількість промислових } \\
\text { ро́ботів на } 10 \text { тис. вироб- } \\
\text { ничих працівників }\end{array}$ \\
\hline Південна Корея & 631 & Нідерланди & 153 \\
\hline Сінгапур & 488 & Канада & 145 \\
\hline Німеччина & 309 & Австрія & 144 \\
\hline Японія & 303 & Фінляндія & 138 \\
\hline Швеція & 223 & Словенія & 137 \\
\hline Данія & 211 & Словаччина & 135 \\
\hline США & 189 & Франція & 132 \\
\hline Італія & 185 & Швейцарія & 128 \\
\hline Бельгія & 184 & Чехія & 101 \\
\hline Тайвань & 177 & Австралія & 83 \\
\hline Іспанія & 160 & & \\
\hline
\end{tabular}

Джерело: складено за даними [10, с. 62].

Наприклад, цього року мережа LinkedIn оголосила вакансію на посаду тьютера для нейронної мережі - фахівця з різнопланового навчання ШІ. 2017 року порівняно з 2015 число користувачів LinkedIn, що додають навички в сфері Ш у своїх профілях, зросло на 190 \%. Це навички, необхідні для створення технологій Ш, які включають досвід у таких сферах, як нейронна мережа, глибоке вивчення та машинне навчання [13]. Затребувані математики, програмісти, компетентні статисти та фахівці з «кодування». Цінуватимуться так звані «універсальні солдати», особи, які володіють знаннями відразу в декількох галузях, добре знають свою роботу, не бояться виконувати складні завдання і регулярно покращують власні знання.

За даними Світового Економічного форуму, до 2030 року можуть зникнути або значно трансформуватись професії бухгалтера, копірайтера, бібліотекаря, юристаконсультанта, журналіста, перекладача, турагента, співробітників бек-офісів, сфери транспорту і логістики. Серед робітничих професій до категорії незатребуваних належатимуть охоронці, листоноші, оператори call-центрів, швеї, машинні оператори, гірники тощо. Така тенденція призведе до утворення класу непотрібних людей, частка яких у найближчому майбутньому збільшиться до 35-37 \% населення, а в деяких країнах - до 40 \%. Зараз у США налічується 10-12 \% непотрібних людей, в Ізраїлі - 8-9, в Південній Кореї, де існує культ роботи, - 1-2 \% [14].

За прогнозами економістів, до 2020 року середня заробітна плата у секторі ро́бототехніки збільшиться щонайменше на $60 \%$, однак більше третини наявних робочих місць залишатимуться вакантними через брак кваліфікованих працівників [15]. Міжнародні IT-гіганти Google, Facebook і Apple готові платити від 300 тис. дол. США на рік розробникам штучного інтелекту за умови, що вони є професіоналами в своїй галузі. Загалом річний оклад розробників ШІ може досягти 1 млн дол. США [16].

Ураховуючи попит на нові професії та невизначеність у традиційних секторах економіки через технічні зміни, актуалізується пошук нових освітніх рішень. Най- 


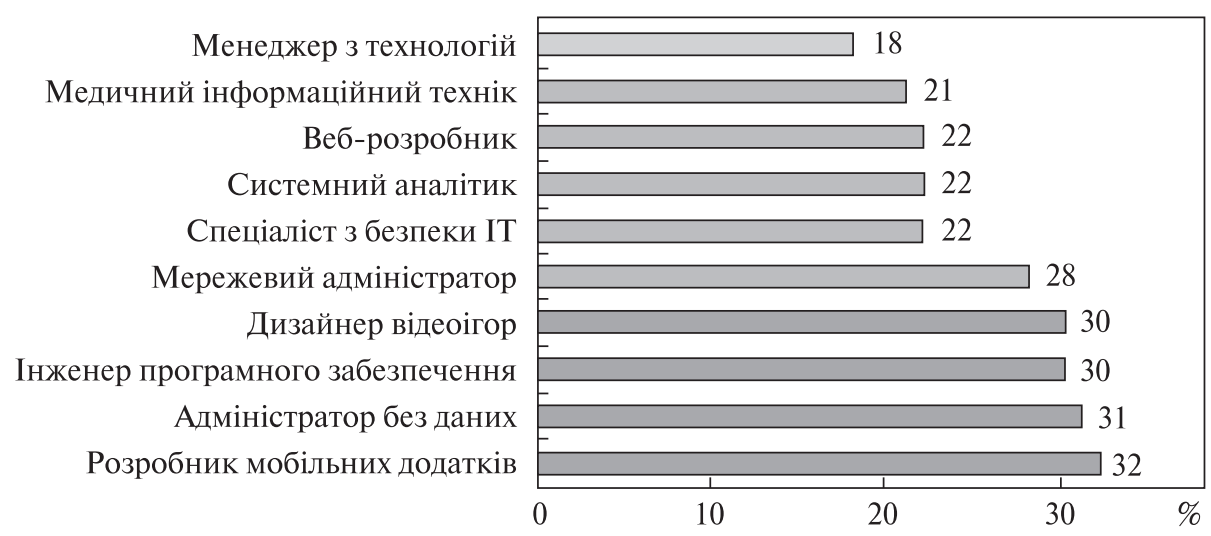

Рис. 3. Топ-10 професій майбутнього

Джерело: побудовано на основі даних [12].

кращу освіту надають країни, які впровадили обчислювальне мислення у початковій та середній школі. Студенти майбутнього повинні знати цю мову, навіть якщо вони оберуть будь-яку іншу галузь науки. Показовими у цьому відношенні є Японія, Китай та Ізраїль, де у шкільних програмах особливу увагу приділено вивченню інженерних технологій. Міністерства освіти цих країн дозволяють експериментувати з новими технологіями у класах з метою підготовки молоді, для якої робота з ШІ повинна стати запорукою їх майбутнього працевлаштування. Починаючи з 2019 р. уряд Японії пропонує впровадити вивчення програмування, а Китаю - курси з ШІ в початковій та середній школі. У ізраїльських школах учні, окрім стандартних дисциплін, слухають лекції про технології, IT-проекти, можливості їх реалізації та практичну цінність. До освітнього процесу адміністрація закладів залучає успішних стартаперів, керівників компаній і бізнесменів,У школах існують технологічні лабораторії з $3 D$-принтерами, ро́ботами, розумними дошками, що полегшує молоді адаптацію до технологічних нововведень. Особливу увагу уряди країн усе більше приділяють професійній технічній освіті, асигнуючи значні кошти у діяльність і зростання нових навчальних професійних закладів. Безумовним лідером тут є Китай з найбільшою в світі системою професійної освіти - 12300 коледжів, що пропонують близько 100000 спеціальностей [17]. Важливе значення для того, щоб люди могли пристосовуватись до нових технологій та ролей, матиме навчання протягом усього життя. Завдяки появі масових відкритих онлайн-курсів $(M B O K)^{4}$ та Інтернет-навчальних центрів (Coursera, Codeacademy, Big Data University ma edX Microsoft), де викладачами є професори і практики, успішні в тій чи іншій професії, якісна освіта стане ще доступнішою у кожному куточку світу. Найбільш затребуваними стануть проекти, за допомогою яких споживачі мають можливість швидко отримати нову кваліфікацію та конкретні навички, які згодом можна буде вдало конвертувати у дохід. Для прикладу, це можуть бути онлайн-курси, де навчають програмуванню, курси інтернет-маркетингу, створенню мобільних додатків та інтернет-магазинів тощо. Бум на віддалене навчання першочергово прослідковується серед людей, що вже певний період пропрацювали в професії і знають, які навички роботи й знання їм найбільше потрібні.

\footnotetext{
${ }^{4}$ МВOK - навчальні курси, розміщені онлайн і розраховані на всіх зацікавлених користувачів, що мають доступ до Інтернет, незалежно від віку, національності чи країни проживання.
} 
Технічні фірми з усього світу вживають заходів, щоб допомогти забезпечити майбутнє своїх нинішніх працівників. Хороший приклад - програма Amazon's Career Choice, яка заохочує співробітників до навчання навичкам майбутнього працевлаштування. HR експериментує з навчальними технологіями та хакатонами, щоб працівники постійно навчалися. Розширення ринку ділової освіти посилило і формування корпоративних навчальних інституцій - академій, інститутів, навчальних центрів тощо, діяльність яких має стратегічний характер, пов'язаний із бізнес-завданнями у сфері формування культури організації, кадрового резерву, оцінки ефективності персоналу та інвестицій, вкладених у його розвиток.

Намагається не відставати від технологічних новацій і український ринок праці. Україна, на жаль, не увійшла до переліку 40 країн, що використовують роботів у виробництві з показником 1 ро́бот на 20 тис. працівників (середньосвітовий показник - 74 ро́боти на 10 тис. осіб) [9] і займає 43 позицію серед 126 держав за розвитком інновацій згідно з індексом Блумберга. Український ринок робототехніки умовно можна розділити на два напрями: споживчий, де спостерігається стійкий попит на роботів-безпілотників і роботів-прибиральників, та промисловий - на якому щорічна реалізація роботів не перевищує кілька десятків, що свідчить про початковий попит промисловців на цю продукцію. Серед найбільших компаній-інтеграторів промислових ро́ботів і автоматизованих систем у виробничий процес можемо виокремити ТОВ «НВФ «Техвагонмаш» (м. Кременчук), АвтоЗАЗ (м. Запоріжжя), ТОВ «Центроспав-Україна» (м. Київ), ТОВ «Навко-Тех» (м. Київ) та ін. Перспективними напрямами для співпраці з іноземними компаніями експерти називають робототехніку, пов'язану з транспортом та логістикою, де українські виробники пропонують власні проекти. Типовими їх прикладами є ДК «Укроборонпром», який конструює техніку для оборонного комплексу, Drone. $U A$, що займається розробкою технологій для аграрної сфери, енергетики, геодезії і топографії, KNN Systems - компанія, що проектує рішення з роботизації процесів зварювання, фрезерування, плазмового різання і палетизації, компанія «Стандарт-ПАК», яка розробляє самохідні платформи, саморушні навантажувачі та ро́боти-буксири, запорізька компанія Інфоком ЛТД, що спеціалізується на безпілотних автомобілях, а також ряд інших компаній. Крім того, в Україні успішно функціонує декілька виробничих лабораторій у Дніпрі, Києві та Одесі - LabSeven, Ultimate Robotics, Mechatronics ROBOT Laboratory, Noosphere Engineering School, які працюють над комерційними замовленнями щодо реалізації роботизованих проектів у різних секторах економіки.

Ро́боти перестають бути просто технологічними цікавинками для українців. Найбільші вигоди від можливого впровадження автоматизованих систем отримає передовсім військовий сектор, використовуючи сучасні наземні роботизовані комплекси, наприклад, для розвідки. У найближчому майбутньому роботизовані пристрої зможуть вплинути і на українську медицину: це пристрої, які доповнять можливості хірурга, кіберпротези та біонічні лінзи. Враховуючи те, що технологічного оновлення потребує аграрний сектор, застосування високотехнологічних сервісів дасть змогу провадити моніторинг стану полів у реальному часі, виконувати автоматичне розрізнення культурних рослин і бур'янів, мінімізувати використання важкої людської фізичної праці. Від широкого асортименту інтегрованих рішень для інтелектуального управління виробництвом вигоди повинен отримати і промисловий сектор. Використання робототехніки та автоматизації має допомогти в морській розвідці нафти і газу, що може суттєво позначитися на ціні палива. 
Таблиця 3. Ризики та нові можливості, пов'язані з активізацією впровадження автоматизованих систем

\begin{tabular}{|c|c|c|}
\hline Роботодавці & Працівники & Держава \\
\hline \multicolumn{3}{|c|}{ Ризики } \\
\hline $\begin{array}{l}\text { МВОК - навчальні курси, роз- } \\
\text { міщені онлайн і розраховані на } \\
\text { всіх зацікавлених користувачів, } \\
\text { що мають доступ до Інтернет, } \\
\text { незалежно від віку, національ- } \\
\text { ності чи країни проживання }\end{array}$ & $\begin{array}{l}\text { Зростання потреби у перенавчан- } \\
\text { ні персоналу; } \\
\text { недостатньо висока надійність } \\
\text { роботизованих комплексів; } \\
\text { відсутність позитивного еконо- } \\
\text { мічного ефекту; } \\
\text { надання машинам певної вико- } \\
\text { навчої самостійності; } \\
\text { надмірне покладання на точність } \\
\text { та безвідмовність роботизованих } \\
\text { машин; } \\
\text { складність адаптувати роботи- } \\
\text { зовані комплекси для невеликих } \\
\text { підприємств }\end{array}$ & $\begin{array}{l}\text { Ручне управління поступово } \\
\text { втрачатиме значення на користь } \\
\text { технічних засобів; } \\
\text { невідповідність рівня підготовки й } \\
\text { брак потрібних навичок для роботи } \\
\text { на нових робочих місцях; } \\
\text { робота потребуватиме творчого та } \\
\text { критичного мислення; } \\
\text { вивільнення певної частини праців- } \\
\text { ників та виникнення «технологіч- } \\
\text { ного безробіття»; } \\
\text { нерентабельність автоматизації } \\
\text { дешевої робочої сили; } \\
\text { виведення відносин найму на новий } \\
\text { рівень; } \\
\text { поширення різних видів прекарної } \\
\text { зайнятості; } \\
\text { послаблення ролі профспілок та } \\
\text { соціального захисту; } \\
\text { зниження фізичної та соціальної } \\
\text { активності людей; } \\
\text { збільшення соціального поділу на } \\
\text { професійні касти; } \\
\text { зниження вартості технологій при- } \\
\text { зведе до того, що автоматизація і } \\
\text { компютеризація стануть вигідні- } \\
\text { шими за людську працю; } \\
\text { виникнення проблеми соціального } \\
\text { захисту в умовах можливого масо- } \\
\text { вого скорочення працівників } \\
\text { у наслідок упровадження роботизо- } \\
\text { ваної техніки }\end{array}$ \\
\hline \multicolumn{3}{|c|}{ Нові можливості } \\
\hline $\begin{array}{l}\text { Підвищення ефективності } \\
\text { виробництва і скорочення } \\
\text { витрат на утримання персо- } \\
\text { налу; } \\
\text { можуть одночасно виконувати } \\
\text { ряд завдань різної складності; } \\
\text { збільшення обсягів випуску } \\
\text { продукції та забезпечення } \\
\text { вищої рентабельності } \\
\text { інвестицій; } \\
\text { створення ефективної системи } \\
\text { контролю якості продукції } \\
\text { й зниження виробничих витрат } \\
\text { від браку; } \\
\text { автоматизовані системи } \\
\text { здатні працювати цілодобово } \\
\text { з незначними перервами; } \\
\text { розвиток технологій підвищу- } \\
\text { ватиме конкурентоспромож- } \\
\text { ність підприємства }\end{array}$ & $\begin{array}{l}\text { Надання технологічної } \\
\text { допомоги працівникам; } \\
\text { можуть виконувати роботу, яка } \\
\text { є надто складною або } \\
\text { небезпечною для життя людини; } \\
\text { підштовхуватимуть працівників } \\
\text { до підвищення рівня профе-- } \\
\text { сійних навичок та опанування } \\
\text { знаннями у суміжних галузях, що } \\
\text { сприятиме збільшенню фінансо- } \\
\text { вих надходжень }\end{array}$ & $\begin{array}{l}\text { Забезпечать фундаментальне при- } \\
\text { скорення науково-технологічних } \\
\text { досліджень; } \\
\text { використання новітніх технологій } \\
\text { стимулюватиме створення нових } \\
\text { робочих місць; } \\
\text { покликані заповнити брак трудових } \\
\text { ресурсів за умов незбалансовано- } \\
\text { го попиту та пропозиції на ринку } \\
\text { праці, старіння населення (старіння } \\
\text { знань і несприйняття інновацій) та } \\
\text { значних міграційних потоків квалі- } \\
\text { фікованих кадрів }\end{array}$ \\
\hline
\end{tabular}

Джерело: складено автором. 
На жаль, український ринок праці змінюється з певним запізненням. Оскільки вартість робочої сили в Україні є набагато нижчою від вартості імпортних автоматизованих машин, про стрімке зникнення ряду професій говорити ще рано. У більшості розвинутих країн ряд автоматизованих операцій виконують роботи, а в Україні вони є найбільш затребуваними за кількістю розміщених вакансій: продавці-консультанти, касири, банківські клерки, перекладачі тощо. Типові ризики, з якими український ринок праці може стикнутися уже в найближчі роки, представлені у табл. 3.

3 огляду на означені ризики та нові можливості автоматизації, ми повинні не приваблювати інвесторів дешевою робочою силою, а модернізувати й підвищувати ефективність виробництва за рахунок розширення доступу до вищої освіти. Очікується, що українці, здатні працювати з машинами, матимуть вищі шанси на працевлаштування. 3 огляду на це, професійно-технічні навчальні заклади під час підготовки випускників повинні забезпечити їх навичками роботи з автоматизованими системами, адже робітничі професії ставатимуть технологічно складнішими. На жаль, в Україні кількість закладів професійно-технічної освіти з кожним роком скорочується: 736 у 2018 р. проти 1023 у 2005 р. Перепідготовки потребуватиме і доросле населення, яке повинно бути готовим до зміни професійних обов'язків. До підтримки інноваційних проектів активно долучаються стартапери і держава. Знаковою подією для України стало масове відкриття освітніх центрів з робототехніки для дорослих і дітей: Boteon (Одеса, Дніпро, Харків, Київ, є франчайзі у восьми інших містах); «Винахідник» (Бровари, Буча, Вінниця, Київ, Львів, Дніпро, Івано-Франківськ, Харків, Одеса); TechMaker (курс для програмістів, Київ) та інші. Є курси при IT-компаніях: Guru IT School при компанії ThinkMobiles (Ужгород); Basic Robotics and Programming при Infopulse (Київ).

У 2013 р. український ринок освіти анонсував відкриття першого $M B O K$ від «Університет онлайн» (КНУ), який зібрав понад 9000 зареєстрованих користувачів. У жовтні 2014 р. стартував ще один національний освітній онлайн-проект - Prometheus, який пропонує курси з основ ведення бізнесу, інформаційної безпеки, програмування, закінчивши які слухачі отримають сертифікат, що вже набуває професійної ваги на національному ринку праці. Формат $M B O K$ в Україні успішно використовують для викладання шкільних предметів. Започаткований у 2017 р. український освітній ресурс про нові технології The Future пояснює, як завдяки технологіям майбутнього змінюється наше життя вже сьогодні. Для вибору тем автори орієнтуються на актуальні технологічні тренди. Команда проекту готує матеріали для шкіл, а вчителі використовують їх на уроках інформатики. За підтримки Міністерства освіти і науки України цим проектом успішно користуються 350 шкіл. Переклад курсів англійською мовою дав змогу запропонувати проект на ринку Канади та ряду європейських держав.

Незважаючи на певні позитивні моменти, для того, щоб український ринок праці міг належним чином слідувати світовим тенденціям та мінімізувати негативні наслідки використання автоматизованих систем, необхідним буде впровадження в дію ряду заходів. Можливими джерелами їх забезпечення повинні стати відповідні нормативно-правові документи, які регламентуватимуть правові відносини щодо політики в галузі ШІ й розвитку ринку праці, меморандуми про партнерство та пакти про приєднання до міжнародних альянсів з ШІ, угоди про співпрацю між закладами вищої освіти (ЗВО) і підприємницьким сектором, відповідні дозвільні документи щодо створення нових організаційних структур у межах ЗВО й участь у різного роду технічних проектах, державні програми фінансової підтримки технологічних нововведень тощо. Поетапність заходів повинна бути такою. 
Уряду необхідно стимулювати розвиток та поширення технологій ШІ й робототехніки шляхом створення відповідних комітетів і робочих ініціативних рад, які б займалися розробкою плану дій з розвитку інновацій. Прикладом може слугувати Дослідницький центр штучного інтелекту при Національному інституті передових промислових наук та технологій (AIST) Японії, який діє з 2015 р., а також Міністерство ШІ у ОАЕ. Необхідно суттєво збільшити державне фінансування, пов'язане 3 дослідженням ШІ завдяки зобов'язанням стосовно збільшення витрат на НДДКР та лабораторій цифрової трансформації, створення промислових і інвестиційних фондів для стартапів ШІ, інвестування в мережу та інфраструктуру, державні закупівлі, пов'язаних з ШІ.

Налагодження міжнародної співпраці у питаннях огляду проблем та вироблення рекомендацій щодо політики в галузі ШІ й розвитку ринку праці. Доволі успішними $є$ ініціативи деяких держав і регіонів світу. Першим позитивним кроком стало включення України до числа учасників стратегічної програми Європейського Союзу Horizon 2020. Однак доцільним видається налагодження й розширення співпраці у цій царині з Ізраїлем, Китаєм, Південною Кореєю, які продукують високорозвинені технології. Надання різного роду фіскальних стимулів щодо підтримки технологічних стартапів для покращення процесів організації виробництва та створення нових робочих місць. В Індії, наприклад, держава увільняє фірми-розробники програмного забезпечення від сплати прибуткового податку протягом 10 років. Ізраїльська влада постійно знижує податки для IT-компаній, підтримує спеціальну програму «Технологічні теплиці», яка надає творцям стартапу потрібне обладнання, спеціалістів та іншу допомогу. При Міністерстві управління промисловості країни існує інноваційна колегія, яка займається фінансуванням стартапів за державні кошти, надає спеціальні гранти, розмір яких може становити декілька мільйонів доларів [18].

Створення науковцям можливостей для відвідування виставок і самітів 3 ро́ботобудування, де провідні розробники обговорюють перспективи розвитку індустрії та демонструють новинки свої здобутки промислової робототехніки, роботіврятувальників, роботів-слуг та ін. Найбільше таких ініціатив належить КНР.

Відкриття великими компаніями-розробниками власних лабораторій чи курсів підготовки при кафедрах найрейтинговіших 3ВО з технічними напрямами навчання (Київський національний університет імені Тараса Шевченка, Національний університет «Львівська політехніка», Національний технічний університет України «Київський політехнічний інститут імені Ігоря Сікорського», Дніпровський національний університет). Адже саме ці навчальні заклади, згідно з опитуванням асоціації IT Ukraine, закінчили близько 40 \% програмістів України. Це треба робити, щоб студенти після закінчення навчання могли ставати до роботи, а компаніям не довелося витрачати додаткові кошти для їх перенавчання.

Запрошення до співпраці фахівців, які мають досвід роботи в $I T$-галузі, у ролі менторів, для допомоги студентам у виборі цікавих тем для навчальних проектів, долученні та організації процесу розробки програмного продукту і представлення результатів під час захисту робіт. Подібного роду ініціативи уже два роки поспіль практикує кафедра систем ШІ Інституту комп'ютерних наук та IT Національного університету «Львівська політехніка» та Львівський IT Кластер.

Провести цифровізацію усіх навчальних закладів - від початкової школи до університетів. Саме таким шляхом пішла влада Китаю, оголосивши у 2017 р. план цифровізації навчальних закладів, відповідно до якого кошти, виділені на освітній сектор, повинні йти на перенавчання викладачів, упровадження класів і факультетів 
із програмування, робототехніки й ШІ, створення онлайн-платформ для індивідуального навчання, залучення інвесторів для переобладнання закладів освіти.

Міністерству освіти і науки України спільно з прогресивними представниками бізнесу варто визначити та укласти перелік затребуваних у майбутньому компетенцій, відповідно до яких треба розробляти нові навчальні курси. Збільшення кількості профільних інститутів і кафедр ШІ, робототехніки і машинознавства, які б тісно співпрацювали зі школами і приватними технохабами з метою залучення технологічних талантів до комплексного дослідження систем ШІ, результати яких впроваджувалися б у різних сферах. Це дасть змогу університетській освіті виконувати роль агента соціальних інновацій. Нині в Україні діє лише дві такі установи: Інститут проблем штучного інтелекту МОН України та НАН України, та Інститут інформатики і штучного інтелекту ДонНТУ.

Організація літніх шкіл з вивчення $I T$-технологій та участь наших школярів і студентів проектах за кордоном - на кшталт DataLab SummerCamp 2016 у Празі, Mitacs Globalink Research Internship Program у Канаді. Першопрохідцем в Україні стала Перша міжнародна весняна школа з верифікації та штучного інтелекту, яка відкрилась на базі Харківського національного університету радіоелектроніки у квітні 2018 р.

Нам необхідно наслідувати європейські практики щодо підтримки неформальної освіти, яка має готувати до швидких змін. Це давно підтримувана європейськими державами концепція освіти протягом життя у вигляді тренінгів, семінарів, масових відкритих онлайн-курсів тощо. Навчальним закладам треба підтримати ініціативи з упровадження у закладах вищої освіти курсів Coursera, Edx, Udemy, Udasity для навчання українських студентів за світовими програмами та розроблення власних онлайн-курсів. Основною перевагою українських $M B O K$ повинна стати орієнтація на інноваційні футуристичні напрями і спеціалізації, які дадуть змогу підготувати затребуваних ринком праці спеціалістів. Мова йде про популярні курси з машинного навчання і комп’ютерної графіки, ШІ, генної інженерії, розвитку біотехнологій і мов програмування тощо.

Запровадження стипендій для обдарованої молоді та академічної спільноти, які займаються дослідженнями у сфері ШІ. Так, уряд США запровадив стипендію Turing, щоб підтримати початкову когорту стипендіатів ШІ, а Китай запустив п'ятирічну університетську програму для навчання як мінімум 500 вчителів та 5000 студентів, що працюють над технологіями.

Необхідно краще інформувати молодь та академічну спільноту про освітні ініціативи технологічних компаній. Найбільшою їх кількістю відома компанія Google, яка 2018 року запустила безкоштовний курс Learn with Google AI, присвячений машинному навчанню. Це ресурс, за допомогою якого будь-хто може дізнатися про розвиток можливостей ШІ, свої поліпшити власні навички і застосовувати їх у щоденній практиці. Подібного роду ініціативи з 2016 р. просуває на український ринок освіти і IT-школа Samsung, намагаючись зацікавити старшокласників прогресивними професіями майбутнього. Ці проекти активно підтримує Інститутом модернізації змісту освіти в рамках концепції нової української школи. Державним і приватним ЗВО треба кооперуватися з європейськими університетами в сфері ШІ для кращого обміну напрацюваннями.

Висновки. Вирішити завдання автоматизації уряд країни зможе через реорганізацію системи освіти, ії цифровізацію, підтримання ініціатив з популяризації курсів глобальних провайдерів, упровадження активних систем дуальної та технологічної освіти. Необхідність долучення до урядових ініціатив корпоративного сектору пов'язана 3 можливістю отримання професійних навичок, які будуть затребувані футуристичними 
професіями та виведенню відносин найму на новий рівень. Нормативно-правова та фінансова підтримка уряду сприятимуть розв'язанню соціально-економічних проблем, динамічному розвитку пріоритетних галузей економіки, покращенню процесів організації виробництва й підготовці потрібних фахівців, установленню міри відповідальності за дотримання цільових показників щодо створення «цифрових» робочих місць, а використання нових комбінацій співпраці державно-приватних і наукових кіл - майбутньому технологічному лідерству країни.

\section{ЛІТЕРАТУРА}

1. Smith B., Shum H. The Future Computed Artificial Intelligence and its role in society.- Published by Microsoft Corporation Redmond, Washington. U.S.A., 2018. - 151 p.

2. Мулявка В. Нові технології і глобальна нерівність // СПІЛЬНЕ: журнал соціальної критики. -12 жовт. 2016 [Електронний ресурс] - Режим доступу: https://commons.com.ua/uk/novi-tehnologiyii-globalna-nerivnist/ (дата звернення: 18.12.2018).

3. Новак I. Стратегія зайнятості для України: якими мають бути орієнтири? // Дзеркало тижня: міжнародний громадський тижневик. - Вип. 43, 20 листоп. 2017 [Електронний ресурс] - Режим доступу: https://dt.ua/macrolevel/strategiya-zaynyatosti-dlya-ukrayini-yakimi-mayut-buti-oriyentiri260541 .html (дата звернення: 18.12.2018).

4. Бріньолфссон Е., МакАфі Е. Друга епоха машин. - K., Fund, 2016. - 236 p.

5. Форд М. Пришестя роботів. Техніка і загроза майбутнього безробіття / Пер. $з$ англ. В. Горбатька. - Київ: Наш формат, 2016. - 400 с.

6. Future of work and skills. $2^{\text {nd }}$ Meeting of the G20 Employment Working Group (15-17 February 2017). - Hamburg, Germany: Organisation for Economic Co-operation and Development (OECD), 2017. $-24 \mathrm{p}$.

7. A future that works: automation, employment, and productivity. Executive summary. - McKinsey \& Company, 2017. $-21 \mathrm{p}$.

8. Hawksworth J., Berriman R. Will robots really steal our jobs? An international analysis of the potential long term impact of automation. - PricewaterhouseCoopers LLP, 2018. - $44 \mathrm{p}$.

9. Robotic Industries Association (RIA) [Електронний ресурс]. - Режим доступу: https://www. automationworld.com/company/robotic-industries-association-ria (дата звернення: 22.11.2018).

10. Global Robotics Market 2018-2022. Report. - TechNavio, 2018. - 132 p.

11. Китай став найбільшим у світі споживачем промислових роботів - Асоціація українсько-китайського співробітництва. - 04.08.2017. [Електронний ресурс]. - Режим доступу: http://aucc. org.ua/uk/kitay-stav-naybilshim-u-sviti-spozhivachem-promislovih-robotiv/ (дата звернення 28.11. 2018).

12. The Future of Jobs Report 2018. Centre for the New Economy and Society. - Geneva: World Economic Forum, 2018. - $147 \mathrm{p}$.

13. Why India ranks among the top 3 countries in AI skills. [Електронний ресурс]. - Режим доступу: https://www.livemint.com/AI/u8hvUi7qObOLP7Shq4rB1M/Why-India-ranks-among-the-top-3countries-in-AI-skills.html (дата звернення: 09.11.2018)

14. Тривожне майбутнє: біохакери, космічні гіди та клас «непотрібних». - 27 липня 2017 [Електронний ресурс]. - Режим доступу: https://www.volynnews.com/news/society/tryvozhne-maybutnyebiokhakery-kosmichni-hidy-ta-klas-nepotribnykh/ (дата звернення: 08.10.2018)

15. Robots will destroy our jobs - and we're not ready for IT - Guardian News and Media Limited. - 2017 [Електронний ресурс]. - Режим доступу: https://www.theguardian.com/technology/2017/jan/11/ robots-jobs-employees-artificial-intelligence (Last accessed: 04.11.2018).

16. Kahn J. Sky-High Salaries Are the Weapons in the AI Talent War. - Bloomberg Businessweek, - 2018 [Електронний ресурс]. - Режим доступу: https://www.bloomberg.com/news/articles/2018-02-13/ in-the-war-for-ai-talent-sky-high-salaries-are-the-weapons (Дата звернення: 04.11.2018).

17. McAfee A., Brynjolfsson E. Machine, Platform, Crowd: Harnessing Our Digital Future. -W.W. Norton \& Company, 1 ed, 2017. -408 p. 
18. Друга IT-столиця світу. Як Ізраїль став одним із найбільших технологічних центрів планети // Expres.ua. - 2018. [Електронний ресурс]. - Режим доступу: https://expres.online/archive/news/ 2018/01/19/280984-druga-it-stolycya-svitu-izrayil-stav-odnym-naybilshyh-tehnologichnyh-centriv (дата звернення: 12.12.2018).

\section{REFERENCES}

1. Smith, B., Shum, H. (2018). The Future Computed Artificial Intelligence and its role in society. Published by Microsoft Corporation Redmond, Washington. U.S.A.

2. Muliavka V. (2016) Novi tekhnolohii i hlobalna nerivnist [New technologies and global inequality]. SPILNE: zhurnal sotsialnoi krytyky. Access mode: https://commons.com.ua/uk/novi-tehnologiyi-i-globalnanerivnist/ [in Ukrainian].

3. Novak I. (2017) Stratehiia zainiatosti dlia Ukrainy: yakymy maiut buty oriientyry? [Employment strategy for Ukraine: what should the benchmarks be?]. Dzerkalo tyzhnia: mizhnarodnyi hromadskyi tyzhnevyk. Access mode: https://dt.ua/macrolevel/strategiya-zaynyatosti-dlya-ukrayini-yakimi-mayut-butioriyentiri-260541_.html [in Ukrainian].

4. Brignolpson, E., McAfee, A. (2016). Druha epokha mashyn [Second era of cars]. K. Fund [in Ukrainian].

5. Ford, M. (2016). Pryshestia robotiv. Tekhnika i zahroza maibutnoho bezrobittia [The advent of robots. Technique and the threat of future unemployment]. Pereklad z anhliiskoi V. Horbatka. Kyiv: Nash format [in Ukrainian].

6. Future of work and skills. $2^{\text {nd }}$ Meeting of the G20 Employment Working Group (15-17 February 2017). Hamburg, Germany: Organisation for Economic Co-operation and Development.

7. A future that works: automation, employment, and productivity. Executive summary (2017). McKinsey \& Company.

8. Hawksworth, J., Berriman R. (2018). Will robots really steal our jobs? An international analysis of the potential long term impact of automation. Pricewater house Coopers LLP.

9. Robotic Industries Association (RIA) (2018). https://www.automationworld.com/company/roboticindustries-association-ria.

10. Global Robotics Market 2018-2022. Report (2018). TechNavio.

11. Kytai stav naibilshym u sviti spozhyvachem promyslovykh robotiv [China has become the world's largest consumer of industrial robots]. Asotsiatsiia ukrainsko-kytaiskoho spivrobitnytstva. http://aucc.org.ua/ uk/kitay-stav-naybilshim-u-sviti-spozhivachem-promislovih-robotiv/ [in Ukrainian].

12. The Future of Jobs Report 2018. Centre for the New Economy and Society (2018). Geneva: World Economic Forum.

13. Why India ranks among the top 3 countries in AI skills (2018). https://www.livemint.com/AI/ u8hvUi7qObOLP7Shq4rB1M/Why-India-ranks-among-the-top-3-countries-in-AI-skills.html.

14. Tryvozhne maibutnie: biokhakery, kosmichni hidy ta klas «nepotribnykh» [An alarming future: biohackers, space guides and a «unnecessary» class] (2017). https://www.volynnews.com/news/society/ tryvozhne-maybutnye-biokhakery-kosmichni-hidy-ta-klas-nepotribnykh/ [in Ukrainian].

15. Robots will destroy our jobs - and we're not ready for IT (2017). Guardian News and Media Limited. https://www.theguardian.com/technology/2017/jan/11/robots-jobs-employees-artificialintelligence.

16. Kahn J. (2017). Sky-High Salaries Are the Weapons in the AI Talent War. Bloomberg Businessweek. https://www.bloomberg.com/news/articles/2018-02-13/in-the-war-for-ai-talent-sky-high-salariesare-the-weapons

17. McAfee, A., Brynjolfsson, E. (2017). Machine, Platform, Crowd: Harnessing Our Digital Future. Publisher: W. W. Norton \& Company; 1 edition.

18. Druha IT-stolytsia svitu. Yak Izrail stav odnym iz naibilshykh tekhnolohichnykh tsentriv planet [The second IT capital of the world. How Israel became one of the largest technological centers of the planet] (2018). https://expres.online/archive/news/2018/01/19/280984-druga-it-stolycya-svitu-izrayil-stav-odnymnaybilshyh-tehnologichnyh-centriv [in Ukrainian].

Стаття надійшла до редакції журналу 18.12.2018. 


\section{кнИжковиЙ огЛяд}

\section{СОЦІАЛЬНА БЕЗПЕКА ЯК ІНТЕГРАЛЬНИЙ НАПРЯМ ДЕРЖАВНОГО РЕГУЛЮВАННЯ ПІДВИЩЕННЯ НАРОДНОГО ДОБРОБУТУ *}

Традиційна соціальна наука і усталений світогляд, де майже безроздільно панує віковий постулат про біо-соціальну природу людини, фіксує проблему соціального як основоположну системну підвалину розвитку людського суспільства. Тому дослідження соціального тренду у глобальному і національному вимірі $є$ постійно актуальним. Соціальні відносини досить швидкозмінні, але виявлення глибинної суті соціального дає змогу стверджувати, що головний вектор соціальних трансформацій зводиться до забезпечення безпеки життя людини, держави, людського суспільства. Особливо цей вектор світорозуміння загострюється в умовах нинішньої глобальної кризи, яка все більше актуалізує проблему реалізації імперативу виживання людства.

У цьому плані надзвичайно цікавою є монографія О.Г. Сидорчук «Соціальна безпека: державне регулювання та організаційно-економічне забезпечення», де викладена авторська концепція державного регулювання соціальної безпеки в Україні. Авторка виходить із того, що в загальному розумінні соціальна безпека розглядається як захищеність від невоєнних реальних і потенційних загроз суверенітету й територіальній цілісності держави, іiі демократичному конституційному ладу, правам і свободам людини, національним інтересам громадянина, соціуму та держави, що забезпечує розвиток демократії, добробут і безпечні умови життя (с. 51). При цьому наголошено, що соціальна безпека держави та суспільства повинна підпорядковуватися забезпеченню реалізації соціальної безпеки людини. Такий методологічний підхід уможливлює комплексне дослідження проблем соціальної безпеки у новому форматі постнекласичної людиномірної економічної науки, де особистість розглядається як свободовідповідальний творчий базовий суб'єкт усіх господарських перетворень, які насамперед повинні забезпечувати людині соціальну безпеку життя. Про це досить показово свідчить сама логіка авторського аналізу багаторівневої системи соціальної безпеки за вектором: соціальна безпека людини - соціальна безпека суспільства - соціальна безпека держави (розділ 2).

У монографії представлено розроблену авторкою ієрархічну модель інтегрального показника соціальної безпеки, виявлено основні чинники ії становлення з оцінкою резервів, а також ідентифіковано головні соціальні ризики та ризики економічної незахищеності за умови їх прояву і реалізації як чинників загроз соціальній безпеці суспільства. Надзвичайно важливо підкреслити, що така ієрархічна модель інтегрального показника соціальної безпеки відображає не кабінетно-теоретичні схеми,

\footnotetext{
* Рецензія на видання: СИДОРчУК О.Г. Соціальна безпека: державне регулювання та організаційно-економічне забезпечення / Львів. регіон. ін-т держ. управл. Нац. акад. держ. управл. при Президентові України. - Львів, 2018. - 492 c.
} 
відірвані від сучасних українських господарських реалій, вона базується на висновку, що в українському суспільстві загрози соціальній стабільності є значними. Це насамперед пов'язано з високими показниками загальної бідності населення країни, а також масовою бідністю зайнятих у сфері праці. Спрощення змісту соціально-трудових відносин у кризових умовах обернулося формуванням соціальних небезпек щодо оплати праці, зайнятості та довготривалого безробіття, а взагалі - значною деформацією ціннісних орієнтацій в українському суспільстві, втратою людського капіталу та трудового потенціалу країни, зростанням соціальної напруги, високою ймовірністю посилення політичних і соціальних ризиків і загроз.

У монографії висвітлено авторську методику вимірювання соціальної безпеки, методику і алгоритм визначення ризиків економічної незахищеності у старості, за умови захворювання, втрати роботи та працездатності, самотності та ін. Систематизовано чинники підвищення чи гальмування соціальної безпеки в Україні. Досить цілісно розглянуто проблеми розвитку інститутів громадянського суспільства, які стають одним із надзвичайно важливих пріоритетів та інструментів підвищення рівня соціальної безпеки особи та суспільства.

У цьому аспекті, з одного боку, зроблено висновок, що система державного управління в Україні не спрямована на врахування вагомої ролі інституцій громадянського суспільства як самодостатнього суб’єкта безпечних соціальних трансформацій. 3 іншого боку, розкрита актуальна необхідність розробки і забезпечення державного регулювання соціальної безпеки через визнання вагомим пріоритетом сучасного актикризового реформування. Це може досягатися організаційно-управлінськими, правовими, економічними, інформаційно-комунікативними, фінансовими, кадровими механізмами, що цілеспрямовано забезпечують підвищення рівня соціальної безпеки українського суспільства. У цьому плані держава через значне посилення своєї інтегральної функції неодирижизму мала б стати реальним диригентом для забезпечення симфонії у царині соціальної безпеки людини, суспільства, головних суб'єктів господарського антикризового розвитку.

Наукова цінність монографії пов’язана також із тим, що у ній глибоко змістовно викладено авторський проект Концепції забезпечення соціальної безпеки України, де подано загальні положення, принципи забезпечення та критерії досягнення соціальної безпеки країни, визначені реальні ії загрози, розроблені практичні рекомендації та заходи щодо реалізації основних напрямів забезпечення національної соціальної безпеки. Представлений проект містить усі необхідні структури концепції як нормативно-правового документа: мету, критерії досягнення, принципи, пріоритетні соціальні інтереси головних суб'єктів забезпечення соціальної безпеки, соціальні загрози, основні напрями та заходи, які б сприяли ефективній практичній реалізації Концепції заради підвищення загального добробуту українського народу.

3 огляду на викладене, можна кваліфікувати рецензовану монографію Сидорчук О.Г. «Соціальна безпека: державне регулювання та організаційно-економічне забезпечення» як комплексне самостійно виконане наукове дослідження, у якому органічно поєднано теоретичні засади і практичні рекомендації щодо розв'язання однієї з найбільш гострих суспільно-значущих проблем національного сьогодення - забезпечення високого рівня соціальної безпеки задля створення реальних умов зростання добробуту українського народу. Читачу надано можливість всебічно ознайомитися з найновішими фундаментальними науковими розробками у царині соціальної безпеки та сучасними проблемами іiі державного регулювання. 
Якщо ж говорити про майбутні поглиблені дослідження суті, багаторівневого змісту та розв'язання проблем соціальної безпеки в українському суспільстві, авторці доцільно буде акцентувати увагу на аналізі ролі та значення духовної безпеки, яка $€$ фундаментальною засадою забезпечення соціальної та національної безпеки. Виходячи з того, що сучасна соціально-трудова наука починає своє методологічне оновлення з визнання аксіоми про триіпостасну духовно-біо-соціальну природу людини (А.М. Колот), повинен змінюватися і формат соціальнобезпекових розмислів у руслі нової постнекласичної людиномірної економічної науки. Такий новий науковий формат передовсім має зосередитися на осмисленні й розробці національної відроджувальної стратегії духовно-ноосферно-сталого господарського розвитку, реалізація якої покликана створювати всебічні умови для людиномірних антикризових безпечних для життя господарських реформ. Перефразуючи відомий вислів Вудро Вільсона, питання полягає в тому, чи зуміємо ми зробити світ «безпечним для доброти», а не лише «для демократіі»?

Монографія заслуговує на значну увагу серед учених і практиків, що займаються актуальними проблемами публічного управління й економіки, представників громадських об'єднань, політичних і державних діячів.

Г.В. Задорожний, доктор економічних наук, професор, академік Академії економічних наук України, завідувач кафедри міжнародної економіки та світового господарства Харківського національного університету імені В.Н. Каразіна 


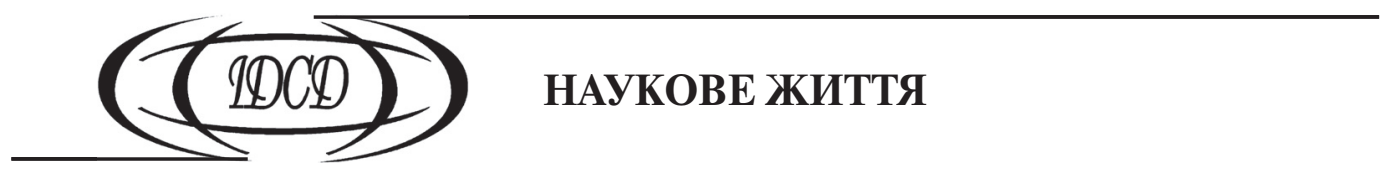

\section{СЛОВО ПРОЩАННЯ}

На 86-му році життя відійшла у вічність відомий демограф, кандидат економічних наук, цікава творча особистість

\section{ЛЮБОВ ВАСИЛІВНА ЧУЙКО}

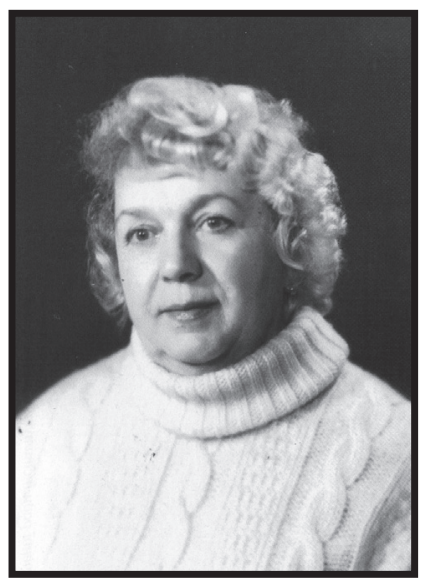

Любов Чуйко народилась 1 вересня 1933 року у Харкові, у робітничій сім'ї. 1958 року закінчила з відзнакою економічний факультет Харківського державного університету за спеціальністю «статистика» і 1963 року почала свій науковий шлях - вступила на навчання до аспірантури Інституту економіки АН УРСР, 1968 року захистила кандидатську дисертацію на тему «Шлюбність в Україні у післявоєнний період (статистичне дослідження)», а в 1978 одержала наукове звання старшого наукового співробітника за спеціальністю «економіка народонаселення і демографія».

Близько 50 років Любов Василівна присвятила науці демографії. У 1966 р. вона почала працювати у щойно створеному відділі демографії Інституту економіки АН УРСР, де, здолавши шлях від молодшого до провідного наукового співробітника, стала відомим фахівцем у царині демографічних і гендерних досліджень, спеціалізуючись на теоретичних і практичних наукових дослідженнях проблем шлюбу, сім'ї, праці і побуту жінок. У 2004-2006 рр. продовжила свою наукову діяльність у відділі демоекономіки Інституту демографії та соціальних досліджень НАН України.

Любов Чуйко була найвизначнішим українським сім'єзнавцем, гідно продовжувала і розвивала ідеї славетного українського демографа Ю.О. Корчака-Чепурківського, поруч із яким починала свій творчий шлях. Ї̈̈ вагомий внесок у розвиток демографічної теорії шлюбу та сім'ї, грунтовні розробки щодо демографічного та трудового потенціалу і структурно-функціональних трансформацій сім'ї широко знані не лише серед вітчизняних науковців, вони одержали визнання як у країнах пострадянського простору, так і далеко за його межами. Виконані за її керівництвом у 1970-1980-х роках вибіркові дослідження шлюбної ситуації та дітородної поведінки сімей були унікальними для України того часу. Широко відомі ії дослідження структурних і динамічних характеристик шлюбно-сімейної сфери у різні історичні 
періоди, від післявоєнних і до початку XXI століття, дослідження новітніх тенденцій розвитку інститутів шлюбу і сім’ї, їх причин і демографічних наслідків, проблем та ризиків життєдіяльності української сім’ї у широкому контексті: щодо шлюбної ситуації, дітородної активності, гендерної взаємодії, економічних проблем тощо. Свої фундаментальні наукові розробки вона завжди гармонійно поєднувала з пошуком напрямів, засобів і механізмів вирішення найактуальніших демографічних проблем, брала активну участь у розробці концептуальних засад, стратегії й системи конкретних заходів національної сімейної та молодіжної політики.

Любов Чуйко є автором майже 200 наукових і науково-популярних робот, а іiі монографія «Браки и разводы» («Шлюби і розлучення») відома всім, хто цікавиться сімейною проблематикою, і привернула пильну увагу якнайширшого кола фахівців на всьому пострадянському просторі. Її наукові здобутки є актуальними і нині.

Л.В. Чуйко була членом Міжнародного наукового союзу з вивчення населення (1990-2007), брала участь у проектах Представництва ООН в Україні, у численних міжнародних конференціях і форумах. Активно займалась науково-координаційною, лекторською і громадською діяльністю, була головою Ради жінок Інституту економіки НАН України (1979-2003), членом громадських жіночих організацій, зокрема Спілки жінок України та Києва.

Любов Василівна була не тільки науковцем, але і людиною високого інтелекту і культури, цікавою творчою особистістю, чарівною і мудрою жінкою. У 2017 році вона видала поетичну збірку «Віра, Надія, Любов. Крізь миті і роки. Поезія», де поєднала власні віршовані твори та авторські переклади творів поетів-класиків українською мовою.

Колектив Інституту демографії та соціальних досліджень імені М.В. Птухи НАН України збереже світлу пам'ять про видатного науковця і цікаву творчу особистість, фахівця і мудру жінку - Любов Василівну Чуйко. 


\title{
ПРАВИЛА ДЛЯ АВТОРІВ
}

\author{
детально висвітлено на сайті журналу https://www.dse.org.ua
}

До опублікування у фаховому журналі «Демографія та соціальна економіка» приймаються наукові праці, які ніколи не друкувалися раніше. Стаття має бути написана на актуальну тему, містити результати глибокого наукового дос-лідження, новизну та обгрунтування наукових висновків відповідно до мети статті (поставленого завдання). Публікація статей для авторів - без оплати.

Стаття, подана без дотримання вимог, опублікуванню не підлягає. Рукопис не повинен перевищувати обсяг 21 сторінки (разом з літературою, анотаціями) формату A4, набір тексту через 1,5 інтервали. Поля: всі - по 2 см, абзац - відступ на 1,27 см. Шрифт: Times New Roman, poзмip - 14, виконані на комп'ютері у редакторі Word for Windows (*.doc). Для публікації в науковому журналі статті подаються українською чи англійською мовами.

Разом із статтею автор повинен надати підписаний Ліцензійний договір на використання твору (форма розміщена на сайті журналу). ORCID.

Кожна стаття повинна мати коди УДК, JEL Classification, кожний автор - ідентифікатор

Стаття повинна складатися з таких розділів: постановка проблеми, актуальність обраної теми, новизна, аналіз останніх досліджень і публікацій, постановка мети і завдань, методи дослідження, виклад основного матеріалу дослідження і отриманих результатів, висновки і перспективи подальших досліджень у цьому напрямі. У кінці статті розташовують переліки посилань: Література, References.

Обсяг анотації украӥнською та англійською мовами - 300-400 слів (не менше 1800 знаків без пробілів).

Обов'язкові вимоги до анотацій. Вони повинні бути: інформативними (без загальних слів); структурованими (відображати послідовну логіку опису результатів у статті); змістовними (відображати основний зміст статті; описувати основні цілі дослідження; підсумовувати найбільш значущі результати); містити конкретизацію авторського внеску (що проаналізовано, розроблено, запропоновано, обгрунтовано, здійснено, визначено, виявлено, впроваджено тощо).

Авторська анотація має: містити пояснення, як було проведено дослідження, без методологічних деталей; не містити посилання та абревіатури.

Назви праць у списку літератури розміщують у порядку цитування в тексті.

Автор може робити посилання в Літературі на свої наукові твори, але тільки на одну роботу.

Матеріали, що публікуються в журналі, підлягають конфіденційному рецензуванню, кожна стаття отримує не менше двох рецензій. За потреби може застосовуватися додаткове незалежне конфіденційне рецензування.

Редакційна колегія журналу залишає за собою право рецензувати, редагувати, скорочувати (без змін позицій авторів) надані матеріали та здійснювати відбір статей. У разі негативної рецензії чи наявності суттєвих зауважень стаття може бути відхилена або направлена автору (авторам) на доопрацювання. Відхилені рукописи авторам не повертають. Рецензовані, доопрацьовані статті розглядає редакційна колегія журналу, рекомендує до друку Вчена рада Інституту.

Відповідальність за достовірність інформації, фактів та інших відомостей, посилань на нормативні акти, цитати, власні імена, а також правильність перекладу несуть автори публікації.

Матеріали, що публікуються в журналі, віддзеркалюють точку зору авторів, яка не завжди може збігатися з позицією редакційної колегії.

Термін подання статей до журналу:

- $\quad$ до першого номеру до 20 грудня (подання журналу до друку у березні наступного року);

- $\quad$ до другого номеру до 20 березня (подання журналу до друку у червні поточного року);

- $\quad$ до третього номеру до 20 травня (подання журналу до друку у вересні поточного року);

року).

До тексту статті обов'язково додається авторська довідка. 


\section{ПРОХОДЖЕННЯ РЕЦЕНЗУВАННЯ СТАТЕЙ У НАУКОВОМУ ЖУРНАЛІ «ДЕМОГРАФІЯ ТА СОЦІАЛЬНА ЕКОНОМІКА»}

I. Наукові статті, що надійшли та зареєствовані у редакції журналу, проходять рецензування, яке виконують висококваліфіковані фахівці з відповідних наукових напрямів. Вони мають наукові ступені доктора або кандидата наук, дослідження і публікації за відповідною спеціальністю та тематикою. За необхідністю голова редколегії журналу додатково залучає фахівців за відповідною спеціальністю. У разі виявлення різних позицій рецензентів і автора стаття направляється третьому рецензенту та додатково розглядається на засіданні редколегії журналу. Рецензентів запрошують до співпраці з конкретними матеріалами голова редколегії журналу та його заступники.

У журналі запроваджено двостороннє конфіденційне (сліпе) рецензування.

II. Рецензент повинен розглянути статтю протягом 10-12 робочих днів з моменту їі отримання та направити рецензію до редакції журналу особисто чи електронною поштою. У випадку неможливості прорецензувати статтю (наприклад, через конфлікт інтересів) рецензент надсилає мотивовану відмову протягом трьох днів із дня отримання листа від редакції журналу. Строки рецензування в кожному випадку визначаються з урахуванням необхідності забезпечення умов для максимально оперативної публікації статті та не можуть перевищувати двох тижнів.

III. Рецензія має однозначно характеризувати теоретичну або прикладну значущість дослідження, співвідносити назву статті, мету статті і висновки автора з відомими науковими концепціями. Необхідним елементом рецензії є оцінка рецензентом особистого внеску автора статті в рішення розглянутої проблеми, іiі актуальності та новизни. Доцільно відзначити в рецензії відповідність стилю, логіки й доступності викладу наукового характеру матеріалу, повноту і достатність розкриття теми у викладі статті, в розширених анотаціях, оцінити достовірність і обгрунтованість висновків автора, повноту, достатність і актуальність цитувань, здійснених автором, дотримання ним наукової етики, зокрема відсутність у рецензованій статті плагіату.

Висновок рецензента, укладений за запропонованою редакцією формою, повинен бути підписаний рецензентом із зазначенням місця роботи, посади, наукового ступеня, вченого звання, дати завершення рецензування.

IV. У разі отримання рецензії з зауваженнями та рекомендаціями, стаття із анонімною копією рецензії направляється авторам на доопрацювання.

Під час доопрацювання статей за зауваженнями рецензентів автор виділяє у доопрацьованому електронному варіанті статті змінений текст, додані речення, таблиці, рисунки чи інший доданий матеріал для оперативної перевірки рецензентом врахованих зауважень за наданими рецензіями.

Після доопрацювання автором (авторами) статті за зауваженнями, матеріали направляються рецензенту для перевірки внесених змін і доповнень.

Після отримання висновків рецензентів про придатність до опублікування доопрацьованих авторами статей редакційна колегія журналу ухвалює остаточне рішення щодо укладання змісту номерів журналу.

Вчена рада Інституту демографії та соціальних досліджень імені М.В. Птухи НАН України затверджує до друку та опублікування в мережі Інтернет кожен номер наукового журналу.

V. Оригінали рецензій зберігаються в редакції журналу два роки.

VI. За наявності критичних зауважень рецензента до статті по суті, але за загальної позитивної рекомендації, редколегія може віднести матеріал до розряду полемічних і друкувати статтю 3 позначкою «Наукова дискусія». 


\title{
ПРАВИЛА ДЛЯ АВТОРОВ
}

\author{
детально на сайте https://www.dse.org.ua
}

К опубликованию в специализированном журнале «Демография и социальная экономика» принимаются научные труды, которые никогда не печатались ранее. Статья должна быть написана на актуальную тему, содержать результаты глубокого научного исследования, новизну и обоснование научных выводов, соответствующих цели статьи (поставленного задания). Публикация статей для авторов - без оплаты.

Рукописи принимаются объемом до 21 страницы (с аннотациями и литературой) формата A4, набор текста 1,5 интервала. Поля все - по 2 см, абзац - оступ на 1,27 см. Шрифт: Times New Roman, размер - 14, выполненные на компьютере в редакторе Word for Windows (*.doc). Для опубликования в научном журнале статьи представляются на украинском или английском языках.

Вместе со статьей автор подает Лицензионный договор на использование произведения (форма размещена на сайте журнала).

Каждая статья должна иметь коды УДК, JEL Classification, каждый автор - идентификатор ORCID. Схема размещения аббревиатур, размеров шрифтов, интервалов, последовательность разделов, подразделов и др. детально освещена на сайте журнала.

Статья должна иметь такие необходмые разделы: постановка проблемы, актуальность выбранной темы, новизна, анализ последних исследований и публикаций, постановка цели и задач, методы исследования, изложение основного материала исследования и полученных результатов, выводы и перспективы дальнейших исследований в этом направлении, в конце статьи располагают списки использованных источников: Литература, References*.

Аннотации на украинском и английском языках - 300-400 слов (не менее 1800 знаков без пробелов).

Обязательные требования к аннотациям. Они должны быть: информативными (без общих слов); структурированными (отражать последовательную логику описания результатов в статье); содержательными (отражать основное содержание статьи; описывать основные цели исследования, наиболее значительные результаты; содержать конкретизацию авторского вклада (что проанализировано, предложено, разработано, обосновано, проведено, определено, выявлено, внедрено и т. д.); компактными.

Авторская аннотация должна содержать объяснения, как было проведено исследование, без методологических деталей, не содержать ссылок и аббревиатур.

Название источников литературы располагать следует в порядке упоминания в тексте.

Автор может делать ссылки в Литературе на свои научные труды, но только на одну работу.

Материалы, публикуемые в журнале, подлежат конфиденциальному рецензированию, каждая статья получает не менее двух рецензий. Для более объективной оценки научного содержания статей может применяться дополнительно независимое, конфиденциальное рецензирование (без указания фамилий авторов и рецензентов).

Редакционная коллегия журнала оставляет за собой право рецензировать, редактировать, сокращать (без изменений позиций авторов) и проводить отбор статей. При отрицательной рецензии или наличии существенных замечаний статья может быть отклонена или направлена автору (авторам) на доработку. Отклоненные рукописи авторам не возвращаются. Статья, представленная без соблюдения указанных требований, опубликованию не подлежит. Рецензированные, доработанные статьи рассматривает редакционная коллегия журнала, рекомендует к печати Ученый совет Института.

Ответственность за достоверность фактов и сведений, ссылок на нормативные акты, цитаты, имена, а также правильность перевода несут авторы публикации.

Материалы, публикуемые в журнале, отражают точку зрения авторов, не всегда могут совпадать с позицией редакционной коллегии.

Срок подачи статей в журнал:

- $\quad$ к первому номеру до 20 декабря (подача журнала в печать в марте следующего года);

- $\quad$ ко второму номеру до 20 марта (подача журнала в печать в июле текущего года);

- $\quad$ к третьему номеру до 20 мая (подача журнала в печать в сентябре текущего года);

- $\quad$ кетвертому номеру до 20 сентября (подача журнала в печать в декабре текущего года).

К тексту обязательно прилагается авторская справка. 


\section{ПРОХОЖДЕНИЕ РЕЦЕНЗИРОВАНИЯ СТАТЕЙ В НАУЧНОМ ЖУРНАЛЕ «ДЕМОГРАФИЯ И СОЦИАЛЬНАЯ ЭКОНОМИКА»}

I. Научные статьи, поступившие и зарегистрированные в редакции журнала, проходят рецензирование, выполняемое высококвалифицированными специалистами соответствующих научных направлений. Они имеют научные степени доктора или кандидата наук, исследования и публикации по соответствующей специальности и тематике. При необходимости глава редколлегии журнала привлекает дополнительно специалистов по соответствующей специальности, в случае выявления различных позиций рецензентов и автора статья направляется третьему рецензенту и дополнительно рассматривается на заседании редколлегии журнала. Рецензентов к сотрудничеству приглашают главный редактор журнала и его заместители.

В журнале принято двустороннее конфиденциальное (слепое) рецензирование.

II. Рецензент должен рассмотреть статью в течение 10-12 рабочих дней с момента ее получения и направить рецензию редакции журнала лично или по электронной почте. В случае невозможности прорецензировать статью (например, из-за конфликта интересов), рецензент направляет мотивированный отказ в течение трех дней со дня получения письма редакции журнала. Сроки рецензирования в каждом отдельном случае определяются с учетом необходимости обеспечения условий для максимально оперативной публикации статьи и не могут превышать двух недель.

III. Рецензия должна однозначно характеризовать теоретическую или прикладную значимость исследования, соотносить название статьи, цель статьи и выводы автора с существующими научными концепциями. Необходимым элементом рецензии является оценка рецензентом личного вклада автора статьи в решение рассматриваемой проблемы, ее актуальности и новизны. Целесообразно отметить в рецензии соответствие стиля, логики и доступности изложения научного характера материала, полноту и достаточность раскрытия темы в изложении статьи, в расширенных аннотациях, а также указать достоверность и обоснованность выводов автора, полноту, достаточность и актуальность цитирования, проведенного автором, соблюдение им научной этики, в частности отсутствие в рецензированной статье плагиата.

Заключение рецензента, составленное в соответствии с предложенной редакцией формой, должно быть подписано рецензентом с указанием его места работы, должности, ученой степени, научного звания, даты завершения рецензирования.

IV. В случае получения рецензии с замечаниями и/или предложениями, статья с анонимной копией рецензии направляется авторам на доработку.

При доработке статей в соответствии с замечаниями и рекомендациями рецензентов автор выделяет в доработанном электронном варианте статьи измененный текст, добавленные предложения, таблицы, рисунки или иной материал для оперативной проверки рецензентом учтенных замечаний по предоставленным рецензиям.

После доработки автором (авторами) статьи согласно замечаниям, материалы направляются рецензенту для проверки внесенных изменений и дополнений.

После получения заключения рецензентов о пригодности доработанных авторами статьей, редакционная коллегия журнала принимает окончательное решение относительно утверждения содержания номеров журнала.

Ученый совет Института демографии и социальных исследований имени М.В. Птухи НАН Украины утверждает к печати и публикации в сети Интернет каждый номер научного журнала.

V. Оригиналы рецензий, протоколы заседаний редакционной коллегии хранятся в редакции журнала два года.

VI. При наличии критических замечаний рецензентов к статье по сути, но при общей положительной рекомендации, редколлегия может отнести материал к разряду полемических и печатать статью с отметкой «Научная дискуссия». 


\title{
GUIDELINES FOR AUTHORS
}

\author{
is described at the web-site in details https://www.dse.org.ua
}

To be considered for a publication in the journal, only research papers that have never been published before are accepted. The article should be devoted to the relevant subjects, present the results of a thorough study, be characterized by innovations and scientific conclusions in accordance with article's goals (specified tasks). The publication is free of charge for the authors.

The length of accepted manuscripts should be 21 pages (including references and extended summaries) of A4 format, 1.5 spacing. All margins $-2 \mathrm{~cm}$, indent $-1.27 \mathrm{~cm}$, font: Times New Roman $14 \mathrm{pt}$ saved in Word for Windows (*.doc). The articles are accepted in Ukrainian or English.

The author should also sign the License Agreement to agree with publication in the Journal (the Form of Agreement is available at the web-site).

Every manuscript should be classified with UDC, JEL Classification Codes, each author is an ORCID identifier. The scheme of situation of abbreviations, font sizes, intervals, structure of paragraphs and sub-paragraphs, as well as references.

At the beginning of the article, authors' name and surname should be placed, as well as their academic degree and rank, position, affiliation, postal and electronic address, the publication's title, summary and the key words - in three languages.

The article should consist of the next structural components: description of the research problem, relevance of the theme, innovative character, analysis of the recent studies and publications, research methods, setting of the article's goal and tasks, the main findings of the study, conclusions and prospects of future studies in the field. The references are placed in the end of the article.

The Summary in Ukrainian and English should be within 300-400 words (not less than 1,800 printed signs).

Mandatory guidelines for the Summary: informing character (no general words); well-developed structure (successive logic of description of the article's findings should be assured); relevant (description of article's main contents; define the study's main tasks; summarize the key findings and their importance); detailed definition of the author's contribution (which positions are developed, proposed, defined, justified, made, revealed, etc.); compact character.

Author's summary should: explain the study's approaches, but without methodological details; provide no references and abbreviations.

The author can do the social work in Literature once for his own scientific work.

All manuscripts are subjects for internal and external review by the members of the

Editorial Board, and experts from the respective research fields. The Editorial Board should receive at least one external review and at least one internal review. To ensure the fair examination of scientific value of manuscript, an independent blind review can be used (without mentioning the names of authors and reviewers).

The Editorial Board has a privilege to review, edit, abridge (not changing author's opinion), and select the manuscripts. In case of a negative review or important remarks, the manuscript can be returned to the author (authors) for working out. Declined manuscripts should not be returned. The manuscripts submitted with no consideration of the mentioned requirements, cannot be published in the Journal. The reviewed manuscripts are examined by the Editorial Board of the Journal and recommended by the Scientific Council of the Institute.

The author is responsible for authenticity of the information, data, references, names and translation. The materials that are being published in the journal reflect the view of their authors, and not necessarily are agreeing with the position of Editorial Board.

Deadline for submission of articles to the journal:

- the first volume: $20^{\text {th }}$ of December (journal submission for publication in March of this year);

- the second volume: $20^{\text {th }}$ of March (journal submission for publication in July of this year);

- the third volume: $20^{\text {th }}$ of May (journal submission for publication in September);

- the fourth volume: $20^{\text {th }}$ of September (journal submission for publication in December).

The manuscript should be attached with the author's reference. 


\section{THE PROCESS OF REVIEWING THE ARTICLES SUBMITTED TO THE SCIENTIFIC JOURNAL DEMOGRAPHY AND SOCIAL ECONOMY}

I. Academic papers submitted to the Editorial Office have to pass through the process of reviewing by highly qualified experts in the relevant research fields. The experts hold the academic degrees (Doctors of Science or Candidates of Science (PhD) and have experience in the related studies, as well as academic publications. In case of a need, the Chairman of the Editorial Board invites additional scientific experts. If authors' views significantly differ from the reviewer's views, the article is submitted to the third party reviewer, while it is also discussed at the meeting of the Editorial Board. The reviewers are invited by the Chairman of the Editorial Board and the Deputy Chairman.

The blind peer review of two experts is conducted for all papers.

II. The reviewer should work on the article within 10-12 business days since the date of receipt and submit his/her review to the Editorial Board in person or by e-mail. If the reviewer is unable to review this article (for example, due to a conflict of interest), he/she should send the motivated rejection within 3 days. The length of reviewing is identified individually in order to ensure the most expeditious publication of the article, but must not exceed two weeks.

III. The review should clearly indentify the theoretical or practical significance of the study, and estimate the links between the article's title, objectives and conclusions with the existing scientific concepts. The reviewer should evaluate author's personal contribution to the study of research problems, its relevance and novelty. It is purposeful to mention the conformity of style, logics and comprehensibility of the presentation of research findings, as well as completeness and adequacy of representation in the title and the extended abstracts. Authors' conclusions might be evaluated in terms of reliability and validity, as well as ethical considerations, including plagiarism.

The review should be based on the proposed form, signed by the reviewer with identifying his affiliation, position, academic degree and title, date of signing the review.

IV. In the review provides additional comments and suggestions for the author, the paper is sent to the author with a confidential review.

When finalizing

the articles with regard to the comments of reviewers, the author should mark the revised text, as well as amendments in the text, tables, figures and other additional information in order to enable the timely informing of the reviewer about the accepted suggestions.

After article's updating, the texts are sent to the reviewer to verify the accuracy of the revisions and amendments.

The final decision on publishing of the article is made by the Editorial Boars after receipt of the reviewer's conclusion.

Academic Council of the Ptoukha Institute of Demography and Social Studies of the National Academy of Sciences of Ukraine approve for publication and publication on the Internet of each issue of the scientific journal.

V. The original texts of reviews are kept in the Editorial Office of the Journal for two years.

VI. In case of the reviewer's multiple critical comments, but general positive recommendations for publishing, the article might be placed in the category of polemical studies and marked with the note "Scientific discussion". 